\title{
Characterising the Anthropocene: Ecological Degradation in Italian Twenty-First Century Literary Writing
}

by

\author{
Alessandro Macilenti \\ A thesis \\ submitted to the Victoria University of Wellington \\ in fulfilment of the \\ requirements for the degree of \\ Doctor of Philosophy \\ in Italian Literature. \\ Victoria University of Wellington
}

2015 



\begin{abstract}
The twenty-first century has witnessed the exacerbation of ecological issues that began to manifest themselves in the mid-twentieth century. It has become increasingly clear that the current environmental crisis poses an unprecedented existential threat to civilization as well as to Homo sapiens itself. Whereas the physical and social sciences have been defining the now inevitable transition to a different (and more inhospitable) Earth, the humanities have yet to assert their role as a transformative force within the context of global environmental change. Turning abstract issues into narrative form, literary writing can increase awareness of environmental issues as well as have a deep emotive influence on its readership. To showcase this type of writing as well as the methodological frameworks that best highlights the social and ethical relevance of such texts alongside their literary value, I have selected the following twenty-first century Italian literary works: Roberto Saviano's Gomorra, Kai Zen's Delta blues, Wu Ming's Previsioni del tempo, Simona Vinci's Rovina, Giancarlo di Cataldo's Fuoco!, Laura Pugno's Sirene, and Alessandra Montrucchio's E poi la sete, all published between 2006 and 2011. The main goal of this study is to demonstrate how these works offer an invaluable opportunity to communicate meaningfully and accessibly the discomforting truths of global environmental change, including ecomafia, waste trafficking, illegal building, arson, ozone depletion, global warming and the dysfunctional relationship between humanity and the biosphere.
\end{abstract}




\section{Contents}

1 Introduction 1

1.1 A Scientific Foundation for Environmentalism . . . . . . . . . . . 3

1.2 The Response So Far: Swimming Against the Tide . . . . . . . . . 6

1.3 A Brief History of Italian Environmental Activism . . . . . . . . . . 12

1.4 Environmental Literature in Italy $\ldots \ldots \ldots \ldots \ldots \ldots$

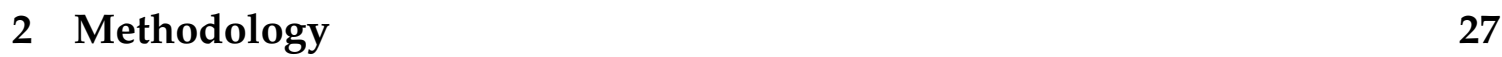

2.1 Exploring the Field . . . . . . . . . . . . . . . . . . . 27

2.2 Rationale for the Selection of Works $\ldots \ldots \ldots \ldots$

2.3 Literature Review . . . . . . . . . . . . . . . . . . . . . . . 30

$2.3 .1 \quad$ Cognitive Literary Theory $\ldots \ldots \ldots$

2.3 .2 Ecocriticism . . . . . . . . . . . . . . . . . . 34

2.4 Theoretical Approach . . . . . . . . . . . . . . . . . . . . 46

2.4 .1 The Premises of Cultural Hacking . . . . . . . . . . . 47

2.4 .2 The Tasks of Mourning. . . . . . . . . . . . . . . . . . 52

2.4 .3 Opening New Perspectives . . . . . . . . . . . . . . 60

2.4 .4 Moulding Moral Paradigms . . . . . . . . . . . . . . . 67

2.5 Conclusion . . . . . . . . . . . . . . . . . . . . . 70

3 Locality 1: Chemical Pollution 73

3.1 A Toxic Tour through "La terra dei fuochi" $\ldots \ldots$. . . . . . . 80

3.1.1 The Mechanisms of Gomorra . . . . . . . . . . . . . . . . . 82

3.1 .2 Saviano's Narrative Strategies . . . . . . . . . . . . . . . 90 
3.2 Violent Metaphors: Delta blues . . . . . . . . . . . . . . . . . . . 99

$3.2 .1 \quad$ A Delta of Intersecting Texts . . . . . . . . . . . . . 102

3.2 .2 Fast and Slow Violence. . . . . . . . . . . . . . . . . . . 109

3.2 .3 Zen Archery . . . . . . . . . . . . . . . . . . . . . 127

3.3 Previsioni del tempo . . . . . . . . . . . . . . . . . . . . . 130

3.3 .1 Criminal Midas . . . . . . . . . . . . . . . . . . . . . . . 134

3.3 .2 A Landscape of the Mind . . . . . . . . . . . . . . . 146

3.4 Conclusion . . . . . . . . . . . . . . . . . . . . 153

4 Locality 2: Changes in Land Use 155

$4.1 \quad$ A Look at Our Changing Landscapes. . . . . . . . . . . . . . . . . 155

4.1.1 Narrating Land Use Change in the Twentieth Century . . . 160

4.1 .2 The Foundations of Criminal Wealth . . . . . . . . . . . 163

$4.2 \quad$ A Story of Places and People: Rovina . . . . . . . . . . . . . . . . . 166

4.2 .1 The Structure of Ruin . . . . . . . . . . . . . . . . . . . . . . 169

$4.2 .2 \quad$ A Landscape of Denial . . . . . . . . . . . . . . . . . . . 173

4.3 Wild Passions and Wildfires: Fuoco! . . . . . . . . . . . . . . . . . 181

$4.3 .1 \quad$ A Burning Issue: Wildfires in Italy . . . . . . . . . . . . . 183

4.3 .2 Teenage Treehuggers and Adult Dolts . . . . . . . . . . . 187

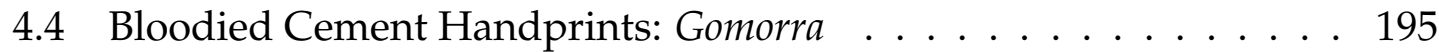

4.4 .1 The System . . . . . . . . . . . . . . . . . . . . . . . . . 196

4.4 .2 The Materiality of Cement. . . . . . . . . . . . . . . . . 204

4.5 Conclusion . . . . . . . . . . . . . . . . . . . . . 213

$\begin{array}{lll}5 & \text { Translocality } & 217\end{array}$

5.1 Transcending Political Frames . . . . . . . . . . . . . . . . . 218

5.2 Uncanny Hyperobjects: Sirene . . . . . . . . . . . . . . . . . . 220

5.2 .1 Imagining an Uncannily Imminent Future . . . . . . . . . 221

5.2 .2 Black Gods: Sirene's Hyperobjects . . . . . . . . . . . . . 234

5.3 A Climate of Fear: E poi la sete . . . . . . . . . . . . . . . . . . 244

5.3 .1 Literary Writing: The How and the Why . . . . . . . . . 245

5.3 .2 Envisioning Hyperobjects: Climate Fiction . . . . . . . . 247 
CONTENTS $\quad \mathrm{v}$

5.4 Conclusion . . . . . . . . . . . . . . . . 257

6 Conclusions 259

6.1 Reviewing Premises and Findings . . . . . . . . . . . . . . 259

6.2 Looking Forward: Future Directions . . . . . . . . . . . . . . . . 261

\begin{tabular}{|lll}
\hline Appendix A Intervista a Jadel Andreetto, Kai Zen & 267
\end{tabular}

\begin{tabular}{|ll|}
\hline Appendix B Intervista a Laura Pugno & 275
\end{tabular}

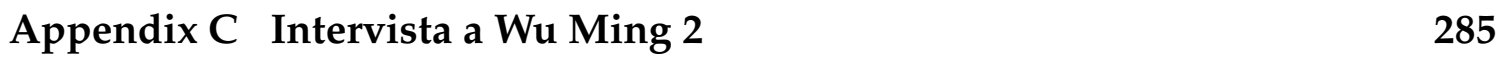




\section{Chapter 1}

\section{Introduction}

The Anthropocene defines the period when human activities begin to dramatically affect planetary processes: changing the chemical composition of the atmosphere, increasing the acidity of the oceans, eroding the stratospheric ozone layer, dispersing radioactive isotopes and polymers whose life is measured in aeons and triggering a mass extinction event, wiping out uncountable species from the face of the Earth, forever. The accelerated transformation of Earth's biophysical conditions poses an existential danger to life as we know it, and threatens to plunge humanity into an era where survival, let alone any form of civilisation, becomes an untenable proposition for billions. However, a deafening silence prevents a meaningful discussion about this topic on most public platforms: mass media, academia, politics. This has been true for a long time: the conservationist Aldo Leopold remarked that,

One of the penalties of an ecological education is that one lives alone in a world of wounds. Much of the damage inflicted on land is quite invisible to laymen. An ecologist must either harden his shell and make believe that the consequences of science are none of his business, or he must be the doctor who sees the marks of death in a community that believes itself well and does not want to be told otherwise (165). 
On the one hand, I claim Leopold's world of wounds for myself. A basic understanding of ecology and anthropology makes me aware that our unprecedented evolutionary success is rapidly changing the biophysical conditions upon which life as we know it relies upon. No day passes when I am not exposed to a litany of woe from the natural world: the oceans turning into seashell-dissolving soups of micro-plastics; birds, turtles and fish agonising in the oily sludge that has covered their home waters; the mangled bodies of whales, rhinos and elephants; the burning of the rainforests; the deadened buzz of poisoned bees; and, worst of all, the ideologues' cynical doublespeak. However, unlike others, I have no shell of scientific countenance that I can harden. Far from being a curse, this sensitivity has been a blessing in disguise that prevents me from falling into a deluded positivist cynicism and highlights the marks of death in today's decadent celebration of humanity's power as well as the widespread denial of Earth's physical limits.

Given my training as a Humanist and as an educator, I have endeavoured to understand what might be my personal contribution towards an heightened awareness of the dramatic state in which humanity finds itself. The Physical and Social Sciences have found definite roles in investigating the implications of such epochal transformation, but the Humanities have been slow in characterising their raison d'être in the Anthropocene. An ill-judged belief that the Humanities can ignore the non-human realm prevents some humanists from accepting that a modern understanding of ecology has turned the modernist world-view upside down, highlighting the arbitrariness of the assumptions that construct our identities. It is partly understandable: our vanity hurts when we hear that we are not as important, as unique, or as ethereal as we thought. But, more than vanity, mere inertia determines the current state of affairs: it takes a lot of effort to uproot outdated thinking.

This thesis is a humble but determined effort to understand whether the Humanities are as ineffective as some humanists believe. In it, I ask a simple question: is the role of literary writing limited to that of a cynical observer of the unfolding ecological catastrophe or can it play an active part in human survival? 
Environmentally-minded activists, scientists and intellectuals who seek to understand the global environmental crisis from different points of view are experimenting with new and more effective ways to inform the public about the dangers of a business-as-usual environmental policy. However, their message has to adapt quickly both to new scientific findings and to the attacks of those who find it convenient to minimise or deny these obvious urgencies. The aim of this work is to explore twenty-first century Italian literary responses to the ecological crisis, focusing on works that depict radically degraded environments. In doing so, it endeavours to understand how relevant these works are to the aims and challenges of environmentalism. Moreover, this research investigates what might be the social function of such literature. How do authors use language in order to communicate environmental degradation to the Italian public and how do they attempt to engender a heightened environmental awareness in their readership? How do they stimulate debate and, potentially, encourage direct citizen action against the abuses, while avoiding on the one hand the pitfalls of an exceedingly detached scientism, and on the other hand the misrepresentations of ideology? Finally, my research tries to determine whether twenty-first century Italian environmental literature might play a role in revising of the cultural frames that have contributed to global environmental change.

\subsection{A Scientific Foundation for Environmentalism}

Science warns that humanity is depleting the resources it depends on faster than they can replenish themselves. Rockström et al.'s important study attempts to define physical boundaries that should be observed to preserve a "safe operating space for humanity" (472). Rockström et al. describe nine ecological boundaries: (1) climate change, (2) ozone depletion, (3) atmospheric aerosol load, (4) ocean acidity, (5) freshwater consumption, (6) chemical pollution, (7) change in land use, (8) biodiversity loss, (9) nitrogen and phosphorus flow. In figure 1.1. the green area represents what Rockström's team proposed as the 
safe operating boundary for nine planetary systems. The red wedges represent an estimate of the position of the variables in 2009 (472). The graph captures

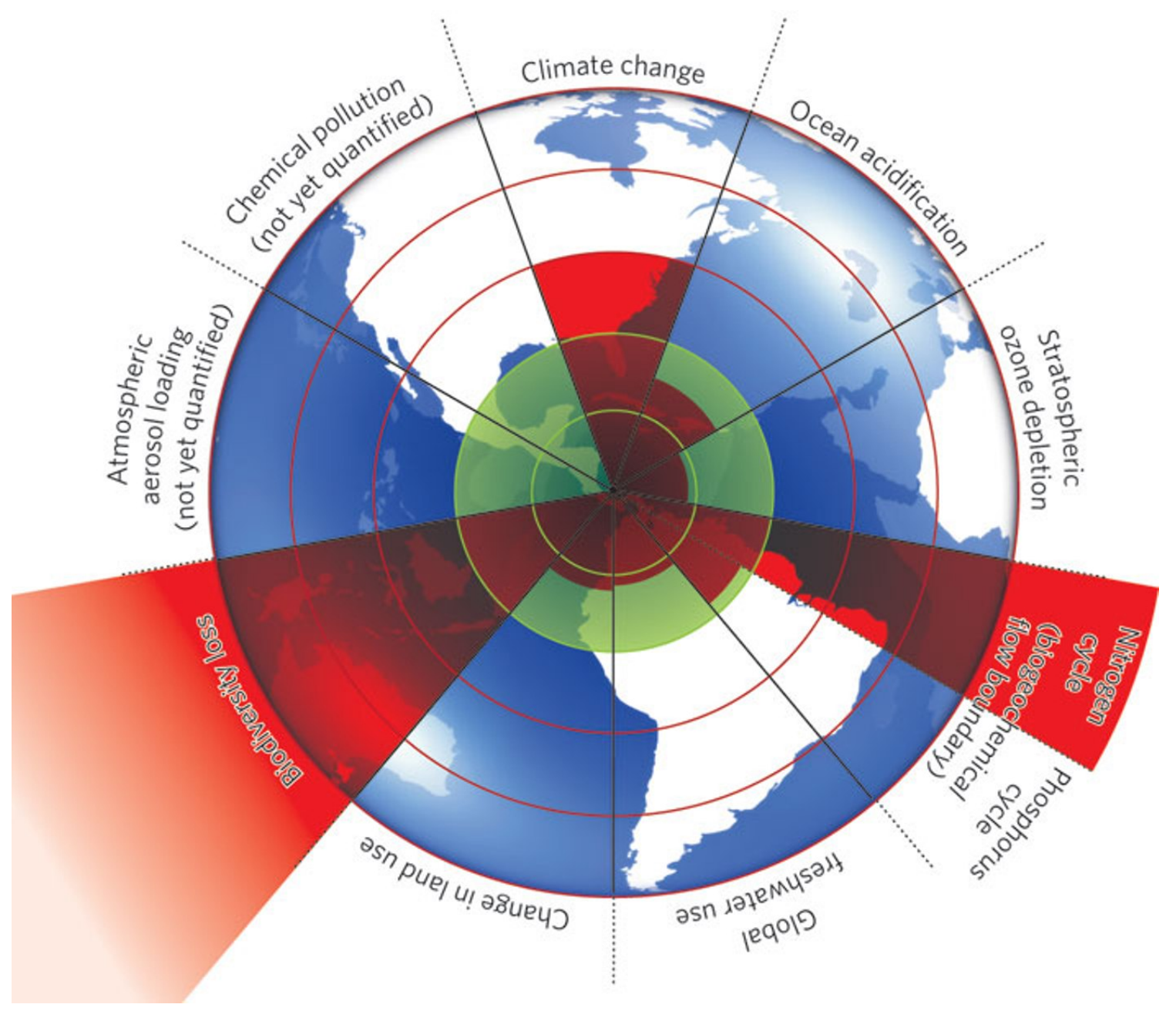

Figure 1.1: Rockström et al., Beyond the boundary in "A safe operating space for humanity" (Nature, 2009) 472. Reprinted by permission from Macmillan Publishers Ltd: Nature (3642431363537), copyright (2009).

more immediately than scientific prose the dramatic criticalities humans and other species are facing at the moment. Within it, a few trends are particularly important and urgent. The biodiversity loss wedge extends far outside the scale. Biodiversity is being depleted at alarming rates: it is calculated that 
species are becoming extinct 1,000 to 10,000 times faster than the background rate, an astonishing 140,000 species per year. They are being lost mostly due to habitat destruction in what has been labelled the Holocene extinction event (Pimm and Raven 843; Raven 46-51). A second criticality is the disruption of the nitrogen and phosphorus cycles. Runoff from agricultural fertilizers causes significant perturbation to global water cycles, causing eutrophication and global acidification, therefore pushing towards extinction plants that have evolved for efficient nitrogen use (Rockström et al. 474; Gruber and Galloway 293; Vitousek et al.738). The third criticality is global warming. It is projected that carbon emissions from fossil fuels could raise the global average temperature by $2.4^{\circ} \mathrm{C}$ to $6.4^{\circ} \mathrm{C}$ this century in a fossil fuel intensive scenario, severely jeopardising the viability of contemporary human societies (Rockström et al. 473; Solomon 749; Intergovernmental Panel on Climate Change, "Projected climate change and its impacts"'). It is to be noted that, whereas some boundaries have not been crossed yet, Earth systems are tightly coupled, and any imbalances can exacerbate other problems: for example, changes in land use might inject greenhouse gases (GHGs) into the atmosphere. These GHGs cause global warming as well as modify the ocean chemistry resulting in more acidic waters, which push vulnerable aquatic species towards extinction, and so on in a dangerous domino effect (Rockström et al. 474). In addition to these known environmental threats, there exist so-called "known unknowns". The first of these "known unknowns" is the fact that some boundaries have not yet been quantified due to inherent difficulties in collecting and evaluating the relevant data (Kriegler et al.). Also, there is uncertainty regarding positive feedback mechanisms embedded in the Earth system which might lead to self-reinforcing trends such as runaway global warming. For example, increased temperature in the Arctic melts the ice, allowing the darker water to absorb more heat, which in turn melts more ice. This stochastic element in Earth systems is often referred to as contributing to tipping points: physical observations show that ecosystems respond linearly only up to a certain level of disturbance. When this threshold is passed, a tipping point is reached, and the state of such ecosystems changes suddenly 
and dramatically to another one, from which it is very difficult to return to the previous state (Hansen et al., "'Target atmospheric CO2"). To summarise, whereas uncertainty is inherent to the scientific method, science suggests with "high agreement and much evidence" that, should current trends continue, "irreversible and, in some cases, abrupt environmental change, leading to a state less conducive to human development might occur" (Intergovernmental Panel on Climate Change, "Projected climate change and its impacts"; Rockström et al. 472). Rockström et al. highlight the fact that "human actions have become the main driver of global environmental change", either through overconsumption of limited resources, or through the release of harmful chemicals into the water, atmosphere, or land (472). Thus, it is beyond all reasonable doubt that a grave ecological crisis is underway, that its cause is human activity, and that present and future human welfare depend on the urgent modification of damaging trends. Considering the urgency and the large scale of this crisis, a change in awareness and in the modes of production is happening too slowly to prevent serious consequences, to the dismay and disbelief of environmentalists and scientists.

\subsection{The Response So Far: Swimming Against the Tide}

In 1946, Albert Einstein wrote in the New York Times Magazine that "[a] new type of thinking is essential if mankind is to survive and move toward higher levels" (Rowe and Schulmann 383). Although Einstein was writing about the threat of a nuclear holocaust, the quotation deals with human adaptation to new circumstances and can thus be applied to today's ecological crisis.

Kenneth E. Boulding has been quoted saying that "[a]nyone who believes exponential growth can go on forever in a finite world is either a madman or an economist" (Attr. to Boulding in Legislation and Military Operations Subcommittee and Committee on Government Operations). Likewise, in his 
Requiem for a Species, Clive Hamilton attributes the current ecological crisis to "the growth fetishism". To fetishise means to attribute "magical or supernatural powers" to something and similarly mainstream contemporary economics seems to assume that growth and the accumulation of wealth are the solution to any problem, a patently flawed conclusion (Hamilton, Requiem for a Species 32-33).

Technological advancements are part of the picture: solar power is reaching grid parity in some parts of the world, and wind is becoming a major player in the energy market (Beetz; Roney; BusinessGreen). Authoritative sources such as David J.C. MacKay and Howard Geller confirm the feasibility of a transition to a zero-carbon economy with current technology. The "Stern Review" (2006) concludes that the costs of inaction outweigh the costs associated with transitioning to a low carbon economy by up to a factor of 20 ("The economics of climate change: the Stern review"'). However, Ackerman et al. find that the Stern Review is likely to have underestimated costs and risks, and even Lord Nicholas Stern has recently admitted that climate-related damages could be higher than he estimated (Ackerman et al.; Stewart and Elliott). Renewable technology alone is insufficient. York finds that renewables have so far failed to displace carbon intensive energy sources: renewables could only do so "if they were deployed in a context where there were explicit policies aimed at reducing carbon emissions" (443). In democracies, this is only achievable through forward-looking politicians and people who understand the risk intrinsic in the continuation of the current flawed socioeconomical paradigm which is based on economic growth and on ignoring externalities.

New economic models that pursue other priorities than gross domestic product growth are being developed, such as the concept of "degrowth" and Kate Raworth's "Doughnut Economics", which aims at defining a path for human development within the unavoidable boundaries set by our constrained environment (Schneider, Kallis, and Martinez-Alier 511-8; Fournier 52845; Raworth). Unfortunately, such positive signals often go unreported in mainstream media or are drowned by the noise of the advocates of unrestrained economic growth. The fossil fuel industry is particularly active in funding 
public relation campaigns whose aim is obstructing action and ensuring that legislation fails to limit negative externalities (Oreskes and Conway). The result of this successful campaign of obfuscation is that, notwithstanding the destruction threatening humanity, mainstream media have consistently ignored or misrepresented environmental concerns worldwide.

Clive Hamilton suggests that this apparently absurd situation can be only understood when we realise that ecology and climate science have "thrown up some facts that challenge the foundation of the modern understanding of the world, that is, the conception of humans as self-determining agents able to control the future by exercising power over nature" (Hamilton, Earthmasters 206). A radical review of the way humanity relates to the non-human is in order, but overcoming the public's apathy is essential to motivate the radical changes that humanity owes to the next generations (Aitken, Chapman, and McClure). It is necessary to move away from what McCright and Dunlap define as "Dominant Social Paradigm" to an ecocentric approach where Nature is considered intrinsically valuable and invent a "grand narrative" of repairing the Earth (McCright and Dunlap 107; Washington, Climate Change Denial 119-120). But how?

\section{The Deficit Model}

Merely exposing the public to more information is an ineffective strategy. In the deficit model of scientific dissemination "scientists assume that there is a knowledge 'deficit' that can be 'fixed' by giving the public more information" effectively constructing individuals as blank slates who, on the one hand, possess erroneous beliefs attributed to the ignorance of scientific "truth", and on the other hand, can have a supposedly evidence-based opinion imposed on them by mere exposure to correct information (S. Brown 609). There is a wealth of research that discredits the top-down deficit model where scientists "filled the knowledge vacuum in the scientifically illiterate general public as they saw fit" (Miller 116). Kellstedt et al. conducted one of these studies, showing that "more information a person has about global warming, the less responsible he 
or she feels for it; and indirectly, the more information a person has about global warming, the less concerned he or she is for it" (Kellstedt, Zahran, and Vedlitz 122). In an interview with TIME magazine about her novel Flight Behavior (2012), novelist Barbara Kingsolver explains why she chose to write a novel about global warming including no specific villains: "throwing more facts at people clearly isn't working and there is an element of condescension in assuming that people who don't agree with you need more facts that you have" (Walsh). Thus, while it is important for the public to obtain access to information about the risks and the challenges of the Anthropocene, I argue that cultural studies and the humanities have a definite role to play in this scenario dominated by powerlessness and denial. A democratic transition must be founded on the development of a critical awareness and a sensitivity to non-human nature. In turn, those can act as antidotes to detachment, helping the public to realise the urgency of the matter. Whereas critical awareness is impossible unless scientific literacy spreads and the underlying reasons and consequences of global environmental change are understood, simple scientific information is insufficient to raise concern.

\section{Going Beyond}

To achieve real change, it will ultimately be necessary to resort to methods of communication that transcend rational and empirical thought. These methods must enable the public to intuit the fundamental links that interconnect humanity with the Earth's ecosystems and elicit a deep emotive response to the abuse and the destruction that are currently taking place (Hamilton, Requiem for a Species 153). In order to elicit such a response, the Humanities need to break free of some dangerous misconceptions have tainted it and adopt an ethical, reality-based approach. It has been apparent for too long that both modernist and postmodernist cultural studies have supported frontier ethics. On the one hand the grand narrative of modernism constructs itself around the ideologies of capitalism, socialism, resourcism, consumerism, and fails to see any value in nature beyond that of being a repository of resources for human 
consumption (Washington, Climate Change Denial 112). On the other hand, postmodernism assists the status quo in several ways. At its worst, postmodernist relativism has been, akin to Holocaust denial, "simply a fanatical rejection of evidence and a refusal to abide by the rule of rationality and logic" (Cohen 282). In addition, whereas it is true that postmodernism deconstructs the grand narratives of modernism, thus exposing its mistakes, it is also true that the same mechanisms prevent the arising of a "grand dream" of actually fixing things (Washington, Climate Change Denial 113). Finally, although postmodernism questions the centrality of dominant narratives and advocates the emergence of peripheral points of view, it has stopped short of critiquing anthropocentrism. As Washington observes, for a number of reasons postmodernism is critical of the idea of wilderness, as it could not fathom that anything existed beyond human experience ("The wilderness knot" 441).

So far, there have been calls for the humanities to project themselves over and above the limits of self-imposed frames and recognise the limits of (post)modernism. In his essay "Why Has Critique Run out of Steam? From Matters of Fact to Matters of Concern", Bruno Latour proposes a rethinking of the concept of critique by deconstructing its practice. Latour questions the necessity of applying deconstructionism to the empirical sciences for at least two reasons. The first reason is that it never worked: "[y]ou can try the projective game on UFOs or exotic divinities, but don't try it on neurotransmitters, on gravitation, on Monte Carlo calculations" (242). The second reason is that it would be unwise to try and attack science at a time when "extremists are using the very same argument of social construction to destroy hard-won evidence that could save our lives" (227). Instead of the old iconoclasm aimed at subtracting from reality, he proposes a type of positive inquiry aimed at "generating more ideas than we have received, inheriting from a prestigious critical tradition but not letting it die away, or 'dropping into quiescence' like a piano no longer struck": a switch from matter-of-fact to matter-of-concern (248). Similarly, Wu Ming argues that postmodernity is obsolete and that literature should dare to go beyond it, find new models and original frameworks to describe a profoundly 
mutated scenario: 1

Finita la postmodernità, il postmodernismo è patetico residuo, riscalda avanzi già avariati. La contemplazione allucinata della società dei consumi e del linguaggio che la descriveva ha espresso tutto quanto poteva esprimere (difficile, o meglio implausibile, andare oltre J. G. Ballard), e una volta individuate cose divertenti che non farai mai più, non le fai più, punto. Il tempo che viviamo ora non ha ancora un'etichetta, e ciò è bene. Abbiamo un margine di libertà [With the end of postmodernity, the postmodern is a pathetic residue, heating up already rotten leftovers. The visionary contemplation of consumeristic society and of the language which described it has already expressed all it could express (it is difficult, or rather, implausible to go past J. G. Ballard). Once you have identified enjoyable things that you will never do again, you do not do them again, full stop. The time we now live in does not have a label yet, and this is good. We have a margin of freedom] ("Premessa alla versione 2.0 di New Italian Epic" 32).

This freedom offers a chance to revise our cultural frames and allow us to opt out of subservient modernism and nihilistic postmodernism. Thus, not rejecting but transcending the canons of postmodernity, this thesis aims to investigate how literature can find a new framework of operation and become a powerful cultural force helping humanity towards survival. In this scenario, the role of the Humanities would be that of investigating and generating epiphanies that transcend empirical thought, overcoming "growth fetishism", and thus eliciting a deep emotive response to the abuse and destruction that are currently taking place.

\footnotetext{
${ }^{1} \mathrm{Wu}$ Ming define themselves as a "band" of authors, founded in January 2000. Their début work was the the best-seller novel $Q$, which they published under the pseudonym Luther Blissett. Subsequent collective works of Wu Ming include 54 (2002), Manituana (2007), and Previsioni del tempo (2008).
} 


\subsection{A Brief History of Italian Environmental Activism}

Following the evolution of organised environmental activism in Italy (table 1.1) by mapping the history of preservationist associations is a straightforward way to trace the development of environmental awareness among Italians. The origins of environmentalism in Italy can be traced back to the second half of the nineteenth century, as the intellectual and scientific elites became aware of the need to protect places of outstanding natural beauty from human exploitation, leading to the foundation of associations such as the "Touring Club Italiano" and the "Lega Nazionale per la protezione dei monumenti naturali" (De Luca). The First World War and the subsequent rise of fascism led to a long hiatus in the development of environmentalism in the country, a discontinuity determined in part by fascism's efforts to enforce economic autarchy and industrialism, and in part by the elitism of the environmental associations that failed to connect with a generally poor and illiterate population (Van Koppen and Markham 119-20; Della Seta 74-75). This hiatus was only overcome in the mid-1950s, when new associations such as "Italia Nostra" were created which criticised the damage that post-war industrialisation and urbanisation had wrought (Della Seta 13). However, these associations repeated the mistakes of their predecessors because they were still fundamentally elitist in nature, and based their policies on the desire to preserve the aesthetic value of select landscapes rather than on the pragmatic need to protect functional ecosystems (De Luca; Della Seta 15; Van Koppen and Markham 120). Thus, the first attempts at creating an environmental awareness in Italy produced limited outcomes for several reasons. Firstly, because of their scarce relevance within Italian society; secondly, because they considered nature as an aesthetic value rather than a valuable asset; thirdly, because their elitism failed to grant them popular support; and finally, because the rise of fascism suppressed popular movements and highlighted the lack of civic cohesion in Italy.

Only with the great social turmoil of the 1960s did environmental movements 


\begin{tabular}{l||l|l|l} 
Name of the organisation & $\begin{array}{l}\text { Year } \\
\text { Founded }\end{array}$ & $\begin{array}{l}\text { Annual Budget } \\
\text { (thousand } € \text { ) }\end{array}$ & $\begin{array}{l}\text { No. of } \\
\text { members }\end{array}$ \\
\hline Club Alpino Italiano (CAI) & 1863 & & \\
Touring Club Italiano (TCI) & 1894 & & \\
Italia Nostra & 1955 & 4,600 & 12,000 \\
Lega Italiana Protezione Uccelli & 1965 & 3,800 & 40,000 \\
WWF Italia & 1966 & 16,000 & 200,000 \\
Legambiente & 1980 & 5,500 & 110,000 \\
Greenpeace Italia & 1986 & & \\
\hline
\end{tabular}

Table 1.1: Main Italian environmental associations: chronology, budget and members. Source: Van Koppen, Kris, and William T. Markham. Protecting Nature: Organizations and Networks in Europe and the USA (Cheltenham: Edward Elgar Publishing, 2008): 119, 127.

start to gain popularity in Italy. Several factors contributed to increased awareness of environmental matters among the Italian population. The first factor was, quite simply, that no one could ignore pollution anymore. In the 1960s, it became evident on a global scale that rapid industrialisation had some serious drawbacks in terms of degradation of natural environments, with consequences which disproportionally affected the working class (De Luca; Della Seta 18-19). Italian environmental disasters like the one in Seveso in 1976, and international accidents like those of Three Mile Island (1979), Bhopal (1984) and Chernobyl (1986) focused public attention on the effects of chemical pollution and radiation, highlighting criminal disregard for human life. In Italy, Marxists were swift to read environmental problems as another proof of the crimes of capitalism, but calls to protect the natural heritage were bipartisan and were widely reported in the media across the political spectrum (De Luca: Della Seta 20-21; Van Koppen and Markham 124).

The second factor that contributed to the rise of environmental awareness in Italy was widespread public education, which made it possible to popularise scientific findings for a non-specialist audience. In the 1960s, the "subversive" science of ecology gained prominence within academia (Sears). Scientists 
grasped the severity of the damage that industrial processes inflicted on ecosystems and its consequences for humanity. Concerned and forward-looking scholars began efforts to outreach and campaign to minimise the damage, developing insight towards the discipline of environmental communication. While environmental science was previously confined to specialist jargon-filled journals, popular science works introduced an alternative to the predominant discourse of industrialism and anthropocentrism. Thanks to these pioneer communicators, an increasing fraction of the public became aware of ecosystems degradation and of the fact that repercussions of ecological destruction went beyond the mere loss of beautiful sights. The book that opened a new era in environmentalism throughout the world and propelled it into the mainstream was Rachel Carson's Silent Spring (1962). Silent Spring detailed the insidious effects of uncontrolled use of biocides, questioning for the first time in modern history the faith in a model which sees humanity in a merciless struggle against a nature "red in tooth and claw". In her book, Carson explained that the cause of the mysterious illnesses that afflicted land, humans and non-humans alike was the casual use of the new synthetic biocides, a link that was confirmed when President John F. Kennedy's Science Advisory Committee investigated her claims (Lear 38; H. S. Bennett et al.). Carson took a brave stance against the powerful chemical corporations which advocated a scorched earth policy, battling cancer as well as powerful vested interests. She replaced an as-yetunchallenged faith in chemical salvation against an encroaching malevolent nature with an alternative vision of ecosystems as tightly coupled systems which go haywire when mindlessly tampered with, and of humans as inextricably connected to their environment and ultimately bound to reap the consequences of any environmental abuse. Silent Spring became available in Italy in its 1963 translation Primavera Silenziosa, which had a remarkable success among the public, helping to push into the limelight environmental topics that the media had previously ignored, such as overbuilding and pollution (Della Seta 20). Following the success of Primavera Silenziosa, scientists such as Laura Conti, Antonio Cederna, and Fulco Pratesi among others could suddenly 
count on an increased interest and a readership sensitive to the theme of environmental degradation. Environmental groups also benefited from the increased attention, but many soon learned that the old formula based on the protection of beautiful sights lacked effectiveness. Instead, new environmental groups were created which mixed political action with appeals to emotive environmental sensitivities: the Italian section of the World Wildlife Fund (WWF) and the Lega Italiana Protezione Uccelli (LIPU) took a more systemic approach to the protection of ecosystems (Van Koppen and Markham 124; Della Seta 22-23). Among this second wave of environmental activism, Legambiente (founded in 1980) deserves special mention, having distinguished itself because of its scientific approach to environmental protection which encourages citizen participation (Legambiente, "Perché un ambientalismo scientifico"; Della Seta 89). Legambiente also focuses on combating ecomafia and publishes the yearly Ecomafia report in cooperation with Italian law-enforcement agencies, which details the results of the investigations of, and crime suppression of, environmental crimes (Legambiente, "“Perché un ambientalismo scientifico"). A subsequent entry in the landscape of environmental activism was the Italian branch of Greenpeace in 1986, which promotes a more aggressive brand of environmentalism based on direct action.

While elite environmentalism based on aesthetics had failed to engage politics, modern conservationist associations were born because the issue of environmental degradation could not be ignored any longer when the media started to report on high profile environmental accidents. New environmental groups based on an increased interaction with the public emerged, their power based on the popularisation of environmentalism and their policies focused on visible, prominent issues. The support for environmental issues climaxed in the 1976 environmental campaign in the aftermath of the Seveso accident, and in victory of the anti-nuclear stance on the abrogative referendum on nuclear power in 1987 (Della Seta 39-54; Van Koppen and Markham 125; De Luca).

Notwithstanding this victory, Italian environmentalism has so far failed to gather significant political momentum, never able to summon the numbers of 
its German or British counterparts. Italian environmental movements have a noticeably weaker structure and fundraising capacity in comparison to other European countries, and can count on fewer members, fewer professional skills, and less political influence (Van Koppen and Markham 128). Indeed, political influence has always eluded the Italian greens. Their 1987 victory in the referendum against nuclear power was a short-lived one, which failed to trigger a mass movement: in the 1987 political elections, the Liste Verdi obtained fewer than 1.6 million votes between the Senate of the Republic and the Chamber of Deputies (Ministero dell'Interno). 2 The influence of the Green Party climaxed with about 2.2 million votes at the 2006 political elections ( 26 seats total), only to decline until it eventually disappeared from the Parliament as an independent party in 2008 (Ministero dell'Interno) ${ }^{3}$ The evolution outlined here shows that the environmental movement has failed to achieve as much political traction in Italy as in other countries. The reasons for such failure are multiple and go beyond the scope of this research, but may be traced to poor leadership and lack of political ambition as well as to the fragmentation of the Liste Verdi between incompatible visions of what being "green" means. Moreover, the financial crisis of 2008 might have convinced Italian voters to leave green issues in the background and to focus instead on what were perceived as more urgent economic concerns.

The post-war economic boom brought awareness of the problems of unchecked industrialisation to public attention. Many believe that Silent Spring was the spark that initiated a mass movement which attempted to disrupt the most destructive excesses of industrialism and capitalism. Nonetheless, a spark without fuel is incapable of lighting a fire, and many factors contributed to spreading the environmental movement in Italy in the early 1960s. A flowering and diversification of environmental associations

\footnotetext{
${ }^{2}$ Chamber of Deputies: 969.218 votes, 2.51 percent, 13 seats; Senate: 634.182 votes, 1.96 percent, 1 seat.

${ }^{3}$ Chamber of Deputies, Federazione dei Verdi (excluding voters abroad and the Aosta Valley): 784.803 votes, 2.06 percent, 15 seats; Senate, Insieme con l'unione (excluding voters abroad, Aosta Valley and Trentino Alto Adige): 1.423.003, 4.17 percent, 11 seats.
} 
ensued, seeking to cater to the many sensibilities of the pool of potential supporters. However, an environmentalist consciousness never quite took hold socially and politically in Italy, and the Greens remain a fringe political force with little to no parliamentary representation.

\subsection{Environmental Literature in Italy}

Although my research focuses on twenty-first century Italian environmental literary writing, in this section I will briefly sketch the evolution of environment and nature writing in Italy since its inception. Academia has until recently mostly neglected to study the theme of nature in Italian literary writing, notable exceptions being the work of Dr. Serenella Iovino of the Università degli Studi di Torino, and Barron and Re's anthology Italian Environmental Literature. However, nature has undeniably been of great importance in Italian literary writing, so much so that Italian literature began with an act of mystic celebration of nature: perhaps the first literary document in the Italian language is Saint Francis of Assisi's "Cantico delle Creature", a religious poem composed in 1224 in the Umbrian vernacular that celebrates the beauty and grace of nature as God's creation. In the canticle, Saint Francis personifies natural elements and celestial bodies, and even death, describing them as humanity's brothers and sisters before God: Wind provides creatures with sustenance, Water is useful and precious, Fire lightens the night, Earth produces fruits, grass, and colourful flowers. In the Compilatio assisiensis, his followers report further on his thought towards non-human life: “Ogni giorno usiamo delle creature e senza di loro non possiamo vivere, e in esse il genere umano molto offende il Creatore. $\mathrm{E}$ ogni giorno ci mostriamo ingrati per questo grande beneficio, e non ne diamo lode, come dovremmo, al nostro Creatore e datore di ogni bene" [We use the creatures every day, and we cannot live without them, and in them humankind gravely offends the Maker. Every day we fail to be grateful for this benefit, and we fail to praise the Maker, the source of all goodness] (Bigaroni). In his poetry as well as in his prose, Saint Francis sees nature as a precious resource on 
which life depends. It is true that in Saint Francis' theocentric thought praise for creation stems from faith, and nature is the means through which God bestows gifts to humanity. However, his message reveals a sense of awe, responsibility, and gratitude towards nature that is uncommon nowadays. What is left of his attitude then, and how has twentieth and twenty-first century literature responded to the unprecedented destruction that a century of industrialism and frontier ethics have wrought upon Earth?

\section{Narrating Ecology in the Twentieth Century}

Barron and Re's anthology Italian Environmental Literature (2003) provides an inclusive overview of Italian literature of the late-nineteenth to late-twentieth century, from Giovanni Pascoli's poetry to Gianni Celati's prose to Fulco Pratesi's environmental writing. In the second half of the twentieth century, a shift in the perception of nature appears in Italian writers: at that time, observers within both the humanities and science start to acknowledge the rapid decay of natural environments. Until then, nature had been perceived as an infinitely renewable, awe-inspiring reality to be reckoned with, a force that could dwarf any human enterprise. After the mid-twentieth century, however, all this changed: nature became a "vulnerable organism already scarred by humanity" (Barron and Re 258). Two types of authors defined this new vision of a wounded nature. The first type consisted of scientists. In 1982, medical doctor Laura Conti published Una lepre con la faccia di bambina [A hare with a child's face] in the aftermath of the Seveso disaster using the narrative form to convey the biological as well as the social consequences of exposure to dioxin. Archaeologist Antonio Cederna dedicated much of his writing career to denouncing the disfigurement of Italy's natural and cultural heritage. In 1972, Emeritus professor and senator Giorgio Nebbia questioned the wholesomeness of the relationship between humanity and the environment as well as the faith in boundless human development, envisioning a society based on Franciscan solidarity among all living beings in his Il punto di vista cristiano sull'ecologia [A Christian point of view on ecology]. 
Along with scientists, humanists of the second half of the twentieth century became sensitive to the fact that the decay of ecological systems foreboded the decay of civilisation. Among the foremost literary writers, Italo Calvino and Pier Paolo Pasolini are perhaps those who first sounded the alarm on the dangers of waste and pollution, closely followed by Loriano Macchiavelli.

Calvino seems to be uninterested in writing about the environment during the 1950s. Even in La speculazione edilizia [A plunge into real estate] (1963), Calvino's preoccupation is with the loss of a moral compass more than with environmental decay caused by overbuilding during the economic boom. However, the author's sensibility to distress signals from the rapidly changing natural world of Italy's economic boom emerge in Marcovaldo, ovvero Le stagioni in città [Marcovaldo or the Seasons in the City] (1963). In it, the main character Marcovaldo embodies love for an urban nature that is changing so fast as to be barely recognisable. This naïve attitude causes him and his family a lot of trouble: from trying to spend the night camping on a bench in "La villeggiatura in città" [Park-bench vacation] to fishing in a contaminated river in "Dov'è più azzurro il fiume" [Where the river is more blue?]. Two years later, in La nuvola di smog $[\mathrm{Smog}]$ (1965), Calvino uses pollution as a metaphor for existential malaise. Calvino's social critique sharpens in Le città invisibili [Invisible cities] (1972), a collection which includes an examination of consumerism in the story "Le città continue. I" [Continuous cities. I]. Leonia is a city obsessed with novelty where new products are produced and discarded just as fast as rubbish accumulates in ever-growing mountains of waste that encroach on the city and threaten to submerge it. Not only is Leonia's mountain of waste ever-growing, but it also becomes increasingly resistant to decay: "più l'arte di Leonia eccelle nel fabbricare nuovi materiali, più la spazzatura migliora la sua sostanza, resiste al tempo, alle intemperie, a fermentazioni e combustioni. È una fortezza di rimasugli indistruttibili che circonda Leonia" [the more Leonia's talent for making new materials excels, the more the rubbish improves in quality, resists time, the elements, fermentations, combustions. A fortress of indestructible 
leftovers surrounds Leonia] $]^{4}$ Calvino prophesizes that Leonia's ever-increasing garbage tip will keep growing until an apocalyptic landslide "sommergerà la città nel proprio passato che invano tentava di respingere, mescolato con quello delle città limitrofe, finalmente monde: un cataclisma spianerà la sordida catena montuosa, cancellerà ogni traccia della metropoli sempre vestita a nuovo" [submerging the city in its own past, which it had tried in vain to reject, mingling with the past of the neighboring cities, finally clean. A cataclysm will flatten the sordid mountain range, canceling every trace of the metropolis always dressed in new clothes] (Le città invisibili 120). Even garbage tips have tipping points!

Pier Paolo Pasolini, too, was an attentive observer of his time, and was as concerned with people and urban life as with rural ecosystems, believing that the two were profoundly interdependent realities. As a film-maker and a journalist, he denounced the destruction of Italy's cultural and natural heritage, especially lashing out against uncontrolled industrialism and the degradation of the countryside due to ecological, urban, and landscape mismanagement (Chiesi). His poetry as well as his prose describes a rapidly mutating Italy, where greed and thirst for power have upset traditional balances and enveloped Italian society with a sticky, poisonous film of moral decay which permeates the urban environment. In the cryptic novel Petrolio [Petrolio], which was incomplete at the time of his death in 1975, Pasolini contrasts his memories of a pre-industrial Rome dirty with just "cartaccia e merda" [wastepaper and shit] with the vision of a post-apocalyptic "terra degradata, inquinata - acqua, animali, erbe, cimiteri di residui $\langle$ ? $\rangle$ e plutoni - monumenti funebri centrali termo-nucleari (oltre che rovine contorte di tutto ciò che riguarda il petrolio, dalle raffinerie ai benzinai)" [disfigured, polluted earth - water, animals, vegetation, cemeteries of wastes $\langle ?\rangle$ and plutonium dumps - thermonuclear power plant funeral monuments (in addition to the twisted ruins of everything having to do with oil, from refineries to gas station attendants)] (Pasolini, Romanzi e racconti: 1946-1961 20, 464).5 $\mathrm{He}$ prophesies that a "third end of the world" would begin within 30 years from

4 All translations of Le città invisibili by William Weaver from Calvino, Invisible Cities.

${ }^{5}$ Translation by Ann Goldstein from Pasolini, Petrolio. 
the time of his writing due to the finiteness of nature, following a "first end of the world" due to the dangerousness of nature, and a "second end of the world" due to the dangerousness of man (411). The "finiteness of nature" is perhaps an idea that Pasolini borrows from the hugely successful Club of Rome's Limits to Growth report published in 1974, whose business-as-usual scenarios theorise the collapse of the world system within the twenty-first century as human activity depletes all of the natural resources it depends on. In 2004, the Club of Rome published a "30-Year Update" to its 1974 report and their work has produced an extensive legacy of scientific research such as Rockström's paper on planetary boundaries and the concept of Ecological Overshoot Day, which each year symbolically signals the day when humanity starts consuming more than the Earth's ecosystems can provide: in 2012, it fell on August 22nd (Global Footprint Network). As humanity expands ever more its influence over the natural world, Pasolini's words on the "finiteness of nature" ring ominously true.

Italy has proven to be a fertile territory for the noir environmental crime novel and Italian twenty-first century narrative has easily been able to integrate the theme of environmental crime, which is but another facet of the complex relationship between the biosphere and human society. A pioneer of the literary environmental movement and a prominent writer of noir novels is Loriano Macchiavelli, who published Sequenze di memoria [Sequences of memory] first in 1976 and again in 2011 as part of the VerdeNero series. Sequenze di memoria was the first attempt at econoir by an Italian writer. In the preface to the 2011 edition, Macchiavelli writes that Sequenze di memoria "è il primo romanzo che si occupa del moribondo ambiente. E di chi lo sta uccidendo. Sarebbe bello scoprire l'assassino universale! Cosa volete che siano, al confronto, i nostri piccoli omicidi quotidiani?" [is the first novel about the dying environment, and about who is murdering it. It would be great to discover the universal murderer. How trivial are our little daily homicides in comparison!] (Macchiavelli vii). Loriano Macchiavelli's novel appears as a conventional noir featuring unresolved murders, conniving authorities, and an amateur investigator, but on a deeper level, it denounces the murder of nature during the economic boom 
by contrasting the main character's memories of a thriving countryside with the reality of a compromised environment. Important themes of the novel are the inability of the townspeople to recognise that the price they pay for their industrial jobs is the deterioration of their living environment and the complacency of the authorities who refuse to pursue environmental crimes because it would damage entrenched powers.

Notwithstanding the excellent names among the Italian literati that from the 1970s denounced the risks of unchecked material growth, environmental degradation remains an undercurrent theme from the 1980s to the early 2000s, with authors tending to focus on local or single issues or describing traditional rural life and still-beautiful corners of the country. In 1986, Gianni Mattioli and Massimo Scalia wrote about the Chernobyl accident in Il Manifesto [The manifest], criticising the use of nuclear energy in their article "Prometeo è caduto a Chernobyl" [Prometheus fell in Chernobyl] (Mattioli and Scalia). In Una storia ecologica [An ecological story] (1998), Loredana Lucarini describes how car manufacturer Alfa Romeo brought both jobs and pollution to Arese, and how the locals fought a ten-year-long battle to force the company to adopt less harmful practices. Barron and Re's anthology Italian Environmental Literature contains an unpublished manuscript by Giuseppe Moretti describing his attempt to build a farm that would restore the primeval habitat of the Pianura Padana, now reduced to an "ecological desert" by centuries of intensive farming (Barron and Re 321-26). However, many more authors prefer to leave political criticism aside and focus on describing Italy's heavily anthropised nature. Among those, the best-known is perhaps Gianni Celati, who narrated the urbanised Po Valley in the 1990s in his books Narratori delle pianure [Narrators of the plains] (1988), Verso la foce [Towards the river mouth] (1992) and Quattro novelle sulle apparenze [Four novels about appearances] (2002).

Pasolini's writing took universal and apocalyptic tones, Italian literature in the late twentieth century appears much tamer, and later writers seem intent in pursuing localised and pragmatic approaches to the relatively new concept of environmentalism. 


\section{A Rude Awakening: Twenty-First Century Italian Environmental Writing}

In the past 15 years, the scientific community and, to a lesser degree, the wider public have increased their grasp of the dramatic state of global ecosystems and the urgency of systemic changes in the way humanity obtains the resources for its development. However, the early twenty-first century has also been a time when industry mounted a well-organised and well-funded reaction to the spreading of environmental awareness, leading to a public relations battle that rages on almost all media. While twenty-first century environmental communication develops some of the earlier themes and modes, it also reflects as deep transformation, including the loss of a naïve faith in the powers of rational discourse. As the damage wrought to the environment becomes impossible to ignore and the urgency to act impossible to deny, a new strand of political literature emerges, one that denounces the grave ecological state of huge areas of the Italian peninsula and the criminal plans which lie behind much of this damage.

As Wu Ming note in their essay collection New Italian Epic, many authors also feel driven to a new type of "just and serious" literature, breaking away from what they perceive as the political disengagement of the previous years (Wu Ming, New Italian Epic 23). Perhaps the most notable work that Wu Ming include in the "New Italian Epic" (NIE) nebula was Roberto Saviano's hugely successful book Gomorra [Gomorrah] (2006), which brought the phenomenon of ecomafia to the attention of the Italian public. At almost the same time of Gomorra's publication, the publisher Edizioni Ambiente launched the "VerdeNero Narrativa" [VerdeNero Narrative] series in cooperation with Legambiente's Osservatorio Ambiente e Legalità [Observatory for the Law and the Environment]. VerdeNero is a collection containing 36 titles published between 2006 and 2010, and boasting works from well-known authors such as Wu Ming, Giancarlo de Cataldo and Carlo Lucarelli, among others, as well as lesser-known and first-time writers, who agreed to write about ecological crimes. VerdeNero authors adopt a hybrid style of narration which fuses fiction with non-fiction, letting the two narrative modes complement each other. Likewise, 
in this period, a few writers have engaged with the environmental genre outside of the VerdeNero label: Laura Pugno débuted with her science-fiction novel Sirene [Mermaids] (2007) and, a year later, Tommaso Pincio published Cinacittà [Chinacity] (2008). In 2010, the writing ensemble Kai Zen completed the ecothriller Delta Blues. Finally, in 2012, Antonio Scurati published La seconda mezzanotte [The second midnight]. These works enrich and diversify the Italian literary landscape, introducing environmental themes such as climate change, chemical pollution, and land use change into the public discourse.

As an introduction to the close-reading and in-depth analysis of the literary works presented in chapters 3, 4 and 5, I shall briefly list them here, highlighting the ecological themes behind their selection. Chapter 3 focuses on the representation of polluted environments. It opens with the analysis of Gomorra's last chapter, "La terra dei fuochi" [The land of fires], where Roberto Saviano gives a personal account of living (and dying) in the Land of Fires, an area north-east of Naples notorious for its illegal dumping sites. The second work I consider in this chapter is Delta blues, Kai Zen's contemporary rewriting of Joseph Conrad's Heart of Darkness, highlighting the plight of the populations forced to live in the Niger Delta areas degraded with oil pollution. The final section of chapter 3 is dedicated to Previsioni del tempo. In this novel, Wu Ming uncover the dynamics of ecomafia by narrating the journey of two menial ecocrime labourers from Naples to Emilia Romagna aboard a truck full of illegally slaughtered pork. In chapter 4, I consider the representation of land-use change and landscape degradation. The first work I analyse in this chapter is Rovina, a short novel that narrates how the business of illegal building degrades traditional landscape and the lives of those who become involved with it. The second section considers Fuoco!, a coming-of-age story about teenagers fighting Camorra arsonists. Finally, I return to Gomorra and highlight how Saviano exposes the mechanisms through which the Camorra profits from the degradation of the territory. In chapter 5, I focus on translocal ecological degradation. The first work I consider here is Sirene, where Laura Pugno describes the troubled relationship between a cruel humanity facing 
extinction and a newly discovered quasi-human species of mesmerising beauty. Finally, I analyse Alessandra Montrucchio's E poi la sete, a climate fiction novel about the friendship between a woman and a young man who live in a world devastated by global warming and chronic thirst. 


\section{Chapter 2}

\section{Methodology}

\subsection{Exploring the Field}

Humanists who focus on understanding human nature through its literary expressions must remember that, in spite of its supposed godlikeness, the human species is also subject to physical laws and that humanity's existence and prosperity depend on the health of the environment that surrounds it. It would be impossible to understand humanity in isolation from the substrate that defines and supports it. However, the rich interaction between literary writing and the environment has so far been generally disregarded in Italy, and even less attention has been paid to literary writing that depicts polluted or degraded environments despite nature having been the inspiration and focus of countless writers and poets since the beginning of the Italian literary tradition. This is surprising because, in addition to its literary tradition, Italy is both endowed with an extraordinary natural and cultural heritage, and beset by enormous environmental problems which can be traced to a short-sighted and predatory disconnection from the natural world.

My thesis addresses the gap in scholarship that exists around the depiction of degraded places in contemporary Italian literature. In it, I analyse a selection of works that describe human societies that live with the consequences of grave environmental degradation; I use the tools of literary analysis to show how 
these texts contribute to undermine harmful ideologies and create an increased awareness of humanity's role within the global biosphere and of the limits of its agency.

\subsection{Rationale for the Selection of Works}

Human-driven rapid changes in the biosphere characterise the Anthropocene. Global warming, the Sixth Extinction Event, environmental crime and urbanisation are dramatically upsetting the biosphere. Many of the alarms that scientists and intellectuals sounded in the 1960 are now woefully inadequate to represent global environmental change in the twenty-first century. However, fossil-fueled prosperity masks the worsening of the environmental situation to the wider population, so that the problem is largely being ignored. These considerations define the rationale adopted in a necessarily limited selection of literary works for deeper analysis. A number of criteria have been used to identify narratives of interest to the research questions:

1. Relevancy: selected texts are relevant to current critical environmental issues;

2. Recency: texts have been published in the twenty-first century so as to report more closely the rapidly changing nature of the environmental crisis;

3. Activism: the author's intention needs to be political (in the broadest sense), deliberately promoting awareness of real problems that afflict Italian society or humanity.

Whereas relevancy and recency are self-explanatory criteria, explicit activism is a very important characteristic of environmental literary writing: writing about the state of the world is intrinsically political because it counters the dominant discourse of frontier ethics. Likewise, an engaged approach to narrative production is the primary characteristic of NIE (see 1.4), a framework that colours the entirety of my literary analysis: 
Giusto e serio. I due aggettivi non sono scelti a caso. Le opere del New Italian Epic non mancano di humour, ma rigettano il tono distaccato e gelidamente ironico da pastiche postmodernista. In queste narrazioni c'è un calore, o comunque una presa di posizione e assunzione di responsabilità, che le traghetta oltre la playfulness obbligatoria del passato recente, oltre la strizzata d'occhio compulsiva, oltre la rivendicazione del «non prendersi sul serio» come unica linea di condotta [Just and serious. The two adjectives have not been picked by chance. New Italian Epic works do not lack humour but reject the detached and frigidly ironic tone of postmodern pastiche. In these narratives there is a warmth, or anyway a stance and an assumption of responsibilities that propels them beyond the obligatory playfulness of the near past, beyond the compulsive winking, beyond the demand of «never taking yourself seriously» as an only policy]

This statement has been the cause of much controversy within and outside Italy, and many critics argue that relativistic cynicism and ethical void do not characterise all of postmodernist production. This may be true, but it appears to me that Wu Ming's words have somehow been misrepresented: far from disparaging all of the postmodernist canon, by highlighting the ethical approach of NIE production, Wu Ming intended to set it apart from other works whose ethical dimension is secondary to aesthetic considerations. Although I am aware that there exists much engaged literature outside NIE, it appears to me that NIE is the most explicit and most concerted attempt to aggregate literary works that explicitly convey a message about the need to review the current social framework. Beyond all controversies, NIE's aspiration to a "just and serious" narrative highlights the ethical undertone that reverberates in all of the works that I will consider. 


\subsection{Literature Review}

But how can literary writing affect behaviour and create the conditions for a review of the growth- and greed-obsessed paradigm that currently drives great part of humanity? Indeed, literary writing is "soft power" at its softest because it has no power beyond the force of the ideas it expresses and perhaps the authoritativeness of its author. Yet, literary writing can convincingly and articulately express radical and innovative ideas. I believe it is worth at least considering the possibility that such texts can raise questions and introduce ideas that could allow receptive readers to gain insight into the flaws of humanity's current approach to progress. A few interpretive frameworks in particular can be used to explore the impact of environmental literary writing, thus creating in readers the conditions for a deep reflection about the role of humanity within the living world.

\subsubsection{Cognitive Literary Theory}

Most literary criticism explores texts for what they are: close reading unveils the literary mechanisms and the hidden layers of meaning that make up a text, enhancing the pleasure of reading. Close reading is a fundamental skill to deeply understand a text, but it only reveals what a text is. Equally interesting is trying to understand what a text does: if it is true that the current socio-economic growth-obsessed paradigm is corroding the living substrate that nurtures and supports humanity, what might be the role of literature, of the arts and of the Humanities in a democratic and non-violent revolution that would allow humanity to flourish in the twenty-first century and beyond?

Cognitive poetics or cognitive literary theory (CLT) is a recently developed critical approach which relies on cognitive science to determine how literary texts affect the reader, trying "to base its claims on relatively solid scientific fact while not failing to treat the text as literature" (T. E. Jackson 191). The assumption underlying CLT is that humans as a species produce and enjoy literature because, from an evolutionary point of view, it allows them to safely 
strengthen and refine their cognitive skills, learn to successfully decode partial and contradictory sensory inputs, and navigate ever more complex social webs through enhancing the theory of mind (ToM), that is, the ability to attribute mental states to themselves and to others. Thus, I employ CLT to provide a rigorous interpretive framework and to determine "why and how" specific texts may enhance awareness about environmental issues (Richardson and Steen 3). Most importantly, reading literary texts through the lens of CLT could "help advance a more detailed understanding of forces that both enable and constrain cultural change" $(6)$. When readers explore a work of fiction, they automatically attribute states of mind to and identify with characters inhabiting worlds which can represent-faithfully or symbolically — situations that others may be experiencing. Through these processes of projection and impersonation, they are encouraged to feel what the characters feel, and face (albeit safely) the same challenges characters face. This reading of literary texts aims not only at unveiling what the author communicates, but also at investigating how such works interact with readers, contribute towards an enhanced awareness of environmental problems and solutions, and ultimately encourage a modification of behavioural and cultural patterns which may contribute towards the creation of a sustainable and value-driven social paradigm.

Because it strives to unveil the modes and reasons that make fiction meaningful for readers, CLT is "highly compatible with well-thought-through literary criticism" (Zunshine 5). In her essay entitled "Cognitive Ecocriticism: Human Wayfinding, Sociality, and Literary Interpretation", Nancy Easterlin explains that

the prospect of a cognitive ecocriticism ... might seem to be an unwarranted conjunction of fields motivated by different principles and focused on quite distinct phenomena. But in fact, cognitive science and evolutionary psychology are relevant to all areas of literary studies. Because human minds stand behind all human activity, including literary activity, knowledge of the mind is relevant to any literary account of the environment (257). 
As our senses pick up physical stimuli, our minds weave mental representations of the physical world that surrounds us. However, these representations become affectively charged because "humans exhibit a range of instrumental biases, all of which enhance their ability to identify attractive resources, to avoid predators, to negotiate physical space, and to engage in sexual-procreative activities" (Easterlin 260). But affectively charged representations are not limited to what individuals experience in their lifespans, and associations developed from time immemorial still heavily influence human behaviour. For instance, ophidiophobia (fear of snakes) is widespread among humans and other primates. In laboratory conditions, nonfearful lab-reared monkeys acquire a "strong and persistent" ophidiophobia just by observing a video of a wild monkey reacting to the presence of a toy snake. The lab-reared monkeys learn to fear snakes and crocodiles when exposed to fearful monkeys on video, but when the video is spliced so that the object of fear appears to be a toy rabbit or a flower, lab-reared monkeys do not show substantial conditioning (Öhman and Mineka 6). This suggests that primates possess a "fear module ... evolved to assist mammals in defending against threats such as snakes" (7). Similar affectively charged representations, some learned and some innate, may influence our reactions to new environments: humans tend to like situations they associate with plenty and security and to dislike potentially threatening settings - this is why many people enjoy rolling hills, from where it is possible to keep an eye on potential threats, whilst few venture leisurely into swamps, where dangerous creatures could hide. But unlike other primates, humans are deeply symbolical creatures so that even "aesthetic representations of natural phenomena-paintings, descriptions, dramatic presentations, and so on are always related to our evolved preferences" (Easterlin 261). Thus, on the one hand, embedded instincts and acquired experiences modify our mental representations of physical surroundings but, on the other hand, those same mental representations shape our cultural expressions - which in turn act on and define our physical surroundings. Understanding how the human mind, literary activity and environment relate to each other could offer critical and 
educational tools helpful to erode anthropocentrism and frontier ethics. Easterlin writes that "the inclusion of human life and thought within natural processes cancels the nature-culture dichotomy, for all cultural innovations develop out of our adaptive strategies and propensities" (263). This close interdependence between physical environment, art (and literature), and the human mind reminds us that the psychological frontiers that enable the unsustainable excesses of the current industrial civilisation are all but illusory.

Moreover, Easterlin's conclusions resonate with Serenella Iovino's intuition that environmental crisis often spawns from a dysfunctional relationship between local culture and territory. Iovino explicitly articulates this concept in her essay "Naples 2008, or, the Waste Land: Trash, Citizenship, and an Ethic of Narration". There, she argues that Naples' 15-year-long emergency which climaxed in the 2008 waste crisis, "is clearly both a political and environmental issue, which in Naples more than everywhere else in Italy means a joint denial of territorial balances (sense of place) and of social interdependence (sense of citizenship). It is here that the link between citizenship and territory has been fractured" (Iovino, "Naples 2008, or, the Waste Land" 5). Raising awareness of this disconnection between citizenship and territory (and of its causes) is the precondition to addressing meaningfully the problem. Literary works could be a privileged channel to make this happen: environmentally engaged literary works "that represent the relationship between social disarray and attitudes toward physical place can dramatically deepen our understanding of our species' distrust and abuse of the material world" (Easterlin 272). As Easterlin elaborates, not only can art enhance awareness, but it also "serves as a way of coping and knowing-of exercising problem-solving skills, of imagining alternatives" (264). These are fundamental skillsets for the engaged citizen at a time when environmental problems loom large and institutions are often seen as weak, short-sighted, or even corrupt. 


\subsubsection{Ecocriticism}

The critical movement that strives to understand "the relationship between literature and the physical environment" is ecocriticism (Glotfelty). Ecocriticism is a relatively young academic discipline which started out as a self-conscious critical movement during the early 1990s, initially focusing on British romanticism and US nature writing (Buell 89). The so-called "first wave" of ecocriticism was an attempt to reorient "literary-critical thinking toward more serious engagement with nonhuman nature" and presented two main currents: a "deep ecology" movement which explored the spiritual interdependence between humans and the non-human world, and an attempt to "make literary theory and criticism more scientifically informed, meaning especially by ecology, environmental biology, and geology" (90). The latter current is still influential and two of its fundamental texts are Joseph Meeker's The Comedy of Survival (1974) and Joseph Carrol's Literary Darwinism (2004). The Comedy of Survival draws a parallel between the comedic genre and adaptive behaviour, whereas Literary Darwinism is an attempt to borrow models from the life sciences and apply them to critical analysis, and an invitation to humanists to acquire a greater proficiency in scientific disciplines. The second wave of ecocriticism began in the early twenty-first century, as international scholars with more diverse backgrounds started to join the ecocritical ranks. During this phase, the textual focus was extendend to "the whole sweep of Western literary history from antiquity to the present" and, to a lesser degree, to major non-European traditions (92). However, the differences between the first and the second waves are not limited to the latter's cultural inclusiveness. Whereas the first wave of ecocriticism "privileged rural and wild spaces", the second recognised the distinction between natural and artificial itself as a historical artefact and thus began to consider anthropised environments as legitimate objects of analysis (93). As a consequence of the shift in perception from a nature versus human dichotomy towards more nuanced forms of coexistence, the preservationist ecocentric ethos of protecting nature from human intrusion gave way to a sociocentric environmentalism advocating a transformation of urban and 
industrial landscapes. Of particular significance for this thesis is the renewed interest of ecocritics in "compromised, endangered landscapes" as well as in "marginalized minority peoples and communities both at home and abroad" (97). This interest creates a fertile theoretical ground for the analysis of literary representations of degraded territories and of the effects of such degradation on the local populations. This was the, albeit recent, past of ecocriticism.

What shape, asks Michael Verderame, will the ecocriticism to come assume? Certain trends in ecocriticism, he argues, will continue in the immediate future: the inclusion of international and transnational literatures, of genres other than so-called "nature writing", and of anthropised environments along with wilderness; but also the deconstruction of the nature-human dichotomy, and the exploration of the social, economic and physical impacts of human activities (Verderame 2-3). In addition, Verderame claims, third-wave ecocritics will need to engage with other critical traditions as well as to "learn to speak with climatologists, geologists, and physicists on their own terms", while drawing from a great variety of primary sources (3).

Building on the embryonic ecocritical work existing in Italy, I aim at highlighting how literary writing contrasts the dominant discourse that opposes Man to Nature: frontier ethics. ${ }^{1} \mathrm{I}$ explore Italian literary representations of environmental degradation with the ambition of defining their effectiveness in engendering social change, a factor that most literary scholars have taken for granted or omitted. Therefore, my research contributes to the development of the ecocritical discourse in Italy and expands the horizon of the Italian works analysed from an ecocritical point of view beyond the Calvino-PasoliniSaviano triad. The frameworks of "slow violence", "material ecocriticism" and "hyperobjects", provide a solid interpretive key to understand and analyse how

\footnotetext{
${ }^{1}$ Frontier ethics is a dualistic ideology that postulates a definite demarcation between the self-inside-subject and the outside-nonself-object. This worldview identifies the nonself as a repository of resources awaiting consumption and as a non-place to expel toxins. Whereas the self is assigned identity, vitality and agency, the nonself is constructed as unconscious, passive and inert or, if agency becomes undeniable, as evil, inferior and deserving subjugation or destruction. By defining and opposing self and nonself, frontier ethics objectifies the other thereby rationalising and facilitating violence and exploitation.
} 
twenty-first century environmentally-conscious novels encourage readers to reflect on their role within the local and global ecosystem, and realise the flaws of the current paradigm founded on the ideology of frontier ethics.

\section{Material Ecocriticism}

The foremost Italian scholar in environmental literary writing is Dr. Serenella Iovino, professor of Ethics at the Università di Torino. Iovino's Ecologia letteraria. Una strategia di sopravoivenza (2006) is the only scholarly introduction to ecocriticism written in the Italian language. Ecocriticism aims at examining what role literature "plays in the welfare and survival of humanity, and what insight it offers into human relationships with other species and with the world around us" (Meeker 4). Iovino's Ecologia letteraria is a pioneer text which for the first time in Italian academia addresses the systemic neglect of such an important aspect of what makes us human.

The first part of Ecologia letteraria is theoretical in nature and introduces ecocriticism to an Italian readership. The second part includes an ecocritical reading of Pier Paolo Pasolini's vision of culture and landscape, as well as other authors. Iovino has also published scholarly articles about the notorious problem of waste accumulation in the city of Naples, and ecocritical readings of Italo Calvino's work, especially of his Le cosmicomiche [The cosmicomics] (1965) (Iovino, "'Quanto scommettiamo?"; " Naples 2008, or, the Waste Land"; The Wilderness of the Human Other). In her "Ecocriticism, Ecology of Mind, and Narrative Ethics: A Theoretical Ground for Ecocriticism as Educational Practice", she explores the possibility that ecocriticism could be used as a means to refine perceptions about the interconnectedness of nature and society. Iovino develops Gregory Bateson's view of a cybernetic relationship between nature and culture. Within the human mind, Bateson argues, there exists a network of ideas, thoughts and emotions, which is not apart from but indissolubly $a$ part of the ecology of living forms, strictly interacting with it so that mind and nature form "an information system, an interdependent web of ecological principles", which he calls "ecology of mind". In other words, the theory of 
"ecology of mind" contends that the mind cannot be construed as separate from the ecology of living beings and in fact it is itself an ecological function which builds complex structures from simpler elements. Thus, ideas and cultures form "an information system, an interdependent web of ecological principles" which could "increase our awareness about the relationship between human and nonhuman worlds, also in terms of moral values" ("Ecocriticism, Ecology of Mind, and Narrative Ethics"' 760).

As a maturation of this preliminary intuition, Iovino has recently started to develop, in collaboration with Serpil Oppermann, an interpretive framework called material ecocriticism. "Materiality", Iovino explains,

is the condition through which bodies act with and relate with each other, shaping other bodies; it is the condition whereby the health of living beings is mirrored and mutually determined by the ecological balances or imbalances of their environments or, in other words, the condition by which a toxic place determines toxic bodies and toxic life-styles determine toxic places (“"Material Ecocriticism" 51)

Against this backdrop, material ecocriticism interprets the world as a "densely intertwined ... tissue of experience" as opposed to "a set of objective processes", and is thus a reaction both to some postmodernist and poststructuralist strands postulating a predominance of language over matter and to Cartesian mindbody dualism (Iovino, "Ecocriticism, Ecology of Mind, and Narrative Ethics" 52; Abram 143, qtd. in Iovino, "'Ecocriticism, cultural evolutionism, and ecologies of mind" 53). However, far from wholly rejecting poststructuralism, materialism proposes itself as the culmination of the "linguistic turn" by aiming "to deconstruct the language/reality dichotomy by defining a theoretical position that does not privilege either language or reality but instead explains and builds on their intimate interaction" while at the same time transcending postmodernism by drawing from an extensive array of philosophical traditions (Hekman 3 qtd. in Iovino, "Material Ecocriticism" 54). In particular, Iovino lists three sources as most influential in the development of material ecocriticism: 
Jane Bennett's Vibrant Matter (2009), Stacy Alaimo's Bodily Natures (2010), and David Abram's Becoming Animal (2011) (55).

Alaimo's Bodily Natures introduces readers to the concept of transcorporeality, defined as "movement across bodies" made possible through the "porous borders" that separate the self from the other $(2,156)$. She convincingly argues that there is no impermeable barrier between threatening and often polluted environs and what we like to call self-be it the body, the mind, the soul, or any other construct we identify with. Jane Bennett's Vibrant Matter questions the idea of matter "as passive stuff, as raw, brute, or inert" and the habit of "parsing the world into dull matter (it, thing) and vibrant life (us, beings)" therefore ignoring the vitality of matter and the lively powers of material formation (vii-viii). Vibrant matter is a reminder of how supposedly inanimate things "not only impede or block the will and designs of humans but also ... act as quasi agents or forces with trajectories, propensities, or tendencies of their own" $(\mathrm{x})$. Finally, David Abram's Becoming Animal narrates the encounter and the melding of human and non-human nature through language. It proposes a language through which it is possible "to practice a curious kind of thought, a way of careful reflection that no longer tears us out of the world of direct experience in order to represent it, but that binds us ever more deeply into the thick of that world" (Abram 3-4).

\section{Slow Violence}

Rob Nixon's Slow Violence and the Environmentalism of the Poor (2011) offers a framework which enables scholars to decode and analyse ongoing ecological disasters happening over long timeframes and where time itself contributes to erode or hide the link between violence and its causes. As I show in chapter 3 , this framework is especially relevant to the analysis of Gomorra and Delta Blues, texts which describe the short and long term consequences of unbridled industrial development on local ecologies and populations. According to Nixon, slow violence is, "a violence that occurs gradually and out of sight, a violence of delayed destruction that is dispersed across time and space, attritional 
violence that is typically not viewed as violence at all", such as "[c]limate change ... toxic drift, biomagnification, deforestation, the radioactive aftermaths of war, acidifying oceans, and a host of other slowly unfolding environmental catastrophes" (Nixon 2). Slow violence fails, by definition, to make it to the news because it consists of "scientifically convoluted cataclysms in which casualties are postponed, often for generations" (3). Complexity presents a double challenge to activist communicators endeavouring to inform the public, and who need to avoid oversimplifications as well as exaggerations while producing credible narratives. In fact, complexity inevitably allows vested interests to manufacture doubt and establish controversy, as in the decadesold struggle of Big Tobacco to compete with the "body of anti-cigarette fact", or the more recent and lavishly funded lobbying effort to "challenge the science" of climate change ("Doubt Is Our Product Memo"; Luntz 138). Even when the presence of damage becomes impossible to deny, "the contested science of damage further compounds the challenge, as varied scientific methodologies may be mobilized to demonstrate or discount etiologies, creating rival regimes of truth, manipulable by political and economic interests" (Nixon 47). However, complexity is but one factor that determines the unmarketability of slow violence. Another major challenge facing those willing to communicate this phenomenon is that it acts on levels often alien to human intuition. First, space: slow violence often happens on a scale either too small or too big for human senses to perceive. Violence is hardly perceived as such when it is perpetrated against cells and genomes of people living within the exclusion zones of industrial disasters, or when it disrupts planetary features such as the Arctic ice cover or the Amazon forest. Second, time: whereas clashing armies, terrorist attacks, or volcanic eruptions can be spectacularly captured on camera, episodes of slow violence happen in time frames too long for the hectic rhythms of the mass media, hence they are mostly ignored. Those time frames vary between the few years that separate Chernobyl's accident from the subsequent child thyroid cancer epidemic in Ukraine and Belarus, to the 25-50 year delay between $\mathrm{CO}_{2}$ emissions and the correspondent increase in global temperatures, to the 4.468 
billion years half-life of the depleted uranium (U-238) which contaminates the battlegrounds of Afghanistan, Iraq and Kosovo (Tronko et al. 879; Hansen et al., "Earth's energy imbalance" 1431). And yet, for all its unmarketability and apparent incommunicability, slow violence does have victims, and those victims do have a voice, a voice that should be heard, and not only so that they can have justice, but also so that further acts of violence can be prevented.

But how could this possibly happen in a world of sensationalised reporting? One experiment in such type of communication is doubtlessly Jeff Orlowski's documentary Chasing Ice (2012), where a number of special cameras were installed on Arctic glaciers to take time lapse pictures of the eroding ice. The resulting film compresses years of time into minutes, and tens of thousands of kilometres of prohibitive terrain within the few dozen inches of television screens, creating a dramatic and yet realistic document of the effects of global warming and thus helping the public to relate viscerally to a slow, nonlinear, worldwide phenomenon of human-induced slow violence. Of course, this capacity for narrating slow violence is not exclusive to filmmaking and, as Nixon claims,

imaginative writing can help make the unapparent appear, making it accessible and tangible by humanizing drawn-out threats inaccessible to the immediate senses. Writing can challenge perceptual habits that downplay the damage slow violence inflicts and bring into imaginative focus apprehensions that elude sensory corroboration. The narrative imaginings of writer-activists may thus offer us a different kind of witnessing: of sights unseen (15).

Narrative makes it possible to talk about the spatial and temporal dimensions beyond normal human perception as well as the complex tapestry of causality, revealing the invisible instigators of environmental crime, their motives and their strategies. Finally, framing a narrative in terms of slow violence provides a hybrid postcolonial-ecocritical framework through which it is possible to deconstruct the obfuscating and self-absolving discourses of governments and corporations. The framework of "slow violence" unravels the euphemisms 
that hide suffering and death, highlights the plight of "uninhabitants" (people whose rights and existence bureaucracy ignores because they live in officially uninhabited areas), and sheds light on invisible postbellum casualties: in sum, it allows imaginative access to realities which the dominant West-centred neocolonial narrative strives to keep peripheral to public attention (Nixon 169, 201, 275).

\section{Hyperobjects}

Timothy Morton, Professor and Rita Shea Guffey Chair in English at Rice University, provides the philosophical framework that I employ to analyse the expanded spatiotemporal scope of the two novels I discuss in the fifth chapter: "Translocality". Morton's Hyperobjects (2013) presents a new class of objects that are "massively distributed in time and space relative to humans"; these include the Sun, global warming, the biosphere, the Pacific Ocean and even "the very long-lasting product of direct manufacture, such as Styrofoam or plastic bags, or the sum of all the whirring machinery of capitalism". Hyperobjects, Morton writes, exist "relative to humans": hyperobjects are such only when seen from a certain point of view, and that point of view is unavoidably a human one (1). Therefore, the era of hyperobjects is, in reality, an apocalypse (in the real and original sense of "revelation, uncovering") of hyperobjects to humanity. Morton's Hyperobjects provides a theoretical framework that enhances the understanding of the vast and powerful phenomena that face humanity, which narratives such as Sirene and E poi la sete [And then thirst] (2011) highlight.

According to Morton, due to their nature, hyperobjects share a number of characteristics. Hyperobjects are viscous, meaning that humans cannot escape them, like the blood on Macbeth's hands, and they are completely and irretrievably immersed in them, like fish in the ocean. Second, hyperobjects are nonlocal because local manifestations of the hyperobject are not the hyperobject itself. The sea gobbling up a beach, a heat wave, typhoon Haiyan, a graph of increasing global temperatures from 1880 to today are not global warming: global warming is the single event underlying all these phenomena and 
yet global warming itself cannot be directly perceived. The temporality of hyperobjects is profoundly different from that of humans, and moreover their multidimensional nature allows them to remain latent and to manifest in unpredictable patterns. Finally, hyperobjects are interobjective, emerging and manifesting themselves in the interaction between objects and creating a mesh of relationships, feedbacks, resonances. When the wind blows in the bamboo forest, argues Morton, "[t]he wind is heard in the bamboo. The bamboo forest is a gigantic wind chime, modulating the wind into bambooese. The bamboo forest ruthlessly bamboo-morphizes the wind, translating its pressure into movement and sound" (81). The wind exists independently of the bamboo forest, and yet, if it were not for the bamboo forest, human ears would be unable to perceive it-or would perceive it in a radically different way. Thus, interobjectivity means that humans are able to perceive an hyperobject only because one of its aspects interacts with a medium which translates its fundamentally unknowable nature into consciousness.

In addition to the intrinsic properties of hyperobjects, Morton identifies and defines the emergent properties of the era of hyperobjects: hypocrisy, weakness and lameness. As hypocrites are caught in their own failure, hyperobjects reveal humanity's powerlessness. Reasoning based on either self-interest or ethics falls apart when applied to objects whose existence lasts thousands of years, Morton argues, because we cannot reasonably conceive anyone who would directly benefit from our actions. Thus, rationality enables humanity to understand the nature of hyperobjects but it is unable to offer solutions once they become problematic. In fact, whereas objects pose tame problems, hyperobjects pose wicked problems, which "one can understand perfectly, but for which there is no rational soution" (Morton 135) 2. ${ }^{2}$ Morton does not claim that reason is a worthless or obsolete tool in the age of hyperobjects but rather that it is

\footnotetext{
${ }^{2}$ The phrase "wicked problems" was formalised in a 1973 paper by Horst W. J. Rittel and Melvin M. Webster in the context of city planning but has been since applied to many other disciplines, from ecology to social sciences. In their paper, Rittel and Webster contrast "wicked" problems such as poverty with "tame" problems such as chess, puzzle-solving and mechanical engineering design, identifying the ten properties that make "wicked" problems intractable ("Dilemmas in a general theory of planning").
} 
insufficient. As a species, we are slowly but surely becoming painfully aware of this fact-and especially so as we explore the weird and contradictory universe of quantum physics - while at the same time, we seem unable to abandon a positivistic frame of reference where everything is clearly explainable and subsumed to rationality. This reveals the second characteristic emerging from the contact with hyperobjects: weakness. Weakness is a direct consequence of the dilemmas that arise when hyperobjects, which are deeply futural objects, force humanity into a relationship with beings so withdrawn (spatially and temporally) that it is hardly possible to imagine them. 3 Our relationship with beings who will live one thousand years from now is, Morton argues, exemplified in the Prisoner's Dilemma. ${ }^{4}$ Let us imagine the other prisoner as "a future self with interests so different from one's own that to some extent she or he constitutes a different self: not your reincarnation or someone else-you yourself". It is impossible for us to communicate with her or even imagine her, and yet she will experience the consequences of our choices (123). But now that hyperobjects uncomfortably force us to interact with our "other" self, how do we determine the best course of action? We cannot determine whether our alter-ego will choose to betray us, but we know that the most positive outcomes of the Prisoner's Dilemma require cooperation between subjects. Weakness provides a template for an ethical relationship with "the other", determining a course of action transcending reason and self-interest which (given the alien nature of the other) can only be a path of unconditional love.

Finally, the third characteristic that hyperobjects reveal in humanity is lameness. The Oxford English Dictionary lists the figurative meaning of lameness as "imperfectness, defectiveness", but Morton defines it as the "fissure between how we appear and what we are" ("Lameness"; Morton 196). More specifically, lameness means that

\footnotetext{
${ }^{3}$ Futurality is "the future, somehow beamed into the 'present" (Morton 91 ).

${ }^{4}$ The Prisoner's Dilemma is a classic scenario used in game theory. The police interrogate two suspects of a robbery. They cannot communicate but either can choose to confess or to stay silent. If they both stay silent, they will both get a lenient sentence. If one confesses, she goes free while the other gets a harsh sentence. If both choose to confess, they get an average sentence. The scenario highlights the benefits and the fragility of cooperation.
} 
[a]n object fails to coincide with its appearance-for another object, no matter how accurate that appearance-for. There is thus a lameness within every object, a lameness that constitutes the very being of the object as such. In order to exist, an object must fail to coincide with itself totally (196).

Rather than using the term pejoratively, for Morton it describes the insurmountable rift between perception and existence: the ontological flawedness of all that is. Astronomers observe the fossil light of stars which may have died billions of years ago. The Sun-for-Earthlings is the Sun-as-itwas-499-seconds-ago. Such reasoning may sound academic, but it does have practicality: when NASA's Curiosity rover entered the Martian atmosphere, the landing had to be completely automatised, because it took 7 minutes for radio waves to reach the lander. Atoms shake, and subatomic particles vibrate in and out of existence even in apparently immobile objects. Objects fail to coincide with their appearance-for us because our imperfect senses are bound to perceive the past by unconquerable physical limits. Lameness means that objects exist in a continuous flux over which we have little or no power, a concept remarkably similar to the Buddhist anicca.5 As viscous hyperobjects permeate humanity, they ruthlessly change it, they hybridise it into something new and uncanny, leaving no aspect untouched: "humans find nonhumans pressing in on all sides, in the charnel ground at the end of the world" (Morton 196). At the same time, objects are irretrievably separated from each other, able to perceive only the limited outward manifestation of the other-guaranteeing that the real nature of the other remains forever unknowable. Although it is possible to perceive the temporary and ever-changing manifestations of hyperobjects, humans can never directly perceive them as their essence is withdrawn from the sensory (196). As a consequence, problems posed by hyperobjects resist traditional approaches and are thus unlikely to be addressed unless humanity undergoes

\footnotetext{
${ }^{5}$ In Buddhism, anicca, one of the three marks of existence, is the quality, shared by all conditioned phenomena, of being subject to change and therefore unreliable, a source of frustration and suffering. Anicca is a Pali word composed of the term nicca, meaning "continuity" or "permanence" and the privative prefix $a_{-}$.
} 
a paradigm shift in how it relates with the other. The era of hyperobjects spells death for "individualism, nationalism, anti-intellectualism, racism, speciesism, anthropocentrism ... Possibly even capitalism itself" (21). In his Edifying Discourses, Kierkegaard argued that "against God, we are always in the wrong"; and so we are against hyperobjects (Søren Kierkegaard qtd. in Morton 154). The very nature of hyperobjects indicates that they cannot be conquered, defeated, or destroyed but only granted the same reverential awe once accorded to divinity, whether the hyperobject in question is global warming, nuclear waste or the biosphere.

To summarise, material ecocriticism reveals the illusory nature of the frontier between the self and the nonself which enables many destructive manifestations of modern society. Material ecocriticism acts by deconstructing this frontier and by developing awareness of the complex interactions and of the interdependence between humans, non-human living beings and matter. Furthermore, by highlighting the interconnected nature of reality, material ecocriticism invites reflection upon the long-term consequences of everyday actions. Violence is as essential a manifestation of frontier ethics as it is noxious but whereas much has been written on various aspects of direct violence, I am going to focus on how environmental literary writing highlights and engages with the less investigated problem of slow violence. Indeed, the writer's toolbox is full of instruments that can summon the power of imagination to boost the limitedness of the senses and introduce readers to aspects of industrialisation which, by accident or purpose, have been kept away from plain sight. In particular, the metaphor becomes a primary tool to help readers connect with the complex reality of events of slow violence. Finally, reading texts under the framework of hyperobjects provides a solid philosophical foundation that enables readers to make sense of complex realities such as global warming, ozone depletion and nuclear radiation. These temporally and spatially vast phenomena comprehensively refute humanity's imagined supremacy over the non-human: whereas hyperobjects are invisible to the unaided vision, the narrative lens can display their mechanics and their properties, thus presenting itself as an invaluable tool to understand the 
extended reality that lies beyond the our limited senses.

\subsection{Theoretical Approach}

Giacomo Leopardi imagined Nature as a gigantic woman who hardly took notice of human affairs ("Dialogo della Natura e di un islandese") (1918). In the twentieth century, this image morphed into that of a wounded organism (see section 1.4). Climatologist Wallace S. Broecker famously remarked that "[ $t]$ he climate system is an angry beast and we are poking it with sticks" (Stevens). Nature could next metamorphose into a monster which humanity needs to keep forever sedated in order to avoid destruction.

What to do? Some proposed approaches only attempt to solve problems caused by frontier ethics through a more radical application of the same methods. However, a definition of insanity is doing the same things over and over again while expecting different results. I will compare and contrast a technological approach to a facet of global environmental change with a educational approach, in order to highlight the possible role of the Humanities in the current ecological crisis.

As carbon emissions rise unchecked through lack of leadership and connivance of the world's governments with business (see section 1.2), astronomer Lord Martin Rees, former President of the Royal Society, recently called for the development and deployment of geonegineering technologies. Lord Rees believes that "[h]acking the planet" would be achieved by using aeroplanes to spray chemicals in the stratosphere that increase albedo and thus control the Earth's temperature, a technology known as Solar Radiation Management (SRM) (Jha). SRM was the technique that Nobel Prize winner and atmospheric physicist Paul Crutzen described when he broke "the taboo on geoengineering" (Crutzen; Hamilton, Earthmasters 15). But Lord Rees and Paul Crutzen are not alone in believing that humanity will have to control the global climate. A 2009 poll by the Independent shows that 54 per cent of climate scientists believe that "the situation is now so dire that we need a backup plan 
that involves the artificial manipulation of the global climate to counter the effects of man-made emissions of greenhouse gases" (Steve Connor). Lord Rees readily admits that the idea is a "political nightmare" and there is a possibility for "unintended side-effects" including a radical modification of regional weather patterns, worldwide droughts, ozone depletion, acid rains, disturbance of the monsoons and more (Jha; Robock et al. 2; Trenberth and Dai 4). SRM would only be able to control one of the effects of an excess of GHGs in the atmosphere, the increase in temperatures, while doing nothing to prevent the acidification of the oceans (see section 1.1) (Jha). Lord Rees also admits that SRM would have to be continued indeterminately as "the warming would return with a vengeance if the countermeasures were ever discontinued" (Jha; Hamilton, Earthmasters 65-67). Finally, its masking effects could even dissuade world leaders from the necessity of reducing carbon emissions and reinforce the idea that humanity's manifest destiny is domination over nature (Robock 17 ; Hamilton, Earthmasters 67; Jamieson 332).

\subsubsection{The Premises of Cultural Hacking}

"Planet hacking" could well be an inevitability, with some expressing an interest in the complete control of the Earth's climate to suit the desires of "those who turn the knobs" (Salter; Hamilton, Earthmasters 108-109). Given that the term "planet hacking" is widely used in the media as a synonym of SRM, it pays to understand the semantic implications which are attached to this association. The Oxford English Dictionary defines "to hack" as, "[t]o gain unauthorized access to (computer files, etc., or information held in one)" ("To hack"). However, the verb "to hack" has a slightly different meaning among computer scientists. Brian K. Harvey, lecturer of Computer Science at Berkeley, defines a hacker as "someone who lives and breathes computers, who knows all about computers, who can get a computer to do anything". Although the general usage of the verb "to hack" approximates the definition that the Oxford English Dictionary provides, and while the idea of gaining unauthorised access 
to Earth systems may well fit the description of SRM, I use it in the way Brian $\mathrm{K}$. Harvey proposes, as the effort of an expert to produce an "aesthetically perfect" result on an artificial system, where aesthetic means elegantly functional ("What is a Hacker?"). Applying the metaphor of hacking to the deliberate modification of weather patterns sheds light upon a fundamental assumption that geoengineering enthusiasts support, that is, the idea that natural chaotic systems can be fully understood and controlled through empirical methods. But in fact, this is impossible: trying to predict chaotic systems we face "predictive hopelessness" because "knowledge of initial conditions is only enough to give us predictions with an enormous spread of uncertainty" (Kellert 32). Thus, on the one hand, hackers know the ins-and-outs of the system they are trying to modify, and act on predictable and replicable environments. On the other hand, the climate system is unlike a computer program, or a laboratory experiment, where initial conditions can be accurately determined and controlled. The realisation that billions of lives depend on the successful outcome of such reckless experiments should give us pause for thought.

In contrast to these calls to clumsily "hack the planet", I propose hacking the dominant cultural paradigm which seeks domination over nature as an alternative solution to the global environmental crisis and I suggest that culture provides a more appropriate medium for hacking. This proposal stems from the realisation that the cause of the problem we are facing lies with the current dominant cultural paradigm rather than in the natural order of things. Therefore, it is more appropriate to modify culture instead of attempting to force the global ecology into submission in order to accommodate a cultural paradigm which has already proven itself deleterious. Unwisely tampering with ecological systems is bound to result in permanent damage to fundamental ecosystem services that humans and other species share, and in irreparable losses for which there is no technological replacement.

In 2002, Republican strategist Frank Luntz wrote in a notorious memo to US President George W. Bush that "[a] compelling story, even if factually inaccurate, can be more emotionally compelling than a dry recitation of 
the truth" (132) 6 6 Although the ambition of Luntz's memo was to weaken environmental legislation through deliberate emotive manipulation, it is undeniable that such a strategy was effective. The memo shows that Luntz was well aware that stories build what we are, how we see the world, and how we act in it. Each society conceives its own myths, and these stories determine political, religious, scientific, and economic discourses which, in turn, build a society's characteristics, worldviews, and laws. In so doing, myths shape societies' relationships with their environment. A society whose myths praise domination upon others and upon nature will develop a worldview whereby domination and exploitation become normal, justified and necessary. By contrast, societies exist whose myths highlight the interdependence of all beings with their ecosystems, encourage sustainability, and reprehend ecologically unsound behaviour. Such societies are likely to flourish in balance with their surroundings. Thus, by hacking the cultural paradigm, I mean educating current and future generations about the interdependence of living beings and about the overriding necessity to preserve working ecosystems.

There are several reasons why this research aligns itself with the humanist approach of engaging with environmental problems. First of all, modifying the cultural paradigm does not require deploying an extensive industrial infrastructure and can be achieved through educational approaches similar to those already in place to foster gender equality and anti-racism (Plumwood 134). The second advantage of modifying a culture over manipulating the biosphere is that it would be infinitely safer and result in fewer side-effects. Modifying human culture poses no risk of exacerbating droughts, depleting the ozone layer, or causing acid rain and in fact it has been safely been done from times immemorial. Unwanted effects would cause limited damage and be relatively easy to reverse. There would be no risks for militarisation or of causing international conflict, and no ethical quandaries to navigate. There would be little concern that efforts to modify a cultural paradigm could turn

\footnotetext{
${ }^{6}$ This is also the conclusion that Dan and Chip Heath reach in their book, Made to Stick: Why Some Ideas Survive and Others Die (2007).
} 
into multinational monopolies prioritising profit over the well-being of millions. Finally, and most importantly, hacking the culture addresses the very causes of the current environmental crisis and its benefits would continue long after humanity will have understood and enacted its role within the global ecosystem.

This type of education needs to have scientific foundations because it needs to lie on an understanding of how the biosphere works. However, it would differ from mere scientific knowledge as it should also guide learners to appreciate what the disciplines of ethics and justice have to teach about redesigning our relationship with the other. Stephen Gardiner has called global warming "a perfect moral storm" which "involves the convergence of a number of factors that threaten our ability to behave ethically" and whose dimensions conspire to create ideal conditions for inaction because of a clash between the individual rational interest and the collective rational interest (398). Thus, it is apparent that international efforts towards the reduction in GHG emissions have stalled because of the failure to engage meaningfully with the public about the ethical questions connected with global warming in particular and ecological issues in general (see section 1.2). Global warming as well as policy choices entailing GHG reduction necessarily impinge upon almost every aspect of modern life and it would be unthinkable for democratic (and even less-than-democratic) governments to act without popular support. Because obtaining social licence for action is fundamental, it is imperative to create a generation of leaders who are scientifically educated as well as aware of the ethical implications of the great ecological challenges of this century.

What could be the contribution of the Humanities toward such an epochal shift in awareness? I propose utilising the tools of ecocriticism within an educational or social context to analyse literary texts possessing the characteristics enumerated in section 2.2. Such analysis should be aimed at debating as a community the ethical issues which the selected narratives highlight and providing a platform for the introduction of concepts related to the discipline of environmental ethics. Serenella Iovino briefly mentions such a possibility in her paper, "Ecocriticism, Ecology of Mind, and Narrative Ethics". 
She proposes two complementary pathways through which ecocriticism and literature can be used as a means to enhance ethical awareness and political inclusivity: the first looks directly at the theory of "ecology of mind", introduced in section 2.3.2, and the second builds a narrative ethics upon this intuition. If we consider texts as crystallised ideas, we realise that they form complex feedback loops where the text acts on the world, and the world acts on the text. Subsequently, a "narrative ethics" can be developed upon the theory of ecology of mind. In particular, Iovino argues that stories can be used to develop a number of social skills as well as to promote a personal "discourse of values":

Narratives are potentially apt to raise our responsiveness about values and responsibilities (whether 'environment-society,' or 'human-nonhuman') and envision strategies of change. By telling a story, narratives not only influence our understanding of a given reality, but also creatively enable a project that takes on society and its values. In other words, by inspiring awareness, narratives are a creative form of ethical responsibility, and the object of the story turned into a moral (and therefore political) project ("Ecocriticism, Ecology of Mind, and Narrative Ethics" 761 ).

Thus, while few would dispute its value as entertainment, I suggest that literature at its best can be much more than escapism or self-referential intellectual exercise: a more reasonable point of view would be that, in literature, aesthetics and ethics are indissolubly interwoven (see Appendix B "Intervista a Laura Pugno").

In his essay "On some functions of literature", Umberto Eco argues that literary writing contributes to one's sense of identity and community. Those who grow up without literature sever themselves from a "world of values that stems from and sends us back again to books" (4). Furthermore, Eco explains that literature, by postulating facts, allows a straightforward verification of one's grip on reality. A flawed reading exposes individual idiosyncrasies when it contradicts or extrapolates meanings that the text does not contain (7). Literary 
texts have "the power to shape the destinies of human societies": emotionallycharged fictional events and characters live in the mind of their readerships creating and powering "a cultural habitus, a social disposition" (10). Finally, Eco argues that stories teach us how to face ineluctability as well as how to understand our limits without falling into despair. Global ecological problems like global warming are irreversible, but that "does not mean unstoppable" (Archer). A fine balance between unwarranted optimism and apathetic fatalism is needed, which we should learn from stories that "teach us how to die" (Eco 13).

\subsubsection{The Tasks of Mourning}

Many environmental problems belong to the category of "commons dilemmas". Commons dilemmas are problems whose solution is hindered by the fact that all actors have an interest in continuing to behave in a way that is detrimental to the community. For example, in an unregulated shared fishery, each fisherman has an immediate economic incentive to catch as much fish as possible, even though such behaviour will in the long run deplete the fishery and result in the collapse of the fish stock. Another example is global warming in a fossil-fuel based economy. Growth has been so far tightly coupled with energy consumption: most economic activities depend on producing GHGs because fossil fuels are the cheapest form of energy. Virtually all modern economies act in the pursuit of growth, and thus economic actors tend to disregard the consequences of increased emissions, which contribute to exacerbating the problem of global warming, ultimately imperiling the whole global economy. A notable corollary of the commons dilemma is that a single virtuous actor cannot break the vicious circle. In the fishery scenario, each fisherman is aware that withdrawal from the fishery would only result in competitors accessing their quota. Likewise, it is easy to dismiss individual efforts to reduce greenhouse gas emissions as useless but at the same time it is apparent that global warming has been caused by the summation of individual carbon emissions. 
The nature of these environmental problems promotes disengagement and a feeling of powerlessness in the public. The main reasons for the lack of meaningful action in relation to global warming are "heightened perceptions of powerlessness and the commons dilemma": the individual feels that efforts towards mitigating one's impact are costly and amount to little, and therefore opts to ignore the problem and possibly falls into denial (Aitken, Chapman, and McClure). So far, only a minority of individuals are free from such dissonance. Another minority resists or ignores the facts of climate science, while the majority "seems mainly to use maladaptive coping strategies" (Hamilton and Kasser 2). These maladaptive socio-psychological mechanisms aim at overcoming the painful effects of dissonance when faced with the depiction of future high-impact scenarios (Stoll-Kleemann, O'Riordan, and Jaeger). Evidence shows that most people realise that environmental problems are serious, but have not been empowered to solve them. Eventually, they embrace denial as a short-term strategy which enables them to cope with the guilt and fear associated with inaction.

Because denial is an inability to accept loss, learning to mourn would act as an antidote to these psychologically and socially destructive behaviours. To achieve this, psychotherapist Rosemary Randall proposes the creation of forums where individuals can freely express their grief and anxieties in a supportive environment as well as discuss their responses to global warming (126). Such an environment would be conducive to reflection and self-inquiry, would greatly facilitate the process of mourning for a "paradise lost" and perhaps encourage the rebuilding of a more sustainable society from compassionate and rational premises. Sigmund Freud developed the first models of mourning, but many have since improved on his work. All models are designed to help the ego to detach itself from the lost object. Of the several models available to address loss, Randall believes that James William Worden's is the most appropriate to deal with ecological loss (121). In his book Grief Counseling and Grief Therapy: A Handbook for the Mental Health Practitioner (2009), Worden defines mourning as a process which comprises four main tasks: 
1. Accepting the reality of the loss;

2. Processing the pain of grief;

3. Adjusting to a world without the deceased;

4. Finding an enduring connection with the deceased in the midst of embarking on a new life (40-53).

Mourners continually oscillate between embracing these tasks and engaging in "avoidant emotional coping" (AEC), which provides brief respite from the pain but no actual long-term benefit. AEC strategies include blaming, distraction, and denial (Worden 66). Randall's adaptation of Worden's model of mourning to the challenges of global warming distinguishes four types of loss, all of which are intrinsic in the current environmental crisis:

1. Absolute: loss the individual has no control over. It is now clear that the ecological crisis is well underway, that much damage has already been inflicted on previously pristine ecosystems, that extinctions are forever and, finally, that it could take thousands of years for the climate system to revert to a stable state;

2. Chosen: renunciation, selflessness. Although mitigation strategies could be painful in the short term, they are key to minimising future ecological and social impacts of the current environmental crisis;

3. Transitional: moving to a new stage of life. Adaptation to the ecological shift towards a less hospitable Earth necessarily implicates a social shift towards forms of government that can cope with such a profoundly modified ecosystem;

4. Anticipatory: grieving for future loss. Much environmental and social damage due to an unbalanced biosphere is now unavoidable: for example thermal inertia determines that global temperatures and sea levels will continue to rise for decades even if anthropic GHG emissions were to cease 
today (Intergovernmental Panel on Climate Change, "'Climate Change 2001: Synthesis Report"; Randall 124).

Learning to live within the limits of the natural world represents a multifarious challenge awaiting humanity. In his book Eaarth (2010), Bill McKibben argues that human activity is already in the process of modifying the Earth that was humanity's cradle. The Earth we inhabit is quite a different place from the one we thought we lived in: it is an Earth-like planet that has lost many of the benign features that humanity has taken for granted for millennia (McKibben 3). If we are to survive on this new planet, we need to slow down, stop and reverse the course of degradation that has been the norm after the industrial revolution. We have to learn to mourn what the Earth has irretrievably lost to acknowledge that value comes from limitedness. We have to mourn and abandon the aspects of our lifestyles that are incompatible with the long-term prosperity of humanity. We have to mourn our lost innocence through understanding our species' impact on the global ecosystem and, on the other hand, our naïve hopes to dominate nature through technology. We have to mourn our "understanding of the how the future will unfold", including the future imagined for the next generations (Hamilton and Kasser 6). Finally, we have to mourn the things that will change no matter how quickly we rise to the challenge, and we need to realise that courageous and radical choices are necessary.

\section{On Narrative Catharsis}

In her paper, "Loss and climate Change: The Cost of Parallel Narratives", Randall explicitly advocates the use of narrative to aid mourners in their journey: "[p]roviding role models and stories is well-known as a powerful way of communicating and providing points of identification for diverse audiences" (126).

Greek playwrights wrought their stories of gods and men to elicit deep emotional responses in their public. Their aim was to educate as well as to entertain, and they achieved such a feat through a skilful personification and 
actualisation of emotive and physical forces (Stafford 71-85). Among them, Aristotle first identified a mechanism that could "purify" the human mind in his Poetics: catharsis was the "purging of the spirit of morbid and base ideas or emotions by witnessing the playing out of such emotions or ideas on stage" (McKeon 1458). More recently, Freud and Breuer defined catharsis as a physical reaction through which "affects are discharged" (8). Finally, the American Psychological Association defines catharsis as "the discharge of affects connected to traumatic events that had previously been repressed by bringing these events back into consciousness and reexperiencing them" (156). Catharsis operates in at least two ways. On the one hand, it shows the pernicious effects of excess and induces the audience to avoid extremes of cynicism and emotivity (Lucas 23). On the other hand, exposure to mimicked emotions teaches audiences to better recognise and cope with their own impulses when they arise (Belfiore 260). The mechanisms that drive catharsis are unclear but the cathartic effects of reading stories are well-documented in scientific literature. Jemèljan Hakemulder finds evidence that patients of bibliotherapy "come to recognize their repressed emotions, and thus make the first step in learning to deal with them", an assertion which a number of related studies support (Hakemulder 16; Gross; Scheff; McClaskey; Cutforth).7By stimulating focused thought, stories help the reader to eschew avoidant emotional coping, to articulate repressed painful feelings, and to consciously process pain and grief. Exploring one's own reaction to environmental degradation allows the resurfacing of repressed feelings to consciousness, opening the doors to a cathartic process of mourning, and eventually to empowerment, which provides an antidote to powerlessness and denial. This awareness encourages readers to rise to the further challenges presented by the tasks of mourning and to access the healing that this process entails.

\footnotetext{
${ }^{7}$ Bibliotherapy is defined as "a process of dynamic interaction between the personality of the reader and literature - interaction which may be utilized for personal assessment, adjustment, and growth" (Lehr 76-79).
} 


\section{In Practice: The Death of the Old One}

Randall notes that,

[t]here is frequently an assumption that the stories must be positive and hopeful if they are to succeed and that famous people are necessary to make the point. They tend to present end-points, rather than processes - a film-star getting on a bus or a rock-musician digging his vegetable patch, for example.

She argues, however, that it would be more effective to utilise stories which focus "on the process of change, including the experiences of loss and grief" (126). Successful stories should enable the readers to safely explore their emotive reaction to witnessing ecological destruction without feeling overwhelmed and powerless. At the same time, they should not sensationalise and trivialise important issues. Thus, educators wishing to use narratives to introduce a discourse about environmental ethics and responsibility should utilise stories which avoid both the extremes of Pollyannaism and hopeless despair, while constructing a path that conjoins the readers' here-and-now with a future which they can perceive as both desirable and possible.

Let us see how the narratives that I have elected to analyse fit into this template. The first characteristic of these narratives is that they should reflect real ecological problems (see section 2.2). This is a prerequisite to guaranteeing that any emotive reaction that readers may experience is triggered by realistic perceived threats, and that the subsequent catharsis will provide genuine psychological benefits in real-world situations. In addition, stories which report (either realistically or metaphorically) real ecological problems are more likely to succeed in connecting with the reader's here-and-now simply because they speak about the same reality.

As Wu Ming explain, a common mythologem in NIE works is "la morte del Vecchio" [the death of the Old One]:

[m]olti dei libri che ho definito "New Italian Epic" trattano del buco lasciato dalla morte di un "Vecchio", un fondatore, un leader 
o demiurgo ... elaborano il lutto, usano la commistione di autofiction ed epica per avviare una terapia. Immaginando storie alternative, curano i difetti del nostro sguardo di postumi e ci preparano a immaginare un futuro [many of the books that I have defined "New Italian Epic" narrate the void left after the death of an "Old One", a founder, a leader, or demiurge ... they elaborate the mourning, use a mixture of self-fiction and epic to begin a therapy. Through imagining alternative stories, they heal the flaws of our posthumous gazes and prepare us to imagine the future] (Wu Ming, New Italian Epic 74-75).

Randall claims that narratives most suitable to guide readers through the tasks of mourning should allow for a spontaneous emersion of repressed emotive forces and link the present with a future that they create dynamically. Likewise, Wu Ming 1 finds that a recurrent theme within NIE narratives is the death of the Old One, and the subsequent attempt to accept death, readjust to loss, and acquire strength and experience from the event.

This "Old One" takes many forms in narratives addressing environmental degradation, and it is often not a person but something that had been taken for granted in Italian culture, so much so that nobody noticed its demise. Realising the loss is the first task of mourning, and processing the pain and grief is the second. Narrative can offer guidance and support along this troubled path.

\section{On Bypassing Avoidant Emotional Coping}

There are multiple mechanisms through which stories that provide factual or metaphorical representations of environmental degradation and of their causes can be used to stimulate debate and awareness about environmental issues, as well as to elaborate effective coping and adaptation strategies. First, stories can provide multiple subjective perspectives about environmental issues. Some may be factual, others may be less so but, regardless of their accuracy, they stimulate readers' interest and encourage them to investigate the facts and their implications on their own terms. More importantly, stories 
enable readers to develop a strategy for mourning. It has been established in section 2.4.2 that individuals adopt AEC strategies because they lack an emotive and behavioural framework enabling them to integrate information about environmental degradation into their existing worldview. Because these inputs threaten the internal narrative of some individuals, they are rejected. As John K. Galbraith remarked, "[f]aced with the choice between changing one's mind and proving that there is no need to do so, almost everyone gets busy on the proof" (50). However, because narrative offers metaphorical and hypothetical scenarios instead of hard facts, and because readers engage in a "willing suspension of disbelief", stories effectively bypass this psychological hurdle. Instead of pressing readers to accept new information that they may be unable to process, stories ask "what if" questions and thus offer the tools to build a new internal narrative. In fact, in a story, the question is not about whether the scenario being introduced is real or not (although it matters whether it is convincing or not). Narrative allows individuals to explore their own emotive reaction toward the described scenario regardless of its factuality and learn about possible strategies to deal with loss. At a second stage, with the help of peers and mentors, narrative analysis promotes the conscious examination of the individual emotive reaction, and enables the translation of this analysis into a set of shared ethical guidelines. This ethical priming is likely to influence the ideas and behaviour of the individual once they are be exposed to similar narratives, this time from news reports or other non-fictional sources. They thus provide a framework which allows these individuals to overcome powerlessness and develop a meaningful and effective response to the threat.

\section{In Practice: Exploring Uchronia}

In the previous section I have explained how stories could help individuals to create effective personal narratives that empower them through the challenge of abandoning obsolete and harmful ideas and reconstructing a new worldview based on a reviewed relationship between humanity and its habitat. In short, stories manage to bypass AEC mainly because they encourage readers to 
abstract themselves from objectivity and thus allow the creative forces of imagination to take over.

Perhaps some of the stories most suitable to accomplish this task are those which can be defined as "uchronias". Uchronia is a portmanteau which Charles Renouvier coined in 1876 by fusing the words utopia (Greek: $u$-topos, noplace) with chronos (Greek: chronos, time), to mean "no-time". Uchronias pose a "what if" question, and from this premise the author constructs an alternate universe which readers are bound to find both very familiar and radically different $]^{8}$ Because of this focus on one single question, they could be suitable to introduce definite aspects of an issue and explore their ethical and factual ramifications. However, according to $\mathrm{Wu}$ Ming, one of the shared characteristics of many NIE novels is that they are, in fact, potential uchronias: "non fanno ipotesi 'controfattuali' su come apparirebbe il mondo prodotto da una biforcazione del tempo, ma riflettono sulla possibilità stessa di una tale biforcazione, raccontando momenti in cui molti sviluppi erano possibili e la storia avrebbe potuto imboccare altre vie" [they do not create 'counterfactual' hypotheses about how a world would appear after a bifurcation of time, but reflect on the very possibility that such bifurcation could take place, telling moments where many developments were possible and history could have taken other courses] (New Italian Epic 35). That is, stories which unveil hidden potential scenarios remind the reader that freedom of choice exists and thus highlight the possibility that there are indeed infinite alternative ways to imagine the future.

\subsubsection{Opening New Perspectives}

One reason environmental problems are intractable (as epitomised by global warming) is that those who cause them are usually the least affected, whereas it is the unborn, the powerless and the voiceless who pay the consequences of

\footnotetext{
${ }^{8}$ Perhaps the best-known uchronia is Philip K. Dick's The Man in the High Castle, which describes an alternate universe where the Nazis won World War II. An example of uchronia in Italian literature is Wu Ming 5's Havana glam (2001), where David Bowie is a communist sympathiser living in Havana.
} 
the degradation. Future generations, people living in less developed countries, animals and ecosystems are all powerless to affect the polluters' choices and less able to shield themselves from the effects of pollution. Stefan Skrimshire asks in the introduction of his Future Ethics, "how do we create the means to empathise with people we may never meet, in a future we may never inhabit?" (9) The answer may lie in a sense of connectedness with the other that the current consumerist paradigm has all but demolished. In his essay titled "Proposal for a Revolution of Human Relationships", Roman Krznaric argues that "perspectivetaking is one of the most important ways for us to overcome our assumptions and prejudices about others": a bridge across the abyss that separates the polluter from the victim of pollution (156). However, in his Requiem for a Species, Clive Hamilton goes further than that, arguing that in order for humanity to outgrow its exceptionalism, it would be desirable to extend this connection to non-humans through the development of "metapersonal selfconstrual", which allows the individual to experience him or herself as part of an ecosystem rather than as a separate entity (Requiem for a Species 154). A sense of connectedness with a wider cosmos would effectively inhibit any propensity to destructive behaviour because the reformed individual would identify the damaged party with the self.

\section{On Empathy}

The deleterious effects of pollution are often invisible to those who are most responsible for them. As Stephen M. Gardiner argues, "the responsibility for historical and current emissions lies predominantly with the richer, more powerful nations, and the poor nations are badly situated to hold them accountable" (402). Not only this but, according to the World Bank, poor nations are also likely to bear the brunt of global warming because of restricted adaptation choices (F. Harvey). The first step toward limiting environmental damage is that empowered and affluent individuals understand the mechanisms though which certain apparently innocuous behaviours are bound to cause grief to vulnerable populations as well as to ecosystems. To this effect, it is 
necessary to disseminate basic concepts of environmental ethics so as to cause ecologically harmful behaviour to become as unacceptable as sexual and racial discrimination. What type of advantage would targeted narratives offer in introducing the often controversial discipline of environmental ethics?

A number of experiments have been conducted to determine whether reading affects readers' understanding of other people's behaviour, thoughts, emotions-in other words, whether reading contributes to the development of empathy under experimental conditions. In Empathy and the Novel, Suzanne Keen observes that researchers wishing to establish the effects of empathy on readers should tread lightly because the impact of narratives on readers "is considerably more unruly than advocates of narrative ethics would lead us to believe" (68). However, at the same time, she finds that reading can create an emotional bond between the reader and a more or less imaginary character thus rendering him or her and the world he or she inhabits a little truer for the reader, a little nearer to his or her own reality (70). Readers have often suspected that narrative allowed them to connect on an almost physical level with fictional characters and that reading novels elicited deep changes in the ways they see the world. However, because such intuitions were based on no more than anecdotal evidence, skeptics were able to categorise such beliefs as no more than wishful thinking or, worse, as a self-serving discourse meant to redirect more academic funds towards the cash-strapped Faculties of Humanities.

Since neuroscientists have begun to focus their attention on the effects of novel-reading, such skepticism has been harder to maintain. Research in the field of neuroscience suggests that reading novels does indeed significantly affect the mind in more than one way. Functional magnetic resonance imaging (fMRI) is an important tool used in neuroscience to gauge neuronal activity by measuring changes in blood flow in different areas of the brain. Because blood flow and neuronal activation are coupled, increased regional blood flow indicates enhanced neuronal activity. Berns et al. have recently published a study where fMRI was used "to track changes in resting-state brain activity on a daily basis over a period of three weeks, during which individuals read 
a complete novel" (590). In their experiment, Berns et al. recruited a total of 21 individuals and subjected them to daily scans for 19 days. The first five days and the last five days were, respectively, "wash-in" and "wash-out" periods, where brain activity was scanned while subjects were at rest. During the evening of each of the middle nine days, subjects were expected to read one-ninth of Robert Harris' historical novel Pompeii. Researchers chose this particular novel because it was "based on true events but written as historical fiction and conveyed in a classic narrative arc", which is significant to this thesis because these are characteristic shared with many of the novels I analyse (592). As expected, fMRI scans showed evidence of short-term arousal of three independent neuronal networks connected to language processing as a result of the novel (597). However, researchers also detected enhancements in somatosensory and motor regions which remained elevated in the washout days. According to Berns et al., this may be explained because "reading a novel places the reader in the body of the protagonist, which may alter somatosensory and motor cortex connectivity" (59). Another study aptly titled "Reading Literary Fiction Improves Theory of Mind" was recently published in the journal Science. In their paper, David C. Kidd and Emanuele Castano tested volunteers with five experiments gauging different aspects of the subjects' theory of mind (ToM). Researchers found that literary fiction engages the psychological processes needed to gain access to characters' subjective experiences and this process of engagement stimulates readers to refine their ToM. First of all, literary fiction provides an environment where readers can safely "consider the experiences of others without facing the potentially threatening consequences of that engagement". More importantly, because fictional characters often act in ways that disrupt our expectations, "[r]eaders of literary fiction must draw on more flexible interpretive resources to infer the feelings and thoughts of characters" (Kidd and Castano 378).

Keen suggests that literary identification happens more readily "for negative feeling states," which is a particularly important detail when the target narratives depict bleak scenarios of environmental decay and the tragic effects of such degradation on individuals and societies (71). Similarly, in his 
review of the scientific literature, Jèmeljan Hakemulder finds that complex narrative could be used to help readers bridge cultural differences and develop empathy, although it is unclear whether this increased understanding enhances altruistic behaviour $(13,36)$. Hakemulder's own research also finds that "a narrative presentation causes stronger effects on our beliefs about the emotions and thoughts of others (social perception) than a non-narrative presentation with approximately the same contents" (107). Batson et al. reach a similar conclusion: in their experiment, test subjects were divided into three groups and exposed to an interview with a drug addict. Group I was composed of individuals scoring low on empathy tests who were asked to take an objective stance toward the interviewed character. Group II and III were people scoring high in empathy who were asked to imagine how the interviewed character felt. However, whereas subjects of group II were informed that the interview was fictional, those in group III were not. Results show that subjects belonging to group II (high-empathy / fictional) developed only marginally less empathy than group III (high-empathy / non-fictional) towards the interviewed character. In addition, both group II and group III test subjects reported an improved positive attitude towards people suffering from drug addiction compared with group I (low-empathy) (Batson et al. 1661-1662). Batson et al. conclude that "inducing empathy for a fictional character can be used to improve attitudes and stimulate concern for a stigmatized group" (1666). Yet another element which could promote the development of empathy is slow-reading. It has been observed that it takes at least 30 seconds for an empathic response to take place in the reader. Research shows that "readers who are made believe [sic] they are dealing with a literary text rather than a newspaper article or popular romance novel, will read significantly slower" and that empathy arises more effortlessly in subjects who routinely make use of such skills (Hakemulder 74; Feshbach). In contrast to rapid mass media stories, the slow and deep reading skills necessary to process literary texts seem particularly suitable for the development of empathic responses.

Studies show that reading narrative enhances empathy, that is to say, the 
understanding of the workings of the human mind. Evidence also shows that, although the link between reading and altruistic behaviour is subtler, narrative affects attitudes towards outgroups, and it is possible that empathy could be also extended toward non-human living beings. Narrative offers an opportunity to sharpen feelings which consumer society has blunted with its celebration of individualism. Likewise, narrative offers an opportunity to widen readers' empathic horizon, and to overcome the cynicism and detachment that characterise some strands of postmodernism. There is no conclusive proof that cognitive empathy promotes pro-social behaviour. However, empathy is certainly a precursor to understanding the intricate interdependence web which links the self with other humans and humans with other living beings.

Without understanding of the other, there can be no understanding of relationship, which is necessary to develop a heightened awareness of the processes that disrupt the global ecosystems and thus threaten the well-being of humanity. Such understanding is necessary to create a new cultural paradigm.

\section{In Practice: Gazing Obliquely}

Wu Ming prospects a resurgence of a literature able to evoke indignation towards injustice, mourning of loss, and empathy for those who suffer (New Italian Epic 25). To achieve such objectives, NIE brings to its extreme consequences the act of feeling and experiencing reality from different points of view. Wu Ming identifies in a "sguardo obliquo" [oblique gaze] one of the main characteristics of NIE: the oblique gaze is "un'intensa esplorazione di punti di vista inattesi e inconsueti, compresi quelli di animali, oggetti, luoghi e addirittura flussi immateriali" [an intense exploration of unexpected and unusual points of view, included those of animals, objects, places and even immaterial fluxes]. It is important to note that the oblique gaze is not Wu Ming's invention and indeed features in novels which predate NIE. For example, as Iovino argues, the main character of Italo Calvino's Cosmicomiche, Qfwfq

è nebulosa, è semplice aggregato di materia primordiale, è un dinosauro sul punto di estinguersi, è un mammifero appena 
spuntato dallo stadio evolutivo precedente di pesce polmonato, un mollusco primitivo che per amore inventa la sua conchiglia. Qfwfq è tutto e niente, poiché è inafferrabile e indefinibile. È, possiamo dire, l'universo stesso nelle sue infinite metamorfosi sincroniche e diacroniche, l'intero che si mostra in frammenti di volta in volta diversi [is a nebula, is a simple aggregate of primordial matter, is a dinosaur about to go extinct, is a mammal just emerged from it previous evolutionary stage of pulmonate fish, a primitive mollusc which invents its shell because of love. Qfwfq is everything and nothing, because it is impossible to grasp and to define. It is, we can say, the universe itself in its infinite synchronic and diachronic metamorphoses, the whole showing itself in ever-changing fragments] (Iovino, "Quanto scommettiamo?" 114)

Within the NIE nebula, narration which takes unusual points of view is especially noticeable in Wu Ming's 54, in Roberto Saviano's "overloaded" point of view in Gomorra (see section 3.1.2), as well as in Giuseppe Genna's Grande madre rossa [Great red mother], which begins by describing Earth from a disembodied gaze floating ten thousand two hundred kilometres over Milan (Wu Ming, New Italian Epic 26, 30). In 54, Wu Ming describes Italy during the post-war economic boom from the point of view of a faulty (but conscious) television set. Italian literary writing has a strong tradition of exploring reality from unusual points of view. However, Wu Ming first explicitly theorises this oblique gaze, which exploits the capacity of the human mind for empathy, the process of identification of the self with another object. Such narratives encourage their readers to question the idea that the human point of view is the only possible one, or the only one worthy of consideration.

One reason why ecological problems have reached the current catastrophic proportions has been the perceived chasm between those who reap the benefits of the pollution and those who suffer its consequences: between human and nature, between the interests of the developed countries and those of the developing countries, between the current comforts that we enjoy and the 
hopes for a future prosperity. The creation of this chasm is primarily a failure in imagining that all separates us from the toxic habitat that we have created are but "porous borders" over whose inflows and outflows we have little control (Alaimo 156). We have little control over the toxins in the food we ingest, in the air we breathe, and in the water we drink. We have no control over the genetic material which moulds our bodies and which is 98 per cent identical with that of chimpanzees and 50 per cent identical with that of bananas. I have suggested the possibility that some literary writing could contribute to bridging this chasm between the self and the other. It is impossible to determine whether this enhanced awareness can be enough in itself to reverse the dangerous course that humanity has been following and to prevent the worst case scenarios elaborated in scientific model. Nonetheless, an increased awareness of the interconnectedness of all life is a prerequisite for understanding the damage that irresponsible lifestyles cause to the hopes of long-term prosperity for the human species and our non-human companions. At a time when desperate and dangerous measures such as geoengineering are being touted as lastresort actions to preserve the habitability of planet Earth, we cannot ignore the contribution that literary writing can offer to redefine humanity's environmental ethics.

\subsubsection{Moulding Moral Paradigms}

In the previous sections I discussed how literary writing provides a framework for mourning and a platform from which it is possible to explore the world through alternative points of view. I present now a third avenue through which narrative can contribute to improving the troublesome relationship between humanity and nature. Specifically, I argue that stories can shape a sense of morality in their readers. As well as an ecological problem, the degradation of the global ecosystem underlines some unquestioned assumptions that our current paradigm relies upon. The main issue that environmental philosophy identifies is whether our current anthropocentrism is justified or even beneficial 
to the long-term prosperity of humanity. Anthropocentrism is similar to frontier ethics (see section 1.2) in that it postulates the ultimate supremacy of humanity, asserting that its needs have to be considered exclusively. Anthropocentrism plays a comparable role within environmental philosophy as androcentrism plays in feminist studies and ethnocentrism plays in anti-racist theory ("Anthropocentric"; Plumwood 120).

Jèmeljan Hakemulder finds that "narratives can play a role in moral edification, a way of thinking rather than a way of judging" and that they can be used in moral development programs (158). Hakemulder also finds that there is unambiguous support "for the claim that narratives can be used as a basis for moral development programs" as long as discussions about the moral content of the stories follows the act of reading (56). In particular, narratives could be used in the classroom to enhance moral reasoning and to develop the prerequisites of ethical reflection in students (158). The development of moral and ethical reasoning through literature is a direct consequence of the development of empathy, self-knowledge, and self-discipline (166). This development directly contrasts consumerism, which encourages immediate sense gratification, substitutes self-enquiry with slogans, and depends on subsuming ethical considerations and empathy to the whims of the ego. As wells as contributing to developing empathy, reading stories also affects readers' self-knowledge and self-discipline. Experiments in text manipulation show that stories can significantly affect and clarify readers' self-concepts, and even modify beliefs that can in turn influence moral decisions. Hakemulder shows that exposure to a story about an adulterous couple "reduced male subjects' scores on adulterous selves" as well as caused "a significant effect on subjects' beliefs about the consequences of secret affairs" (129-140). Self-discipline is a factor which has been linked in children to increased happiness, capacity to cope with frustrations and stress, perseverance, concentration, self-esteem and overall more successful schooling (H. N. Mischel and W. Mischel; : Duckworth and Seligman). Evidence shows that time spent watching television appears to hinder attentional skills, stimulates hyperactivity, and increases impulsivity in 
children (Lemish 183). In contrast, engagement with texts forces readers to delay gratification, thus reinforcing self-discipline. In addition to the reinforcement, Hakemulder argues that catharsis (see section 2.4.2) could also have a role in the enhancement of self-esteem and self-discipline, especially within a social environment such as a classroom (160).

Hakemulder describes two main mechanisms through which narratives enhance ethical reflection and moral reasoning. First, there is evidence of a priming effect which makes norms and behaviours more readily available to mnemonic recall. This priming effect is triggered by reading about social transgression in narrative (79). Second, experiments have concluded that individuals learn new social behaviour from what they perceive as successful strategies. Evidence suggests that this mechanism applies to readers observing characters in narratives and that habitual readers will be familiar with a "wider gamut of behavioral situations" which helps them to define their moral and ethical stances in unexpected situations (83).

\section{In Practice: Parental Guidance}

In his essay "New Italian Epic: Noi dobbiamo essere i genitori" (2008), Wu Ming 1 quotes novelist David Foster Wallace who, in a 1993 interview, argues that whereas postmodernism was a liberating ritual, protracted carnivals become boring and revellers come to pine for order again:

The postmodern founders' patricidal work was great, but patricide produces orphans, and no amount of revelry can make up for the fact that writers my age have been literary orphans throughout our formative years. We're kind of wishing some parents would come back. And of course we're uneasy about the fact that we wish they'd come back - I mean, what's wrong with us? Are we total pussies? Is there something about authority and limits we actually need? And then the uneasiest feeling of all, as we start gradually to realize that parents in fact aren't ever coming back — which means we're going 
to have to be the parents (McCaffery 13 qtd. in Wu Ming 1,We're Going to Have to Be the Parents).

Wu Ming 1 argues that much of Western culture in the Eighties and Nineties lost the capacity to feel and react to danger and pain: as if we suffered from the medical condition of pain asymbolia, "we experienced or witnessed severe pain and reacted by giggling" (We're Going to Have to Be the Parents). One of the most evident symptoms of this social malaise is, as Bruno Latour points out, the denial industry's attempt to subvert postmodernist iconoclasm in a bid to "destroy hard-won evidence that could save our lives" (Latour 227).

We live at a time when nations seem unable to respond meaningfully to the destruction of the global ecosystem. Global warming denial appears as a reckless attempt to maintain the wasteful carnival that fossil fuels have made possible in spite of all warnings that science is sounding about the possible collapse of the global ecosystem and, with it, human civilisation. What if literary criticism could turn into a force capable of "generating more ideas than we have received, inheriting from a prestigious critical tradition but not letting it die away, or 'dropping into quiescence' like a piano no longer struck" (Latour 248)? I suggest that, indeed, the Humanities can contribute to the debate about the future of humanity and maybe show a path to enhanced resilience, harmony, and sustainability. Evidence shows that stories are able to influence behavioural patterns, thus, it is altogether possible that literary writing could offer moral and ethical guidance to a orphaned humanity which seems to have lost its capacity for feeling. If we liken literary writing to green technology, it becomes apparent that the technical means for a transition to a hopeful and prosperous future have already been developed and that the only resistance to their deployment lies in breaking the habits of old.

\subsection{Conclusion}

Human activities are gravely compromising the biosphere, greatly reducing biodiversity and jeopardising human civilisation itself. Narrative can offer 
an opportunity to review the relationship that determines human attitudes toward nature and can be used as a basis to encourage discussion about the relationship between humans and their environment and about sustainability. Communicators aspiring to elicit change in the habits of their public should attempt to frame their narratives in ways that are truthful, yet emotional. As journalist and environmental activist George Monbiot suggests, "we should embed both the awareness of these threats and their scientific description in a different framework; one that emphasises the joy and awe to be found in the marvels at risk; one that proposes a better world, rather than (if we work really hard for it), just a slightly-less-shitty-one-than-there-would-otherwisehave-been" ("An Ounce of Hope is Worth a Ton of Despair"). Literary writing clearly endows authors with the toolbox for arousing emotive responses in readers and I have outlined in this chapter some of the mechanisms that allow narrative to engender a positive change in attitudes to nature, promoting coherent and prudent, inclusive and just approaches to ecological problems. First, narrative introducing the topic of environmental degradation in a way that stimulates understanding, open-mindedness and self-enquiry offers guidance and encourages readers to respond positively to the tasks of mourning, and thus contributes to overcoming denial and powerlessness. Second, the practice of reading literary narrative which describes realities from unexpected points of view helps us to develop empathy, a psychological mechanism through which readers identify themselves with outgroups and improve their attitudes through an understanding of differences and similarities. Third, narrative has been shown to affect readers' morals and to contrast the harmful effects of consumerism on all counts: by encouraging self-discipline, by promoting and by guiding the development of deep and coherent thought which is necessary to understand the nature of the self, by developing empathy and understanding of the needs of others.

In the next chapters, I will discuss examples of contemporary Italian literary texts which depict radical ecological degradation. Through a close reading of these texts, I will highlight the mechanisms through which such stories enlighten 
and educate the reader, and thus contribute to imagining a human society which can flourish in harmony with the whole biosphere. 


\section{Chapter 3}

\section{Locality 1: Chemical Pollution}

The focus of this chapter is the representation of chemical pollution three works that respond to the characteristics laid out in chapter 2 Roberto Saviano's Gomorra: viaggio nell'impero economico e nel sogno di dominio della camorra (2006), Kai Zen's Delta blues (2010) and Wu Ming's Previsioni del tempo (2008). The first section of each analysis is dedicated to briefly introducing the work and justifying its inclusion within this thesis. To achieve this, I refer back to the four criteria enumerated in section 2.2 (environmental relevancy, year of publication, political intention) and explain how the text satisfies them. The second section ascertains which aspect of the complex phenomenon of chemical pollution the author focuses on.

Although Rockström's paper (see section 1.1) fails to quantify a planetary boundary for global chemical pollution, the devastating effects of the release of contaminants on local ecologies are apparent and well documented (473). But it would be a mistake to believe that environmental problems strictly pertain to the science of ecology and have no bearing on human beings. Although pollution refers to the uncontrolled release of toxic chemicals in the environment, modern biology shows that there is no impermeable barrier separating "us" from the threatening, toxic "outside". The idea of a permeable body lies at the core of material ecocriticism. In particular, Stacy Alaimo claims in Bodily Natures that "[h]umanism, capitalist individualism, transcendent religions, and 
utilitarian conceptions have labored to deny the rather biophysical, yet also commonsensical realization that we are permeable, emergent beings, reliant upon the others within and outside our porous borders" (156). Our "porous borders" disprove the convoluted sophisms that would see the (white and male) human as a transcendent organism at the top of the scala naturae, untouched by the filth of the material sphere. There is no way for humanity to insulate itself from the consequences of its actions because there is no way for the individual to insulate itself from the other. Paradoxically, as Carlo Lucarelli notes in the preface to Ecomafia 2013, the successes of the mafias, able to systemically permeate all facets of our existence, might have something to teach us about our cultural habit of fragmenting our society into separate, non-communicating entities (Osservatorio Ambiente e Legalità, Ecomafia 2013 7). The interaction between literary texts, toxic environments, human bodies, and criminal, often diseased minds exposes readers to the reality of the all-encompassing interconnectedness of nature-simultaneously its greatest vulnerability and its most valuable asset.

Another reason why ecology and society are inextricably conjoined is that the causes of pollution are invariably to be found in human society. Whereas ecology can accurately quantify and define environmental problems, and perhaps suggest paths to restoration, real long-lasting solutions have to be found in the restructuring of the relationship not only between human society and the biosphere, but among different human societies, and between human societies and the individuals which inhabit them. Several of the texts I analyse narrate the struggle and high personal costs that an individual has to bear to expose or oppose groups whose greed-driven actions are wreaking havoc on local ecologies. A postcolonial reading of this struggle allows us to see ecological woes as hostile actions by a colonising outgroup pursuing economical and social dominance at the expense of what they contemptuously perceive to be disposable indigenous communities. In fact, it is possible to apply Nixon's framework of "slow violence" so as to document the deleterious (though often invisible) effects of the economic and industrial activities depicted in the texts. 
The section "Narrative Focus" highlights a few themes that recur in most of the texts discussed and investigates how each author deals with them, but it is neither meant to imply that all of the texts focus primarily on the issues that are referred there nor that other issues are absent from them. Its aim is to help navigating the texts by pointing out recurring themes.

\section{Environmental Discrimination}

It is common for dominant social groups not only to relegate disadvantaged communities to less desirable locations, but also to utilise such places as receptacles for toxic industry by-products. The term "environmental racism" first came to public attention in 1982 during the protests against the siting of a hazardous waste landfill in Warren County, North Carolina (Holifield 83). One of the protest leaders, Benjamin Chavis, produced the first definition of the phrase:

Environmental racism is racial discrimination in environmental policy-making and enforcement of regulations and laws, the deliberate targeting of communities of color for toxic waste facilities, the official sanctioning of the presence of life threatening poisons and pollutants for communities of color, and the history of excluding people of color from leadership of the environmental movement (Bullard xii).

A proper definition of environmental racism is still subject to discussion within the legal and academic communities, with scholars debating the relevancy of citing "deliberate" discriminatory intention (Holifield 83). Environmental racism does not necessarily follow so-called racial boundaries, but instead has very straightforward economic reasons. In 1991, a memo from Professor Lawrence H. Summers, then vice president of the World Bank, was leaked to the press. The memo illustrates the case in point and shows the rationalisation of practice of dumping toxic pollution in less developed countries. In his memo, Prof. Summers claims that "the economic logic behind dumping a load of toxic waste in the lowest wage country is impeccable", laments that trade in pollution 
towards the less developed countries is hampered by the fact that "the unit transport costs of solid waste are so high", and finally argues that "[ $t]$ he concern over an agent that causes a one in a million change in the odds of prostrate [sic] cancer is obviously going to be much higher in a country where people survive to get prostrate [sic] cancer than in a country where under 5 mortality is 200 per thousand" (Engwegbara 7). Summers has since retracted and claimed that the memo was to be meant as "sarcastic", but it matters little ("Furor on Memo At World Bank"). Poe's Law aptly explains that, "without a ... blatant display of humor, it is uttrerly [sic] impossible to [create a parody of extremism or fundamentalism] that someone won't mistake for the genuine article" (Poe). we can never know whether Summers originally intended his memo seriously or not.

Apart from the astounding level of cynicism displayed by employees of an institution whose stated goal is to "reduce poverty and support development", the Summers' memo shows that environmental racism is a misnomer and should be renamed environmental discrimination. In fact, whereas racism depends on ideology, discrimination derives from socio-economic considerations in addition to the perceived distance between those who take decisions and those who need to suffer them than (The World Bank). My textual analysis repeatedly highlights how damaged environments are often a product of short-sighted, cynical and often criminal economic policies as well as of the contempt in which powerful individuals and organisations hold the people they exploit.

\section{Toxic Business}

In the last 20 years, Italian-based organised crime has become stronger and richer than ever. There are understandable problems in trying to calculate the profits of organised crime. Thinktank Transcrime estimates that their annual revenues lie between 8.3 and 13 billion euros ("Mafia investments"). By contrast, the antiracket organisation "SOS Impresa" provides a much higher figure of a hundred billion euros of yearly profits for the mafias ("Sos Impresa: 'Mafia Spa è la prima banca d'Italia'"'). But no matter which is correct, organised 
crime represents a sizeable fraction of the Italian economy, with billionaire interests that reach most continents. Mafias only started to internationalise during the first half of the twentieth century, first through mass-migration of Sicilians fleeing to the United States from poverty and then from Mussolini's heavy-handed repression of the Mafia in the late nineteen-twenties (see Lupo 209-225). Since then, gangs have dramatically expanded their operations by creating new markets for conventional criminal activities such as drugs, weapons, and prostitution but also, more recently, by opening new unexpected streams of revenue. One of the most lucrative of these is the illegal dumping of dangerous waste in unprotected sites. The term I will use to refer to the practice of deliberately releasing toxins in the environment for purposes of financial gain will be "ecomafia". Legambiente first introduced the term in 1994, when it published its first Rapporto Ecomafia. However, the word officially entered the Italian language only in 1999, when it was included in the authoritative Treccani dictionary. The online version of the Treccani dictionary lists ecomafia as “[s]ettore della criminalità organizzata che gestisce attività illecite di dannoso impatto ambientale (smaltimento dei rifiuti tossici, costruzione di insediamenti industriali e abitativi abusivi, inquinamento delle falde acquifere per effetto di sostanze industriali di scarto, ecc.)" [branch of the organised crime which manages illegal activities causing environmental damage (disposal of toxic waste, illegal building of industrial and residential sites, contamination of groundwater due to industrial waste materials, etc.)] ("Ecomafia").

"La monnezza è oro" [Rubbish is gold], said captive pentito boss Nunzio Perrella to attorney Franco Roberti in 1992 (Marino). And indeed it is. In the preface to Rapporto Ecomafia 2012, Roberto Saviano writes, "1'economia mafiosa è in attivo ... Nel 2011 il guadagno degli ecomafiosi è stato di 16,6 miliardi di euro. Dal 1992 hanno fatturato 300 miliardi di euro" [the economy of the Mafia is fluorishing ... In 2011 the profit of the ecomafiosi amounted to 16.6 billion euros. Since 1992 they have earned 300 billion euros] (Osservatorio Ambiente e Legalità, 


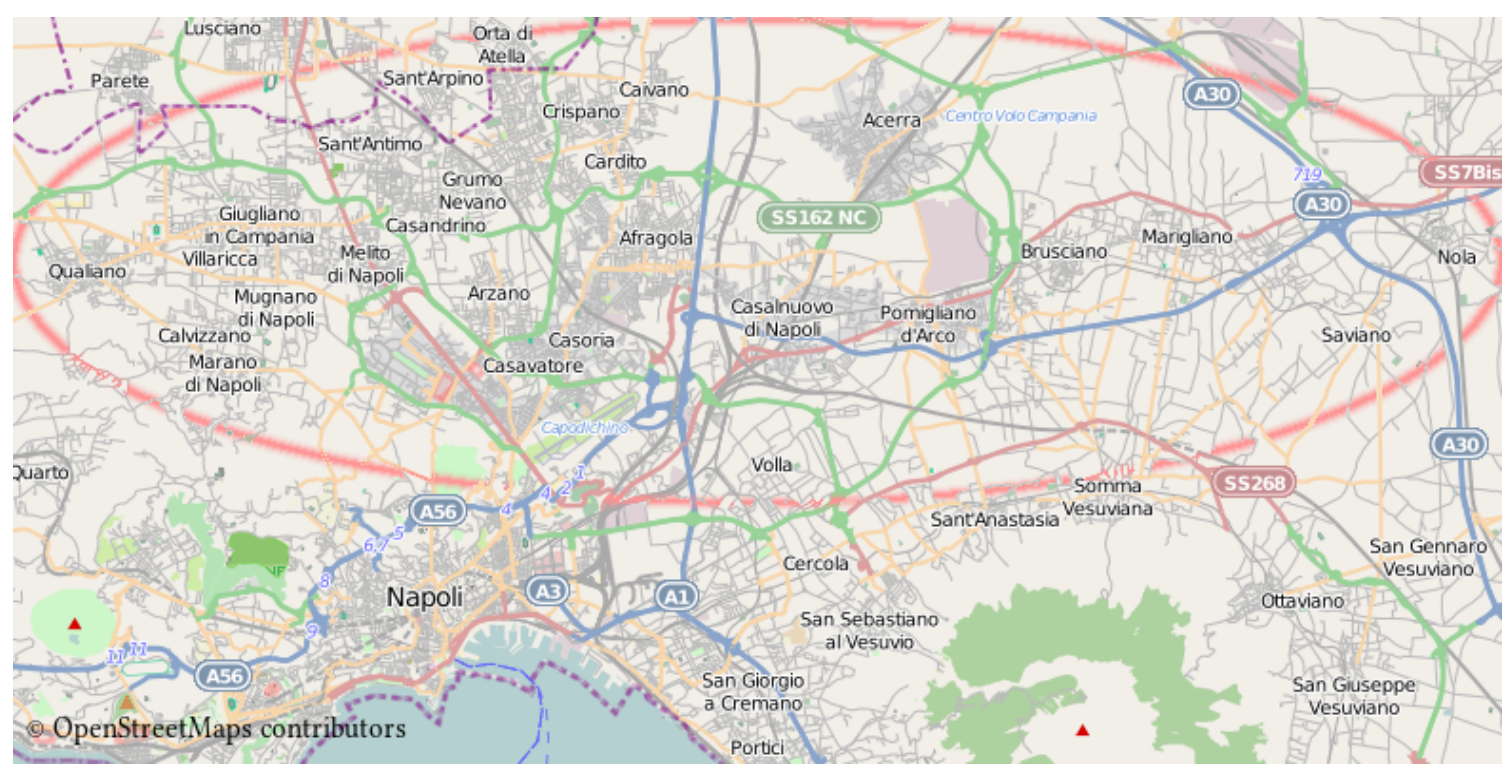

Figure 3.1: The Land of Fires

Ecomafia 2012 8) [1 Ecomafia is already causing incalculable damage to the economy, not to mention immense suffering, disease, and death to ecosystems and populations. The phenomenon of ecomafia is currently a profitable, low-risk, and therefore widespread business - especially in Southern Italy, and especially in the countryside spanning the Neapolitan municipalities of Nola, Marigliano, and Acerra, an area which has been dubbed "il Triangolo della Morte" [the Triangle of Death] or "la Terra dei Fuochi" [the Land of Fires] (see figure 3.1) because of the high incidence of cancer linked to environmental pollution (Senior and Mazza 2,3). The texts I discuss all focus primarily on unravelling the logics of ecomafia, and all of them expose situations where international organisations deliberately flout environmental laws and regulations (not to mention basic ethical principles) in an attempt to maximise private profit at the expense of the indigenous populations and their territory.

${ }^{1}$ Note that the figure that Saviano produces refers to the whole range of ecomafia activities, of which the management of special waste and unauthorised building (chapter 4 ) are the most profitable, but that includes trade in protected species, trade in archaeological artefacts, and illegal activities within the food industries (Osservatorio Ambiente e Legalità, Ecomafia 2012 68). 


\section{Diseased Places, Diseased Minds}

Degraded environments not only threaten physical health: humanity had its cradle in forests and savannahs, and most individuals feel most at ease when they have access to green spaces. Literary texts also build a link between diseased places and diseased minds and, though unable to provide evidence, offer yet another vantage point from which readers can independently explore the "porous borders" between the psyche and the environment.

As mentioned before, in her Bodily Natures, Stacy Alaimo writes that there are no impermeable barriers separating the body from the outside. In the same way, she argues that also the mind/body dualism has also been "cultivated to denigrate certain groups of humans as well as nonhuman life" (5). The rejection of this instance of "frontier ethics" is the foundational principle of material ecocriticism. Therefore, because all that separates the environment and the body are "porous borders" and because the mind is an emergent property of the body, it is very likely that diseased places will produce diseased minds. Also, because the mind dictates the individual's behaviour in his or her environment, diseased minds will engineer diseased places in their own image.

There is a growing body of scientific literature which confirms the reciprocal relationship between mind, body, and environment. Research in the social sciences links well-being with access to green spaces. In his book Last Child in the Woods: Saving Our Children from Nature-Deficit Disorder, Richard Louv establishes a causal link between better school performance, stronger confidence, and lower risk of developing mental diseases in children and the enjoyment of an unmediated contact with nature $(229,44,207)$. In their review of the scientific literature, Cecily Maller et al. find that theoretical, empirical, and anecdotal evidence overwhelmingly supports the view that contact with nature benefits individuals both physiologically and psychologically including quicker "recovery from mental fatigue", a higher number of "healing patients who previously had not responded to treatment", "a more positive outlook on life and higher life satisfaction", and an increased "ability to cope with and recover from stress" (50). 
But what about diseased minds engineering diseased places? Psychologists have so far failed to provide a straightforward definition of psychopathy, but they have produced lists of traits which make it possible to recognise psychopathy, such as the "Hare Psychopathy Checklist". Traits associated to psychopathy include manipulativeness, remorselessness, callousness, irresponsibility, poor behavioural control, juvenile delinquency, and criminal versatility (Skeem et al. 101). Although psychopathy is not synonymous with crime and some individuals showing psychopathic traits become successful politicians and business leaders, many pick up criminal roles as a result of their lack of empathy and ruthlessness (103). Criminal behaviour in turn creates unfavourable conditions for non-psychopaths to thrive, including rising violence and lawlessness, pollution, lack of trust in others and in institutions, lack of security, and loss of life. Virtually all of the literary authors discussed in this chapter make explicit the relationship between psychopathy and environment in their texts and illustrate how power-thirsty and ethically deficient characters aggressively pursue their goals with no concern for the consequences they are inflicting on the community and on the environment because they place no value on those assets.

In my analysis, I use the theories introduced in section 2.4. Can literary texts only ever hope to inform and entertain their readers or are there strategies through which they might affect readers' behaviour, and ultimately change society? As argued in section 2.4 , there is no clear answer. However, it is certainly possible to identify the strategies that authors employ in their narration when they wish to engage with their readers' worldview and to promote specific ideas.

\subsection{A Toxic Tour through "La terra dei fuochi"}

Roberto Saviano's bestseller Gomorra (2006) endeavours to expose and explain various aspects of the economy of the infamous Neapolitan mafia, the Camorra. This analysis focuses especially on the book's final chapter, "La terra dei fuochi", 
because it is a powerful, convincing depiction of the Camorra's environmental crimes: their magnitude, their mechanics, and their effects. With the publication of his book, Roberto Saviano broke omertà-rule number one of peaceful coexistence with Italian organised crime. As a consequence, he is paying for his literary success with death threats from the Camorra, forced to live under police escort. Saviano explains the reasons that convinced him to publish his book although he knew that doing so would jeopardise his life. In order to find clarity on what he knew about the Camorra, he went to visit Pier Paolo Pasolini's tomb in Casarsa in order to "riflettere senza vergogna sulla possibilità della parola" [to reflect without shame on the possibility of the word] (Saviano 233).2 The faith in the power of words that moves Gomorra is founded on the belief that, as Wu Ming argues, art and literature cannot just sound belated alarms but must strengthen our imaginative skills and help us imagine ways out (Wu Ming, New Italian Epic 60). By broadening our horizons and creating alternative realities, literature may help us re-imagine what progress means. This faith in the maieutic and healing powers of words is the same that animated Pier Paolo Pasolini, but in Roberto Saviano it becomes more mature and dangerous. In 1974, Pasolini wrote in his "Io so" article: "Io so. Ma non ho le prove. Non ho nemmeno indizi" [I know. But I do not have evidence. I don't even have clues.] ("Io so]"). In contrast, Saviano repeats "Io so e ho le prove" [I know and I can prove it] (234-240).

However, he continued, his knowledge was deeply personal: the proofs he presented "sono inconfutabili perché parziali, riprese con le iridi, raccontate con le parole e temprate con le emozioni rimbalzate su ferri e legni" [are irrefutable because they are partial, recorded with my eyes, recounted with words, and tempered with emotions that have echoed off iron and wood] (Saviano 234). In Gomorra's apocalyptic scenario, a mere impulse to know sounds like a blandly hopeless intellectual attempt to escape the harshness of reality. Gomorra aims at probing deeper truths-truths that are inextricably linked with the fabric of reality. Thus, for Saviano, exposing the ideology and the business of the

\footnotetext{
${ }^{2}$ Gomorra translations by Virginia Jewiss from Gomorrah: Italy's Other Mafia.
} 
clans with the power of literature becomes more important than threats to his life. Because of this, Gomorra becomes a political act aimed at denouncing the Camorra's stranglehold on Naples, Italy and the world.

\subsubsection{The Mechanisms of Gomorra}

The dreadful Land of Fires is a toxic wasteland in the middle of what used to be a rich agricultural area in Italy, known in Roman times as Campania felix-the fertile countryside. No more. Saviano's Gomorra superimposes onto the image of green pastures and bucolic views from the past a much more disturbing, and alas, accurate one. In fact, rampant crime has for decades been using this territory as a repository for all kinds of toxins, thus irreparably compromising it, as Esmeralda Calabria and Andrea D'Ambrosio show in their film Biùtiful cauntri (2008) and Ivana Corsale in her Campania In-felix (2011). Although, similarly to Gomorra, these two documentaries vividly denounce the slow violence that the Camorra perpetrates against the inhabitants of the Land of Fires, Saviano's text predates and probably inspires both of those titles, which means that the public had already been familiarised with this great devastation by the time the two films were first released. At the same time, Gomorra relays its message through the medium of written word rather than through film. Finally, whereas Corsale and Calabria and D'Ambrosio present their works as "non-fiction documentaries", as we have seen, Gomorra is not so easily categorised-so much so that it has been defined an "Unidentified Narrative Object": Saviano lets his readers decide for themselves whether to read Gomorra as fiction or as a truthful account-although the recent declassification of ex-boss Carmine Schiavone's confession leaves little room for skepticism (Wu Ming 1, "Premessa alla versione 2.0 di New Italian Epic" 8).

But even though Gomorra does not cite any sources, much of what Saviano writes will sound familiar to those who are acquainted with Legambiente's Rapporto Ecomafia. Since 2006, many names have changed: the career of the mafioso is often brief, ending in incarceration or death, and new politicians 
have succeeded the old ones. However, the mechanisms that enable the clans to prosper and profit are the same, and deadly chemical cocktails still corrupt the land and the people. Gomorra's stakeholders are still at work: they are " $\mathrm{i}$ colletti bianchi dell'ecomafia, quelli che avvelenano e uccidono con la penna" [ecomafia's white collars, those who poison and kill with the pen] (Osservatorio Ambiente e Legalità, Ecomafia 2013 122). The effects of toxins on Campania's agriculture were as destructive in 2013 as they were in 2006: "[i]nsalate al cadmio, finocchi da sballo, broccoli fumé, zucchine impazzite, pomodori alla diossina, frutta al percolato e pesche miracolate" [cadmium salads, buzz fennels, smoked broccoli, crazy zucchini, dioxin tomatoes, leachate fruit and miracle peaches] (126). In 2013, people were still dying of ecomafia as they did in 2006: cancer death rates have increased in the last 20 years by 47 percent for men and 40 percent for women in the countryside surrounding Naples compared to stable national rates (135). Thus, although Saviano's Gomorra cannot be made to fit squarely into any literary genre, and although there is no way for the reader to ascertain the literal truth of many episodes, evidence shows that the phenomenon that Saviano reports indeed exists in the terms that he lays out.

Gomorra describes the anarcho-capitalist ideology the Camorra and part of the Italian entrepreneurial class share. As the mind of the Camorra affiliates is polluted with psychopathic greed, it turns its once-fertile landscape into a barren, toxic wasteland. This callous behaviour once again reveals a selective vision where greed is taken as a teleology and everything disregarded outside of the immediate economic interest, but it is obvious that such reductionism has huge costs for society.

In Gomorra, Roberto Saviano invites the reader to "follow the money" to understand why waste accumulates in the four regions where unemployment and organised crime are most widespread, suggesting that the extreme degradation of the Neapolitan countryside can be ascribed to both poverty and the cynical logic of unrestrained capitalism that organised crime pursues. Whereas the mindset of illegality and greed that dominates Southern Italy encourages organised crime to abuse the territory, short termism and a culture 
which devalues the territory have created the apocalyptic scenario of the Land of Fires. Writing about Gomorra in the journal Carmilla Online, Valerio Evangelisti notes that in Gomorra, "la criminalità non è un elemento sussidiario del capitalismo, una sua perversione. Al contrario, ne rappresenta il cuore, un pilastro strutturale" [crime is not an ancillary element of capitalism, its perversion. On the contrary, it is its heart, a structural column] ("Literary Opera. Evangelisti e Lucarelli sul New Italian Epic')' Bearing in mind this observation, I will now briefly address the causes that have conspired to enact the continued apocalypse of the Land of Fires.

Institutions measure economic growth through the use of economic measurements such as Gross Domestic Product (GDP), but Saviano proposes a more tangible unit to measure of industrial activity: waste. How so? On the one hand, the natural world follows a circular paradigm which endlessly recycles nutrients and materials within the biosphere. In the nutrient cycle there is no place for waste intended as material that no other living being can use: one creature's waste is, without exception, another's food. On the other hand, the current industrial economic paradigm relies on a linear approach of take-makedispose: first, raw materials are harvested from mines, forests, oceans; then products are manufactured and sold; finally, having reached the end of their perceived usefulness, they are disposed of. But whereas the circular approach has worked for as long as life has populated the Earth, a linear approach is unsustainable in at least two ways on a planet where both resources and space are finite. First, raw materials are harvested without any considerations for the long term, they inevitably deplete; and second, as finished products are disposed of in the most cost-effective way, they tend to accumulate and often release toxic substances-as Italo Calvino's Leonia in Le città invisibili shows.

The hand of the unregulated market may be invisible but it is not indiscriminate. Extraction necessarily happens where the resources are, manufacture develops where the workforce is cheapest. But what are the parameters that determine disposal of often dangerous waste? "Lo smaltimento è un costo che nessun imprenditore italiano sente necessario" [Waste removal is 
an expense that no Italian businessman feels necessary], and therefore lacking an external regulatory framework, no entrepreneur will voluntarily choose a more expensive yet safer disposal option, choosing instead the most cost-effective option. (Saviano 318). But cost-effectiveness means that waste, by definition considered a liability in the linear paradigm, often ends up where the regulatory framework is weaker, where corruption is most widespread, and where the population fails to identify itself with (and hence protect) the territory it inhabits. In the case of Italy, "La parte più consistente dei traffici di rifiuti tossici ha un vettore unico: nord-sud" [Most trafficking in toxic waste runs in just one direction: north to south] (312). And in fact, Osservatorio Ambiente e Legalità's Rapporto Ecomafia shows that most environmental crimes in Italy consistently happen in four regions: Campania, Sicily, Calabria and Apulia (Ecomafia 2010; Ecomafia 2011; Ecomafia 2012; Ecomafia 2013). As Saviano suggests, the mountains of waste are a metaphor of our unsustainable economic linear paradigm which produces wealth at its centre but inevitably degrades its periphery with toxins and destruction. But while it is true that the environmental crisis of the Land of Fires is in part imputable to the reckless capitalist logic of the clans, this cannot be the only reason for this continued apocalypse.

In fact, most camorristi hail from and in fact still live in some of the most polluted areas around Naples, and thus one may ask what has motivated them to turn the Neapolitan countryside into a wasteland. The 1997 confessions of Camorra pentito Carmine Schiavone reveal that the clans have been fully aware that burying waste (including radiactive waste) would terminally pollute the lands they lived on and slowly kill their inhabitants (Scalia 1, 7, 12). Does greed alone justify terminally polluting your own homelands as the Camorra has done? Saviano believes there are ulterior causes to this recklessness: "[i]ngolfare di rifiuti tossici un territorio, circoscrivere i propri paesi di catene montuose di veleni può risultare un problema solo per chi possiede una dimensione di potere a lungo termine e con responsabilità sociale" [[t]o flood an area with toxic waste and circle one's city with poisonous mountain ranges is a problem only for someone with a sense of social responsibility and a long-term concept of power] 
(312). The camorristi, hounded by police and competing clans, knowing that they will not be able to cling to power and riches for long, suffer from a restricted event horizon, which leads them to consider only the possibility of immediate gain and to discount the long-term damage they inflict on their own homelands. Although it is apparent that the Camorra's anarcho-capitalism is short-sighted, time constricts the bosses' power: they know that, inevitably, they will soon be arrested or killed and the consequence of such awareness is the application of a very high discount rate to every transaction because "nel tempo immediato dell'affare c'è solo il margine di profitto elevato e nessuna controindicazione" [[i]n the here and now of business, there are no negatives, only a high profit margin] (312).

Here, again, Saviano draws a parallel between lawful capitalist practices on the one hand, and organised crime on the other, showing that short-sighted pursuit of profit is incompatible with a responsible stewardship of the land and is not exclusive to the Camorra. Those who work, live, and profit in the Camorra's shadow are legion because the mechanisms that enable the Camorra to outcompete its legal competitors are deeply ingrained in the culture of individualism and mistrust of society. Perhaps the episode that best illutrates this fact to the reader is the stakeholder's reaction to Saviano's ethical qualms: "Ti fa schifo questo mestiere? Robbe', ma lo sai che gli stakeholder hanno fatto andare in Europa questo paese di merda? Lo sai o no? Ma lo sai quanti operai hanno avuto il culo salvato dal fatto che io non facevo spendere un cazzo alle loro aziende?" [Does this job disgust you? Robbe', do you know that the stakeholders are the ones who made it possible for this shit country to enter the European Union? Yes or no? Do you know how many workers' asses have been saved because I fixed it so their companies didn't spend a fucking cent?] (321-322). The stakeholder correctly points out the savings that he can offer to his clients, but fails to account for the externalities, that is, the cost that society will have to bear in terms of disease and loss of agricultural productivity. The poisonous mix of wilful ignorance, distrust for society and disregard for the law, extreme individualism and unfair business competition, 
not to mention the utmost contempt Camorra gangsters harbor towards their own townfolk seeps into the environment in the form of industrial pollutants and undermines the health of landscape, agriculture and people. Because of this, it is no wonder that "[1]'agricoltura di questi luoghi, che esportava verdure e frutta fino in Scandinavia, crolla a picco. I frutti spuntano malati, le terre divengono infertili" [[t]he local agriculture, which used to export fruit and vegetables as far as Scandinavia, is collapsing. Plants sprout diseased, and the land grows infertile] and that "la mortalità per cancro in Campania, nelle città dei grandi smaltimenti di rifiuti tossici, è aumentata negli ultimi anni del 21 per cento" [cancer mortality rate in Campania cities with substantial toxic waste sites has increased by 21 percent in recent years] (326-327). In fact, we could rephrase the above question about the Camorra in global terms: does the pursuit of profit legitimise degrading the global ecosystem to the point that it fails to provide for its (future) inhabitants? Stewardship of the land requires vision and longterm planning, which are incompatible with the "get rich quick" mentality of organised crime and assault capitalism.

\section{Civil Disobedience and Awakening}

But of course the Camorra is not the only actor in Campania and in the South: their population and institutions also play a role in the drama of waste. As Iovino notes, however, the role of the population is, for historical reasons, one of passive resignation, which harks back to long before Italy's Unification. Naples' history is one of foreign dominations, succession wars, changes of regime and failed revolutions, which have contributed to keeping the population in a permanent state of poverty and illiteracy, resentful and suspicious of a state which they feel as oppressive and illegitimate. Iovino attributes the Naples waste emergency to a sense of powerlessness on the part of the citizens, to the fact that "political and economic powers, and secondly criminal powers made the population 'alien' to itself and also to its social role" ("Naples 2008, or, the Waste Land" 5). Just like the camorristi, the general Neapolitan population suffers from a sense of detachment from the land which feeds and sustains it, and 
the business of waste only fuels this vicious circle: the more the land becomes degraded, the more farmers abandon it, the lower the price the Camorra pays to dump poison (Saviano 326).

Iovino writes that it is not possible to frame the Neapolitan waste management crisis in the terms of "environmental racism" but as "an exclusion from political decision making. Firstly, political and economic powers, and secondly criminal powers made the population 'alien' to itself and also to its social role" ("Naples 2008, or, the Waste Land" 7). History shows that an empowered population strenuously resists attempts to abuse its territory. A striking example of civil disobedience (though tainted with NIMBYism) has to be found in the "No-TAV" movement, whose activists have been preventing since 1995 the development of the Turin-Lyon high-speed railway in the Val di Susa valley in Piedmont. On the other hand, the Camorra continues businessas-usual in Naples, where citizens have been disempowered and alienated by a long history of local mismanagement, corruption, and collusion of the political elite with criminal powers.

From these premises, it is possible to understand why the stakeholders favour the Neapolitan countryside as a repository for the North's wastes. Economy chooses the path of least resistance and a watchful population can but increase risk and costs of unlawful enterprises; however, this resistance is almost non-existent in and around Naples, where an acquiescent and alienated population, educated to omertà and resigned to passivity offers a perfect environment for the Camorra to conduct its dirty business undisturbed. In light of these arguments, Iovino's observation that it is not possible to talk about "environmental racism" in Naples chimes in with my argument that in Italy the causes of environmental discrimination are cultural and economic rather than racial or ideological. Furthermore, Iovino's social critique of the 2008 Naples waste emergency explains why repression is insufficient to address the problem of Camorra. Changing a culture requires indeed a herculean and sustained effort, and entrenched powers will resist the change; nonetheless it is possible. To create a culture less favourable to the Camorra, Iovino suggests it is necessary to 
"restore social hope, to become 'prophetic"' and to "replace NIMBY-attitudes ... with civil disobedience" through an ecological culture that "has to be a culture of citizenship and of empowerment, protecting and preserving the territory, instead of making it a waste land". At the individual level, this paradigm shift is made possible through awareness of mortality which becomes awareness of meaning. Citing Heidegger, Iovino argues that

only when the human, from dejection (and as such waste, outcast) becomes aware and master of its own end, does it attain a sense of self. If I am aware that my being will cease, I am. If I recognize myself as subject to decay, 'disposable,' 'surpassable,' 'discardable,' I stop to be ab-jectum (waste; outcast; trash), and I become pro-jectum, namely, aware of the sense of my being in the world ("Naples 2008, or, the Waste Land"' 8).

Roberto Saviano as character goes through a similar epiphany at the conclusion of Gomorra when, while clinging for life to a discarded fridge in a flood that threatens to drown him, he realises that, despite everything, he is still alive:

Avevo i piedi immersi nel pantano. L'acqua era salita sino alle cosce. Sentivo i talloni sprofondare. Davanti ai miei occhi galleggiava un enorme frigo. Mi ci lanciai sopra, lo avvinghiai stringendolo forte con le braccia e lasciandomi trasportare ... Avevo voglia di urlare, volevo gridare, volevo stracciarmi i polmoni, come Papillon, con tutta la forza dello stomaco, spaccandomi la trachea, con tutta la voce che la gola poteva ancora pompare: «Maledetti bastardi, sono ancora vivo!» [My feet were deep in the mire. The water had risen to my thighs. I could feel my heels sinking. A huge refrigerator floated in front of me. I threw myself on it, clutching it tightly with my arms, and let myself be carried ... I wanted to shout, to scream, to tear my lungs out like Papillon. I wanted to howl from deep down in my gut, my throat exploding with all the voice left in me: "Hey, you bastards, I'm still here!"] (331). 
This piercing scream condenses Gomorra's raison-d'être: a powerful denunciation of the Camorra that at the same time shows the path for the healing of the individual and society.

\subsubsection{Saviano's Narrative Strategies}

In their 2008 essay “New Italian Epic 3.0: Memorandum 1993-2008”, Wu Ming proposes to create a kind of "nebula" where congenial literary works clump together and names it "New Italian Epic" (Wu Ming, New Italian Epic 11). Wu Ming explains that in this context, "epic" means "imprese storiche o mitiche, eroiche o comunque avventurose" [mythical or historical deeds, heroic or adventurous in any case] (14). Epic stories, according to the Treccani dictionary, narrate "gesta eroiche, spesso leggendarie" [heroic, often legendary deeds] ("Epica"). These stories are hard to believe because of their vastness and their distance from the reader's experience. Because of the outlandishness it describes, "epic" is semantically associated with "unbelievable", "unimaginable". In his essay "Sentimento Nuevo", Wu Ming links "epica" with both hyperbole and the Freudian idea of unheimliche: the uncanny, the intangible feeling of anxiety we feel when the dreadful "primitive" emerges within the familiar "modern" (Freud xlix). Conversely, the hyperbolic element of NIE comes from the fact that in these texts, "ogni elemento è più denso, più carico, più vivido, eppure al tempo stesso più sfuggente, difficile da definire e contornare" [each element is denser, more loaded, more vivid, but at the same time more elusive, harder to define and outline]. Given that $\mathrm{Wu}$ Ming summarises this concept with the formula:

$$
\text { Magnitude }+ \text { Uncanniness }=\text { Epic }
$$

it is easy to see why Gomorra lies at the core of the "New Italian Epic" nebula (New Italian Epic 72). But because Saviano's Gomorra presents itself as "truth", a "willing suspension of disbelief" is not justified, skepticism is warranted and the text needs to earn its public's trust, a mission that apparently contrasts with the work's uncanniness and its magnitude-in one word, with its being epic. Only through making the public's trust in Gomorra's message stronger than its 
magnitude and uncanniness, will its author be able both to convince and move his readers.

Thus, it is true that Saviano names names, sources, numbers and chemistry, and the bizarre logic of the police report codes. It is also true that Carmine Schiavone's recently declassified 1997 confessions have to all effects corroborated Saviano's account of rubbish turning into gold. The police operation "Madre Terra" discovered that printer toners were being disposed of by burying them, thus contaminating agricultural lands with carcinogenic hexavalent chromium (315). The "Operazione Houdini" found out that 200 thousand tonnes of waste per year "disappeared" in a single processing plant (319); and the "Re Mida" enquiry was thus named because Camorra gang members were, like the legendary king, able to turn waste into gold (321). Saviano exposes his readers to deadly number-crunching when he publishes the stakeholder's price lists to dispose of dangerous materials: "diluenti ... dai dieci ai trenta centesimi al chilo. Pentasolfuro di fosforo un euro al chilo. Terre di spazzamento delle strade, conquantacinque centesimi al chilo; imballaggi con residui di rifiuti pericolosi, un euro e quaranta centesimi al chilo; fino a due euro e trenta centesimi al chilo le terre contaminate" [thinners ... go from 10 to 30 eurocents a kilo. Phosphorus sulfide is 1 euro a kilo. Street sweepings 55 cents; packaging with traces of hazardous substances, 1.40 euros; contaminated soil up to 2.30 euros] (319). However, numbers are useless if not paired with names that qualify them, which turn them from abstract quantities to concrete entities, and into accusations. Since business requires two parties, Saviano (staying true to the animus narrandi of Pasolini's "Io so") names the family names of notorious clans involved in the business (which earned him death threats and a police escort) as well as the industrial entities benefiting from their services such as the "ex Enichem di Priolo, i fanghi conciari della zona di Santa Croce dell'Arno, i fanghi dei depuratori di Venezia e di Forlì di proprietà di società a prevalente capitale pubblico" [old Enichem of Priolo; sludge from tanning factories near Santa Croce sull'Arno; and sediment from the purifiers of primarily publicly owned companies in Venice and Forlí] (316). By providing data and facts his readers can 
relate to and have probably heard while watching the news, Saviano builds a narrative which connects the dots and reveals the true magnitude of Gomorra's culture of criminality, unveiling the support it draws from industry. Whereas the police investigating environmental crimes or discovering illegal dumps is a commonly heard theme in Italian news reports, the proportion of the whole problem defies the public's imagination until the author's narrative skills collect and expound them in a single location.

While quantifying, visualising and imagining are necessary steps in awakening a response in the readership, they are not sufficient. The information deficit model shows that merely presenting reliable evidence and data is an inefficient way to have the public face difficult, or unpleasant realities and that many will fall into denial rather than accepting inconvenient information (see section 1.2). Next, I will illustrate how Saviano manages to overcome these

obstacles by presenting information in a way that enables his readers to acquire a sense of trust in the narrator.

\section{Polluted Materiality}

We have seen how Roberto Saviano reinterprets Pasolini's "Io so" at the writer and director's tomb in Casarsa, and realises that words have to transubstantiate. Just as the Catholic priest transubstantiates bread and wine into the blood and flesh of Christ during the Eucharist, the writer needs to turn words into blood and flesh-but also soil, water and trash-in order to significantly affect the readers' bodies. It is through this literary Eucharist that Saviano provides the means to help the reader imagine the drama which is unfolding in the Neapolitan countryside, and his strategy pays off. He begins his tale of dangerous waste with an invitation to try and imagine the unimaginable:

la cosa più complicata è immaginare l'economia in tutte le sue parti ... Se si prova a immaginarla, l'economia, si rischia di tenere gli occhi chiusi per concentrarsi e spremersi sino a vedere quelle psichedeliche deformazioni colorate sullo schermo della palpebra [[i]t's far more 
difficult to imagine the economy in all its aspects ... If you try to imagine it all, you risk shutting your eyes to concentrate and racking your brains till you start seeing those psychedelic distortions painted on the backs of your eyelids] (Saviano 310).

In order to overcome this barrier, it is necessary to anchor such abstractness to the physical, inevitable end-product of all economic activity-waste. Similarly, reading Gomorra, and in particular the chapter "La terra dei fuochi", it is possible to detect how Saviano adopts very material metaphors to forcefully evoke abstract concepts within the reader's imagination. Saviano compares the economy to a snake, its shed skin the trail of waste it leaves behind as it proceeds: "l'unico modo per rappresentare l'economia nella sua corsa era intuire ciò che lasciava, inseguirne gli strascichi, le parti che come scaglie di pelle morta lasciava cadere mentre macinava il suo percorso". Turning abstraction into the material reality of the Land of Fires unmasks the economy's "operazioni commerciali, le sottrazioni e le somme dei commercialisti, i dividendi dei profitti" [commercial transactions and profit dividends, the addictions and the subtractions of accountants] and reveals its true physical nature, that of a monstrous mountain of waste spread throughout Southern Italy (Saviano 311).

The amount of waste that has been illegally dumped in the Land of Fires is inconceivable and thus Saviano must qualify his statements by adopting the same metaphorical language that astrophysicists use to describe unfathomable sidereal distances, comparing the abstract to the concrete, gauging the unfamiliar through the familiar. The amount of rubbish that the black market manages has been estimated at an astronomical "quattordici milioni di tonnellate: praticamente come una montagna di 14.600 metri con una base di tre ettari" [14 million tons and rising 47,900 feet from a base of three hectares] (Saviano 283). Also unimaginable is the equivalent of 28,000 trucks full of waste dumped in a single abandoned quarry. However, he writes, the quantity can be visualised by imagining "una fila di camion, uno appoggiato al paraurti dell'altro, che va da Caserta a Milano" [a line of trucks, bumper to bumper, that runs from 
Caserta all the way to Milan] (312) ? $^{3}$ The human mind has evolved to cope with human-like proportions and extreme magnitudes overwhelm the imagination but we now inhabit an increasingly interconnected and complex society which challenges us to overcome the implicit limitations of our instincts. In Becoming Animal (2011), David Abrams attributes modernity's destructiveness to the fact that the symbolism of writing has provided a vantage point which has enabled Homo scribens to distance itself from material reality, appropriate it, and manage it as if from above and beyond (Abram 281). The power of metaphor enables white collar criminals to make human suffering invisible on paper, and to argue that short-term profit is more real than the destruction they commission. However, the same power can perhaps be harnessed to render the description of their crimes vivid and real so that they acquire a life of their own in the reader's imagination. Cynicism is exceedingly easy when we are faced with impersonal accountancy. By turning abstract numbers into familiar images, Saviano not only recreates Gomorra's reality in the reader's mind, but also steeps it in the emotive, awakening his readership to the material drama which unfolds in the Land of Fires.

However, there is one more technique that Saviano employs to bring his readers even closer to his reality. Our most immediate interface with the environment are our senses, and Gomorra often employs what Wu Ming define a "sovraccarico" [overloaded] point of view, saturating the prose with sensory inputs (Wu Ming, New Italian Epic 26). The geography of the Land of Fires is vast and varied, and some spots draw the narrator's attention in a special way. As Saviano leads the reader deep into the Land of Fires, the appeal to materiality becomes more powerful as the tortured land oppresses the senses of narrator and reader alike, mingling them in a kind of unsettling synaesthesia. Where piles of paper used to clean cows' udders form yellowish hills, the smell is faint and organic: "[q]uando passavo per le colline di carta di mammella, sentivo puzza di latte andato a male. Forse era solo suggestione, forse quel colore giallastro delle carte ammonticchiate deformava anche i sensi"

\footnotetext{
${ }^{3}$ More than $750 \mathrm{~km}$ of roads separate Caserta from Milan.
} 
[perhaps the heaps of yellowish udder paper distorted my senses, but they smelled like sour milk]. In other areas, the olfactory stimulus overwhelms the others. Where the soil had been mixed with carcinogenic hexavalent chromium, "[1]'odore era acido e forte, ed esplodeva ogni volta che pioveva" [[e]very time it rained, a strong, acid smell blossomed]. The inescapable material consequence of economic activity are just like the mountains of waste. Saviano calls his readers attention to the fact that the noxious smells haunting the Land of Fires are the inescapable olfactory metaphor of industrial activity: "[p]asseggiare nell'entroterra campano è come assorbire gli odori di tutto quanto producono le industrie" [ [w] walking in the Campania hinterlands, one absorbs the odors of everything that industry produces] (Saviano 314). Saviano engineers his narrative so as to explore "the entanglements between material configurations and the emergence of meanings", to tread the threshold between perception and word, and between the unsettling materiality of the Land of Fires and the reader's mind (Iovino, "Material Ecocriticism" 56 ). In so doing, he reminds his readers that, whilst they may be cosily snuggled in their favourite armchair, immersed in an engaging read, they belong to the same reality as him, an inhabitant of Gomorra; that there is no impassable frontier between the horror of the Land of Fires and their most intimate sanctum sanctorum; that they will not be able to forget the tragedy of Gomorra.

\section{My Name is Legion: for We Are Many}

The Camorra is a vast organisation with Casal di Principe and the Land of Fires lying at its epicentre. Its interests span all five continents and infiltrate all institutions, whether public or private. And yet, notwithstanding the far-reaching nature of the phenomenon Saviano chose to illustrate, the firstperson narrative is predominant in Gomorra. As Saviano describes Gomorra, we experience with him its toxic landscape. We can almost smell the acrid smoke rising from thousands of blazing fires. We can see the mountains of whiteware, burnt cars, furniture, and barrels still leaking toxic fumes, all littering the Neapolitan countryside. Saviano not only writes to inform but also to 
induce readers to indignation at the words of the stakeholder, and feel pity for the teenagers who wilfully expose themselves to the toxic cocktails almost as though it were a praiseworthy rite of passage. This use of a "punto di vista "sovraccarico»" [overloaded point of view] is an instance of the NIE's "sguardo obliquo" [oblique gaze] and has wide-reaching consequences within the text (Wu Ming, New Italian Epic 26, 29). Reliance on the first-person is a mechanism through which Saviano boosts the emotive impact of his text and, by using it extensively, he suggests that he is talking in earnest and with expertise (Hancock and Woodworth 331). Through the use of first-person narrative, accompanying the reader through the land of the fires, Saviano builds intimacy, and therefore trust which lies its foundation on truth.

But who is this narrating " $\mathrm{I}$ "? Claudia Boscolo notes that Saviano "narrates events he did not witness as if he experienced them personally" (22). In fact, Gomorra's author is only apparently an embodied narrator: the attentive reader soon realises that "Roberto Saviano" is but a very skilful ventriloquist: Gomorra's disembodied narrator is "una sintesi, un flusso immaginativo che rimbalza da un cervello all'altro, prende in prestito il punto di vista di un molteplice" [a synthesis, an imaginative flux that bounces from one brain to another, and borrows the point of view of a multiplicity] (Wu Ming 1 and Wu Ming 3). Moreover, Antonio Scurati writes, Saviano takes on "una postura epica quando si fa testimone autoptico di tutte [le storie] garantendo per esse in prima persona (fino alle estreme conseguenze)" [an epic posture when he turns into an eyewitness of all [the stories], guaranteeing for them in the first person (whatever the consequences)] ("L'epica è rediviva e lotta insieme a noil"). Thus, far from endangering the reader's trust, this literary strategy enhances the reading experience, placing the reader in the middle of the action. Although Saviano's metamorphoses are not as extreme as those of Italo Calvino's shapeshifting Qfwfq, the two characters share their lack of definiteness, travelling unimpeded through time and space (and form), relaying their story, which is not the tale of a single entity, but that of a multitude. Saviano is an "everyman": an ordinary Neapolitan facing extraordinary circumstances. Because of this, he does not just 
expose the Camorra, but also speak for the whole Neapolitan people whom the Camorra oppresses. As a consequence, he breaks omertà in the most explosive way.

\section{A Patchwork of Stories}

There is an ancient Indian story about six blind men trying to understand what an elephant looks like by touching it. The six men, who touch different parts of the animal, all come to apparently irreconcilable conclusions: the man who comes by the chest comes to believe that the animal is a wall; the man who touches the elephant's tusk thinks that it is a spear; the one holding its trunk is convinced that the elephant is a snake; and so forth for the legs (perceived as trees), the ears (fans), the tail (a rope). The story illustrates the dangers of exploring reality from a single point of view and the need to acquire different perspectives.

One recurring feature of these stories is the inability of Gomorra's inhabitants to perceive the bigger picture beyond their immediate surroundings, which prevents them from addressing the real causes of their suffering. Indeed, the multiple stories of Gomorra show that wilful ignorance is the Camorra's best ally, and the people's worst enemy, and it is apparent that all those who deal with organised crime are creating lies for themselves (and for others) to avoid looking at the raw reality they are immersed in. Franco the stakeholder tells himself (and his apprentice) that, by providing industry with cheaper waste disposal, he is helping factory workers to keep their jobs (321-322). Then, Saviano the character/narrator meets a barman whose patrons are the boys the Camorra recruits to move waste so toxic that no one else wants to touch it. Even though they feel tough now, no-one of these boys, Saviano writes, "neanche per un istante, poteva immaginarsi dopo una decina d'anni a fare la chemioterapia, a vomitare bile con stomaco, fegato e pancia spappolati" [could imagine, not for an instant, that in ten years time they'll be getting chemotherapy, vomiting up bile, their stomachs, livers and intestines reduced to a pulp] (329). Finally, Saviano writes about the desperate homebuyers who purchase cheap houses 
from the Camorra knowing well that they have been built on illegal dumps filled to the brim with the burnt remains of tonnes of waste (327). Saviano-narrator is an indefinite and shape-shifting entity able to change his point of view with uncanny swiftness so while Gomorra has been written down as a single work, it is entirely possible to read it as a collection of stories. This is not so much Saviano-author's story as the story of the places Saviano-narrator (temporarily) inhabits and the stories of the other (more permanent) inhabitants of such places. In particular, these three episodes (among others) make it clear that selfdeception is the primary ingredient of the chemical and social witches' brew the inhabitants of the Land of Fire characters float in. Thus, Saviano's oblique point of view offers a vantage point through Gomorra allowing the reader to behold the hidden mosaic of stories that the single entities populating the Land of Fire form.

On the one hand, the inhabitants of the Land of Fire have learnt to deceive themselves in order to coexist with the Camorra but, on the other hand, the criminal organisations have learnt that it is easier to do business when the guns fall silent. In 1993, Nunzio Perrella (the boss of the Rione Traiano Camorra gang) had already understood that stealthy slow violence is more profitable and less dangerous than military confrontation: compared with drugs, he said, the business of waste "[r]ende di più e soprattutto si rischia molto meno" [is more profitable and, more importantly, less risky] (Marino). The Camorra's change of strategy does not imply that they have stopped killing. On the contrary, Senior and Mazza's epidemiological study links a spike in cancer cases around Nola, Marigliano and Acerra to the release of enormous quantities of toxic waste in the soil, water and air (Senior and Mazza 3). Thus, while self-deception allows the Camorra to thrive unchallenged, the entombed waste beneath the Neapolitan orchards invisibly and silently, slowly but surely, releases its toxic payload irretrievably contaminating Campania felix and killing its inhabitants.

An unholy alliance between reckless business, corrupted politics, hardened crime and civic indifference has made possible the "constant and repeated apocalypse-routine" of the Land of Fire. (Saviano 328). But is the Land of Fire 
that alien? Surely I, Reader, am not so hypocritical as to feel outraged at the Camorra's heinous crimes while at the same time being responsible for them! Surely, the fact that my porous body absorbs their toxins makes me their victim, not their accomplice. Consider though: Carmine Schiavone told his inquisitor that the clans exist only because the State allows them to $4_{4}^{4}$ Saviano tells us that waste is the necessary product of economic activity, which the statespeople worship under the name of Gross Domestic Product. Jadel Andreetto points out that we should look in the mirror if we want to meet the instigator of many environmental crimes (see Appendix A “Intervista a Jadel Andreetto"). Whether or not one agrees with such a conclusion, there is a creeping suggestion within Gomorra: the new clans, having mostly switched blood-thirsty confrontation for subtler means, have been enormously skilful at infiltrating what are considered normal business practices. Unless we change our perceptions of what we consider "normal", the clans will keep flourishing at the expense of society. Modifying our perceptions of the normal is bound to place us outside of our comfort zones. The clans are betting on our inability to challenge our habits.

\subsection{Violent Metaphors: Delta blues}

Kai Zen is an ensemble of writers which includes Jadel Andreetto, Bruno Fiorini, Guglielmo Pispisa, and Aldo Soliani. They have authored Ti chiamerò Russell (2003) and La potenza di Eymerich (2004) in cooperation with Wu Ming and other writers. More recently, they have independently published popular titles such as La strategia dell'ariete (2007) and Delta blues (2010), which have been made available in various electronic formats on the group's website through the

\footnotetext{
${ }^{4}$ Since the assassination of Giovanni Falcone and Paolo Borsellino in the early 90s, organised crime has stopped trying to confront the state through high-profile intimidation and bloodshed, and it cannot be stressed enough that modern organised crime sees itself as a state within the State. When questioned about the relationship between Camorra and the State, Carmine Schiavone dismayed Massimo Scalia by professing that he made no distinction between the two, arguing that "la mafia e la camorra non potevano esistere se non era [sic] lo Stato... Se le istituzioni non avessero voluto l'esistenza del clan, questo avrebbe forse potuto esistere?" (Scalia 9,10 ).
} 
Creative Commons license CC-by-nc-sa, which enables anyone to freely copy and modify the text for non-commercial purposes as long as attribution and the same license are preserved in the derived texts (Creative Commons). The practice of releasing literary material under the Creative Commons licence was adopted by Luther Blissett and is continued by Wu Ming.5 The Creative Commons licence encourages the dissemination of ideas, and allows access to information worldwide to anyone who might need it for non-commercial purposes, without a requirement for monetary compensation.

Kai Zen's most recent book, Delta blues, has also been published in paperback by Edizioni Ambiente in the VerdeNero series. Delta blues is a rewriting of Joseph Conrad's Heart of Darkness (1902) which conveys a strong environmentalist and social message highlighting the plight of the people living in the Niger Delta, an ecosystem ravaged by the activities of transnational oil corporations. Martin Klein and Ivo Andriç, codenamed Tamerlano, are Delta blues' main characters. Klein is a geologist working for the multinational Ente, a transparent reference to the Italian corporation Ente Nazionale Idrocarburi (Eni), which has major interests in petroleum extraction in Nigeria. In an interview, Jadel Andreetto declared that they chose to mask the name of the corporation in order to "ripararci da eventuali ripercussioni legali" [protect ourselves from possible legal repercussions] (Appendix A "Intervista a Jadel Andreetto"). The narration swings between the points of view of the two main characters: Martin Klein and Ivo Andriç, both Ente employees. The former is an engineer whereas the latter is an Istrian secret agent with orders to find Klein - though it is never clear whether his intentions are to rescue or to eliminate him. From his reports and from Klein's emails to his daughter, we learn that Klein is interested in developing renewable energy sources in Nigeria. Unfortunately, his interest gains him enemies within the backward-thinking Ente, who enact a conspiracy

\footnotetext{
${ }^{5}$ Luther Blissett is a collective noun used by pranksters and artists alike during the 1990s. Blissett authored novels— the most famous being $Q$ (1999) — and claimed responsibility for several hoaxes revealing the bad faith and superficiality of the mass media. His creators determined that the character was to "live" from 1994 to 1999 and, in December 1999, committed symbolic seppuku.
} 
to silence him. Thus, Klein is sent away on a mission with the alleged goal of researching alternatives to oil in the Niger Delta but whose real purpose is to have him eliminated. But Klein soon vanishes in the depths of the jungle and is rumoured to have joined the local resistance against the oil corporations. Andriç is enlisted to find him. As the action proceeds, Andriç's chase leads him ever deeper into the horror of the Niger Delta, a formerly fertile ecosystem where everything reeks of death, oil, and corruption. Eventually, Andriç discovers that local resistance movements have begun to worship Klein as a papaloa, a witch doctor possessed of supernatural powers.

Though Delta blues is certainly a novel and not a documentary, it introduces the reader to some very real problems affecting the Niger Delta, an area where strong Italian industrial interests are present but whose situation has been insufficiently covered in the news. Kai Zen make a strong connection between the climate of violence in the Niger Delta and the activities of the extractive industries, highlighting both the responsibilities of the local resistance groups and those of the corrupt government as well as the recklessness of the oil corporations. The bibliography included at the end of Delta blues is an open invitation to readers to further research this topic.

Although separated by more than a century, both Heart of Darkness and Delta blues explore the damage of (neo)colonialism and resource imperialism. In this regard, Delta blues shows that the more things change, the more they are the same: whereas in the nineteenth century colonial powers looted Africa for ivory, in the twenty-first, multinational corporations loot Africa for oil-in both cases leaving behind grief, misery, and devastation. The 2006 United Nations Development Programme (UNDP) reports that the Niger Delta suffers from "administrative neglect, crumbling social infrastructure and services, high unemployment, social deprivation, abject poverty, filth and squalor, and endemic conflict", and finds an "inverse relationship" between development trends and economic growth based on oil and mineral production (9). In Nigeria as in other developing countries, a weak legislative framework and corruption prevent the fair redistribution of the wealth generated by mineral 
extraction. Moreover, inadequate legislation and law enforcement fail to curb the environmental and social harm that profit-driven multinational corporations perpetrate against place and inhabitants. In such cases, instead of an opportunity for the local population, the extractive industry has cast a "resource curse" upon the country - causing internal and international conflicts, increased economic inequality, political disengagement, corruption, and decline of existing manufacture and agricultural industries due to the sudden appreciation of the local currency (so-called Dutch disease). Kai Zen's novel explores how Nigeria's oil riches have turned into a resource curse for the inhabitants of the Niger Delta. Furthermore, as I shall discuss in the next pages, in Delta blues, Kai Zen use a specific language and narrative strategies that create awareness of important social and environmental issues.

\subsubsection{A Delta of Intersecting Texts}

In his essay titled "Una termodinamica della fantasia", Wu Ming 2 writes that "fino all'ultima pagina un libro ha bisogno di fiducia, oltre la copertina ha bisogno di ricerca" [until the last page, a book needs trust. Beyond the cover, it needs research] (New Italian Epic|189). Delta blues sends the reader on a horrific journey that shows the true cost of oil, including the externalities that firstworld citizens as well as corporations like to ignore, deny, and minimise. But where does fiction end, and fact begin, and why does it matter? Joseph Conrad described Heart of Darkness as "experience ... pushed a little (and only very little) beyond the actual facts of the case" (Jospeh Conrad, qtd. in Hochschild 143). The same could be said for Delta blues which, uncharacteristically for a work of fiction, includes a bibliography, allowing the reader to peek behind the scenes of Kai Zen's work (Delta blues 132). In it, works of non-fiction such as Gugliotta's Nigeria, risorse di chi? - Petrolio e gas nel Delta del Niger (2008) mingle with anthropological classics such as James G. Frazer's Il ramo d'oro (2006) as well as works of fiction. Web sources span the Italian news website Peace Reporter, the environmentalist TreeHugger, the Nigerian-hosted Nigerian Bulletin, and others. 
Finally, the filmography includes the documentary Delta Oil's Dirty Business as well as Francis Ford Coppola's Apocalypse Now Redux. Delta blues' declared sources are an invitation for the reader to investigate the situation of the Niger Delta, a region ravaged by environmental devastation, poverty, and violence.

Kai Zen invite their readers to navigate this intertextual web by creating charades and puzzles within the text so as to pique their curiosity and invite them to explore further. For instance, the names of many of the characters of Delta blues are references to other texts. In her introduction to Heart of Darkness, Joyce Carol Oates writes that Kurtz was named after Georges Antoine Klein, an employee of the Société Anonyme Belge pour le Commerce du Haut-Congo who died on the steamboat Conrad was piloting (Conrad, Heart of Darkness; The Secret Sharer 4-5). Thus, Andreetto says, in Delta blues, "Klein è stato chiamato Klein per Kurtz, ma in realtà è stato Conrad a chiamare Kurtz per Klein" [Klein was called Klein for Kurtz but in reality Conrad called Kurtz for Klein]. Nina, Klein's daughter in Delta blues, is a reference to Joseph Conrad's first novel, Almayer's Folly, where Nina is the name of Almayer's daughter (Appendix A "Intervista a Jadel Andreetto"). The anonymous "contabile" of Delta blue has his counterpart in the equally anonymous "Accountant" of Heart of Darkness. Finally, Kai Zen's choice of the name Tamerlano is a transparent reference to another English author, Christopher Marlowe, Tamburlaine's playwright, whose surname recalls Marlow, Tamerlano's alter-ego in Heart of Darkness. Through these references and puzzles, Kai Zen challenges readers to explore the novel's intertexts. Although such open-ended research may lead each reader to a different conclusion, it provides an invitation to learn more about the work and about the reality it sketches.

There is more than intertextuality to Delta blues. Kai Zen merge sources, points of views and even media types, so that their novel can be defined intermedial. This enables the reader to access the complex reality of the Niger Delta from many angles, through the eyes of many witnesses, and via various narrative registers. Delta blues' intermedial nature takes different forms within the novel, affecting and driving the plot in several ways. The narration swings 
between third person narrative, email correspondence, pages from a diary, and videos. It also takes the form of citations from epic sagas as well as comics and Elizabethan theatre. Furthermore, the whole novel is organised in acts and scenes instead of chapters, as if it were a play, and the " EXTRA\}" section is an actual theatre adaptation of the novel, a "Pièce per due attori e orchestra" [Play for two actors and orchestra] staged by the Compagnia Fantasma.

An instance of this intermediality is that Kai Zen inserts into the narrative the text of e-mails that the protagonist Martin Klein sends to his daughter Nina. When e-mail correspondence between Klein and Nina is interrupted after the engineer's capture, the narrative proceeds through the pages of a diary that Klein keeps during his imprisonment. This style of narration, which mingles epistolary novel with swashbuckling adventures, is reminiscent of Luther Blissett's $Q$ (1999), in which the reader peruses letters from Qoeleth to the bishop Gianpietro Carafa detailing his machinations to repress the heresies arising in Germany during the early sixteenth century. Epistolary narrative allows Kai Zen to tell Martin Klein's story from a point of view which would otherwise be unknown to the reader: that of a father's intimate exchanges with his daughter. Klein ceases to be simply an engineer working for the Ente, but becomes a multifaceted character who, in his private time, lets off steam and confesses to his daughter (and therefore the reader) thoughts, hopes, and fears.

Delta blues' intermedial nature also crosses the boundary of the written word to trespass into the realm of the visual. Kai Zen begin their novel with the reproduction of the Ramsund carving (figure 3.2), a piece of Norse art depicting the Völsunga saga, whose imagery is widely employed within the novel. The Völsunga saga tells the tale of Sigurd, a Norse hero who fights and slays Fafnir, a black poison-spewing dragon defending his treasure. As we shall see, the Völsunga saga plays a huge part in defining the imagery of the novel and in shaping Tamerlano's psychology. This is not merely a gratuitous reference to Norse literature, but a metaphor allowing the authors to express their political view.

By combining different media, Kai Zen provide several channels through 


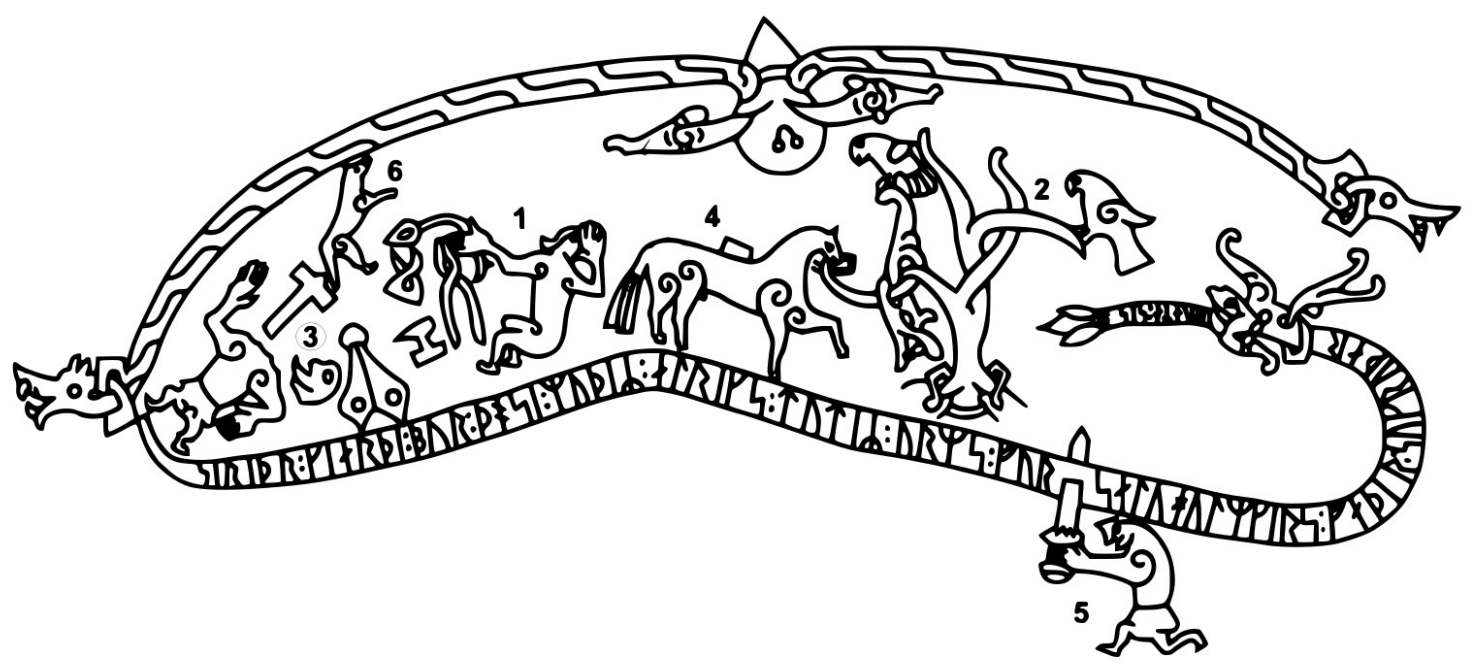

Figure 3.2: A reproduction of the Ramsund carving. Key: (1) Sigurd cooking Fafnir's heart and tasting its blood; (2) the birds singing to Sigurd about Regin's intention to betray him; (3) Regin beheaded, his smithing tools scattered about; (4) Sigurd's horse loaded with treasure; (5) Sigurd slaying Fafnir; and (6) Ótr, whose accidental death at the hand of the god Loki kickstarts the saga (Kai Zen, Delta blues 8). 
which readers can approach the Niger Delta. When Tamerlano meets the Belgian filmmaker Marguerite, he is shown chunks of footage from a documentary she is shooting. Instead of reporting the content of the video, Kai Zen adopt for the scene a visual type of narration which simulates the video itself, introduced and closed by the codes we may see on the screen of a videocamera, and constructed with short sentences indicating actions and verbless descriptive clauses:

: RVM 00-00 rec 6

L'immagine è indecifrabile, in movimento. L'audio confuso. Passi rapidi su terra bagnata, respiri affannati, rami che si spezzano, frusciare di fronde e piante. Poi una vertigine, un'iperbole che da terra si alza: un albero contorto, fogliame, uno spicchio di luce ...

Silenzio.

Un'eterna sospensione imprigionata in una manciata di secondi, un'inquadratura fissa, l'immagine trema. Effetto neve. Buio.

: RVM 17-23 stop :

[The image is undecipherable, moving. The audio is confused. Quick steps on wet soil, gasping breaths, breaking branches, rustling fronds and plants. Then vertigo, a hyperbole which springs up from the soil: a twisted tree, leaves, a sliver of light ... Silence. An eternal suspension captured in a handful of seconds, a fixed shot, the image shakes. Snow. Darkness] (Kai Zen, Delta blues 47, 84).

This hybrid written-film register adds immediacy and thrill to the storytelling and enhances the emotional impact of the scene depicting the mass-murder of captives by militiamen with a flame-thrower.

Delta blues does more than tell the same story using multiple media: in fact its multimedial nature adds layers of complexity to the plot, making the

${ }^{6}$ RVM: Registrazione Video Magnetica [Magnetic Video Recording] 
narration more lifelike, drawing the contemporary reader further into the stream of events, and offering different points of view to the story without resorting to the artifice of an omniscient narrator. Narrative cannot give answers to political problems, but it can and it must ask genuine questions. Kai Zen do so by raising the thorny issue of the role of Italian industry in the Niger Delta. However, merely pointing out common responsibilities does not by itself help with solving complex problems. Kai Zen invite their readers to find solutions by pointing toward the galaxy of texts which have contributed to create Delta blues, suggesting that reading their novel should be only the first step in the personal path to understanding the raw truth about fossil fuel consumption.

\section{The Metaphor as a Broken Bridge to the Invisible}

The mind loves metaphors, and in fact metaphors are an important mechanism that enables us to understand the world. However, it is necessary to be aware of the limits of such a mechanism. George Lakoff identifies in metaphor "the main mechanism through which we comprehend abstract concepts and perform abstract reasoning" (244). In Delta blues, fictional elements are effectively metaphors used to highlight real issues that readers would otherwise struggle to understand because their cause is too removed from the effect. In Heart of Darkness, Joseph Conrad compares the Congo river to an "immense snake uncoiled, with its head in the sea, its body at rest curving afar over a vast country, and its tail lost in the depths of the land" to signify both the river's geography and its mystery (Heart of Darkness 10$)$. Kai Zen expand Heart of Darkness' metaphor of the snake by drawing the image of the dragon Fafnir from the Icelandic Völsunga saga. When meeting the saga's hero Sigurd, Fafnir thus introduces himself: "[a] countenance of terror I bore up before all folk, after that I brooded over the heritage of my brother, and on every side did I spout out poison, so that none durst come anight me" (Magnússon and Morris 62). Fafnir jealously hoards its treasure at the same time inspiring terror and spewing poison all around him. In Kai Zen's novel, the Niger river becomes Fafnir:

il fiume si mostrava in tutta la sua portata come un drago. Fáfnir, il 
serpente che avvince, che abbraccia il tesoro. La nemesi incarnata della Saga dei Volsunghi, una lunga serpe azzurra che spalanca le fauci immonde, mostrando la chiostra di denti con cui azzanna il mare, pronta a inghiottire chiunque si creda Sigurd [the river showed itself in all its might like a dragon. Fafnir, the constrictor snake who embraces the treasure. The living nemesis of the Völsunga saga, a long blue serpent with foul gaping jaws, showing the circling teeth with which it bites the sea, ready to swallow whoever thinks himself Sigurd (Delta blues 17$)$.

Fafnir/Niger poisons the people living on its shores while it greedily hoards the profits coming from the exploitation of the nation's oil reserves. The metaphor of Fafnir enables Kai Zen to introduce the complex topics of petroleum pollution and slow violence in the Niger Delta without sacrificing narrative momentum. In addition, the metaphor allows the readers to visualise and connect with the environmental and social impact of petroleum extraction in the Niger Delta, while letting the authors avoid the dense language of scientific prose which would likely discourage some readers from investigating the issue.

But if Fafnir is the Niger river, who is Sigurd? While navigating the river, Tamerlano ineffectively mulls the question: "Fáfnir si dispiegava sulla mappa come una sinuosa linea azzurra. Mi chiesi se Sigurd fosse Martin Klein, o se invece non lo fossi io" [Fafnir unfolded on the map like a sinuous blue line. I asked myself whether Sigurd was Martin Klein, or if instead it was me] (Kai Zen, Delta blues 54). Lost on the great river, Tamerlano tries to apply Western frames of reference to the perceived chaos, but his efforts are frustrated because the Niger Delta is revealed as alien to such Eurocentric characterisation: "era solo uno dei tanti segnali che non avevo percepito, che non avevo osservato. Mi ritrovavo punto a capo, lo scarafaggio sul marmo. Qualcuno aveva manipolato il mito, e la narrazione mentiva. Sigurd era stato sconfitto e divorato da Fáfnir" [it was only one of the many signs that I had not perceived, that I had not observed. I was back to square one, a cockroach on marble. Someone had manipulated the myth, the narrative lied. Sigurd had been defeated and devoured by Fafnir] 
(101). Only too late does Tamerlano manage to solve the riddle but, again, the answer appears to be a subversion of the European myth of human supremacy over the forces of Nature which Fafnir impersonates:

Mi giro verso l'acqua, la sagoma d'ebano dell'arlecchino è seduta su un tronco che galleggia all'incrocio di due affluenti. Interrompe l'arpeggio alla chitarra, tocca la falda del capello in segno di saluto: "À bientôt Tamerlano." Il fiume scintilla come la pelle di un serpente, ha scaglie oleose, iridescenti, solcate da arcobaleni di benzina, fiammate di gas flaring e lische di pesci preistorici. Sigurd svanisce nella tenebra, sul dorso di Fáfnir [I turn towards the water, the ebony silhouette of the harlequin sits on a floating log at the meeting of two tributaries. He interrupts the guitar arpeggio, touches the brim of his hat as a greeting: "À bientôt Tamerlano." The river sparkles like the skin of a snake, it has oily scales, grooved with petrol rainbows, gas flaring flames and prehistoric fish-bones. Sigurd vanishes in the darkness, on Fafnir's back] (Kai Zen, Delta blues 124).

In the Völsunga saga, Sigurd, a handsome Nordic warrior, receives the sword Gram as a gift from the god Odin, and with that weapon he is able to slay the evil dragon Fafnir. But the real hero of Delta blues is revealed to be Ade, a Beninese ex-fisherman and musician, whom Tamerlano calls "l'arlecchino" [the Harlequin], whose cunning allows him to neutralise Klein's mad and violent ambition and to peacefully ride the dragon. Tamerlano's failed attempt to interpret the Niger Delta through a Eurocentric framework shows that we cannot understand the Niger Delta unless we slip out of habitual thinking patterns that assume that confrontation is the best means to overcome the challenges that Nature offers to humanity.

\subsubsection{Fast and Slow Violence}

"[O]wari yokereba, subete yoshi" [the end justifies the means] says Taro Shibuya, the mysterious Italian-Japanese contractor to whom the Ente entrusts the job of 
finding Martin Klein (Kai Zen, Delta blues 12). Or does it? Two questions ensue from the deconstruction of the contractor's phrase: first, what is the meaning of the word "end"? And second, who reaps the consequences of the "means"? The former question is somewhat rhetorical. Henry D. Thoreau wrote in Walden, or Life in the Woods (1882), that "the principal object" of industrialisation is not the public good, but "that the corporations may be enriched", adding that "[i]n the long run men hit only what they aim at" (44). This holds true nowadays, so much so that fossil fuel corporations turn the highest revenues among all human enterprises. Royal Dutch Shell tops the Fortune 2013 Global 500 , and four out of the five following entries are petroleum corporations ( $\overline{\mathrm{CNN}}$ Money). Thus, we know that the final loyalty of any corporation is towards its shareholders. However, it is legitimate to enquire whether corporate pursuit of profit generates any victims. In other words, who pays the real price of the corporations' "means"? Kai Zen attempt to answer this question in their novel by showing what fossil fuel extraction means to the populations living on the Niger Delta.

In the Niger Delta, the development of mineral resources has generated a sense of frustrated justice and inequity, and the destruction of agriculture, a traditional source of income for the local population, has generated unemployment and poverty, leading to soaring violence. The government and petroleum corporations have often directly and indirectly contributed to escalating violence. A Nigerian government memo reads: "Shell operations still impossible unless ruthless military operations are undertaken for smooth economic activities to commence" (Nixon 103). The UNDP expresses "no doubt that the incidence of conflicts may have been considerably less if there had been no oil and gas in the region" (United Nations Development Programme 22). It further reports that "[t]he Niger Delta is virtually in a state of siege", mainly because of widespread discontent and disillusionment as the extractive industries funnel oil wealth to the ruling elites and to foreign corporations while generating virtually no benefit for the local populations.

But another type of violence, which is subtler yet just as harmful, taints 
the Niger Delta: it is the violence that the petroleum industry has silently perpetrated for half a century against the Delta populations through the "severe pollution of rivers and soils and the overall environmental degradation", which will inevitably haunt the area for decades, inhibiting legitimate economic activity, exacerbating conflict and corruption, and poisoning water, soil and air with toxins (112). As we have already seen, Robert Nixon describes slow violence as gradual, invisible, indirect, and delayed. Oil spills and gas flaring are unlike bullets fired from a gun. Both kill, but the latter murder visibly, noisily and instantly. Most importantly, it is possible to immediately draw a causal connection between whoever pulls the trigger and the victim. The former, on the other hand, kill quietly and invisibly: when toxins enter aquatic or land ecosystems, animal life is destroyed, plants choke and wither. This is just the beginning, because ecosystems sustain human communities. Suddenly, crops sown on tainted soil rot, livelihoods are lost. Toxins and carcinogens from polluted water, air and contaminated food pass through porous bodily membranes to reach internal organs where they slowly begin sabotaging cellular processes. Years and even decades may elapse before symptoms become apparent. The damage slow violence causes is temporally removed from its causes and thus it is easier to hide and rationalise. But even when the petroleum companies leave, their "legacy continues to seep into the environment and bodies of the local farming community that, unlike the international corporation, has nowhere else to go" (Nixon 107). Thus, in the Niger Delta, the development of mineral resources has generated a sense of frustrated justice and inequity, and the destruction of agriculture, a traditional source of income for the local population has generated unemployment and poverty, leading to soaring violence.

Nixon dedicates a whole chapter to the plight of the Ogoni, a people who live on the ground zero of the petroleum industry. His analysis focuses particularly on Ken Saro-Wiwa, the Ogoni activist whom the Nigerian government hanged in 1995 along with the so-called "Ogoni Nine" because of their non-violent protest against the "deadly ecological war" which the oil corporations have 
waged against the Delta people (Saro-Wiwa, A Month and a Day 131). Prior to his judicial murder, Saro-Wiwa declared in an interview to Channel 4 that "[o]il companies have flared gas in Nigeria for the past thirty-three years causing acid rain ... What used to be the bread basket of the delta has now become totally infertile. All one sees and feels around is death. Environmental degradation has been a lethal weapon in the war against the indigenous Ogoni people" ("Without Walls'").

Due to its geography and ecology, the Niger Delta is a particularly sensitive area, and oil spills represent a dramatic problem from both a social and ecological point of view. The Niger Delta comprises the area covered by the natural delta of the Niger river and it includes four main ecological regions: the coastal sandy barrier ridge zone, the mangrove swamp zone, the freshwater swamp zone and the lowland rainforest zone. The Niger delta includes eight Nigerian states and is home to 500,000 people belonging to several heterogeneous ethnic groups. The United Nations Development Programme's (UNDP) Niger Delta Human Development Report identifies five major ethnic and linguistic groups in habiting the Niger Delta: Ijoid, Edoid, Delta Cross, Yoruboid and Igboid, each of which includes several sub-groups (19-20). However, the ethnic composition of the Niger Delta is very different from that of Nigeria. Because of the Nigerian government's high level of centralisation, Delta minorities have virtually no institutional representation in Abuja. Nixon writes that "unelected officials from the three largest ethnic groups - the Yoruba, the Igbo, and the Hausa-Fulani - have totally dominated national politics". In addition, due to virtually exclusive reliance on petroleum as a source of national income, corruption and inequality are rife in Nigeria. 96 percent of Nigeria's export revenue and 80 percent of government income come from selling petroleum and 1 percent of the population controls 85 percent of such wealth (Nixon 106). Petroleum not only generates inequality, but damages traditional industries too. The Niger Delta was in colonial times a centre for the production of palm oil, cocoa, rubber and timber. However, "severe pollution of rivers and soils and the overall environmental degradation wrought by oil 
have led to the decline of crops" (United Nations Development Programme 125). In Delta blues, the reader explores the Niger Delta through Klein's and Tamerlano's eyes, observing the devastating effects of petroleum pollution on the local ecology and on its inhabitants.

Notice how the dry prose of the UNDP report compares with the descriptive language of the novel:

Pesce non me ne voleva dare. Disse che era avvelenato. Alcune famiglie di un villaggio non molto distante si erano intossicate poco prima e un bambino era morto di dissenteria. "Quando lo peschi è coperto di grasso grigio e puzza come il fondo di un barile di cherosene. La gente ha fame. Lo mangia lo stesso. Succede anche con i coccodrilli. Devo macellare i polli o comprare la carne secca dei nomadi. Una volta avevo delle capre, ma bevevano l'acqua fluviale" [He did not want to give me any fish. He said it was poisoned. Some families in a village not far away had been recently intoxicated and a child died with dysentery. "When you fish it, it is covered in grey grease and stinks like the bottom of a kerosene barrel. People are hungry. They eat it anyway. It happens with crocodiles too. I have to slaughter the chickens or buy dried meat from the nomads. Once I had goats, but they drank river water"] (Kai Zen, Delta blues 66).

Kai Zen place their readers right in the centre of the action, activating their empathic responses as they face likely situations and characters, as opposed to describing the reality of the Niger Delta from outside in supposedly neutral terms, a narrative mode which cannot but increase the reader's alienation from its inhabitants and their plight.

\section{Watching the Delta through Many Eyes II-The Author}

Kai Zen are an ensemble of Italian writers, so their narration necessarily reflects their Western cultural background. In the novel, Marguerite Cleenewerk embodies such partial point of view: "Marguerite era lo sguardo che abbiamo 
avuto noi Kai Zen nel guardare i documentari, cioè la curiosità di andare a vedere, di infilarsi nei casini pur di raccontare questa storia" [Marguerite was the gaze that we Kai Zen adopted while watching the documentaries, that is the curiosity of going to see, even to get into trouble just so as we could tell this story] (Appendix A “Intervista a Jadel Andreetto"). Her inclusion among the characters allows Kai Zen to vindicate the necessarily partial and faulty point of view of the authors instead of adopting a contrived and dishonest semblance of objectivity. Such vindication is one of the fundamental characteristics of NIE: Wu Ming 2 explains that, "[n]el nostro mestiere di narratori, credo che l'onestà intellettuale stia nel dichiarare il punto di vista ... Se io dichiaro questa prospettiva, allora anche una narrazione necessariamente parziale può diventare utile per tutti [in our craft of narrators, I believe that intellectual honesty lies in declaring the point of view ... If I declare this perspective, then even a necessarily partial narrative can be useful to everyone]" (Appendix C“Intervista a Wu Ming 2").

Marguerite pays a huge price for her curiosity in Delta blues and (like many of the novel's characters) goes through a violent cathartic process which reshapes the way she faces the world. At the beginning, she is described as a strong woman: a "reporter d'assalto che da anni girava l'Africa e da qualche settimana tentava di portare a casa un lavoro sul Movimento per l'emancipazione del Delta del Niger" [a newshound who had travelled Africa for years and for several weeks ago had been trying to complete a job about the Movement for the Emancipation of the Niger Delta] (Kai Zen, Delta blues 35). She appears ready to find the truth by any means, and tries to exchange sex for information with Tamerlano:

si avvicinò fino a respirare del mio respiro, gli occhi color ruggine piantati nei miei e un mezzo sorriso. Mi slacciò la patta e infilò la mano nei boxer. Un leggero movimento ritmico di indice e medio, senza mai abbassare lo sguardo. “Non prenderla sul personale. È solo lavoro. Ottengo sempre quello che voglio." [she came near until she breathed my breath, her rust-coloured eyes planted into mine 
and a half-smile. She unzipped my fly and inserted her hand into my boxers. A slight rhythmic movement of index and middle finger, without ever lowering her gaze. "Don't take it personally. It is only work. I always get what I want."] (Kai Zen, Delta blues 46)

But what she finds out in Niger Delta overwhelms her and she goes through the death of a friend and rape (Kai Zen, Delta blues 80, 95). However, Marguerite survives and she comes out of the experience deeply changed. At the end of the novel, Marguerite Cleenewerck calls Nina, Klein's daughter, to hand her the recording of her father's last farewell which, the text suggests, contains an indictment of the Ente's responsibilities in the Niger Delta. Compared with her boisterousness at the beginning of the novel, Marguerite seems now to have changed into a stronger, quieter, wiser person. Nina can feel her kindness through the phone, and because of that, she agrees to talk with her: "Non era stata una frase o una parola in particolare, ma una sfumatura della voce, qualcosa di indefinibile" [It was not a phrase or a particular word, but a nuance of the voice, something undefinable] (127). When they finally meet, Marguerite offers Nina advice on how to use the information that her father bequeathed to her, an offering and a choice of words which would sound completely out-ofcharacter were the old Marguerite speaking: "Non si può affrontare la tenebra con la tenebra. Alle volte ci vuole un cuore gentile" [You cannot confront darkness with darkness. Sometimes you need a kind heart] (128).

Kai Zen explicitly set Marguerite's character up to reflect their own experience in learning about the situation of the Niger Delta. In describing Marguerite's catharsis from boisterous confidence to quieter wisdom, they describe their own traumatic awakening to the complex reality of the Niger Delta. In addition to that, Marguerite is one of the few characters whose point of view a number of Italian readers may empathise with. Andreetto explains that "Klein è un genio, ma è pazzo, mentre la coscienza di Tamerlano non corrisponde con quella che potrebbe essere del lettore ... Marguerite è un po' lo sguardo dell'europeo che guarda queste cose con una certa coscienza" [Klein is a genius, but he is mad, whereas Tamerlano's conscience does not 
correspond to what the reader's may be... Marguerite is a bit the point of view of the European who looks at these things with some conscience] (Appendix A "Intervista a Jadel Andreetto"). From such assertions it is possible to infer that Kai Zen believe that their novel will in fact contribute not only to inform, but also, in some way, to awaken their readers to their role in the drama of the Niger Delta.

\section{Watching the Delta Through Many Eyes III—Nigerians}

Much of the violence and environmental degradation affecting the Niger Delta ensues from the petroleum companies exploiting Nigeria's weak political and judicial frameworks in the pursuit of higher profits at the expense of the river people. There is nothing new in the concept that imperialistic greed causes much damage in faraway lands. During the colonial era, nation-states sought to increase their influence and wealth by expanding their reach through military control of colonies, enslaving the locals and seizing raw materials. Joseph Conrad's Heart of Darkness illustrates the brutality of Belgian colonial rule in Congo:

They were dying slowly - it was very clear. They were not enemies, they were not criminals, they were nothing earthly now - nothing but black shadows of disease and starvation, lying confusedly in the greenish gloom. Brought from all the recesses of the coast in all the legality of time contracts, lost in uncongenial surroundings, fed on unfamiliar food, they sickened, became inefficient, and were then allowed to crawl away and rest. These moribund shapes were free as air - and nearly as thin (Heart of Darkness 25).

The worldwide political reshuffle which followed World War II encouraged claims of independence in many colonies, kickstarting the process of decolonisation, but colonialism was not over. The developed world still exerts a disproportionate if indirect power over developing countries and has been implicated in deposing democratically elected governments as well 
as in supporting dictators and kleptocrats. Multinational corporations have become actors, too, in this neo-colonial scenario, seeking to maximise profits by exploiting cheap workforces and weak legal frameworks in developing countries.

Indeed, the premise of both Heart of Darkness and Delta blues is to illustrate the horrors of (neo)colonial domination. However, while the similarities between the two books are striking, so are the differences. In Heart of Darkness, "il negro non parla mai, non ha coscienza, è una specie di oggetto" [the black person never speaks, has no conscience, is a kind of object] (Appendix A “Intervista a Jadel Andreetto"). Conrad's "savages" only utter "a violent babble of uncouth sounds" or exchange "short grunting phrases", speaking a mangled English in two occasions only: when craving human flesh and to announce Kurtz's death (Conrad, Heart of Darkness 7, 28, 65, 66, 116; Hamner 122-123). It is true that Delta blues is a rewriting of Heart of Darkness and that there are important plot similarities between the two. However, it would be unthinkable for Kai Zen to represent the indigenous characters in the same terms: Kai Zen's black characters are very different indeed, a far cry from Joseph Conrad's "savages". Zainab Amodu, Sunday, and even minor characters such as Makiwa and Johnny Saa, are articulated and full-rounded human beings with desires, goals and a personality. Whereas Heart of Darkness' "savages" were too passive to resist Belgian penetration, Delta blues' Nigerians are not "dispost[i] a farsi colonizzare, vuoi per ideale o per interesse" [prone to letting [themselves] be colonised, be it because of ideals or because of interest]. (Appendix A “Intervista a Jadel Andreetto"). In contrast, characters in Delta blues reflect the whole range of human behaviour, from the idealist to the cynical, to the corrupt. Thus, although inhabiting a society mired in corruption, Kai Zen's black characters cease to be an indefinite tawny mass of bestiality, and become rounded, human characters struggling for emancipation and challenging the Western colonisers with pivotal roles in Klein's epiphany and in Kai Zen's novel.

Such a rich description of the local population allows the authors to use different characters to display the multiple facets of the local society 
and the challenges that this society must face under the pressure of a degrading environment. Questions of environmental justice lie at the very core of Delta blues and Kai Zen mainly voice these concerns through the character of Dr. Zainab Amodu. She is a cynical and disillusioned professor of Environmental Impacts at the University of Lagos, whom Martin Klein meets during his journey, and who is instrumental in shaping his perceptions of the responsibilities of the extractive industry in the pollution of the Niger Delta. Kai Zen created Zainab in order to "spiegare la situazione senza appesantire il romanzo" [explain the situation without overloading the novel]. Zainab, Andreetto adds, was a way to introduce a point of view which is "altro" [alternative] from the European point of view, and "interno" [internal] from the African one. Zainab explains that there are two main causes for the pollution of the area: one is the decrepitude of the oil infrastructure and the other is the practice of gas flaring.

Zainab posò una mano sui tubi, la ritirò unta. I condotti essudavano il loro contenuto. Avevano un aspetto logoro. Zainab mi spiegò che l'intera rete veniva manutenuta solo in occasioni eccezionali e i piccoli gocciolamenti che avevamo visto non erano considerati tali. Ma era perlopiù colpa della fatiscenza di questi impianti se il petrolio stava lentamente avvelenando la regione [Zainab placed her hand on the pipes, and when she retracted it, it was greasy. The ducts exuded its contents. They looked worn-out. Zainab explained that the network was only maintained in special occasions and the small drippings that we saw were not considered as such. But it was mostly because of the disrepair of the rigs that oil was slowly poisoning the whole region] (Kai Zen, Delta blues 39).

Zainab's observations echo recent research into the causes of oil spills in Nigeria. Amnesty International reports that, "since the mid-1990s, SPDC has claimed that sabotage now accounts for as much as 70 per cent of all oil spills. The Nigerian Agip Oil Company has reported that 68 per cent of spills are attributable to 
sabotage" (Amnesty International 17).7However, Frynas finds that "[t]here are indeed strong indications that oil companies in Nigeria have used false claims of sabotage to avoid compensation payments" (128). Independent reports are few and far between because the oil corporations are the most powerful actors in the area and have a vested interest in showing as little liability as possible. In a 2008 report published in the Journal of Engineering and Applied Sciences, Adebayo and Dada identify several causes for the oil spillages that affect the region, attributing 25.65 percent to sabotage or vandalism; 56.33 percent to various forms of pipeline failure due to lack of maintenance, corrosion, material fatigue, or human error; 6.92 percent to third party accidental damage; 5.69 percent to natural forces (280). In his documentary film Delta, Oil's Dirty Business (2007), Yorgos Avgeropoulos links destitution, poverty, and a climate of violence with spills, but also highlights the huge responsibilities of the extractive industry in the degradation of the area.

Pipeline leakage is not the only environmental problem that affects the quality of life in the region. In Delta blues, Zainab introduces Klein to the damage associated with gas flaring, "la pratica di bruciare i gas che si estraggono insieme al petrolio invece di riutilizzarli" [the practice of burning the gases that are extracted together with oil instead of using them]. Oil companies find it cheaper to burn such gases instead of purifying and reselling them. Zainab explains that gas flaring "crea un inquinamento tremendo, causa di piogge acide, e in cambio la gente non ha niente. A parte i tumori e le malattie respiratorie e della pelle, chiaro" [pollutes terribly, causes acid rain, and in exchange the people receives nothing. Apart from cancers, respiratory and skin diseases, obviously] (Kai Zen, Delta blues 32). Again, research shows that there is little fiction in Zainab's words. Amnesty International reports that "Nigeria has prohibited gas flaring since 1984, unless a ministerial consent has been issued. Although the government has announced various deadlines for the cessation of flaring, each deadline has passed and flaring continues" (18). In the paper "Negative Effects of Gas Flaring: The Nigerian Experience", Anslem O. Ajugwo finds that "Nigeria flares 17.2

${ }^{7}$ SPDC: Shell Petroleum Development Company of Nigeria Limited 
billion $\mathrm{m}^{3}$ of natural gas per year in conjunction with the exploration of crude oil in the Niger Delta ... equal to approximately one quarter of the current power consumption of the African continent", causing "environmental, health, and social problems in local communities near oil producing fields" (6).

The second pivotal Nigerian character that Kai Zen create to picture the situation in the Niger Delta is Sunday, the local militia leader: while Zainab highlights the environmental consequences of petroleum extraction in the Niger Delta, Sunday allows the reader to visualise and understand its social consequences. The UNDP reports that Delta inhabitants "believe strongly that the environmental predicament contributes to social and economic deprivation", and that the government is unable at best and unwilling at worst to limit the damage brought about by the activities of the petroleum industry $(80,81)$. This discontent was left to brew for decades and culminated in the arrest and execution of the Ogoni Nine after they had presented the "Ogoni Bill of Rights" demanding environmental and sociopolitical reform (126). The failure of the Nigerian government to engage in a democratic process of reform led to a "youth crisis" where militias have been assembled to "prevent the oil companies from extracting oil without due regard for the environment and the people" (127). The most prominent of such militias is called MEND (Movement for the Emancipation of Niger Delta), which The Economist has described as "an umbrella organisation for several armed groups" that seek "a greater share of Nigeria's oil revenues to go to the impoverished region that sits atop the oil". Despite the idealism, MEND's revenues come from "gun-running" and from siphoning oil from pipelines, which is then sold to refineries overseas: "insiders in the oil industry reckon that as much as $10 \%$ of Nigeria's oil production, worth millions of dollars, is stolen each day" ("Risky toughness"). Andreetto claims that, in Delta blues, the leadership of the MEND are "scienziati, ingegneri, architetti" [scientists, engineers, architects]. I was unable to find any data in the literature to substantiate the claim that a sizeable percentage of MEND leaders are graduates. However, it is true that other terrorist organisations boast high literacy rates among their core affiliates. Marc Sageman found that, among "the 
Central Staff of the global Salafi jihad ... 88 percent had finished college and 20 percent had doctorate degrees" (75). For the plot of Delta Blues, the most important of these militants is Sunday. Kai Zen describe him as an educated and wily leader: "è un uomo orgoglioso, ha un suo codice" [is a proud man, he follows his own code] (Kai Zen, Delta blues 58). Sunday believes violence is his only choice:

“[h]o trentasette anni e due lauree. Ingegneria e informatica. Pensavo potessero servire per aiutarmi a fare strada nel mio paese, e magari ad aiutare il mio paese a uscire da questo... schifo. Sbagliavo." Riprese in mano il fucile, solo per un attimo: "Questo è molto più utile, mi sono accorto. Non è la soluzione, ma è più utile delle mie lauree. Però non sono un assassino, nessuno di noi lo sarebbe se ci venisse lasciata un'altra possibilità" ["I am 37 years old and I have two degrees. Engineering and computer science. I thought they would help me succeed, and maybe help my country out of this... mess. I was wrong". He took up the rifle again, just for a moment: "This is much more useful, I realised. It is not the solution, but it is more useful than my degrees. But I am not a murderer, none of us would be if we had the chance"] (Kai Zen, Delta blues 180).

Although he idealistically opposes the penetration of the extractive industries, he still earns money by protecting those who engage in bunkering, the illegal practice of piercing the oil pipelines to steal the crude and sell it abroad-an activity which often causes more spills (Kai Zen, Delta blues 51, 129; Amnesty International 13). In fact, Sunday admits, "era difficile distinguere il suo gruppo da una delle tante gang armate che operavano solo per denaro" [it was hard to tell his group apart from the armed gangs who were in it only for the money] (Kai Zen, Delta blues 51). But even though their illegal activities often aggravate the ecological problems that beset the area, the local population supports their struggle as they are perceived as the lesser evil. Again, this reflects the reality of the situation in the Delta: Daniel Howden writes in the Independent that MEND militants "enjoy widespread support as 20 million people remain rooted in 
poverty despite the enormous wealth generated in the oil-rich area" (Howden). In Delta blues, Sunday—scheming and cynical—is perfectly adapted to the socially and ecologically toxic environment he inhabits.

In Delta blues, black characters play the function of illustrating the problems that beset the region. However, unlike in Heart of Darkness, they are not faceless and voiceless savages. Many are highly sophisticated, educated, and emancipated (if somewhat cynical) — capable of using their skills to pursue their aspirations. In contrast with Heart of Darkness, the characterisation of black characters as thinking and sophisticated human beings facilitates the readers' empathy and identification with their plight. Jadel Andreetto likes to repeat that "le cose sono complesse" [reality is complex] and reason falters when attempting to understand a vast causal web such as the interaction between Niger Delta inhabitants, Nigerian government and multinational companies in the frameworks of history, politics and ecology. (Appendix A “Intervista a Jadel Andreetto"). Indeed, each character in Delta blues, regardless of their ethnicity, provides an oblique (and unique) point of view to the situation of the Niger Delta, so much so that Kai Zen's novel reads almost as an allegorical tale of greed, struggle and environmental destruction. Giving a face and a voice to the human beings who inhabit the Delta unmasks the crimes of the petroleum corporations, encourages readers' identification with men and women inhabiting oil-rich regions, and highlights the true price of petroleum-powered lifestyles.

\section{Death, Rebirth and Catharsis on the Niger Delta}

We have seen how violence, both fast and slow, and death are ubiquitous on the Niger Delta. The UNDP reports that "violence is unleashed randomly on unsuspecting communities or oil workers. Whole villages have been destroyed and their populace displaced because of disputes that could have been amicably resolved" and that "violence has become the prevalent means of resolving disputes in the region" (United Nations Development Programme 3, 118). Likewise, while the firefights which pepper the novel may add spice to it, the more the reader penetrates the depths of the Niger Delta, the more horror 
replaces excitement when realising the aftermaths of violence:

Cadaveri, decine di cadaveri, alcuni sono già scheletri, altri, non ancora del tutto decomposti, hanno le ossa ricoperte da putridume squagliato e nerastro. Cos'è questo inferno? Ade ammicca in direzione della foresta, dietro le mie spalle. Questo posto è più pericoloso di quello che sembra, mi dice, e ride. Alcuni mesi fa, questa gente si è trovata al posto sbagliato, nel momento sbagliato e soprattutto dalla parte sbagliata [corpses, dozens of corpses, some already skeletons. Others, not yet completely decomposed, have bones covered in liquefied and rotten black filth. What is this hell? Ade nods in the direction of the forest, behind my shoulders. This place is more dangerous than it seems, he tells me, and laughs. Some months ago, these people were in the wrong place at the wrong time and, most importantly, on the wrong side] (Kai Zen, Delta blues 108).

Death and horror are direct consequences of the violence that permeates the Niger Delta, and Kai Zen's novel illustrates how hundreds of lives are being lost due to conflict in the area. However terror-inspiring, death and horror are only part of the equation, just one of the multiple stages that Delta blues' characters go through, a process called "nigredo", which Kai Zen defines in the novel's glossary:

in alchimia significa putrefazione, decomposizione e rappresenta il fuoco esterno che, penetrato nel corpo, attiva il fuoco interno che inizia a putrefarlo riducendolo a quella materia di cui era composto in origine. In semiotica viene identificato come l'insieme delle difficoltà che l'uomo affronta e cerca di superare durante il suo viaggio all'inferno, ovvero all'interno di sé stesso. In psicologia è il processo in cui, attraverso l'utilizzo soprattutto delle emozioni, si ritrova l'auto-conoscenza [in alchemy, it means putrefaction, decomposition. It represents the external fire that, once it has penetrated in the body, activates the internal fire which begins 
to putrefy it, reducing it to the same matter it was composed of originally. In semiotics, it is identified with the set of hardships the individual faces and attempts to overcome during the journey to Hell, that is, inside the self. In psychology, it is the process through which, mainly through the use of emotions, self-knowledge can be found] (Delta blues 131)

This concept is not Kai Zen's invention, but rather an alchemical principle which Carl Jung adapted to his psychological framework, and which he defined as a "subjectively experienced process brought about by the subject's painful, growing awareness of his shadow aspects" akin to the process of acknowledgement and mourning discussed earlier (Ashton 231). Death, transfiguration and rebirth are strong forces driving Delta blues, manifesting themselves through Klein.

But although Klein's charismatic and necromantic powers become apparent as soon as he sets foot in Nigeria, he is himself a pawn of higher forces and eventually succumbs to them. After Klein is captured and brought to Sunday's camp as a prisoner, he meets Ade, who informs him that that he is a papaloa:

dalle mie parti quelli come te li chiamano ladri d'ombre. Cos'è un ladro d'ombre? chiedo ... I ladri d'ombre si mettono ai crocicchi, in attesa che passino le anime che si sono allontanate dal corpo di chi sta dormendo. Quando l'anima attraversa l'incrocio, il ladro d'ombre la fa sua ed essa non può più tornare al legittimo proprietario, una volta che il corpo di questo si sia risvegliato ... Non lo dirà a nessuno, a patto che gli insegni ["Where I come from, people like you are called shadow thieves". "What is a shadow thief?", I ask ... "Shadow thieves stand at crossroads, waiting for souls that have stranded from the bodies of sleeping people. When the soul passes through the crossroads, the shadow thief captures it and it cannot go back to the legitimate owner once its body had woken up" ... He won't tell anybody, provided that I teach him] (Delta blues 87) 
Klein never realises this, but the person Klein calls his "scudiero" [squire] is actually manipulating him, guiding him toward insanity, toward the consummation of his nigredo and that of those who surround him (Delta blues 103). In fact, for someone who is supposed to be a pupil, Ade seems to know a lot about black magic. First of all, as we have seen, he immediately recognises Klein's potential as a papaloa. Second, he teaches Klein how to build a "tsakatu", a death-fetish (104). Far from being a pupil, Ade is actually Klein's teacher in disguise. In fact, Ade [Hades] is the name of the Greek god of the underworld. Furthermore, Tamerlano calls Ade "l'arlecchino" [the Harlequin], a mask of the Italian commedia dell'arte typical of the city of Bergamo which enacts the animal side of human nature. But although the Harlequin is a comic mask, its origins are demonic. The probable etymology of the word "Harlequin" is through the Old High German "Hölle König" [Hell's king]. The figure of the Harlequin, or "Hennekin", is a demon appearing first in Ordericus Vitalis' Historia Ecclesiastica, which Dante subsequently places (under the name of Alichino) in the eighth circle, fifth ditch, guarding the barrators (Vitalis 515; Toschi 196-208; Alighieri and Zolesi Inferno, XXII, 112). Such connotations shed a somewhat sinister light on Ade. At the same time, as an agent of nigredo, Ade is no less than Exu, the Yoruba god of death, chaos and trickery, sometimes associated with the devil. Unlike Satan in the Christian tradition, Exu is not intrinsically evil: while it is true that his Black Work causes grief, it also offers wisdom to receptive characters.

But while Ade (through Klein) is the agent of nigredo, the transfiguring process is particularly visible in Tamerlano, and Tamerlano is the character who is most consciously aware of Klein's spell:

[1]e idee hanno un suono, come i metalli. Lo avevo letto anni addietro non ricordo più dove. Le idee di Klein dovevano vibrare e risuonare come campane di bronzo per gli uomini dell'Ente. Io le immaginavo più come mercurio, argento vivo. Qualcosa di alchemico in grado di innescare un processo di trasformazione. Chiunque fosse venuto in contatto con quell'uomo notevole sembrava non poter resistere al 
suo potere trasfigurante. Una forza capace di scatenare l'Opera al Nero, la nigredo, la morte dell'Io, la morte di tutti i desideri personali dell'allievo. E tutti quelli che avevano avuto a che fare con Klein, in qualche modo, erano diventati suoi allievi. Anche quelli che lo odiavano. Tutti loro erano cambiati [ideas have a sound, like metals. I read it years ago, but I do not remember where. Klein's ideas must have resounded like brass bells for the Ente's men. I imagined them more like mercury, quicksilver. Something alchemic capable of kickstarting a process of transformation. No one who came into contact with that notable man could seem to resist his transfiguring power. A power capable of unleashing the Black Work, the nigredo, the death of the self, the death of all personal aspirations of the pupil. And all who dealt with Klein, somehow, became his pupils. Including those who hated him. All were changed] (Delta blues 61).

Tamerlano is no exception and he, too, falls under Klein's spell-though the crucial difference is that he is poignantly aware of it, unlike most of the other characters, whom the nigredo overwhelms. Toward the end of the novel, Tamerlano realises that not much is left of his former self, which was destroyed during his journey towards the heart of the Delta. Having finally succeeded in finding Klein, Tamerlano reflects that he is not interested anymore in any reward the Ente may bestow upon him:

[c]apii che se avessi riportato a casa quell'uomo, mi avrebbero fatto capitano. Ma se lo avessi ritrovato morto sarebbe stato meglio. E così era. Ma ormai la nigredo aveva fatto effetto, Tamerlano non c'era più. $\mathrm{Al}$ suo posto, riemerso da chissà quale abisso, un me stesso ancestrale. Dimenticato, riaffiorato dalle domande di Klein [I understood that if I had brought back that man, they would have promoted me to captain. But if I had found him dead, it would have been better. And so it was. But the nigredo had taken effect, Tamerlano was no more. In his place, emerged from who knows which abyss, an ancestral myself. Forgotten, resurfaced by Klein's questions] (Delta blues 114). 
Explicit references to nigredo or, as I referred to it in my earlier discussion, mourning, suggest that Kai Zen are aware of the cathartic potential of experience and narrative. During our interview, Andreetto expressed the opinion that literature could elicit awareness of social and environmental problems even better than non-fiction (Appendix A “Intervista a Jadel Andreetto"). Thus, Tamerlano's cathartic journey from being an agent of the establishment through the hell of the Niger Delta to finding his true self may reflect and guide the reader's journey from comfortable conformity and avoidant emotional coping through the dimly-lit backstages of civilisation toward the realisation of the true price of our petroleum-fueled prosperity.

\subsubsection{Zen Archery}

Citizens of developed nations have grown so accustomed to considering a highpowered lifestyle as a birthright that proposing limits to individual power usage has become politically toxic. Politicians hesitate to mention the gradual but cumulative and thus potentially catastrophic consequences of burning fossil fuels, including climate change, local pollution, and deaths related to energy production. Mass media fail to report on such issues because slow violence does not conform with often sensationalist and superficial news reporting. Political interference in media and media interference with politics compound the case, as certain media groups have been known to use their influence to affect political decisions through the manipulation of public opinion.

It is said in Zen archery that the real target of the arrow is not the makiwara but the archer's self (Herrigel 9). 8 At the end of the Delta blues and at the zenith of madness, Klein compiles a list of people he would like to assassinate because they are somehow implicated in the destruction of the Niger Delta. In the list, he includes his personal enemies as well as "gli indifferenti, i neutrali, perfino $\mathrm{i}$ volenterosi dal cuore puro come la dottoressa Altafonte di Lagos. Su su fino ai più intoccabili dirigenti, a Roma. Perché tutti sono responsabili e per ciascuno, a

\footnotetext{
${ }^{8}$ Makiwara: straw practice target used in Zen archery.
} 
suo tempo, arriverà il redde rationem" [the indifferent, the neutral, even the purehearted and good-willed like Dr. Altafonte of Lagos. Up to the most untouchable executives, in Rome. Because all are culpable and for everyone, eventually will come the day of reckoning] and even "[g]ente che ho conosciuto, che ho incontrato, che ho visto. Gente di cui ho solo sentito parlare, perché no? Politici e saltimbanchi. Gente che vive nella convinzione che il conto lo paghi sempre qualcun altro" [people that I have known, that I have met, that I have seen. People that I have just heard about, why not? Politicians and mountebanks. People who live in the conviction that someone else will always pay the bill] (Kai Zen, Delta blues 103, 109). The list of culprits worthy of death piles up dizzyingly in Klein's sick mind, and the reader realises his madness. However, the suggestion remains that responsibility for the human and environmental disaster of the Niger Delta cannot be placed exclusively at the feet of the petroleum corporations. The arrow of guilt, ostensibly aimed at the target of the petroleum industry, hits back: "[c]osa succede quando, alla fine del giallo, scopro che l'assassino sono io? Perché in effetti l'ENI in Nigeria sta causando morti, malattie, una piccola apocalisse. Ma l'ENI sono io, l'ENI è una società a partecipazione statale." [what happens at the end of the detective story when I find out that I am the murderer? But I am ENI, ENI is a government controlled company] (Appendix A “Intervista a Jadel Andreetto"). 9 The implication is clear: consumers, stakeholders and voters are to a certain degree responsible for the unethical behaviour of corporations operating in Nigeria.

It is undeniable that contemporary living is completely dependent on hydrocarbons. Il Contabile [the Accountant] gloatingly reminds the reader that "anche i signori che ce l'hanno con noi, gli ambientalisti, i pacifisti, i terzomondisti, anche loro usano l'energia [even the ladies and gentlemen who resent us, the environmentalists, the pacifists, the Third-Worldists - they, too, use energy]" (Kai Zen, Delta blues 27). However, this is a specious argument.

\footnotetext{
${ }^{9}$ ENI: Ente Nazionale Idrocarburi. The Italian government owns a sizeable part of the company's shares, both directly through the Ministero dell'Economia e delle Finanze [Ministry of Economy and Finances] and indirectly through the Cassa Depositi e Prestiti [Deposits and Loans Fund] (Eni's Board of Directors 8).
} 
The fact that, as a society, we are dependent on fossil-fuel generated energy and materials does not preclude awareness, and awareness is the precursor of change. Delta blues is a conscious attempt to raise important points about consumption and personal responsibility, acting as a counterbalance to the business-as-usual discourse. One of the reflections behind the novel is that,

noi come cittadini del mondo sviluppato non abbiamo percezione di ciò che stiamo facendo all'altro, in questo caso la Nigeria, quando compiamo quotidianamente azioni a prima vista insignificanti come accendere il gas o fare il pieno alla macchina, perché non abbiamo alcuna consapevolezza della catena che sta dietro a queste azioni [we as citizens of the developed world have no perception of what we are doing to the other (in this case Nigeria) when we perform apparently insignificant daily activities like turning on the gas or filling up our cars, because we have no awareness of the causal chain that lies behind these actions] (Appendix A “Intervista a Jadel Andreetto").

Although Kai Zen are aware that literature has but a limited effect on society, Delta blues encourages readers' empathy through its fully-rounded characters and by depicting realistically the environmental devastation of the Niger Delta. Thus, the Niger Delta ceases to be a far-away land of which we know nothing, and becomes instead the home of people to whom we can relate. In this way, Delta blues highlights the crimes that petroleum corporations commit in the name of profit and under the guise of maintaining power-hungry lifestyles. But the crimes of the petroleum corporations, though abominable, do not absolve consumers. Awareness of our individual role in the plight of the inhabitants of the Niger Delta sabotages our denial and forces us to face the underlying guilt-perhaps a path to healing the self and society. 


\subsection{Previsioni del tempo}

The pseudonym "Wu Ming" is commonly used among Chinese dissidents and means either "no name" or "five names", depending on the tone of the " $w u^{\prime}$ syllable: when the intonation rises (pinyin: wú), it means "anonymous", when the intonation falls then rises (pinyin: wǔ), it means "five people". Although their real names are known, Wu Ming usually refer to individual components by placing a numeral after the band's name (in alphabetical order) when appearing publicly: Roberto Bui (Wu Ming 1); Giovanni Cattabriga (Wu Ming 2); Luca Di Meo (Wu Ming 3); Federico Guglielmi (Wu Ming 4); Riccardo Pedrini (Wu Ming 5). Wu Ming explain their choice of using pseudonyms and refusing to be photographed or filmed as a strategy to prevent media manipulation:

Once the writer becomes a face that's separate and alienated (in a literal sense), it's a cannibalistic jumble: that face appears everywhere, almost always out of context. A photo is witness to my absence; it's a banner of distance and solitude. A photo paralyzes me, it freezes my life into an instant, it negates my ability to transform into something else. I become a "character," a stopgap used to quickly fill a page layout, an instrument that amplifies banality. On the other hand my voice - with its grain, with its accents, with its imprecise diction, its tonalities, rhythms, pauses and vacillations - is witness to a presence even when I'm not there; it brings me close to people and doesn't negate my transformative capacity, because its presence is dynamic, alive and trembling even when seemingly still (Wu Ming, "The Perfect Storm, or rather, The Monster Interview").

This stance denotes a radical rejection of the cult of personality and a desire to focus the attention on literature and on what literature speaks about.

Wu Ming's entire production has been released under copyleft, which allows "la riproduzione parziale o totale dell'opera e la sua diffusione per via telematica, purché non a scopi commerciali e a condizione che questa dicitura sia riprodotta ... " [the partial or total reproduction of this book, in electronic 
form or otherwise, ... for non-commercial purposes, provided that the original copyright notice and this notice are included ... ]. Further to their effort in promoting the free circulation of literature, $\mathrm{Wu}$ Ming are noted for their stance on environmental matters, but Wu Ming 1 and Wu Ming 5 did the most to articulate the band's position on various ecological issues-from the anti-ethics of producing nuclear energy, to a critique of consumerism and capitalism, to calls for a more widespread use of recycled paper in publishing, and many others (Wu Ming 1, "'I posteri e il nucleare: la nostra etica puzza"; Wu Ming 5, “Non c'è un modo 'giusto' di produrre oggetti inutili"; Wu Ming, “Faremo la nostra parte"'). Since 2003, they have published their books on FSC-certified chlorine-free recycled paper, even postponing the publication of Guerra agli umani in 2003 because of their participation in the Greenpeace "Campagna foreste" [Forests campaign] ("Perché abbiamo rinviato l'uscita del romanzo di WM2 '). ${ }^{10}$ In 2004, they published “The Emperor's Three Hundred Woodcutters" for the Greenpeace Book Campaign, a short story about the relationship between trees, myth, and collective memory.

Previsioni del tempo is a short novel focusing on the business of waste, illustrated from the point of view of its "proletari" [proletarians], thereby offering an "oblique gaze" into the world of ecomafia (Wu Ming, Previsioni del tempo 43). Although Wu Ming signed the book as a whole, Previsioni del tempo's main authors are Wu Ming 3 and Wu Ming 5. In particular, Wu Ming 2 explains, Wu Ming 3 is Neapolitan and feels a special connection to the waste emergency in Naples.

Previsioni del tempo was commissioned and published by VerdeNero. Wu Ming 2 explains that Alberto Ibba, then director of VerdeNero, contacted them asking them to write a novel about ecomafia, and in particular the "ciclo dei rifiuti" [cycle of waste]. Once they began writing the novel, Edizioni Ambiente provided $\mathrm{Wu}$ Ming with documents regarding the phenomenon of environmental crime in Italy. Although Wu Ming was familiar with historical sources and used them extensively while writing their previous historical novels,

${ }^{10}$ FSC: Forest Stewardship Council. 
Wu Ming 2 admits that Previsioni del tempo posed new challenges and forced them to proceed in ways they were unaccustomed to:

non avevamo mai provato a lavorare con un archivio contemporaneo e specifico di un certo settore, in precedenza era sempre stata un'operazione fatta sulla storia e volevamo invece sperimentare lo stesso tipo di atteggiamento su un documento, un archivio [we had never tried to work with a contemporary and archive related to a specific sector. In the past, it was always an operation which we performed on history and we wanted instead to try out the same kind of attitude on a document, an archive] (Appendix C "Intervista a $\mathrm{Wu}$ Ming 2").

Previsioni del tempo was finally published in 2008 in the VerdeNero series but, like all other Wu Ming's novels, it is available for free download on Wu Ming's website 11

As in other works by Wu Ming, there is an important political aspect to Previsioni del tempo. Although the novel only partially adheres to the criteria that define NIE (see sections 1.4 and 2.2), Wu Ming 2 explains that "Previsioni del tempo risponde a quell'aspetto di responsabilità etica da parte del narratore, che in qualche modo si contamina, si sporca le mani e si impegna con il materiale che sta raccontando dove, in qualche modo, il raccontare è prendere posizione consapevole" [Previsioni del tempo responds to the aspect of ethical responsibility of the narrator who contaminates himself or herself, dirties her or his own hands, and engages with the material he or she is narrating where, somehow, narrating means consciously taking a position] (Appendix C “Intervista a Wu Ming 2 "). As I have previously highlighted, the authors' awareness of their ethical responsibilities is the most important aspect of NIE and an essential feature of the novels I discuss here (see 2.2).

Wu Ming consider Previsioni del tempo as a transmedial sequel to Guerra agli umani (2004): even though authors and editors are different, and the medium is

${ }^{11} \mathrm{Wu}$ Ming Foundation: http:/ / www.wumingfoundation.com 
the same in both works, ecocrime is a main theme in both novels (Appendix C "Intervista a Wu Ming 2"). Interestingly, many characters and places of Guerra agli umani appear again in Previsioni del tempo, namely Jakup Mahmeti and his motley band of jailbirds, as well as geographical names as both novels are set around the fictional Monte Budadda in the Apennines near Bologna. Moreover, both Guerra agli umani and its sequel Previsioni del tempo engage with different aspects of ecological crime: whereas Guerra agli umani focuses on dog fighting and poaching, Previsioni del tempo provides insight into the mechanisms of illegal waste disposal. "Oblique gaze", the adoption of unusual points of view, is a prominent feature of both novels. Guerra agli umani's main character is Marco 'Walden', a reference to both Calvino's Marcovaldo and Henry D. Thoreau's Walden; or, Life in the Woods. Marco 'Walden' is a young maladjusted man who becomes disillusioned with modern life and resolves to abandon the hustle and bustle of civilisation to become a "supereroe troglodita" [troglodyte superhero]: he quits his job, leaves his home and finds a dwelling in a mountain cave somewhere in the woods of the Appennine Mountains (Wu Ming 2, Guerra agli umani 7). Although determined to leave behind civilisation and its "inutensili" (a portmanteau of the Italian words for "useless" and "utensils"), he finds himself unable to renounce his music collection (and therefore batteries), matches, and cigarettes (64). Eventually, spurred by hunger, he resorts to shoplifting food from a supermarket, rationalising that "[s]ottrarre qualcosa allo spreco organizzato non mi pare un delitto. Al contrario." [pilfering something from the organised waste does not sound like a crime to me. On the contrary] (112). Previsioni del tempo's main characters are equally unusual, if less benevolent. Perhaps the most unsettling is Angelo, an enigmatic character who physically appears only at the very beginning and end of the novel but whose stream of thought saturates the narration. Angelo is a Neapolitan graduate from the Università di Bologna whose early career was defined by his Faustian capacity to ride economic bubbles which, he says, "mi avrebbero portato in alto, dritto dal centro della terra. Angelo dispiega le tue ali" [would bring me up, straight from the centre of the Earth. Angelo spread your wings] (Wu Ming, Previsioni del 
tempo 6). Unlike Angelo, a white-collar criminal, the other two main characters are organised crime's menial labourers. The reader is made to sit in the stuffy, smelly, claustrophobic cabin of an articulated lorry with Antonio, an aging Neapolitan driver, and Giuliano, a cocaine-addicted hardened gangster. In fact, the two uncomfortably fuse into a "solo io narrante" [single narrating I] through which the reader witnesses the journey-from Caserta to Monte Budadda (43). Throughout the narration, the reader is exposed both to the events that happen to the two, and to their train of thought.

\subsubsection{Criminal Midas}

Violence takes on many forms in Previsioni del tempo and its most obvious source is Giuliano, also called "il Conte Piccolo". Wu Ming intruduces him through a murder scene which sets the tone for the character throughout the novel:

Scendendo a lunghe falcate lo sterrato, Giuliano vide il fiume duecento metri sotto, appena velato dalla foschia. Il fuggitivo incespicò. Giuliano gli fu sopra. L'uomo tese le braccia.

L'assassino esplose tre colpi. Il sangue macchiò i vestiti. Giuliano imprecò. Si guardò attorno: era mattina presto, pioveva a dirotto. Trascinò il corpo verso il fiume. Il sangue lasciava una scia, fango fluido, oscuro

[Loping down the dirt road, Giuliano saw the river two hundred meters below, thinly veiled with fog. The fugitive stumbled. Giuliano was on him. The man stretched his arms.

The hitman exploded three shots. Blood stained clothing. Giuliano cursed. He looked around: it was early morning, it was raining heavily. He hauled the body towards the river. The blood left a trail, runny, murky mud] (Wu Ming, Previsioni del tempo 4).

But Giuliano's violence is not confined to a single murderous episode. Far from being a cold-blooded killer, Giuliano's behaviour exudes aggression, 
he is haunted by "ossessioni personali, coltivate con metodo" [methodically cultivated personal obsessions]. To make matters worse, he spends his time sniffing cocaine, and he constantly sips from a bottle of water laced with painkiller to ease the pain that his stomach ulcers cause him (Wu Ming, Previsioni del tempo 9). Drug taking is one of the factors that conspire to exacerbate Giuliano's psychoses. Readers witness his condition worsening throughout the narration until the final homicidal breakdown, when he murders two policemen on leave who had the misfortune of sharing the road with him. After Giuliano's killing spree, Antonio, already on the edge, panics and runs away, leaving Giuliano with the task of driving a lorry full of quartered pigs for the remaining stretch of unpaved mountain road until the rendezvous with Jakup Mahmeti (27).

Whereas Giuliano embodies fast, brutal violence, true criminal power must be found elsewhere. The "Ecomafia 2010" report explains that structures and goals of criminal organisations have recently changed: " $i$ colletti bianchi hanno addirittura scalato i vertici degli stessi clan e guidano, ormai stabilmente, le associazioni a delinquere" [white collars have even obtained top management positions within the clans and lead, now permanently, the criminal organisations] (Osservatorio Ambiente e Legalità, Ecomafia 2010 395). Former Camorra boss Antonio Iovine, nicknamed "'o ninno", was perhaps the most notorious and most powerful white-collar criminal. 'O ninno means "the baby" in Neapolitan dialect, and this reflects both on his boyish facial features and on the fact that he came to criminal power at a very young age, leading the Casalesi clan side by side with Michele Zagaria (Saviano 227). Iovine was finally arrested on 17 November 2010 in Casal di Principe after absconding for 14 years. He was sentenced to the "41-bis" hard prison regime until, on 22 May 2014, he decided to cooperate with the authorities (Del Porto) ${ }^{12}$ Iovine was the Camorra's "ministro dei rifiuti" [ministry of waste] and built his empire upon millions of tonnes of waste which he dumped in thousands of illegal repositories

\footnotetext{
12 The "41-bis" prison regime is designed to prevent communication between the criminal and the external world. It includes bans on the use of telephones, correspondence, meetings, and on other activities normally allowed to inmates ("Modifiche alla legge sull'ordinamento penintenziario e sulla esecuzione delle misure privative e limitative della della libertà ").
} 
nationwide and abroad ("Morire di rifiuti ").

Just like 'o ninno, Angelo belongs to a new generation of white-collar criminals who made the quantum leap from the slums to the globalised world theatre:

Sopra, in superficie, i fratelli spadroneggiavano, ma in un cortile ridicolo, miserabile. Una piazza di studenti e di tossici, e poche vie circostanti, in una città dove la strada non contava un cazzo. Facevano i grossi, mentre passavano di moda, entravano in scadenza, non si accorgevano che nuovi lupi cominciavano a scendere da montagne a loro ignote [Above, on the surface, the brotherhood domineered, but in a ridiculous, wretched backyard. A square full of students and junkies and a few surrounding streets, in a city where streets are worth sod all. They swaggered while they went out of fashion, they passed their expiry date, they did not realise that new wolves were starting to descend from mountains they did not know] (Wu Ming, Previsioni del tempo 6).

Angelo's thoughts offer an intimate point of view to understand the criminal mind and sketch a possible psychology of this new class of criminals. Angelo understands he is part of a criminal elite and thinks of his subjects disparagingly: Antonio is a "fidato povero cristo" [trusted poor devil], the ruthless Giuliano is a "buzzurro" [boor]. Although he belongs to the Camorra's middle management, Angelo belongs to the same class of white-collar criminals as 'o ninno, who prefer to delegate violent crime and direct their trafficking from the safety of their hideouts: "Io ho il denaro. Ne posseggo il senso, ne capisco la natura. Lo invento. Le armi sono per i buzzurri" [I have money. I have a sense for it, I understand its nature. I invent it. Weapons are for boors] (Wu Ming, Previsioni del tempo 5). Angelo's disdain for Giuliano comes from his understanding that violent criminals have become the last rung of the ladder of power. Angelo does not need to dirty his hands with blood but this does not mean that he is any less dangerous: his power comes precisely from his perceived respectability. 
Roman historian Suetonius reported that Titus, son of the Roman emperor Vespasian complained about the disgusting nature of a new tax on the sale of urine from public urinals, which was used in industrial processes. In response to this a remark, Vespasian drew a gold coin and asked his son whether it stank. At Titus' negative answer, he replied "Atqui ... e lotio est" [And yet it comes from urine] (Suetonius 23.1). Hence the Latin proverb "Pecunia non olet" [Money does not stink]. As Angelo remarks, his power is manipulating money, and to money many respond without questioning its provenance. This enables Angelo and other white-collar criminals to operate in close contact with legal business and offer rates which undercut legitimate disposal companies:

La cosa migliore sono le facce quando gli mostro i miei prospetti, e confrontiamo tabelle e tariffe. Quello che gli costa dieci con me scende a due, quello che gli costa quattro io glielo PAGO uno.

Pulito. Ditte, bolle, documenti, certificati. L'iniziale increspatura sul volto, perplessa e interrogativa, che via via si distende come una camicia sotto il ferro da stiro. Fino a sciogliersi in un sorriso fraterno.

[The best thing are the faces when I show them my prospectuses, and we compare tables and rates. That which costs them ten with me comes down to two. That which costs them four, I PAY them one.

All clean. Firms, bills, documents, certificates. The initial perplexed and interrogative wrinkle on the face which gradually smooths out like a shirt under the iron. Until it melts into a brotherly smile] (Wu Ming, Previsioni del tempo 14).

Such mechanisms allow the Camorra to infiltrate and work side by side with legitimate business, but their profits come at the expense of the environment and society.

"E noi appena tocchiamo la monnezza la facciamo diventare oro" [And whenever we touch rubbish, we turn it into gold], boasted a waste trafficker under police surveillance (Saviano 321). Criminal culture, which often associates gold with trash, seems to have understood something that the consumerist 
culture that produces such trash has been unable to grasp. Angelo, too, seems to be vividly aware of the value of trash. "Il Conte", Giuliano's elder brother, attracts Angelo's scorn because of his gross language and decadent lifestyle. However, it is through Il Conte's words that Angelo undergoes an epiphany which allows him to understands the real value of trash:

Tu manco lo immagini, [Il Conte] aveva detto, la monnezza è oro.

Angelo si rese conto che tutto quello che lo attorniava, tutti gli oggetti di cui era fatto il mondo erano accomunati da un destino piano, univoco, ineluttabile. Si stava per divenire rifiuti. Ma quello poteva non essere l'esito finale.

La monnezza è oro, aveva detto Il Conte.

["You can't even imagine it," [Il Conte] had said, "rubbish is gold." Angelo realised that everything around him, every one of the objects the world was made of shared the same plain, univocal, ineluctable. They were about to become trash. But that might not be the final outcome. "Rubbish is gold," Il Conte had said. (Wu Ming, Previsioni del tempo 3 )

Wu Ming place on Il Conte's lips the words of boss Nunzio Perrella, "La monnezza è oro" [Rubbish is gold], but this is just one instance of the equation between trash and gold: throughout the novel, Wu Ming use the word "oro" [gold] as a metaphor for trash. "Olii, solventi, vernici. Rifiuti speciali, ospedalieri, della catena agroalimentare. Scarti dell'edilizia, laterizi, i più ambiti. Oro" [Oils, thinners, paints. Special waste, hospital waste, waste of the agri-food chain. Discards from the building industry, brickworking, the most coveted. Gold] (Wu Ming 2, Guerra agli umani 14). For Angelo, waste is "[a]nother gold rush for new kids on the block" (24) $\left.\right|^{13}$ The lands where waste is disposed of are, "terre di latte e miele, dal ventre rigonfio d'oro. Oro che aumenta l'incidenza del cancro, la mortalità infantile, le leucemie" [lands of milk and honey, their belly

\footnotetext{
${ }^{13}$ English in the original.
} 
bulging with gold. Gold which increases the incidence of cancer, infant mortality, leukaemia] (41).

If pursuit of profit unbridled by moral concerns is the driver of crime then, Wu Ming 2 argues, crime is not different from unregulated capitalism:

Previsioni del tempo cerca di passare l'idea che in fondo il capitalismo perfetto diviene mafia, cioè che l'impresa capitalistica criminale è per certi aspetti l'impresa capitalista perfetta, in cui non ci sono sindacati né una controparte dei lavoratori, tutto trova il suo posto senza particolari problemi etici e in fondo tutto può avvenire dietro le quinte del denaro che fa da grande sipario [Previsioni del tempo tries to convey the idea that, at the end, perfect capitalism becomes mafia. That is, the capitalist criminal entreprise is, from certain points of view, the perfect capitalist enterprise, where there are no unions or a worker's counterpart, everything takes place without any ethical qualms and, at the end, everything can happen behind the scenes of money which acts as a great curtain] (Appendix C “Intervista a Wu Ming 2").

In this system, the weak lose, workers lose, citizens lose, the environment loses. However, Wu Ming's narrative shows that even the so-called winners-the criminals and the powerful —will be left, in the long run, with little to celebrate.

\section{A Global Junk-Yard}

Gold is trash and trash is gold. Just like King Midas, camorristi change matter into gold, but, like King Midas, this is a gift that they soon begin to regret:

Maeonius, pulchro cum verteret omnia tactu;

sed postquam riguisse dapes fulvamque revinctos

in glaciem vidit latices, tum munus acerbum

sensit et inviso votum damnavit in auro.

[So Midas, king of Lydia, swelled at first with pride when he found he could transform everything he touched to gold: but when he 
beheld his food grow rigid and his drink harden into golden ice then he understood that this gift was a bane and in his loathing for gold cursed his prayer] (Claudianus 1.2.177-180).

As we have seen previously, this failure to project and attach importance to future well-being is true of criminals both in the novel and in reality. Boss Carmine Schiavone appears in his confessions to be well aware of the consequences of his activities on his native lands: "gli abitanti del paese rischiano di morire tutti di cancro entro venti anni; non credo, infatti, che si salveranno: gli abitanti di paesi come Casapesenna, Casal di Principe, Castel Volturno e cosi via avranno forse venti anni di vita!" [the inhabitants of the town run the risk of dying of cancer within twenty years. I do not believe, in fact, that they will save themselves: the inhabitants of towns such as Casapesenna, Casal di Principe, Castel Volturno and so on will maybe live for twenty more years!] (Scalia 12). Notwithstanding this, he chose to proceed with the business of dumping toxic waste in the lands around Casal di Principe and transformed campania felix from fertile agricultural lands to the contaminated landfill of Italy.

Angelo would probably include Carmine Schiavone in his definition of "buzzurro", a tag that Angelo likes to repeat and that defines the oldfashioned criminal who, like Giuliano, pursues a violent career because of short-sightedness and lack of finesse. It also defines the Neapolitan camorristi who, because of short-sighted greed, have irretrievably poisoned their own backyard: "fino a ieri gran parte della merda finiva a casa mia. Ai buzzurri interessano i soldi, non la salute dei loro figli buzzurri" [until yesterday, most of the shit ended up at my home. Boors are interested in money, not in the health of their boorish children], he quips, before expressing frustration at Neapolitans failing to understand that burying toxins in their own countryside would have bad consequences (Wu Ming, Previsioni del tempo 24). Neapolitans, he continues, "[r]icordano le mie litanie su quanto eravamo arretrati. Ricordano considerazioni velenose sui veleni che non gli avrebbero fatto godere il denaro che accumulavano" [remember my string of complaints about how backwards we were. They remember toxic considerations about the toxins that will not let 
them enjoy the money they accumulated]. But Neapolitan criminal leaders were too close-minded to find alternatives:

C'era sarcasmo nelle loro voci buzzurre: "A cchi 'a vulissi rà sta'mmerda?" Gli bastavano e avanzavano i soldi pubblici, l'emergenza continua, i posti di lavoro, le cooperative, gli sghei degli imprenditori del nord. Tutto sotto il tappeto di casa. Oro dentro le tasche, cianuro sotto le scarpe. Chi se ne fotte [There was sarcasm in their boorish voices: "Who do you want to give this shit to?" The public money, the continuous state of emergency, the jobs, the cooperatives, the dosh of the Northern entrepreneurs were more than enough for them. Everything under the carpet at home. Gold in the pockets, cyanide under the shoes. Who gives a fuck] (Wu Ming, Previsioni del tempo 24).

The activities of Camorra's buzzurri have sentenced the land of fire to sterility, but international readers should avoid believing that this problem is strictly Italian. Stacy Alaimo describes in her Bodily Natures the porous borders of the body, but nation-states are not tight containers, either. The nature of globalisation promotes the circulation of goods and people internationally. While this phenomenon allows consumers to purchase out-of-season groceries from Ghana, Korean cars and cheap clothes made in Bangladesh, it favours the spread of invasive species, pathogens as well as toxins. And in fact, it was not long before the Camorra realised that it would be profitable to seal allegiances with foreign criminal powers and ship the toxic waste abroad to countries with weak environmental legislation. The Ecomafia reports document a dizzying scenario of how thousands of tonnes of waste, mostly metal scraps and plastics, moves through the country and then on to a number of international destinations. Exports of waste "sembrano seguire (poco misteriosi) percorsi elusivi, spostandosi verso porti italiani e stranieri ritenuti, a torto o a ragione, meno 'attenti'" [appear to follow (hardly mystifying) elusive tracks, moving towards Italian and foreign ports which are deemed, correctly or not, less 'attentive'] (Ecomafia 2012 101). The 2012 edition of the Ecomafia report shows that 
by far the most important destination for irregular shipping of waste was the People's Republic of China (PRC), and that the situation had stood for several years. In 2011 only, more than 7,000 tonnes of waste were seized before being shipped to the PRC (99-100). Similarly, Saviano mentions international waste trafficking in Gomorra: "gli stakeholder campani spesso utilizzano le strade del narcotraffico che i clan mettono a disposizione per trovare nuovi territori da scavare, nuove tombe da riempire" [the Campanian stakeholders often used the roads of drug trafficking that the clans offer to find new lands to dig up, new tombs to fill] in places like Romania, Albania, Mozambique or Somalia where the clans can count on acquaintances and supporters. (Saviano 324). Franco the stakeholder's best students are Chinese: the expertise of Italian waste traffickers is rapidly spreading abroad. The town of Guiyu in particular has become the hub for the disposal of electronic waste, with appalling environmental consequences: there, "le falde acquifere sono completamente compromesse, al punto da essere costretti a importare dalle province vicine l'acqua potabile" [aquifers are totally compromised, to the point of having to import drinking water from neighbouring provinces] (321). More than 80 percent of children in Guiyu suffers from elevated blood lead levels (Monbiot,"Toxic Assets"; Huo et al. 1116). However, Guiyu is hardly a unique case of extreme pollution. Agbogbloshie, in Ghana, is also a digital dumping ground where millions of tonnes of waste are processed in disregard of all safety precautions, leading to elevated level of contaminants such as antimony, lead and arsenic in the workers' urine (Asante et al. 72 ).

International waste trafficking is an important theme in Previsioni del tempo. Angelo's alternative to burying the toxic waste in the "land of fires" is to ship it to international destinations like Romania, which he defines "[i]l nostro confine col Messico" [our border with Mexico], or the People's Republic of China, "il grande ruminante del capitale" [the great ruminant of capital] (Wu Ming, Previsioni del tempo 24, 14). The People's Republic of China, in particular, seems to be a favourite destination for Angelo's trafficking. In Previsioni del tempo, Angelo, again, illustrates the mechanics of waste trafficking and describes the 
frightening pace of development of the developing Asian nation:

La Cina compra tutto, chiede tutto, vuole tutto. Ingurgita qualsiasi cosa, digerisce, fa scomparire. Moltiplica. Ogni momento interi grattacieli finanziari si edificano come dal nulla. Architetture giganti fatte di numeri, chip, flussi di materia prima, carne umana, territori mutanti [China buy everything, asks for everything, wants everything. It gobbles all, digests, wipes out. Multiplies. Each instant, whole financial skyscrapers are built as if from thin air. Giant architectures made of numbers, chips, fluxes of raw materials, human flesh, mutant territories.

Angelo understands that a similar rate of economic growth is not sustainable and that China will end up consuming itself in its industrial frenzy: China, he claims, will last "vent'anni, più o meno" [twenty years, more or less] However, this premonition fails to worry him. Just as the United States are a declining empire, someone else will replace China when the time comes, "i marziani, forse ... nessuno fa progetti a così lungo termine oggi" [Martians, perhaps ... no-one makes such long-term plans nowadays] (Wu Ming, Previsioni del tempo 14). It is interesting to notice that Angelo appears on the surface to understand that money cannot shield him from the consequences of terminally polluting one's backyard with dangerous toxins. However, like many others, he operates on shaky ethical grounds and with time-frames so short that they prevent him from considering the long-term consequences of his dirty business. It does not matter how far away dangerous toxins are buried if their lifetime is virtually infinite: heavy metals and dioxins easily find their way into the food chain and then biomagnificate until they reach potentially toxic concentrations in animals which humans ultimately consume.

In Previsioni del tempo, $\mathrm{Wu}$ Ming attempt to sketch the white-collar criminal mind by introducing Angelo, a waste dealer who is one of the few (shortterm) winners in the criminal economy. Contrary to the popular depiction of the criminal, Angelo is not a blood-thirsty killer: instead he is a snobbish and educated technician. By creating such an unusual character, Wu Ming contribute 
to the awareness that, although criminal organisations have modified their strategy, the danger they pose for humans and ecosystems alike is still enormous. Albeit fictional, Wu Ming's novel sheds light on the workings of the criminal business and its success, and ultimately on the big picture of the ciclo dei rifiuti in Italy. The psychological dimension of the phenomenon is just as important as its physical dimension, and equally worthy of analysis. Wu Ming's attempt at detailing the daily life of the labourers of waste disposal shows the deep changes that criminal organisations have undergone in the last 20 years. Their metamorphosis has been radical and has allowed the mafias to make use of globalisation to diversify and multiply their sources of income. Criminal cartels have now become more businesslike, and have invaded grey areas such as waste disposal and building, a "normalisation" of crime.

\section{Criminal Business Practices}

Although Angelo only appears at the beginning and at the end of the narrative, his presence haunts the narration, contributing his ruthless, but refined and lucid thinking which sheds light on the mechanisms that organised crime employs in order to profit from waste. In his naïveté, Giuliano is baffled at the apparently meaningless need to bring more waste to Naples, a city already drowning in it: "Giuliano si era chiesto ancora una volta perché diavolo fosse necessario andare a prendersela su al nord, la monnezza, che ce n'era più che abbastanza lì da loro" [Giuliano asked himself once again why the hell it was necessary to go to the North to collect the rubbish, while there was more than enough of it there where they lived] (Wu Ming, Previsioni del tempo 42). Waste follows routes which appear irrational to those unfamiliar with the mechanisms which the Camorra employs to avoid detection and to magically turn trash into gold. One such mechanism is the "giro di bolla" [change of bill] scam, where waste travels

solo cartolarmente da uno stoccaggio all'altro, oppure attraverso impianti di recupero e/o di compostaggio con il fine di declassare la tipologia del rifiuto trattato e aggirare le normative. Attraverso 
una rete articolata di faccendieri, analisti, chimici, impiegati e trasportatori il rifiuto entra con la bolla del produttore e con un determinato codice Cer in un centro di stoccaggio [only on paper from one storage facility to another, or through recycling and/or composting plants, so as to downgrade the typology of the waste concerned and bypass the law. Through a complex network of fixers, analysts, chemists, employees and carriers, the waste enters with the producer's note and a certain EWC code in a storage centre] $!_{4}^{14}$

Through this mechanism, only a small fraction of dangerous waste is actually shipped to the treatment plants, the rest is mixed with inert detritus, labelled as harmless, and disposed of in unprotected landfills or worse, mixed with compost and soil to be used in agriculture. Angelo explains the "giro di bolla" scam with an immediacy which Legambiente's report "Rifiuti S.p.A." probably cannot afford:

Rendo i veleni omeopatici. Cocktail ben dosati di scarti industriali, polveri, olii residuali, amalgamati dentro i rifiuti dell'edilizia. Le bolle rimangono autentiche. Camion semivuoti viaggiano verso siti di smaltimento dove non sosterranno costi che verranno rimborsati. Container pieni che vanno dritti verso l'esofago che li inghiottirà in pochi minuti. Finiranno in un pilone, una tangenziale, una collinetta artificiale dove prima correva il Fiume Giallo [I make poisons homeopathic. Well-measured cocktails of industrial residues, dusts, residual oils, amalgamated in the building waste. Bills remain authentic. Half-empty trucks travel towards disposal sites where they will not sustain costs that will be reimbursed. Full containers go straight towards the oesophagus which will swallow them in a few minutes. They will end up in a pylon, a ring road, an artificial hill

\footnotetext{
${ }^{14}$ Cer: Catalogo europeo dei rifiuti [EWC: European Waste Catalogue]. The EWC is a list of codes which identifies each class of waste and defines the best practices in handling, stocking and treating them. It assigns a 6-digit number to each type of waste and is commonly found in the Waste Transfer Notes, a document which accompanies shipments of waste from the producer into the stocking facility (Osservatorio Ambiente e Legalità, Ecomafia 2005|34) .
} 
where the Yellow River used to course] (Wu Ming, Previsioni del tempo 24).

Environmental reports often have scant impact on the public because they are perceived as material aimed at insiders and specialists. This distance favours criminal organisations, who keep their activities away from the limelight relying on apathy and ignorance to minimise opposition to their dirty practices. However, environmental degradation affects everybody because everybody needs food, water and air to survive. Involvement begins with understanding the real issues of our time and becoming literate in ecological matters which affect society. Previsioni del tempo contributes to raising ecological literacy by approaching readers with skilful metaphors which allow them to explore the complex business mechanisms that enable ecomafia, while avoiding the intimidating language of specialistic reports.

\subsubsection{A Landscape of the Mind}

Previsioni del tempo means "weather forecasts" in Italian, thus hinting at the fact that the rain plays a fundamental role in the symbology of Wu Ming's novel. In Previsioni del tempo, a pouring rain gives Antonio and Giuliano no quarter from the beginning of the novel. The rain provides a bleak and depressing backdrop to Antonio and Giuliano's journey. Moreover, it negates any respite from the claustrophobic enclosure of the lorry's cabin where Antonio and Giuliano are confined: "le cateratte del cielo si erano aperte ancora di più, un metro di cataratta a est e uno a ovest, veniva giù un inferno liquido, oleoso, il vetro davanti era sporchissimo, il tergicristallo non contava quasi, Antonio intuiva la strada più che vederla" [the cataracts of the sky were open even wider, a metre of cataract to the east and one to the west. A liquid, oily hell was pouring, the windscreen in front was very dirty, the wiper was almost useless. Antonio guessed the road more than seeing it] (Wu Ming, Previsioni del tempo 20). The two travellers are confined in the smelly cabin of the lorry but rain is one of the several elements contributing to their discomfort: to paraphrase Wiston 
Churchill's famous quote about Russia, they are stuck in a snare wrapped in a tangle, inside a trap; with no key. As the rain lashes on the lorry, the two men travel the Italian peninsula on the A1 motorway, South to North, their world relegated to the few square meters of the cabin 15 Marc Augé's definition of "nonplaces" includes "[ $t$ ]he installations needed for the accelerated circulation of passengers and goods" (34). Antonio, bound together with Giuliano, drives his lorry through a non-place while the pouring rain prevents even his senses from escaping the oppression. Even though the two eventually leave the motorway and enter the Apennines south of Bologna, they are still denied access to reality. In fact the reader is able to follow the route of the lorry on a map throughout the first leg of their journey: "Caserta, Capua, Caianiello", Viterbo, and then Siena, Firenze Sud and Roncobilaccio (Wu Ming, Previsioni del tempo 9-13). However, as the lorry exits the $\mathrm{A} 1, \mathrm{Wu}$ Ming provides the last recognisable hint as to the location of the two: "la strada passava cinquecento metri sotto il casello di Pian del Voglio" [the road passed five hundred metres under the Pian del Voglio toll] (20) ${ }^{16}$ This landmark informs the reader that the two are now travelling on the "La Futa" and have thus abandoned the motorway ${ }^{17}$ The two inhabitants of the lorry's cabin abandon the non-place of the motorway but, instead of being greeted by familiar surroundings, they enter a new, alien world of imaginary place-names: "Zonca di Sopra”, "Pieve Dei Pini", “Monte Budadda" (19, 22, 25). None of these locations exist around Bologna or, for that matter, anywhere else in Italy: unable to rely on familiar place names, the reader feels lost. The surreal place names, and the torrential rain preventing the reader from glimpsing any feature of the landscape create a micro-environment which highlights the dysfunctional relationship between the two occupiers of the cabin: on the one hand, the neurotic, volatile, and cocaine-addicted Giuliano, and on the other hand, Antonio, mortally afraid of his companion.

\footnotetext{
15 The A1, or "Autostrada del Sole" [Sun's Motorway] is the longest motorway in Italy, built in 1964 and connecting (among other cities) Milan, Bologna, Florence, Rome and Naples.

${ }^{16}$ Pian del Voglio is a small village $30 \mathrm{~km}$ south of Bologna.

${ }^{17}$ La Futa is an alternative name for SR65, a road which connects Bologna and Firenze through the "Futa" mountain pass.
} 
Only animal fear shakes Antonio from his fate. When he hears Giuliano's gun shooting, he decides to run: "c'era qualcosa di più importante di tutte le imprese del mondo. L'impresa numero uno, morire nel proprio letto, né in galera, né morto ammazzato ... Istinto" [there was something more important than all the feats in the world. The number one feat: dying in your own bed, neither in jail or murdered ... Instinct] And thus, instinct appears to be the force that allows Antonio to break free from his captivity. As Antonio runs for his life in the woods, the rain continues to fall, but the landscape changes subtly. Wilderness and elements cease to be monotonous and contaminating, and become alive and soothing: "L'odore del bosco era familiare, confortante ... La pioggia scendeva meno fitta, le fronde riparavano" [The smell of the woodland was familiar, comforting ... Rain fell less heavily, the foliage sheltered] (Wu Ming, Previsioni del tempo 28). Antonio discovers that the natural world still commands respect, but at least it offers freedom and an opportunity for redemption. Antonio's encounters with the local wildlife scare him, but he reflects that humans are more dangerous than beasts:

Le mosse dei cinghiali non erano prevedibili, quelle del Conte Piccolo sì, almeno a grandi linee: forse avrebbe deciso di andare all'appuntamento, forse avrebbe deciso di seguirlo e di fargliela pagare, cose brutte, cose che aveva sentito dire, e ne sarebbe uscito conciato peggio che dall'incontro con il grosso verro che grattava la schiena contro il tronco, pochi istanti prima. Antonio deglutì. In realtà non c'era altra strada che proseguire, e che dio la ce la mandi buona [The boars' movements were not predictable, those of the Conte Piccolo were, at least broadly. Perhaps he would decide to go to the rendezvous, perhaps he would decide to follow him and make him pay. Ugly stuff, stuff he heard about, and he would come out of it worse than from the encounter with the huge boar which was scratching its back against the log a few moments ago. Antonio gulped. In reality he could do nothing but advance, and may god help us] (Wu Ming, Previsioni del tempo 32). 
Antonio's act of rebellion against his criminal overlords redeems him from captivity, and wilderness offers him shelter and hope. From the bleak, colourless claustrophobia of the lorry's cabin, Antonio finds himself in dangerous, yet beautiful and exhilarating surroundings which smell of freedom and hope.

\section{The Third Circle (of Waste)}

The combination of soggy weather and sense of loss in Previsioni del tempo reminds the reader of certain passages of the Divina commedia. An eternal rain lashes the gluttons in Dante's Inferno as they lie naked in fœtid sludge:

Io sono al terzo cerchio, de la piova

etterna, maladetta, fredda e greve;

regola e qualità mai non l'è nova.

Grandine grossa, acqua tinta e neve

per l'aere tenebroso si riversa;

pute la terra che questo riceve.

[I am in the third circle of the eternal, accursed, cold and heavy rain: its measure and its quality are never new; huge hail, foul water, and snow pour down through the murky air; the ground which receives it stinks] (Inferno, VI, 7-12) ${ }^{18}$

The penance Dante imposes on gluttons is, as the law of contrappasso imposes, a direct emanation of their own lack of self-restraint: just as they were unable to control their animal appetites when alive, they are damned to wallow like animals in muck after death. As in life they sought the most flavoursome food, in death they have to endure the stench of the Third Circle. They used to sit comfortably in their warm homes enjoying banquets during their mortal existence and now they are made to lie naked in the mud, while freezing rain and hail lash them.

Just like Dante Alighieri's damned, Antonio and Giuliano are trapped in a hell of their own, unable to perceive anything outside of their suffering: "la

\footnotetext{
${ }^{18}$ Translation from The Divine Comedy. Inferno: Text and Commentary by Charles S. Singleton.
} 
pioggia era un muro, talmente fitta da assumere un colore proprio, e questo colore era il nero" [rain was a wall, so heavy as to take a colour of its own, and that colour was black] (Wu Ming, Previsioni del tempo 12). Whereas rain traditionally represents purity and fertility, Dante's infernal precipitations are tainted and contaminated. Likewise, in Previsioni del tempo, rain accumulates all the detritus of consumerism:

L'acqua batteva la strada, i tetti e i cofani delle macchine, sollevava schizzi, impregnava la massa di rifiuti ammassata attorno e sopra tre cassonetti stracolmi, colava oleosa sull'asfalto, bolliva d'una specie di schiuma bianca, bolle e bollicine come segni di malattia infettiva, come spuma marina [The water lashed the street, the roofs, the hoods of the cars, sprayed, saturated the mass of trash amassed around and over three overfilled skips. It dripped oilily on the asphalt, it foamed with a kind of white scum, bubbles and froth like symptoms of an infectious disease, like sea surf] (Previsioni del tempo 7).

As in the Third Circle, bad weather is not just an annoying meteorological event: whereas the rain in Previsioni del tempo appears to be of a more profane nature, meteoropathy particularly affects Antonio and Giuliano, exacerbating their obsessions and neuroses. The weather and the two men's mood appear to be deeply related and whenever the tension rises in the cabin of the lorry, the weather seems to worsen, aggravating their suffering:

tutto schizzava, acqua e gas esausti, percolato atmosferico e spurghi di camion, olio e bestemmie di automobilisti. Antonio non si era aspettato un viaggio tranquillo. Ora le cose prendevano una brutta piega, il Conte Piccolo era una molla compressa, non si vedeva un cazzo, e poi, altro che file sulla Firenze-Bologna: il Conte Piccolo aveva detto che si doveva uscire, fare la strada normale, inerpicarsi sulla Futa, chissà che cosa avrebbero trovato lassù, ora grandinava addirittura, che cazzo, chicchi grossi come acini d'uva, sporchi, angolosi [everything sprayed, water and exhaust gases, atmospheric 
percolate and truck discharges, oil and drivers' curses. Antonio was not expecting a peaceful journey. Now things took a turn for the worse, Il Conte Piccolo was on the edge, you couldn't see shit, and then, forget the queues on the Firenze-Bologna motorway. Il Conte Piccolo said that they had to go out, travel on the normal road, climb the Futa, who knows what they'd find there. Now it was even hailing, what the fuck, hailstones as big as grapes, dirty, jagged] (Wu Ming, Previsioni del tempo 13).

Just like souls in hell, Previsioni del tempo's characters are overseen by unstoppable forces. Cerberus, the mythical three-headed dog guards Dante's Third Circle. It pummels and dismembers the unfortunate souls who approach it. Notwithstanding its uncontrollable rage, Virgil only needs to feed the demon with mud to appease it so that it will let Dante continue his quest (Inferno, VI, 13-18, 22-27). Analogously, when describing China, Wu Ming describe its appetite for matter and its hysterical destructiveness:

Il grande ruminante chiede tutto, digerisce tutto. Sbanca montagne, spiana colline, allaga valli, costruisce dighe, città, porti. Compra tutta la terra, tutti gli scarti del mondo. Mangia merda e caca oro. Non si cura di cosa sia fatto l'impasto, troppo vorace [The great ruminant asks for everything, digests everything. It razes mountains, flattens hills, widens valleys, builds dams, cities, ports. Buys all the land, all the discards of the world. Eats shit and shits gold. It doesn't care what the mixure is made of: it is too ravenous] (Wu Ming, Previsioni del tempo 14).

China, the great ruminant, ravenously devours raw materials and detritus, restlessly builds and razes. It insatiably feeds on the waste that developed countries throw back at it while at the same time feeding the rich nations with the throwaways they need to satisfy their whim, in a vicious equation of furious consumption and waste. Wu Ming's Previsioni del tempo associates consumerism with spiritual and psychological misery. Dante's gluttons were sentenced to hell 
because of their incontinence: modern consumers are likewise unable to contain their desire for the products of industry. The result is analogous: a tedious, mindless existence drowned in the toxic legacy of dissoluteness.

Wu Ming 2 explains that "in un sistema capitalistico perfettamente dispiegato, lo sfruttamento dell'uomo sull'uomo anche non evidente o diretto è comunque talmente elevato che è inevitabile che tutti coloro che partecipano a quell'impresa siano persone con dei disturbi di natura neurologica" [in a perfectly deployed capitalist system, the exploitation of humans by humans, even though it may not be direct or evident, is nonetheless so prominent that all those who participate in such enterprise are neurologically disturbed people] (Appendix C “Intervista a Wu Ming 2"). Pure capitalism encourages the exploitation of the workforce and of the natural world and it possesses no intrinsic safeguard against the unsustainable overuse of limited resources. As Wu Ming 5 observes, the production of useless products is intrinsically connected with capitalism because capitalism does not aim at satisfying human needs but at consumption per se (Wu Ming 5, "'Non c'è un modo 'giusto' di produrre oggetti inutili' '). Previsioni del tempo, just like Gomorra, demonstrates how organised crime carries the guiding principles of the free market to their logical, merciless, extremes, bringing suffering to all including its collaborators. Although someone may consider this outcome as a sort of poetic justice, Previsioni del tempo, providing one oblique gaze on the Camorra's menial workers' day, reveals the extensive grey areas where it is almost impossible to separate organised crime and legitimate business. In fact, business is just the most direct way through which organised crime infiltrates society. Consumerist practices produce the raw material that enriches the ecomafias: waste. As Antonio and Giuliano travel, the falling dirty rain soaks the landscape and contaminates everything, a direct reference to the penance of the gluttons in the Divina commedia. This is a deliberate yet disguised suggestion: Italians are as much victims as accomplices to ecomafia. It is true that the narration focuses on the two tortured characters of Giuliano and Antonio. However, the rain which falls on Antonio and Giuliano also falls on "buona parte della penisola" [great 
part of the peninsula] thus suggesting that the two couriers share their penance, and thus their sin, with most Italians (Wu Ming, Previsioni del tempo 6).

However, there is a fundamental difference between Dante's damned and the characters populating Wu Ming's novel. In Dante's hell, souls have abandoned all hope and will be forever trapped in their circle, whereas the characters of Previsioni del tempo can still be redeemed. Antonio's escape from his lorry is an epic moment in Previsioni del tempo: facing the exhilarating uncertainty of the wilderness on the one hand and the certainty of murderous madness on the other, Antonio becomes an unlikely hero who defies the violence of the Camorra to regain his freedom and his humanity.

\subsection{Conclusion}

Gomorra, Delta blues and Previsioni del tempo draw a progression from the explicit to the metaphorical, which highlights the mechanisms through which organisations profit from the destruction of the land and the death of its inhabitants. As we have seen in "Terra dei fuochi", Saviano blurs the line between what is real and what is fiction. Saviano-author is real, but Savianonarrator is, to all effects, fictional. We just cannot know whether a stakeholder named Franco really lectured Roberto Saviano about the supposed positive contribution of illegal waste disposal to the national economy. We do know that some of the characters who populate Gomorra are undeniably all-too-real: for instance "Sandokan" Schiavone and "Cicciott' 'e Mezzanotte" Bidognetti are well-known Camorra bosses currently under police custody (Saviano 67). On the other hand, Kai Zen's fictitious characters in Delta blues inhabit a landscape which is unmistakably the Niger Delta. Unlike Carmine Schiavone and his cousin "Sandokan", Tamerlano and Klein never existed as flesh and blood humans: they are points of view through which readers can experience a far away place which their choices as consumers affect profoundly. It is also true that, unlike Roberto Saviano, who was born and lived in Naples, none of the Kai Zen ever visited Nigeria (Appendix A “Intervista a Jadel Andreetto"). 
Nonetheless, the place they describe is immediately recognisable as the Niger Delta with its forests, its people and its petroleum spills. Previsioni del tempo's characters, just like the ones in Delta blues, are all fictional. However, unlike Delta blues' Tamerlano, after Previsioni del tempo's lorry exits the motorway and enters Emilia Romagna, it crosses the border of real geography and finds itself in an alternative, hellish Italy where the readers have to rely completely on Giuliano's unreliable guidance.

Each of these three literary works follows a different recipe to contaminate reality with imagination. Notwithstanding the differences, it is clear that, by hybridising genres, authors employ fictional stories and characters as literary devices that highlight the mechanisms and the consequences of extreme capitalist practices. In particular, they guide their readers through toxic places that bear the scars of industrialism: the Land of Fires, the oil-producing Niger Delta and the A1 motorway in Italy. By being guided through these contaminated landscapes, readers understand the nature of the forces which contribute to create them: reckless greed, short-termism and the disconnection between powers whose aim is to accumulate wealth and the health of land. Moreover, talking about the land allows the writers to tell stories about the suffering of the people who inhabit and depend on the land, such as Neapolitan farmers and Ogoni fishermen, as well as the stories of those who work for the organisations responsible for the destruction: Franco the "stakeholder", Antonio, Angelo and Giuliano. Finally, it is important to notice that the three works, through different pathways, eventually come to the same conclusion or, at least, to the same question. Where does the ultimate responsibility lie for industrial practices aimed at maximising revenues and material output while discharging their dangerous by-products into the environment? In my view, the authors of Gomorra, Delta blues and Previsioni del tempo decline to directly apportion blame. Instead, they let their stories and characters speak for themselves, while encouraging the emergence of inconvenient questions and inviting readers to face moral dilemmas intrinsic to a Western industrial lifestyle. 


\section{Chapter 4}

\section{Locality 2: Changes in Land Use}

This chapter explores the topic of land use change in Italian twenty-first century literature. Its introductory section clarifies the meaning of the expression "land use change" and briefly sketches a history of land use change through literature (and cinema). The following sections focus on the literary representation of illegal building, urbanisation and organised crime's "ciclo del cemento" [cycle of cement] in three twenty-first century Italian books. The first is Simona Vinci's novel Rovina, published in 2007 in the VerdeNero series; the second is Fuoco! (2007), Giancarlo De Cataldo's foray into ecomafia narrative published in the same series; and the third is Roberto Saviano's Gomorra, also discussed in the previous chapter, which describes how the Camorra controls and profits from the cycle of cement.

\subsection{A Look at Our Changing Landscapes}

Rockström et al. suggest that no more than 15 per cent of the total global land surface should become anthropised, including "the conversion of natural ecosystems into agriculture or into urban areas; changes in frequency, duration or magnitude of wildfires and similar disturbances; and the introduction of new species into land and freshwater environments" (473-474). The study estimates that 11.7 per cent of total global land surface is currently being 
exploited for human needs, so land use still appears to be within the boundaries of sustainability. However, future and present known-unknowns intrinsic in this estimate pose challenges to the conservation of pristine ecosystems. First, the characteristics of land use matter more than the mere percentage of land use purposed to satisfy human needs. Steve Bass, Senior Fellow at the International Institute for Environment and Development, agrees on the whole with Rockström's call for further investigation about the boundaries of human influence on the global ecosystem, but also points out the uncertainties in Rockström's approach. The land use change boundary, Bass argues, is based on a "sensible - though apparently arbitrary-expansion factor", and this means that the 15 per cent land use change boundary could really be 20 per cent or, indeed, 10 per cent. Bass concludes that "sustainability of land use depends less on percentages and more on other factors. For example, the environmental impact of 15 per cent coverage by intensively farmed cropland in large blocks will be significantly different from that of 15 per cent of land farmed in more sustainable ways, integrated into the landscape" (114). The second knownunknown is population. UN medium-fertility projections estimate a world population exceeding 10 billion by the end of this century, but the error bars of the report are huge. In contrast with to the 6.7 billion low-fertility scenario lies the possibility that Earth will host 16.6 billion in high-fertility projections ("World Population Prospects, the 2012 Revision"). Increased world population would place even greater pressure on ecosystems to provide food, water, fuel and building materials. Developing countries such as China and India are rapidly industrialising. Their increasingly affluent populations can afford more volitional consumption, leading to increases in mining and manufacturing as well as the adoption of a Westernised diet rich in fats and animal protein. Several studies confirm that animal-based diets require dramatically more water, land and energy per unit of nutrition compared with plant-based diets (Baroni et al.; D. Pimentel and M. Pimentel). The cultivation of soya to be turned into animal feed is one of the leading causes of deforestation, the other is the cultivation of palm oil, a fat commonly used in processed food. Margono et al. report a 
loss of 0.84 Mha (million hectares) of primary forest cover in Indonesia and 0.46 Mha in Brazil in 2012 only, mostly to make place for soya and oil palm plantations (Margono et al. 2). In addition, increasing demand for liquid fuels concurs with diminishing oil reserves to the expansion of biofuel crops, which also compete for land with food crops. Third, as highlighted in section 1.1. there are numerous feedbacks between the boundaries. Land use change is the main driver of biodiversity loss as well as a good predictor of the number of threatened species (Rockström et al. 474; Sala et al. 1772-1773). Clearings also release the biologically sequestered carbon stored in primary forests, releasing $\mathrm{CO}_{2}$ through direct burning of biomass and methane via bacteria which feed on decaying plant matter, therefore transforming the forest from a carbon sink to a carbon source (Gitz and Ciais). Finally, the complex feedbacks intrinsic in the Earth system virtually guarantee that unforeseen consequences to wholesale destruction of habitats are to be expected: for example, models show that removal of significant parts of the Amazon forests would result in modifying weather patterns as far as in the Northern Indian Ocean (7). To summarise, whilst Rockström et al.'s estimated land use change boundary might not have been reached yet, researchers' uncertainty is high. In addition, impact (I) is function of population (P), affluence (A), and technology (T):

$$
I=f(P, A, T) \text { (Alcott, “Impact Caps" 5). }
$$

According to this equation, it is likely that a growing, more wealthy population will increase its ecological impact, defined as pollution and depletion of resources. More efficient technology would theoretically be capable of reducing overall impact by increasing recycling rates and efficiency, and by substituting polluting and rare materials for common and harmless ones. However, given that population and affluence are rapidly increasing, and that-due to the laws of thermodynamics and Jevon's paradox-efficiency yields diminishing returns, it appears unlikely that technology will be able to offset increasing 
environmental impacts (M. Huesemann and J. Huesemann 120-121) 12 Ultimately, the trend towards the anthropisation of pristine ecosystems is likely to continue for the foreseeable future. The repurposing of previously undisturbed ecosystems, and the increasing impact of future populations will cause both foreseen and unforeseen negative consequences worldwide.

Having sketched a background of the global effects of changes in land use, I now focus my attention closer to home. The Mediterranean basin has experienced intense anthropogenic pressure on its ecosystems for millennia, and only 4.7 per cent of its original forest cover remains. However, the unique integration of natural ecosystems and traditional human activities has made this region an important biodiversity hotspot, especially because of the number of endemic plant species, second only to the Tropical Andes and Sundaland (including Borneo, Sumatra, Java and the southern half of the Malay peninsula) (Myers et al. 853-854). This balance has been upset in the last 40 years: "plains are being increasingly utilized, hilly and mountain areas are being abandoned by humans and naturally reforested, human settlements are quickly increasing along the coastline, with resident population doubling every 30 years and tourist presence doubling every 15 years" (Falcucci, Maiorano, and Boitani 618). The most striking changes in land usage are, in Italy, visible in the loss of "agriculture" and "pasture" lands, and in the dramatic increase in the "forest" lands as marginally productive lands are abandoned and revert to wilderness. From 1960 to 2000, lands used for agriculture fell from 37.89 per cent to 29.31 per cent of the Italian land area. In the same period, pasture collapsed from 18.72 per cent to 9.23 per cent of the Italian land area. The abandonment of formerly economically productive land determined a dramatic expansion of forested areas: 18.70 per cent in 1960 and 32.54 per cent in 2000. On the other hand,

\footnotetext{
${ }^{1}$ Poet Allen Ginsberg paraphrases the laws of thermodynamics in Ginsberg's theorem, comparing conservation of energy to a game. The theorem states: “1) You can't win; 2) You can't break even; 3) You can't get out of the game" (Wiggins 186).

2 Jevon's paradox or, the rebound effect, states that increased efficiency of industrial processes tends to offset or even increase the overall amount of resources used because efficiency pushes down the price of the resource, therefore stimulating demand (Alcott, "Jevons' paradox"; Sorrell).
} 


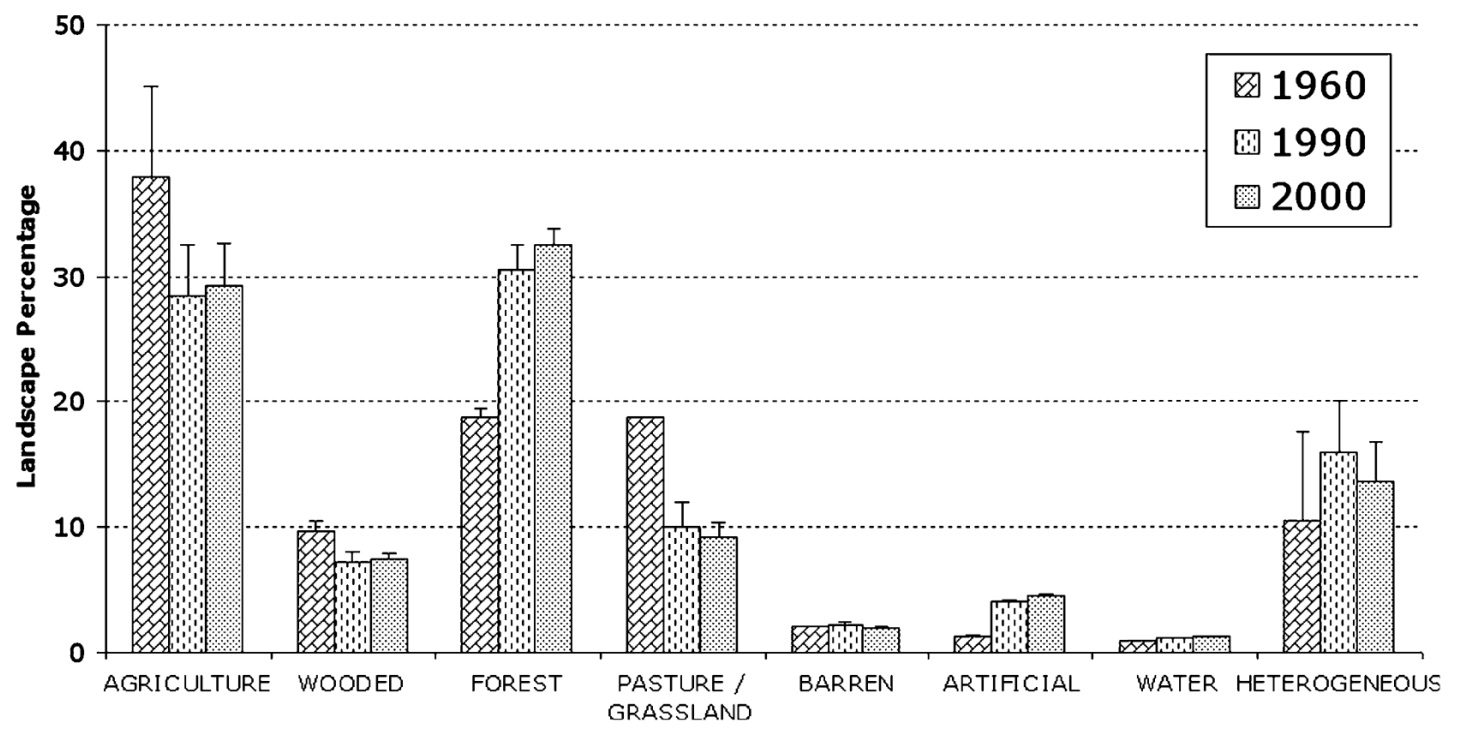

Figure 4.1: Falcucci, Maiorano, and Boitani, Percentage of the Italian peninsula occupied by the different land-use/land-cover classes in "Changes in land-use/land-cover patterns in Italy and their implications for biodiversity conservation" (Landscape Ecology, 2007) 622. Reprinted with permission from Springer Science+Business Media. 
areas classed as "artificial" have more than tripled: from 1.34 per cent in 1960 to 4.55 per cent in 2000, reaching a total area of 1,371,097 ha (Falcucci, Maiorano, and Boitani 621-622). This rapid reconfiguration of the Italian landscape has generated winners and losers in the affected ecosystems: whereas forestdwelling species such as the Italian brown bear (Ursus arctos marsicanus) and temperate forest birds have been expanding their range, other species dependent on the open spaces previously provided by pastures have become threatened or have disappeared altogether. The increase of artificial landscape surface has been especially prominent in Sicily, Sardinia and coastal areas, and has been attributed to the increase in tourist activities, which unsurprisingly happen in areas of outstanding natural beauty (628). Thus, paradoxically, biodiversity attracts tourist investment, and the development of tourist infrastructure destroys the ecosystems which sustains biodiversity.

\subsubsection{Narrating Land Use Change in the Twentieth Century}

Falcucci et al.'s analysis shows a rapid expansion of artificial surfaces between 1960 and 1990: it is a result of Italy's "boom edilizio" [building boom], which happened during the 1950s and early 1960s concurrently with the "miracolo economico italiano" [Italian economic miracle]. During this early phase of Italy's industrialisation, most of the expansion happened around big Northern urban centres. According to Istat, between 1951 and 1961, Turin increased its population by 42.6 per cent and Milan by 24.4 per cent ("Popolazione residente totale e popolazione residente dei centri abitati dei grandi comuni ai censimenti 1861-2001 e anno 2009 (ai confini dell'epoca) ") ? $^{3}$ Inadequate urban planning laws failed to contain this first building boom leading to sprawl and shanty towns built with no concerns for sanitation or hydrological stability (Graziano).

Even though it represents only a small (yet rapidly-growing) fraction of the

\footnotetext{
${ }^{3}$ Istat, or "Istituto nazionale di statistica" [National Institute of Statistics] is the foremost statistical institute of Italy. It produces and publishes data on behalf of the Italian government, coordinates the national census and organises economic, demographic and environmental surveys.
} 
total land area, the increase in the "artificial" landscape is especially interesting within the context of this research as it has undoubtedly catalysed the attention of many Italian authors and filmmakers. Vittorio De Sica's neorealist film Il tetto [The roof] (1956) dramatises the first building boom. Il tetto narrates the story of a poor young couple: an unskilled housewife and an apprentice bricklayer. The couple moves to Rome to find work in the building industry. Unable to find suitable accommodation, they resort to recruiting the help of family and acquaintances to build a shack during the time span of one single night. Building in such a limited timeframe was necessary because the authorities could order the removal of any building unless it was covered by a roof. After a failed attempt, they manage to complete their rudimentary home and, although a policeman notices that a section of the roof is still missing, he takes pity on the young couple and allows their shelter to stay. Vittorio De Sica takes a sympathetic view towards this first wave of necessity-driven illegal building.

The second stage of the building boom was centred around coastal areas and was driven by greed rather than necessity. As Italy's new bourgeoisie conquered unprecedented levels of wealth, tourism boomed. Owning a holiday home on the seaside became a status-symbol, and building rates in tourist areas soared-modern buildings replacing natural landscapes and historical landmarks. Intellectuals took a rather less sympathetic view of this second building wave: the "bassa marea morale" [moral low-tide] which fueled the second stage of the building boom was the inspiration for Italo Calvino's $L a$ speculazione edilizia [A Plunge into Real Estate] (1963), his first explicitly realistic and political novel (Italo Calvino, qtd. in "Presentazione" La speculazione edilizia). La speculazione edilizia offers an ironic portrait of Italian society during the economic boom. Italian society was at the time undergoing a series of dramatic changes, and entrepreneurs were supplanting the landowner class. In the novel, Quinto Anfossi is a politically left-leaning landowner in an unnamed city of the Ligurian Riviera recognisable as Sanremo, the city where Italo Calvino spent his childhood (McLaughlin, “Calvino's Visible Cities" 75). As Quinto approaches insolvency, he is contacted by Pietro Caisotti, a sly and brutal building contractor 
interested in developing his land. The fraudulent nature of Caisotti's deal is immediately evident to everyone, but Quinto ignores everyone's advice only to become entangled in a web of late payments, broken promises and litigation. Eventually, a worn down Quinto reconciles on terms totally favourable to Caisotti, "un sistema da farsi mangiare vivi da Caisotti" [[an] arrangement [which] would leave them wholly at Caisotti's mercy] (Calvino, La speculazione edilizia 135). ${ }_{4}^{4}$ Caisotti is thus La speculazione edilizia's undisputed winner. Spurred by the entrepreneurial (but unethical) spirit of the times, Quinto attempts to play Caisotti's game but his own good (or naïve) nature dooms him to defeat. Calvino explains that Quinto's "tentativo non può che essere sfortunato, perché in questo gioco sono sempre i peggiori che vincono, e fallire è proprio quello che lui in fondo desidera" [attempt cannot but turn out to be unfortunate, because the worst always win this game, and failure is exactly what he, deep in his heart, desires] (Italo Calvino, qtd. in "Presentazione" Calvino, La speculazione edilizia). Italo Calvino paints a Sanremo caught in the middle of a construction boom: "[l]a febbre del cemento s'era impadronita della Riviera: là vedevi il palazzo già abitato, con le cassette dei gerani tutti uguali ai balconi, qua il caseggiato appena finito, coi vetri segnati dai serpenti di gesso, che attendeva le famigliole lombarde smaniose dei bagni" [[t]he Riviera was gripped by a fever of cement. An apartment building here, the identical window boxes of geraniums on every balcony; there a building that had just gone up, the windows still marked with white, waiting for the Milanese families who wanted a place by the sea] (La speculazione edilizia 9 ). Undoubtedly, Calvino feels a pang of pain in seeing the flood of concrete supplanting Sanremo's extant landscape: Quinto's house "era un tempo circondata da giardini ombrosi d'eucalipti e magnolia" [had once been surrounded by shady gardens of eucalyptus trees and magnolias] but now "le scavatrici ribaltavano il terreno ... e la scure abbatteva in uno scroscio cartaceo ventagli delle palme di Washingtonia, dal cielo dove si sarebbero affacciate le future soleggiate-tricamere-servizi" [the bulldozers were churning up the soil ... the ax was at broad-leaved palm trees, which fell

${ }^{4}$ La speculazione edilizia translations by William Weaver, Difficult Loves (1983). 
with a papery scrunch from the sky so soon to be filled by the desirable, threeroom, all-convenience, sunny homes of tomorrow] (10). However, magnolias, eucalyptus and palms of the genus Washingtonia hardly represent species endemic of the Mediterranian maquis. Calvino merely witnesses the substitution of an anthropised landscape for another anthropised landscape. Calvino's La speculazione edilizia eschews ecological considerations and focuses on the representation of human behaviour: the fascination of risky business and its pernicious consequences, the degradation of the ideals of the Resistance and the loss of aesthetic values during Italy's economic boom (McLaughlin, “The genesis of Calvino's La speculazione edilizia" 76). Almost half a century later, these symptoms of social disease persist and have, despite efforts to curb them, worsened.

\subsubsection{The Foundations of Criminal Wealth}

According to Eurostat, 7.8 per cent of Italy's surface can be defined as artificial. By comparison, artificial landscapes cover 7.6 per cent of Germany, 6.5 per cent of the United Kingdom, 5.7 per cent of France (Eurostat, "“Land covered by artificial ${ }^{\prime}$ ). Considering that population in Italy is considerably less dense (201 inhabitants per square kilometre as of 2012) than in the United Kingdom (256.8 inhabitants per square kilometre as of 2010) or Germany (229.4 inhabitants per square kilometre as of 2012), Italian urban planners can be at the very least accused of inefficiently allocating space ("Population density”). But overbuilding does not just ensue from inefficiency or ineptitude: the problem of overbuilding in Italy has deep roots of illegality. Gian Vito Graziano, president of the Italian "Consiglio Nazionale dei Geologi" [National Council of Geologists], declared that illegal building in Italy "ha assunto proporzioni di scarso paragone con altre realtà continentali, giungendo ad assumere una rilevanza sociale, che in certe aree ... viene percepita al limite dell'ordinarietà" [has acquired dimensions which can hardly be compared to other continental realities, reaching a social relevance which, in some regions, ... is perceived to be close to the ordinary] 
(Graziano). The mayor of Casalnuovo di Napoli, when questioned about illegal buildings in his municipality, answered: "[n]essuno mi ha detto niente, non sapevo della realizzazione di questi palazzi: c'è da dire che sul posto vi sono alberi di alto fusto che impediscono la vista" [nobody told me anything, I did not know about the construction of these buildings: it has to be said that nearby there are tall trees which block the view] (Osservatorio Ambiente e Legalità, Ecomafia 2013 247). Wilful blindness not only affects ordinary citizens, but also authorities responsible for preventing the abuses. The first wave of necessityspurred illegal building, the complexity of Italian bureaucracy and the chronic cultural suspicion towards the State contributed to the relative acceptance of illegality. Since then, illegal building has become an obvious venue for organised crime to infiltrate and hijack apparently legal projects, warping them to suit their agenda:

[n]on ci si limita a chiedere il pizzo nei cantieri o nei negozi, ma si diventa imprenditori a tutto tondo: con la complicità di prestanome e compiacenti, la mafia si ritaglia uno spazio sempre maggiore nell'economia legale, entra nei capitali, apre i suoi supermercati, gestisce cantieri, assunzioni e forniture [[criminals] do not limit themselves to asking for protection money from building sites and shops, but they become all-round entrepreneurs: with the complicity of dummies and crooks, the mafia earns for itself an ever-growing share of the legal economy, accesses capitals, opens its supermarkets, manages building sites, hirings and supplies] (Osservatorio Ambiente e Legalità, Ecomafia 2013 229).

Revenues from the building industry provide a stable quasi-legal income for the criminal syndicates and allow them to launder money gained in other more overtly criminal activities. Moreover, much money is involved in the construction industry and illegal building is (just like waste disposal) a lucrative, low-risk business. It is easy for criminal organisations to bribe public servants, so that they turn a blind eye to prohibited practices, but some municipalities make criminal behaviour the rule rather than the exception: illegal construction 
and ignored demolition proceedings figure as one of the main reason for the forced disbanding of local governments in Campania (Osservatorio Ambiente e Legalità, Ecomafia 2012 202). National governments have further encouraged criminal behaviour by passing "condoni edilizi" [building amnesties], resulting in a wasted territory, infiltration of criminal organisations, and huge costs for local governments and the State (200). Building amnesties allow illegal buildings to be regularised for a fraction of the profit they generate. In addition, rumours about forthcoming building amnesties spur investment in illegal buildings as investors expect to be able to pay a small fee and regularise their position. WWF Italia calculates that the announcement of the 1985 and 1994 building amnesties directly caused 1.2 million buildings to be constructed (WWF Italia). Finally, repeated building amnesties encourage unscrupulous entrepreneurs who learn to rely on compliant governments to regularise their position.

Illegal building is a widespread environmental crime in Italy and its proportions are unmatched in other Western countries. It blights some of the most valuable corners of the country but it is, for historical and cultural reasons, tolerated or considered a minor infringement: repeated building amnesties have reinforced such response, and have encouraged organised crime to invest in illegal cement, another highly profitable and low-risk enterprise. Only 20 people were arrested in Italy for crimes related to illegal building in 2011, despite 6662 offences being detected and 8745 people being reported (Osservatorio Ambiente e Legalità, Ecomafia 2012 199-316). The Ecomafia reports and other authoritative sources paint a bleak picture of the state of the landscape in Italy, where unregulated building advances inexorably with little resistance from the institutions and little awareness from the population.

Twenty-first century Italian writers have offered interesting literary responses to land-use change from different perspectives, to different audiences and through different uses of language. In Rovina, Simona Vinci narrates the personal tragedies ensuing from the reckless practices of the building industry and its links with organised crime. Giancarlo De Cataldo's Fuoco! introduces the themes of wildfires and environmental crime to a young readership. Finally Roberto 
Saviano's Gomorra endeavours to explain the criminal dynamics which make cement one of the most profitable industries for the Camorra. Beyond their differences, these three texts all highlight in distinct ways the involvement of organised crime in degrading Italy's natural heritage. They provide an introduction to the dynamics of land use change. Most notably, the three works suggest in terms suitable to their respective readerships that the only way to break the domination of organised crime is through an increased awareness of the problems of property speculation which has to culminate in civil resistance. Rovina and Gomorra seem to be especially closely linked, with characters and mechanisms returning in both works: Simona Vinci's Candida C. is evidently Immacolata Capones's alter-ego and Carmine D.'s description of the working conditions in construction yards resonates with Saviano's account of his stint as a construction worker, as well as with his description of the criminal practice of disposing of scrubber dust in cement. Rovina was published in 2007 and Gomorra in 2006, so it is entirely possible that Vinci may have drawn ideas and inspiration from Saviano. Critically, the shared element which links the three works is the use of autofiction. Roberto Saviano, Simona Vinci and Giancarlo de Cataldo intrude into their own narration as Saviano the character/narrator, Simona V. and Carandini delle Mole. This strategy creates a double-link between narrative and reality, turning readers' "willing suspension of disbelief" into an invitation to modify their world-views, therefore providing an antidote to denial and a platform for further investigation into the processes of land use change in Italy.

\subsection{A Story of Places and People: Rovina}

The novel Rovina was published in 2007 as part of the VerdeNero series. The author, Simona Vinci, is a novelist, translator, journalist and radio host. Her first book, Dei bambini non si sa niente (1997), won the "Elsa Morante" prize in 2000. Her novels In tutti i sensi come l'amore (1999) and Come prima delle madri (2003), were finalists of the "Premio Campiello". In Rovina, Simona Vinci builds a bridge across the chasm separating the reader from the awareness 
of an eroding landscape through the use of noir narrative. As I have argued, narrative is seductive because it translates reality into terms that humans find easier to digest. In addition, narrative enables readers to access a vantage point from which to examine normally hidden sides of reality. But why did Vinci choose the noir genre for this novel? The answer to this question is multifaceted. Vinci is aware of the fact that noir narrative connects with a large number of Italian readers. In an interview, Vinci explains that "[i]l noir italiano è riuscito a raccontare molte cose del nostro Paese, in un modo accattivante e che ha conquistato anche lettori magari non forti..." [Italian noir succeeded in narrating many things about our country, in a captivating way which has won over even those who are perhaps not very strong readers...] (Geraci). Vinci explains that she wrote about environmental crime in the simplest possible way so as to elicit an emotional response from her readers: "Ho cercato di scrivere un racconto che mettesse in scena un meccanismo e che andasse a colpire l'emotività di chi legge, nel modo più semplice possibile" [I tried to write a story which staged a mechanism and which influenced the reader's emotions, in the simplest way] (Bolelli). Also, noir narrative is traditionally well-suited to engaging with social issues. Already in 1960, Leonardo Sciascia subverted the "romanzo giallo" [detective fiction] structure and injected elements of social critique in his Il giorno della civetta [The Day of the Owl] (1961). Sciascia's novel denounces the climate of omertà predominating in Sicily, and the links between powerful politicians and the mafia, helping readers understand the real nature of the criminal organisation as a "borghesia parassitaria" [parasitic bourgeoisie]. As Sciascia wrote in the appendix of the 1972 edition of his novel, a renewed awareness of the mafia closely followed the publication of his novel:

Ho scritto questo racconto nell'estate del 1960. Allora il Governo non solo si disinteressava del fenomeno della mafia ma esplicitamente lo negava. La seduta alla Camera dei Deputati, rappresentata in queste pagine, è sostanzialmente, nella risposta del Governo ad una interrogazione sull'ordine pubblico in Sicilia, vera. E sembra incredibile: considerando che appena tre anni dopo entrava in 
funzione una commissione parlamentare d'inchiesta sulla mafia [I wrote this story in the Summer of 1960. Back then, the government not only ignored the phenomenon of the mafia but it denied it explicitly. The meeting of the Chamber of Deputies, portrayed on these pages, in response to an interrogation about law and order in Sicily, is substantially true. And it seems unbelievable than only three years later, a parliamentary commission to investigate mafia came into being] (Appendix).

However, it cannot be ascertained whether the success of Sciascia's novel contributed to bring the phenomenon of the Mafia to public attention or whether, as Laura Pugno argues, it is more true that writers are "un po' come dei radar rispetto al proprio tempo, che intercettano tematiche che in qualche modo sono nell'aria" [are a bit like radars of their own time, intercepting themes which are somehow already floating in the air] (Appendix C "Intervista a Laura Pugno"). Nevertheless, just as Leonardo Sciascia employed his writing skills to highlight the deviant social phenomenon of the mafia, with Rovina, Vinci exploits the popularity of the noir genre to disseminate a call-to-arms against abuses of the landscape.

Rovina means "ruin" in Italian, both in the sense of "[ $\mathrm{t}]$ he state or condition of a fabric or structure, esp. a building, which has given way and collapsed" and "[t]he state or condition of a person who or society which has suffered decay or downfall" ("Ruin"). Both nuances are relevant to the novel, as becomes apparent when reading its two epigraphs, one from Nathaniel Hawthorne's American Notebooks (1853) and one from Antonio Cederna's I vandali in casa (1965). In her Rovina, Simona Vinci shows that everyone stands to lose from environmental crimes, and in particular from the criminal system which trades the living world for privatised profit. The novel tells the stories of people who have been variously implicated in the construction of a residential area, called "La Nuova Aurora" (Vinci, Rovina 8). Although the exact location of the area is not mentioned, Simona Vinci provides hints that allow the reader to locate the neighbourhood with relative accuracy: it is situated "[v]enti chilometri 
da Parma e cinque da Reggio. Lungo la via Emilia" [twenty kilometres from Parma and five from Reggio. Along the via Emilia], close to a stream and a small wooded area (24-25). The coordinates would indicate that the "La Nuova Aurora" development lies near or within the town of Pieve Modolena, situated between Reggio Emilia and Parma on a stream named the Modolena.

\subsubsection{The Structure of Ruin}

Rovina is structured as a collection of seven short stories. Each story occupies a chapter and in each chapter a different person explains in a first-person monologue his or her role in the event and how he or she was ruined. In an interview, Simona Vinci tells Anna Satolli that "ognuno dei personaggi in scena confessa a qualcuno la sua storia e le sue colpe. La forma giusta era per forza il monologo. Attraverso gli indizi che vengono fuori dai monologhi ho costruito la vicenda" [each character on stage confesses to someone his or her story and wrongs. The right form was necessarily the monologue. I built the event through the clues that emerge from the monologues] ("Morire di cemento"). The identity of the characters' implied and silent interlocutors can be inferred through clues dropped during the confessions (see table 4.1). This setting underlines the loneliness and the desperation of the characters who, like souls in Dante's Inferno, confess their crime without any hope for redemption.

In the same interview, Vinci claims that she imagined Rovina as "una sorta di tragedia greca" [a sort of Greek tragedy] (Satolli). What does the structure of Vinci's text tell us about her animus narrandi and about the text? Although Greek tragedies present a wide variety of configurations, convention subdivides them into a prologue, a parode and three to five prosaic episodes each followed by a stasimon, where the chorus comments or reacts in lyrics to the events presented in the episode. Finally, the chorus sings the exodus, closing the tragedy. It is thus possible to directly compare the structure of Rovina with that of Greek tragedy. The first introductory section functions as a parode. Then, each chapter narrates the personal tragedy of a character in monological form. After each chapter, an 


\begin{tabular}{|c|c|c|}
\hline Character & Interlocutor & Reference page \\
\hline Annamaria L.G. & A television journalist & 9 \\
\hline Fabio e Marilena Z. & Their lawyer & 26 \\
\hline Sara G. & Her psychiatrist & 62 \\
\hline Mario F. & A judge & 85 \\
\hline Carmine D. & A blogger (?) & $89-90$ \\
\hline Candida C. & "dio" [god] & 106 \\
\hline Simona V. & The reader & - \\
\hline
\end{tabular}

Table 4.1: Rovina's characters, their interlocutors and page.

entr'acte describes from an impersonal perspective how the landscape around the "Nuova Aurora" is being lost to cement. The final section, which functions as an exodus, is Antonio Pergolizzi's "I fatti", which places the anecdotes reported in the novel in the wider context of ecological crime in Italy ${ }^{5}$

Table 4.2 makes it evident that there are only two main differences between Vinci's Rovina and Greek tragedy. The first is the lack of a prologue. However, some Ancient Greek tragedies such as Aeschylus' The Persians and Seven against Thebes also lack a prologue. The second difference is one of quantity rather than quality, because Vinci's novel comprises seven episodes instead of the three to five which are normally found in a Greek tragedy.

The structural parallelism between Rovina and Greek tragedy allows the author to expose the social and environmental costs of overbuilding. Just as death and downfall are irreversible, Simona Vinci shows that cement destroys ecosystems and landscapes forever. For the profit of few, "a tutti gli altri viene sottratto qualcosa di cui poi è impossibile riappropriarsi: dal cemento ... non si torna indietro" [everyone else is deprived of something which it is impossible to

\footnotetext{
5 "I fatti" is a special section which closes most VerdeNero books. This part is authored by Antonio Pergolizzi, coordinator of the Osservatorio Ambiente e Legalità, the institution which publishes the Ecomafia reports. "I fatti" summarises the themes already explored in the book providing an overview of the available data on the issue. It also adds observations that extend the scope of the text and help readers draw a link between fiction and reality.
} 


\begin{tabular}{|c||c|}
\hline \multicolumn{1}{|c||}{ Rovina } & Greek tragedy \\
\hline & Prologue \\
\hline Introduction & Parode \\
\hline Annamaria L.G. & Episode 1 \\
\hline Entr'acte & Stasimon \\
\hline Fabio e Marilena Z. & Episode 2 \\
\hline Entr'acte & Stasimon \\
\hline Sara G. & Episode 3 \\
\hline Entr'acte & Stasimon \\
\hline Mario F. & (Episode 4$)$ \\
\hline Entr'acte & (Stasimon) \\
\hline Carmine D. & (Episode 5) \\
\hline Entr'acte & (Stasimon) \\
\hline Candida C. & \\
\hline Entr'acte & \\
\hline Simona V. & \\
\hline I fatti & Exodus \\
\hline
\end{tabular}

Table 4.2: Comparison between the structure of Rovina and Greek tragedy. 
reclaim: there is no turning back ... from cement] (Vinci, Rovina 122). There is another reason why Simona Vinci structured Rovina like a Greek tragedy. For the Greeks, tragedies were more than just entertainment, but provided a way to correct the weaknesses intrinsic in the human condition through the mechanism of catharsis which I have illustrated and defined in section 2.4.2. Through the process of catharsis and mourning which tragedies initiate, citizens learn the disastrous downsides of real estate speculation, consciously explore and learn to manage their own emotional reaction to the narrative, turning from denial and frustration to a positive and constructive outlook. Finally, they create links with the reality they inhabit and reinvest the emotive capital they have earned into social action: "[d] evono essere i singoli cittadini a opporsi alle speculazioni edilizie, alle mani lunghe delle mafie, visto che della classe politica non ci si può fidare in nessun caso" [individual citizens have to oppose rampant overdevelopment, the mafias' sticky fingers, because we cannot in any way trust the political class] (Bolelli). Most importantly, awareness allows citizens to resist the capitalist narrative according to which the world's problem can only be solved through increased economic and industrial activity, of which cement is but one manifestation.

However, Rovina is an imperfect tragedy. First of all because, as we have seen, its structure presents differences compared to a classical Greek tragedy. But most importantly, unlike Greek tragedy, Rovina leaves the door open to hope and to remedying action - or at least to resistance. In the seventh, autobiographical chapter, Simona Vinci writes: "in posti così bisogna essere indignati, e di continuo. Abituarsi, certo, forse ci si abitua a tutto, ma questo vuol dire essere complici, in qualche modo" [in places like this you have to be constantly indignant. You get used to it, sure, maybe you get used to everything. But this means turning into an accomplice somehow] (Vinci, Rovina 111). Indignation is a reaction to injustice. Although it is mostly powerless, indignation highlights a problem and inhibits denial. Most importantly, it offers the indignant an opportunity to come to terms with injustice using both mitigating and adaptive strategies. The mitigating strategies are denouncing and not partaking in 
injustice:

[è] dovere di ogni singolo cittadino opporsi a questa oscena speculazione che ci priva tutti quanti della risorsa che dovrebbe essere nostra di diritto ... È inaccettabile. Ammetto la mia ossessione, ma temo che se non ci si lascia ossessionare da mostruosità del genere, TUTTO finirà nel cemento. E nelle mani di uomini che è impossibile guardare senza provare il bisogno di distruggerli ... [it is the duty of every single citizen to oppose this obscene real estate speculation which deprives us all from the resource which should be ours by right ... It is unacceptable. I admit my obsession but I fear that if we do not let ourselves be obsessed with such monstrosities, EVERYTHING will end up in cement. And in the hands of men it is impossible to look upon without feeling the need to destroy them]

The adaptive strategy is coming to terms with the possibility of undesirable outcomes. Vinci is aware of the fact that activists are fighting an uphill battle. The beauty of natural landscapes is set against the ethos of perpetual industrial growth. For as long as human activity is motivated by profit and faith in unchecked growth, ecosystem degradation can be perhaps slowed, but never stopped or reversed. Vinci realises this and writes: "Probabilmente accadrà comunque. But not in my name [English in the original text]" [Perhaps it will happen anyway. But not in my name] (Vinci, Rovina 122). The possibility of ultimate defeat overshadows her activism but she believes she has no choice but continue to oppose criminal development.

\subsubsection{A Landscape of Denial}

Observing the same episode from a number of points of view gives the reader an impression of the complexity and importance of the phenomenon of overbuilding. No one is innocent in Rovina: characters are shown as being authors of their own demise. However, this understanding does not negate the emotive reaction to witnessing such misery unfold as readers will recognise 
familiar thought patterns at work: most of Rovina's characters just want to live a quiet life, others want love, wealth, or power. A quiet, routine life is desirable in normal circumstances but sometimes, independent from our will, extraordinary events arise and subvert long-standing orders, requiring immediate attention, action and a change in habits. Facing complex and intractable problems is a painful and frustrating proposition and a common reaction to such challenges is denial, an avoidant coping strategy which allows subjects to act as if the problem did not exist (see section 2.4.2). Rovina's narrative strategy allows the reader to connect with some characters and understand how average mindsets can become embroiled in tragic events. Clearly, such responses will be subjective, and readers may find it harder to empathise with characters possessed by extreme passions. However, the apparent normality of the characters' behaviour leading to extraordinary and tragic consequences has a double effect on the reader. First, it encourages the development of compassion (in its truest and original meaning of "suffering together"). And second, the compassion may induce readers to investigate some aspects of their own so-called normality.

\section{Denial Comes at a High Price...}

Denial affects all the characters in Rovina, except three: Candida C., Carmine D. and Simona V., though for fundamentally different reasons. The remaining characters extensively engage in denial. Vinci uses her characters' behaviour to reveal how the mechanism of avoidant coping is ingrained in normality and how it contributes to the downfall of each of them. Vinci introduces Rovina's characters in increasing order of involvement with the construction of the "Nuova Aurora". Annamaria L.G. is a naïve primary school teacher who witnesses Candida's murder and relates her story to the television journalists who have come to interview her. Ruin is, for Annamaria, loss of a sense of safety after Candida's murder shatters her village's quiet routine (Vinci, Rovina 9, 17). Through her deposition, Vinci exemplifies the grossest example of denial whereby the subject actively rejects unpleasant aspects of reality and exhorts others to do the same. Annamaria's philosophy is: "meglio non vedere e non 
sentire che se non vedi e non senti, nessuno viene a chiederti conto di niente e nessuno ti può fare del male, tu te ne stai tranquillo e beato ... come le piante bisogna stare, senz'occhi, né orecchie, né lingua" [better not to see and not to hear because if you don't see and you don't hear, nobody can bother you and nobody can harm you. You can live quietly and blissfully ... you have to be like plants, with no eyes, nor ears, nor tongue] (17). Annamaria's desire to achieve a vegetative state whereby she is deprived of all contact with the world highlights the childish deplorableness of omertà: a deadly mixture of fear and delusion which leads some to believe that it is possible to flourish through ignorance and acquiescence to evil.

Fabio and Marilena Z., a young couple of first-home buyers who lose their savings and their dream of owning a home, offer a second example of denial. They, too, choose not to see potential trouble: Marilena, an employee of the municipality, notices some irregularities in the paperwork related to the residential complex "La Nuova Aurora" but she "non aveva voluto indagar oltre, aveva chiuso gli occhi e si era detta speriamo che vada tutto bene, come quando si passa in macchina davanti a un incidente e si decide di non guardare, di girare la testa e di pregare" [did not want to investigate further, she looked the other way and told herself, let's hope for the best, like when you drive past an accident and you decide not to look, to turn your head and pray] (Vinci, Rovina 31, 32). Even though their denial is not as extreme as Annamaria's, Fabio and Marilena pay a hefty price for letting their desires make them blind to caution, but they are not alone in their misery. Sara is a nurse who had co-owned with her father the land upon which the "Nuova Aurora" was to be built. Mario F., a married contractor and surveyor, seduces her in order to convince her to sell the land. Sara's critical skills become dulled by the promise of money, love, and happiness: "mi faceva gola l'idea perché con quei soldi lì, pensavo, [io e Mario] avremmo anche potuto prender su e andare a vivere che ne so, in Sudamerica, o su una bella isola" [I was tempted because with that money, I thought, [Mario and I] could have gone to live-I don't know-in South America or on a nice island], she confides to her psychiatrist (39). However, 
a rude awakening shatters her dream: her father commits suicide because he is unable to cope with the loss of the landscape he grew up with and Mario is shown as a soulless opportunist. Sara sees "il futuro che avev[a] immaginato trasformato in un cumulo di letame che si afflosciava su se stesso, un castello di sabbia trascinato via da un'onda troppo violenta, un palazzo che crolla in una nuvola di polvere..." [the future [she] had imagined transformed into a pile of manure collapsing on itself, a sand castle swept away by a powerful wave, a building crumbling in a cloud of dust. . . (51). Mario F. causes Sara's ruin through his cynical act of seduction but the game he plays has no winner and his dreams of wealth are, in turn, sabotaged. Mario's tale begins as the entrepreneur Giuseppe S. offers him "l'affare della [sua] vita" [a once in a lifetime deal]. As was the case with Sara, Fabio and Marilena, dreams cloud Mario's critical skills. He abandons caution and decides to turn a blind eye to Giuseppe's clear links to organised crime. Although on many occasions Mario becomes suspicious of Giuseppe's background and intentions, he concludes that "[q]uando si tratta di capitali da investire, è inutile starsi a chiedere da dove vengono, l'importante è che ci siano" [when it comes to investing capital, it is useless to ask yourself about its provenance, the important thing is that it is there] (69). As we have seen before, this is an all-too-common mindset among businesspeople, the primary mechanism that allows the Camorra to launder its criminal wealth. Just as happens to Sara, Fabio and Marilena, his dreams soon turn into a nightmare. Investigators stop the building works at the "La Nuova Aurora" because of tax irregularities and Giuseppe S. is revealed to be a swindler. Vinci portrays Mario as an amateurish yet ruthless building contractor "ossessionato dall'idea del 'guadagno'" [obsessed with the idea of 'profit'] who does not think twice about trampling over Sara's life. Vinci admits she could not empathise with such a character (121). Ultimately, fate (or, authorial intention) repays Mario's greed with the same coin he served Sara: "per [Giuseppe S.] ero uno tra altre decine di intermediari, che di pesci piccoli come me nella sua rete ce ne aveva infilati tanti e adesso siamo tutti lì lì per cadere nella padella dell'olio bollente..." [for [Giuseppe S.], I was one of the dozens of intermediaries. He had so much small 
fry like me in his net and now we are all about to fall into the frying pan] (84). Vinci presents Mario's misadventure as a moral tale of unbridled dog-eat-dog capitalism, a game whose rules reward unethical behaviour and ruthlessness, and which ultimately leads to the demise of all those who play it.

\section{... But Acceptance Does Not Come Cheap Either}

Witnessing the behaviour of the remaining characters, of those who avoid to engage in denial, also rewards the reader with important insights. Candida C., we learn in the first chapter, is an entrepreneur with "amicizie importanti, gente grossa, gente di quella che decide le cose, politici" [important friendships, bigwigs, people who make decisions, politicians]. She can count, among her "friendships", Rosetta Cutolo-the only person in the novel whose surname is not abbreviated. This is because, unlike Candida, Rosetta Cutolo is a real person, who led the criminal organisation "Nuova Camorra Organizzata" (NCO) after her brother Raffaele Cutolo was caught and until her arrest in 1983. Thus Candida is not in denial because she actively chose the criminal career and, until her death, she was a winner. Now, with her death, as her stake was the highest, she loses the most: her life and, possibly, her soul as her chapter ends with her pleading to god to let her into heaven (Vinci, Rovina 106).

The second character not in denial is Carmine D., a construction worker. He relates a first-hand account of the harsh conditions of labourers in construction yards throughout Italy and embodies the antithesis of Annamaria's naïve, reality denying worldview: "io tengo una memoria d'elefante, sarà pure che il posto da dove vengo io è un posto che c'è poco da scherzare, ricordarsi le facce e i nomi, e chi ha fatto cosa e quando e come... è questione di sopravvivenza, sempre con gli occhi aperti e le orecchie per terra bisogna stare se no ti ritrovi all'improvviso a gambe all'aria" [I have got a memory like an elephant, maybe it is because the place I am from is no joke: remembering faces and names, and who did what and when and how... is a question of survival. You always have to keep your eyes open and your ears on the ground, otherwise you suddenly find yourself belly up] (Vinci, Rovina 90). Carmine is aware of the risks associated with his 
profession but feels as though he has no choice but "string[ere] i denti" [to grit his teeth] -literally and figuratively (92). It is often the case that labourers operate under illegal working conditions: INAIL estimates that over 3 million people were working irregularly in Italy in 2010 in all sectors (Rapporto Annuale 2011). 6 The FILCA workers' union reports that 10.5 per cent of the workforce in the Italian building industry operates under illegal conditions (Petrelli). 1 Carmine, having injured himself in the workplace, has no choice but to disregard medical advice because, he says, "l'assicurazione ce l'ho per finta, me l'hanno detto subito, patti chiari amicizia lunga, se ti fai male, poche storie e via" [my insurance is fake, I was told straight away: clear agreements make for long friendships, if you hurt yourself, no complaints and get lost] (Vinci, Rovina 92). Vinci uses Carmine's testimony to illustrate the inhumane conditions in which building workers operate, and which caused 195 reported deaths and 74 thousand accidents in 2011 alone (Rovina $91-92$; Istituto nazionale per l'assicurazione contro gli infortuni sul lavoro, "“Costruzioni|'). It should be noted that those numbers are likely to be a serious underestimate for at least two reasons. First, casualties among irregular workers are unlikely to be reported (Rapporto Annuale 2011 2). Second, it ignores long-term harm such as diseases caused by exposure to dangerous materials. In his testimony, Carmine says that "insieme al cemento arrivavano pure un tot di tonnellate di robe diverse, erano polveri, dovevamo mescolarle alla malta, sacchi bianchi e sacchi bianchi con una riga nera, bidoni azzurri e bidoni blu, in una quantità precisa. Che era meglio se si respirava poco non ce l'ha detto nessuno a noi manovali ma io l'ho capito subito..." [with the cement, we received a few tonnes of different kinds of stuff-powders. We had to mix them with the mortar: white bags and white bags with a black line, sky-blue barrels and blue barrels, in specific proportions. No one told us labourers not to breathe too much but I understood it immediately...] (Vinci, Rovina 97). The technique of disposing of dangerous

\footnotetext{
${ }^{6}$ INAIL: Istituto nazionale per l'assicurazione contro gli infortuni sul lavoro [National Institution for Insurance against Accidents at Work].

${ }^{7}$ FILCA: Federazione italiana lavoratori costruzioni e affini [Italian Federation of Construction Workers and Similar].
} 
substances by mixing them with concrete is not Vinci's invention and evidences a deeply unsettling link between the cycle of cement and the cycle of waste. The Ecomafia 2005 report, which was available to Vinci when she wrote Rovina, talks about "polveri di abbattimento fumi ... miscelate insieme al cemento o nelle fornaci per la produzione di laterizi ..." [scrubber dust ... mixed with cement or in the furnaces to produce bricks .... (Osservatorio Ambiente e Legalità, Ecomafia 2005 33). Four years later, in 2009, the "Black Mountains" investigation revealed that highly toxic industrial detritus was being mixed with concrete used to build roads, homes, schools and even an aqueduct in Crotone, Calabria. Analyses found abnormal levels of arsenic, zinc, lead, indium and mercury in the students attending the affected schools, which could lead to gastrointestinal, kidney and bone diseases (Ecomafia 2010 80-81). Carmine knows that his profession is killing him and the desperate who, like him, need to earn a living in the construction industry but he cannot find alternatives: "in questo mestiere mio è come per i calciatori, si dura poco... solo che i calciatori alla fine ci fanno pure i miliardi e io resto con una gamba zoppa e un calcio in culo..." [my profession is like being a footballer, you don't last long... However, footballers earn billions while I am left with a lame leg and a kick in the ass... ] (99).

The last character to appear in the novel is Simona V., the author's autobiographical voice and the only non-fictional character of the novel. Simona V. lets her indignation propel her to action: "[s]ono di nuovo qui a guardare, a prendere appunti, a fotografare" [I am here again looking, taking notes, photographing] (Vinci, Rovina 110). For Simona V., action and imagination have been an antidote to passivity, denial and despair: "è così che ho cominciato a immaginare una storia. Solo che questa ... era una storia che non mi permetteva di restarmene chiusa in casa davanti al computer, come più o meno avevo sempre fatto, ma mi chiedeva di uscire, di attraversare il parco, raggiungere la strada e mettermi a camminare" [and it was so that I began to imagine a story. Only ... this was not a story which allowed me to stay at home in front of the computer, as I had always more or less done. It required me to go out, across 
the park, to the road and start to walk] (115). Thus, after providing a diagnosis for the illness that affects the Italian countryside, Vinci also provides the cure: leaving one's home, and walking beyond one's comfort zone. Most importantly, opening one's eyes and witnessing develops critical skills that prevent us from falling victim to the denial and the wishful thinking which curse many Rovina's characters.

\section{Finding Justice in an Imperfect Tragedy?}

Vinci's novel is a call-to-arms against the impoverishment of the Italian landscape and wildlife. The philosophy of "quieto vivere" is inappropriate in an age where criminal syndicates trample on people and virgin lands alike and, because ordinary justice is too slow and inefficient to prevent all crime, citizens have to stand up and protect the res publica through grassroot action. To this end, Rovina elicits empathy in its readers and uses the consequent emotional potential to begin a cathartic process which contaminates them with a mixture of hope, indignation, and despair. The varied human experiences of loss and grief of Rovina's fictional characters provide a mirror through which readers may see themselves. At the same time, Vinci applies the law of contrappasso to satisfy her readers' innate sense of fairness showing that accomplices of crime always become its victims: Annamaria L.G., Fabio and Marilena Z., Sara G., Mario F. and Candida C. all come to harm because of their own involvement in (or failure to denounce) crime. This reflection may lead readers to consider that denial and wilful ignorance, far from being viable defensive strategies, effectively turn innocent citizens into accomplices and victims. However, this is only part of the process of healing literary writing can offer: poetic justice hardly ever occurs outside fiction and thus can offer only a fleeting sense of relief. Ultimately, Vinci calls her readers to the much more ambitious and satisfying task of personally standing up against environmental crime.

This is an "imperfect tragedy" strategy, that is, the building of tragic innuendo followed by a sudden epiphany which offers to characters and society an alternative to compliance with evil. It is noteworthy that this theme 
is present in all of the works already discussed: the reader will remember Saviano's final rebellious call against the Camorra, Tamerlano's transformative nigredo and Antonio's desperate desertion of Giuliano's psychotic tyranny. Similarly, Simona V.'s fervent reaction to the destruction of Emilia-Romagna's traditional landscapes offers a possible matrix to turn the widespread feeling of powerlessness in the face of the arrogant advance of what Antonio Cederna called "una repellente crosta edilizia" [a repulsive built-up scab] into awareness and perhaps a resistive social force ("Parco Nazionale d'Abruzzo").

\subsection{Wild Passions and Wildfires: Fuoco!}

Born in Taranto (Apulia) in 1956, Giancarlo De Cataldo is a judge and a prolific novelist, screenwriter and playwright. He has published more than 20 fiction and non-fiction works and a theatre play, Acido fenico. Ballata per Mimmo Carunchio cammorrista [sic]. In addition, he wrote the scripts for more than 15 television series and films. His best-known novel is Romanzo criminale (2002), a glamourised account of the history of the "Banda della Magliana" 8 In 2009, De Cataldo published Nelle mani giuste [In the Right Hands], a sequel to his Romanzo criminale set in 1992-1993, the years when Cosa Nostra enacted a terrorist strategy against the Italian state, targeting several high-profile public figures and locations throughout Italy with indiscriminate bomb attacks which cost the life of 21 people. Among the victims were the judges Giovanni Falcone and Paolo Borsellino, who were murdered because of their commitment to fighting organised crime, but also politicians, entrepreneurs, religious figures, and civilian bystanders. The killing of bystanders was deliberate as this strategy was not only aimed at eliminating inconvenient public figures. The targeting of

\footnotetext{
8 The "Banda della Magliana" was a powerful and violent criminal gang that formed in the late 1970s. Historically, it obtained its revenues and from kidnappings, drug trafficking, illegal gambling, and prostitution. It could count on support from extreme right groups, the Sicilian Mafia, the subversive Masonic lodge "Propaganda Due" (P2), and deviated branches of the Italian secret services. Although many of its affiliates are dead or imprisoned, it is doubtful whether its activities have been completely suppressed.
} 
famous landmarks such as the Galleria degli Uffizi in Florence, the Padiglione d'arte contemporanea di Milano and even the Stadio Olimpico in Rome proves that Cosa Nostra aimed to create a climate of terror, to intimidate the nascent civil resistance against organised crime and to force the Italian state to negotiate and compromise with the Mafia. ${ }^{9}$ De Cataldo's work as a screenwriter focuses on crime, including the television adaptations of his Romanzo Criminale (made both as a film and a television series), and notorious episodes of Italy's recent history such as Paolo Borsellino (2004) and Il caso Enzo Tortora - Dove eravamo rimasti? (2012).

De Cataldo is also the author of Fuoco! (2007), a novel about teenagers facing the challenge of becoming adults. Just like Rovina, Previsioni del tempo and Delta blues, De Cataldo's novel was published as a part of the VerdeNero series, and the author's name almost certainly contributed to its record sales ("Se l'autore entra nelle tenebre dell'ecomafia"'). In Fuoco! De Cataldo popularises the issue of criminal cartels resorting to arson to further their aims. Most of the action is set around the fictitious town of Porto Meraviglioso [Port Wonderful] located in Apulia "a metà strada fra le città di Taranto e di Lecce" [midway between the cities of Taranto and Lecce] (De Cataldo, Fuoco! 36). De Cataldo's novel links the wildfires which ravage Southern Italy to the criminal logic of the Camorra and suggests that the fires will only stop when their real cause is fully understood and citizens develop the necessary awareness and courage to protect Italy's heritage of biodiversity. The author claims that he was inspired to write Fuoco! after feeling the heat and smelling the smoke of the wildfires burning in Apulia: "[l]'idea mi è venuta scendendo a Sud l'estate scorsa. Lungo la strada, in Puglia, c'erano tutti questi incendi, veri, impressionanti. Non è come vederli in televisione, dove sembrano freddi, maestosi: lì c'era calore, puzza, fumo. Una vera devastazione" [I had the idea while travelling South last summer. Along the road, in Apulia, there were all these fires, real, impressive. It is not like watching them on television, where they look cool, majestic: there was heat, smell, smoke

\footnotetext{
${ }^{9}$ The first two attacks claimed five victims each and are known as "strage di via dei Georgofili" and "strage di via Palestro". The attack on the Stadio Olimpico failed because the car bomb malfunctioned and did not detonate.
} 
there. Real devastation] (Trabace). This real-life episode inspired De Cataldo to write Fuoco!, a novel which "non è una storia vera. Forse è una storia possibile, ma ... mancano le prove" [is not a true story. Maybe it is a possible story, but ... there is no evidence] (Fuoco! 221). De Cataldo relates a fictional story set against the backdrop of a burning Apulia. However, he clarifies that, although Fuoco! is fictional, it is a possible story, albeit one that cannot be verified. What does this mean? In other words, what are the fictional elements in Fuoco! and what are the possible ones?

\subsubsection{A Burning Issue: Wildfires in Italy}

Legambiente and the Dipartimento Nazionale della Protezione Civile [National Department for Civil Protection] published in 2011 the Ecosistema incendi report with statistics about the number and extension of wildfires during the 20072010 period. Since 2008, the Corpo Forestale dello Stato (CFS) publishes a yearly report titled Incendi boschivi about their fire-fighting activities, with statistics disaggregated according to number and extension of wildfires by region and by month of the year ${ }^{10}$ Although the CFS published no report with disaggregated wildfire data prior to 2008, their Incendi boschivi 2010 - Tabelle e mappe regionali pamphlet provides a breakdown of 2007 statistics which mirrors data from the Ecosistema incendi report with only minor discrepancies. Analysing the data by macroregion (North, Centre, South, Islands), it becomes immediately apparent that the great majority of wildfires occurred in the South and in the Islands (see figures 4.2 and 4.3) (Legambiente and Dipartimento Nazionale della Protezione Civile $3-4)$.

While it is true that the Southern regions and the Islands experience a more arid climate, in Italy, the great majority of wildfires are started deliberately (Legambiente and Dipartimento Nazionale della Protezione Civile 6). Although statistics are available, it is difficult to compare them because in 2012 the CFS

\footnotetext{
${ }^{10}$ Corpo forestale dello Stato [State Forestry Corps]: an Italian police corp specialised in the protection of Italy's natural resources and its environment. Its activities include the suppression of poaching, investigation of environmental crimes, prevention and extinguishing of wildfires.
} 


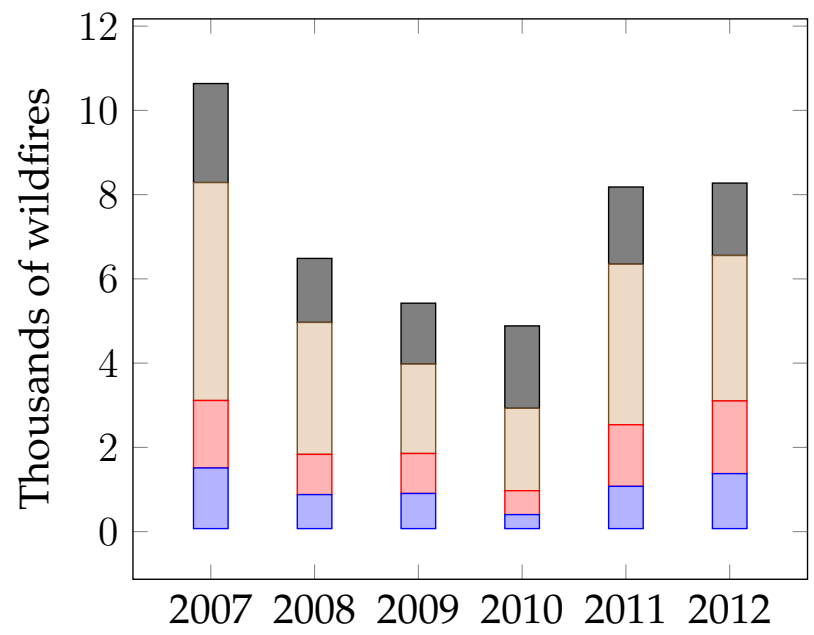

\section{$\square$ North $\square$ Centre $\square$ South $\square$ Islands}

Figure 4.2: Thousands of wildfires reported on the Italian territory, by year and by macroregion. The Northern macroregion includes: Emilia-Romagna, Friuli-Venezia Giulia, Liguria, Lombardy, Piedmont, Trentino-Alto Adige, Aosta Valley and Veneto $\left(120,260 \mathrm{~km}^{2}\right)$; the Central macroregion includes: Latium, The Marches, Tuscany and Umbria $\left(58,052 \mathrm{~km}^{2}\right)$; the Southern macroregion includes: Abruzzo, Basilicata, Calabria, Campania, Molise and Apulia $\left(72,223 \mathrm{~km}^{2}\right)$; the Island macroregion includes: Sicily and Sardinia $\left(49,801 \mathrm{~km}^{2}\right)$. Data sources: Legambiente, Dipartimento Nazionale della Protezione Civile, Ecosistema incendi 2011; Corpo Forestale dello Stato, Incendi boschivi 2008-2012. 


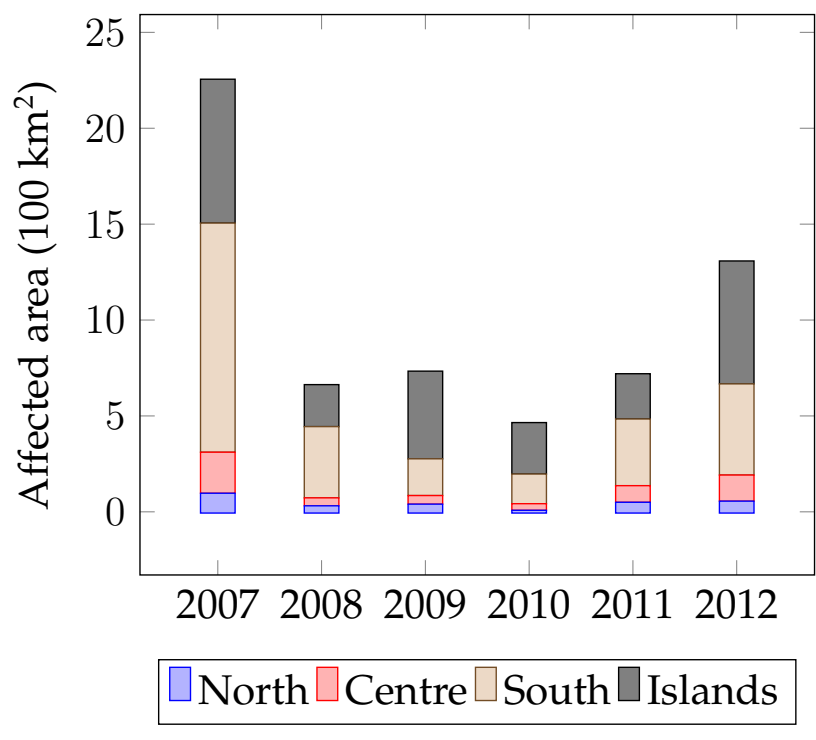

Figure 4.3: Hundreds of square kilometres affected by wildfires on the Italian territory, by year and by macroregion. See figure 4.2 for a definition of the macroregions. Data sources: Legambiente, Dipartimento Nazionale della Protezione Civile, Ecosistema incendi 2011; Corpo Forestale dello Stato, Incendi boschivi 2008-2012. 
switched to a new sistem of classification of causes for wildfires in order to standardise its practices with those of the European Union. As of 2012, the CFS distinguishes between "natural" (1.1 per cent), "unintentional" (16.1 per cent), "intentional" (67.3 per cent), "uncertain" (10.9 per cent) and "nondescript" (4.6 percent) wildfires (Incendi boschivi 2012 24). Since 2000, the CFS filed a total of 5029 charges for causing wildfires, with 164 resulting in arrest or remand (35). There are various motives which induce arsonists to commit crime. In 62 cases out of 164, they were shepherds renewing pastures or removing vegetation from areas adjacent to woodlands. Mental illness (pyromania) was found in 52 cases, 4 more cases were motivated by vandalism, and in 4 others a link with organised crime was shown (39).

To fight arson, in 2000, the Italian parliament passed a law which calls for the creation of municipal registers of land affected by wildfires. The 353/2000 law prohibits for 10 years activities such as building, hunting or shepherding in areas which have been affected by wildfires, with the aim of preventing economic and property speculation (Osservatorio Ambiente e Legalità, Ecomafia 2011 393-394). A 2011 survey by Legambiente evidenced that, while as many as 78 per cent of responding municipalities have instituted land registers, only 5 per cent fully comply with the law, which requires (among other activities) the register to be updated yearly, fire detection and prevention, and information campaigns for municipal employees and the wider population (Legambiente and Dipartimento Nazionale della Protezione Civile 8).

Law enforcement agencies and the State have important roles to play in the prevention, suppression and damage limitation of environmental crime. However, the only permanent victory in this battle can come from sensitising the population to the fact that forests and woodlands are a precious and irreplaceable part of Italy's natural and cultural heritage. To change harmful approaches to the landscape, it is therefore necessary to change the culture and to this effect, it is fundamental to engage with younger generations using suitable languages and narratives. The VerdeNero series includes titles specifically aimed at teenage readers such as Licia Troisi's fantasy I dannati di 
Malva (2011) and Giancarlo De Cataldo's Fuoco!. I have chosen to analyse the latter because it grapples with the topic of land use change whereas Troisi's novel deals with chemical pollution and environmental discrimination, themes I have already explored in my discussion of Saviano, Kai Zen and Wu Ming.

\subsubsection{Teenage Treehuggers and Adult Dolts}

Fuoco! differs from the novels I have discussed so far in at least two respects. The first is that its intended readership is young people, and the second is that environmental themes represent only a secondary aspect of the novel. De Cataldo's wrote Fuoco! with a young readership in mind and this becomes apparent even before the narrative begins. The novel's epigraph reads: "A Gabriele, il futuro è suo" [To Gabriele, the future is his] (De Cataldo, Fuoco! 5). Gabriele is the name of De Cataldo's young son. At the video presentation of the novel, De Cataldo confirmed this intention, declaring that young people represent for him hope for positive change (Presentazione Fuoco! De Cataldo). Fuoco!'s characters and language are clearly targeted at a teenaged readership, as well as its main themes: friendship and infatuation, teen angst and self-consciousness, the necessity to overcome the delusions of childhood, and cannabis (De Cataldo, Fuoco! 150, 13-14, 198, 19). Indeed, teenagers are Fuoco!'s heroes and heroines: they propel the action towards its positive ending, whereas adults are either moved by greed, or trapped by social and cultural entanglements which prevent them from seeing or reacting effectively to solve society's problems.

The novel's main character is $\mathrm{Lu}$, a troubled teenager who expresses his angst through recurring nightmares and uncontrolled bursts of violence, " $i$ punti fermi della sua esistenza negli ultimi mesi" [the pivotal elements of his existence during the past few months] (De Cataldo, Fuoco! 16, 107). Only when he meets Cecilia, the daughter of an entrepreneur with links to the Camorra, does he begin to outgrow his depressive tendencies and learn how to use his courage, strength and determination for good purposes. De Cataldo engages 
teenagers with a story that combines action and romance, and allows the author to show how kindness can trigger a personality change. In addition, Fuoco! puts teenagers centre stage, suggesting that their young age is no barrier to contributing positively to society and that, on the contrary, they are allowed a boldness which adults cannot afford. Finally, De Cataldo uses the appeal of his straightforward and action-packed story to reach out to his young readership on the issue of wildfires and warn them about organised crime.

Conversely, De Cataldo describes adults as flawed. For instance, Cecilia's father, Leonardo, highlights the risks of a criminal lifestyle. Leonardo cuts a tragicomical figure: his paternal love for his daughter somehow tempers his weaknesses and greed. A building entrepreneur with links to the Camorra, he falls out of favour with Don Carmelo, his Camorra boss, for trying to murder one of the boss' men. In his car, Leonardo reflects that he "[a]veva fatto il passo più lungo della gamba, e ora ne avrebbe pagate le conseguenze. Si era messo a sfidare i fetenti sul loro stesso terreno! Ma come? Ma perché? Per vanagloria? Per arroganza? Per..." [he had bitten off more than he could chew and now he would have to pay the consequences. He challenged the slimebags on their own turf! But how? But why? Because of vainglory? Because of arrogance? Because of...] (De Cataldo, Fuoco! 45). His mistake leaves him no choice but to try and escape Naples and Don Carmelo's wrath together with his unsuspecting daughter Cecilia, who is completely unaware of her father's connection with organised crime. But where to, since expatriation is not an option because they left their passports in Naples? While running in circles around Campania and Apulia in his panic, he ends up in Porto Meraviglioso. There, Leonardo considers giving himself up to the police but, eventually, he decides against it because his assets would be seized and his daughter would have to live a miserable life under police protection (68). Having ruled out surrender, he decides to become a turncoat and join Don Carmelo's arch-enemy Vittorio O'Verme. However, his new criminal allegiance proves equally ruinous for Leonardo, who becomes entangled in a web of extortion, conspiracies and crime (169). Leonardo's story shows the reader that collaborating with crime 
inexorably leads to downfall, and the novel ends with Leonardo being shot, presumably dead.

De Cataldo's authorial voice appears in the novel through another adult, the author surrogate character Guglielmo Carandini delle Mole. Just like De Cataldo, Carandini is a judge and, specifically, a "Procuratore Aggiunto" [Deputy Attorney General] (De Cataldo, Fuoco! 172). De Cataldo spends several pages illustrating Carandini's convictions which, when expressed in public, "provocavano immancabilmente lo sconcerto degli astanti" [infallibly baffled the bystanders] because they challenged commonly held assumptions in matter of justice (173). As a consequence, Carandini was tagged as a "pericoloso sovversivo, toga rossa e quant'altro" [dangerous subversive, leftwing magistrate and more] who believes that,

oggi la lotta alla criminalità organizzata non [va] condotta tanto nelle strade e nei vicoli polverosi del Sud, quanto nei santuari della finanza interna e internazionale, troppo sensibili al motto pecunia non olet e indifferenti rispetto alle origini di certe improvvise fortune sbucate dal nulla [the struggle against organised crime today should not be fought on the dusty streets and alleys of the South, but in the sanctuaries of national and international finance, too sensitive to the motto pecunia non olet and indifferent to the origins of some sudden fortunes which appear out of nowhere] (De Cataldo, Fuoco! 174-176) ${ }^{11}$

Here, De Cataldo expresses to a younger readership in an accessible language a concept recurrent in other works already analysed: whereas in the past criminal organisations attempted to militarily challenge the State, their strategy has mutated. Organised crime has learnt that it is much more profitable and less risky to infiltrate business, politics and finance, imposing there its brutal rules and its economic power. Thus, there is a battle to be fought against criminal

\footnotetext{
${ }^{11}$ Toga rossa: literally, red gown. A derogatory term, used by the Italian political right, which indicates judges who are perceived to lean politically to the left. Red is a colour commonly associated with communism and socialism, and the gown is the uniform of judges in Italy.
} 
power, not with weapons but through ethics, education and law-a battle that only the new generations can hope to win:

in loro, in questi ragazzi, risiedeva un'altra speranza. Quella di un mondo diverso, di un'Italia meno gretta e incarognita. La generazione a cui Carandini apparteneva aveva fallito. Bisognava farsi da parte, lasciare spazio ai giovani, ritirarsi dietro le quinte cercando di trasferire quel minimo di esperienza che permettesse ai sogni e alle utopie (i giovani ne hanno ancora, checché ne pensino settimanali e talk-show) di crescere e di svilupparsi senza cedere al fascino della violenza e delle scorciatoie prive di senso [in them, in these teenagers, another hope lived: that of a different world, of a less narrow-minded and corrupt Italy. Carandini's generation had failed. It was necessary to step aside, make room for the young, retreat behind the scenes while trying to transfer a minimum of experience that might allow dreams and utopias (which young people still hold, whatever the weekly magazines and the talk-shows might believe) to grow and develop without surrendering to the charms of violence and of senseless short cuts] (De Cataldo, Fuoco! 177).

Adults, explains Carandini, have failed and have to step aside, giving more power to young idealistic generations unconstrained by the limits which afflict adults. However, Carandini argues that adults possess a baggage of knowledge and experience which could help new generations to avoid the mistakes of the past and build a better future.

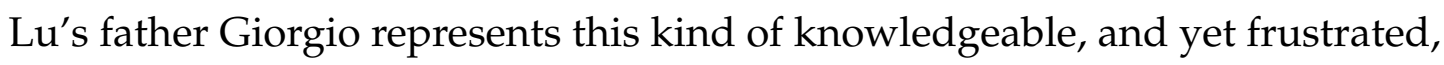
adult. Giorgio is a journalist who knows well the criminal dynamics causing, year after year, the loss of thousands of square kilometres of woodlands. However, he is powerless before the wildfires: his reportages are cut and edited to turn them into a "pastone senza senso infarcito di tutti i possibili e immaginabili luoghi comuni" [senseless blob stuffed with all possible and imaginable banalities]. In fact, Giorgio can see through the oversimplifications and the distortions of the media and in particular the oft-repeated notion 
that pyromaniacs are to be blamed for most fires. In his conversation with his unsophisticated brother, Giorgio points out that "fra tutti i pazzi, il piromane è il più raro" [among all madmen, the pyromaniac is the rarest] and that "se veramente ci fossero tutti questi piromani di cui si parla l'Italia intera sarebbe da rinchiudere in manicomio" [if all these supposed pyromaniacs really existed, the whole of Italy would have to be shut in an asylum] (De Cataldo, Fuoco! 137). The medical literature appears to support Giorgio's view. While it is true that many arsonists suffer from psychiatric disorders, pyromania remains an illdefined concept even among mental health professionals, a pathology which is diagnosed more often by police and fire personnel than by psychiatrists (J. L. Geller, McDermeit, and J. Brown; Lowenstein 193-194). In fact, Jeffrey L. Geller finds a high degree of misinformation among fire fighting personnel, insurance investigators, law enforcement and even mental health professionals about the topic of pyromania. Moreover, he claims, literature available to these professionals often provides "misleading and even inaccurate information about pyromania" (J. L. Geller, qtd. in Doley 800). Doley argues that the reason for such misinformation is that psychiatrists understand pyromania differently from non-specialists and that the latter tend to overestimate the incidence of the disorder (802). It has been already mentioned that, in the Incendi boschivi 2012 report, the CFS claims that 31 per cent of arsonists arrested between 2000 and 2012 were motivated by pyromania and behavioural disorders (Incendi boschivi 2012 35). So, while it may be true that a sizeable percentage of arsonists show symptoms of mental disease, conflating pyromania with behavioural disorder propagates misinformation. Moreover, it hides the fact that behavioural disorders do not preclude further motives, and De Cataldo makes this point very clearly in his novel.

In Fuoco!, Salvatore is Porto Meraviglioso's "matto del villaggio" [village idiot] (De Cataldo, Fuoco! 122). Salvatore intensely hates the dogs which populate the maquis around the town. When he is caught by the police with a demijohn full of petrol, apparently trying to light a fire with the intention of killing the animals, the authorities take Salvatore's account at face value (185). 
However, Giorgio points out to the authorities that Salvatore would be unable to "procurarsi una tanica, anzi, una damigiana piena di benzina! Qualcuno gli ha commissionato l'incendio" [obtain a jerrycan, no, a demijohn full of petrol! Someone commissioned him the arson] (190). Through Giorgio's and Carandini's insistence, it emerges that someone provided Salvatore with the petrol: "Salvatore cominciò a piagnucolare. «None, ca ce sacciu! Curu ha dittu che accussì accidia li cani, e mi desi la benzina... »" [Salvatore began to whine. «No, I don't know! That guy said that this way I'd kill the dogs, and he gave me the petrol...»]. (193). De Cataldo illustrates to his young readership how appearances can be deceiving and invites them to be wary of oversimplifications which attribute wildfires to so-called pyromaniacs, often convenient scapegoats used to cover the police's unwillingness to investigate into more nefarious activities.

Who is this "curu" Salvatore refers to? Who mandated Salvatore to commit arson, and who may be interested in destroying the woodland of Porto Meraviglioso? In addition, if targeting natural heritage is a deliberate plan, what are the reasons prompting the instigators? After Salvatore's interrogation, the authorities become puzzled: "Ma che senso ha? ... [Q]ua non si può certo edificare! È... È un atto di puro vandalismo!" [It makes no sense ... [I]t is certainly not possible to build here! It is... It is an act of pure vandalism!] (De Cataldo,Fuoco! 193). As a judge, De Cataldo is well-aware of the law $353 / 2000$ which prohibits economic activity in areas damaged by wildfire, but makes the point that this law fails, in some cases, to prevent crime. De Cataldo offers the solution to this riddle by switching to a different vantage point: an argument erupts between Leonardo and Petruzzo, Vittorio O'Verme's right-hand man. Challenged by Leonardo, Petruzzo explains the criminal strategy which demands the destruction of the Porto Meraviglioso's woodland:

Quando lo Stato rompe troppo i coglioni... Scusate, eh... Quando la Polizia alza troppo la testa... Beh, bisogna ricordargli che ci siamo anche noi. E che non siamo disposti a farci mettere sotto. Sono stato chiaro?! È un segnale! Voi state esagerando. E noi vi 
bruciamo i boschi. Voi fate i bravi guaglioni, e i boschi se ne restano al posto loro. Ve lo ricordate quando i siciliani mettevano le bombe ai monumenti? Beh, è la stessa identica cosa. Significa: statevene buoni, non esagerate, e non esagereremo neanche noi! [When the State becomes a pain in the arse... Excuse me... When the Police rears its head... Well, we have to remind them that we're here. And that we won't let them trample us. Is it clear?! It's a message! You're exaggerating. And we burn your woodlands. You behave like good boys, and we leave the woodlands alone. Do you remember when the Sicilians bombed the monuments? Well, it's the same thing. It means: behave, don't go overboard, and we won't go overboard, either!] (De Cataldo, Fuoco! 204).

De Cataldo's fictional thesis is that the Camorra is pursuing a strategy of deliberate destruction similar to the Mafia's in the early Nineties, aimed at forcing the State and civil society to acquiesce to their activities-a thesis De Cataldo is familiar with since writing Nelle mani giuste. In Fuoco!, De Cataldo appears to theorise that the hand of the Camorra and, worse, a terrorist strategy, may be behind some of the wildfires. Criminals are attempting to intimidate authorities and therefore obtain carte blanche to expand their influence and power.

Although an interesting proposition, this hypothesis leaves open some questions. The first is that intimidation does not work unless a claim for responsibility is made. The group "Falange armata" claimed the 1992-1993 attacks, but the bloodshed led to a reaction which eradicated Cosa Nostra's leadership. Modern organised crime pursues the diametrically different strategy of keeping out of the public eye, infiltrating business and politics rather than militarily confronting the State-therefore De Cataldo's claim that Fuoco! is a possible story seems rather unlikely. The second is that, according to CFS data, a definite link with organised crime could only be found in 4 cases out of 162 in 2012. A much greater number of intentional arsons are, rather more prosaically, caused by shepherds and farmers attempting to destroy vegetation. Suggesting 
that the hand of organised crime can be found behind a significant number of wildfires in the Southern regions appears to be an overstatement.

Ultimately, these discrepancies matter little: in an interview, De Cataldo declared that, whereas unfounded accusations can be impermissible in a court of law, a writer "può prendersi tutte le libertà di questo mondo. E immaginare scenari che sarebbe arduo, allo stato, provare compiutamente" [can be as free as he wishes and imagine scenarios which would be difficult for the State to prove conclusively] (Fraschini). Fuoco! is an uncomplicated story of teenagers, for teenagers, grappling with teenager themes. De Cataldo chose not to place environmental themes at its centre and instead left them at its margins so as to keep its young readers engaged without overburdening the story with elements that he perhaps saw as alien to teenagers' interests. However, although the environment is not as central to the plot as in literary writings targeted at a more mature readership, Fuoco! undoubtedly grapples with the problem of wildfires. The explicit declarations of the author (both within the text and outside of it) clearly reveal Fuoco!'s didactic aim beyond the desire to write for its intended audience. Even more importantly, the section "I fatti" provides a brief introduction to the phenomenon of the wildfires in Italy for those interested in distinguishing between reality and narrative license. While it is important to enhance the awareness of the general population regarding the environmental consequences of irresponsible behaviour, educating the younger generations appears to be a crucial task. The world-view of teenagers is very much a workin-progress whereas it is much harder to change deep-seated habits and views of older individuals, whose interest is often the protection of the status quo. Disparaging the inertia of the adult world, De Cataldo's novel invites young readers to not give in to fear and nihilism, encourages them to trust their instinct, and to face the challenges of evil and of becoming adults bravely. French surrealist author Robert Benayoun remarked that the "normal qualities of youth [are] naïveté, idealism, humour, hatred of tradition, erotomania, and a sense of injustice" (157). It is thus fundamental to engage with young people in terms which resonate with their idealism, iconoclasm and sense of injustice. 
In his novel Fuoco!, De Cataldo provides a positive and hopeful message about growing up, counterbalanced with an approachable (if at times exceedingly fanciful) introduction to ecocrime.

\subsection{Bloodied Cement Handprints: Gomorra}

Waste and cement represent two pillars of the Camorra's economy. We have seen in the previous chapter how Saviano describes the cycle of waste in $\mathrm{La}$ terra dei fuochi. Nowadays, waste trafficking provides perhaps a bigger source of income for the clans, but property speculation and illegal building have been staple activities of the criminal organisations for much longer and are therefore rooted deeper in the Camorra's ethos. Saviano dedicates no single chapter to the cycle of cement: instead, its stories and its people permeate Gomorra's entirety as if no boundary could hold back its tide. Ecomafia reports estimate the average yearly income from illegal building from 2008 to 2012 at 1.8 billion euro. However, this amount is likely an underestimate because organised crime potentially infiltrates public works worth several billion euros every year (Osservatorio Ambiente e Legalità, Ecomafia 2010]54; Ecomafia 2011 46; Ecomafia 2012 68; Ecomafia 2013 56). Just like the cycle of waste, the cycle of cement creates huge capital flows in the grey area between the legal and the illegal where the Camorra thrives: by engaging in apparently lawful activities, the clans turn substantial profits without running the risks associated with illegal activities. Investigators have only recently begun to probe the relationship between property speculation and organised crime, finding corruption, rigged building contracts and property speculation: compliant politicians favour the businesses of the Camorra which, in turn, funds the politicians' political campaign (Ecomafia 2013 229). Furthermore, the building industry provides relatively safe methods to launder money. Capital obtained through the underground economy can be injected into apparently legal enterprises (especially building companies or large retail stores) without arousing suspicion, thereby providing organised crime with "clean" money which can be safely reinvested. Especially in Campania, 
the Camorra finds fertile soil for its business due to a culture of silence, omertà, and administrative inattentiveness of civil servants-who, for personal gain, turn a blind eye to the abuse or, worse, actively conspire with organised crime by obstructing and delaying the action of the law enforcement agencies: since 1991, property speculation occurred in 81 per cent of Campanian town councils disbanded because of links to the Camorra, showing a definite link between corrupt politics and widespread illegality in the building industry (248-249).

\subsubsection{The System}

The Camorra looks like a perfectly oiled money-making apparatus: on the one hand it crushes flesh, habitats, life, freedom and law, while on the other hand it concentrates unimaginable wealth and power in the hands of its top executives. One way for the external observer to gauge the wealth available to the clans is to scrutinise the amount of property that the authorities have seized from them:

Soltanto i beni immobili sequestrati dalla DDA di Napoli nell'ultima manciata di anni ammontano a settecentocinquanta milioni di euro. Gli elenchi sono spaventosi. Solo per il procedimento del processo "Spartacus" avevano sequestrato centonovantanove fabbricati, cinquantadue terreni, quattordici società, dodici autovetture $\mathrm{e}$ tre imbarcazioni. Nel corso degli anni erano stati sequestrati a Schiavone e ai suoi fiduciari, in un procedimento del 1996, beni per quattrocentocinquanta miliardi, aziende, villini, terreni, fabbricati e automobili di grossa cilindrata [Just the real estate assets seized by the Naples DDA in the last few years amount to 750 million euros. The lists are frightening. In the Spartacus trial alone, 199 buildings, 52 pieces of property, 14 companies, 12 automobiles, and 3 boats were sequestered. Over the years, according to a 1996 trial, Schiavone and his trusted men have seen the seizure of assets worth 450 billion euros: companies, villas, lands, buildings, and automobiles with 
powerful engines] (Saviano 229$) \cdot{ }^{12}$

These are enormous losses which, Saviano notes, would have crushed any other economic group. However, the Casalesi have been able to take them without flinching, proving that the amount of wealth they control must by far exceed what the authorities have been able to seize. Saviano estimates that the capital available to the Casalesi is worth 30 billion euro (214).

How could a single clan of the Camorra accumulate such unimaginable wealth? One of the most revolutionary concepts that Saviano introduces in Gomorra is the reframing of Neapolitan clans not as pathogens extraneous to the capitalist system and bent on its destruction, but as cancerous cells propounding an extreme version of it: a disastrous, exponential growth at the expense of civil society and ecosystems. "Camorra", Saviano explains, is

una parola inesistente, da sbirro. Usata dai magistrati e dai giornalisti, dagli sceneggiatori. È una parola che fa sorridere gli affiliati, un'indicazione generica, un termine da studiosi, relegato alla dimensione storica. Il termine con cui si definiscono gli appartenenti a un clan è Sistema ... Un termine eloquente, un meccanismo piuttosto che una struttura. L'organizzazione criminale coincide direttamente con l'economia, la dialettica commerciale è l'ossatura del clan [a nonexistent word, a term of contempt used by narcs and judges, journalists and scriptwriters; it's a generic indication, a scholarly term, relegated to history-a name that makes Camorristi smile. The word clans members use is System ... an eloquent term, a mechanism rather than a structure. The criminal organisation coincides directly with the economy, and the dialectic commerce is the framework of the clans] (Saviano 48 ).

Organised crime is often perceived as a rigid structure governed by a strong man. This may have been true for Salvatore Riina's Cosa Nostra but it is

\footnotetext{
${ }^{12}$ DDA: Direzione Distrettuale Antimafia [District Anti-Mafia Directorate]. The DDA is an emanation of a district capital's Power of Attorney specialised in investigating organised crime.
} 
not true for the Camorra: unlike the rigidly hyerarchical Sicilian Mafia, the entrepreneurial ethos, protean nature and adaptability of the Neapolitan clans belie their power. Carmine Schiavone believed that the Camorra had to use the State rather than opposing it: "[n]oi vivevamo con lo Stato. Per noi lo Stato doveva esistere e doveva essere quello Stato che c'era ... Se qualcuno nello Stato ci faceva ostruzionismo, ne trovavamo un altro disposto a favorirci. Se era un politico non lo votavamo, se era uno delle istituzioni si trovava il metodo per raggirare" [[w]e lived with the state. For us the state had to exist and it had to be that state ... If a state figure stonewalled us, we would find someone else who was willing to help us. If it was a politician, we wouldn't vote for him, and if it was an institutional figure, we would find a way to swindle him]. The Casalesi envisioned their criminal organisation as a parasite rather than an enemy of the State, adopting ruthless free-market rules to conduct business "con, attraverso e senza lo Stato" [with, through or without the state] (Saviano 209).

\section{An Italian-Style American Dream}

Gomorra is saturated with stories detailing the entrepreneurial success of members of the various Campanian "systems" - a success invariably rooted in the power of cement: "[i]l potere dei clan rimaneva il potere del cemento. Era sui cantieri che sentivo fisicamente, nelle budella, tutta la loro potenza" [the clans' power remained the power of cement. It was at the construction sites that I could feel—physically, in my gut—all their might] (Saviano 231). While the Ecomafia reports confirm that illegal cement constitutes one of organised crime's main industries, Saviano argues that the dynamics of the building industry provide the basis of all power in the Italian South:

Non esiste impero economico nato nel mezzogiorno che non veda il passaggio nelle costruzioni: gare d'appalto, appalti, cave, cemento, inerti, malta, mattoni, impalcature, operai. L'armamentario dell'imprenditore italiano è questo. L'imprenditore italiano che non ha i piedi del suo impero nel cemento non ha speranza alcuna 
[Every economic empire that arises in the south passes through the construction business: bids, contracts, quarries, cement, components, bricks, scaffolding, workers. These are the Italian businessman's armaments. If his empire's feet are not set in cement he hasn't got a chance] (Osservatorio Ambiente e Legalità, Ecomafia 2013 249; Saviano 235).

Lawlessness provides an opportunity for the accumulation of capital to the many entrepreneurs devoid of ethical concerns keen on joining the fray: "a sud possono ancora nascere gli imperi, le maglie dell'economia si possono forzare e l'equilibrio dell'accumulazione originaria non è stato ancora completato" [[e]mpires can still be born in the south, the links of the economy can be strengthened, and the balance of the original accumulation is still incomplete]. In this way, Italian construction entrepreneurs have created a grotesque imitation of the American dream, though with noticeable differences. First, American and Italian capitalists differ in their relationship with their success: "negli USA, quando un imprenditore riesce a divenire riferimento finanziario ... convoca analisti e giovani economisti per mostrare la propria qualità economica, e svelare le strade battute per la vittoria sul mercato. Qui silenzio. E il danaro è solo danaro" [[i]n ... the USA, when a businessman becomes a top name in the financial world ... he summons analysts and young economists to show off his skills and discloses the route he took to victory. Here silence. Money is only money] (Saviano 238-239). Second, whereas the American dream is (at least purportedly) about virtues such as hard work, creativity and risk-taking, money becomes a self-referential value in the case of Italian building entrepreneurs and eschewing the spotlights becomes for them necessary so as to protect their actions from ethical and in some cases legal enquiry.

Like Pasolini's "Io so" article, Gomorra lifts the lid on a dark reality whose existence many suspected, but few could prove-and even fewer wanted exposed. Capital begets capital: the vastness of the Camorra's assets guarantee easy access to lending. In addition, the Italian financial sector has been historically friendly towards construction businesses. Italian banks, 
Saviano explains, "sembrano edificate per i costruttori ... Ricerca, laboratorio, agricoltura, artigianato, i direttori di banca li immaginano come territori vaporosi, iperurani senza presenza di gravità. Stanze, piani, piastrelle, prese del telefono e della corrente, queste le uniche concretezze che riconoscono" [seem made for the builders ... Their directors think that research, laboratories, agriculture, and crafts are like vaporous terrain, ethereal, and devoid of gravity. Rooms, floors, tiles, phone jacks and electrical outlets-these are the only forms of concreteness they recognize] (236). Innovation, creativity, research and industry entail risks, whereas cement guarantees a return of investment for banks and investors alike. Cement provides an enormous potential for profit to those who have the right connections and the right mindset and it is therefore unsurprising to observe that property speculation is the industry of choice of many camorristi, bringing millionaire, risk-free profits to the coffers of the clans.

This is not to say that the Camorra's entrepreneurs lack business sense. On the contrary, some parts of Gomorra ought to be part of the curriculum of MBA courses as they describe the workings of some of the most successful businesses in Italy and the world: something Italians could be proud of, if said businesses were not engaged in some of the most repugnant trades imaginable, like "[c]emento e narcotraffico, racket, trasporti, rifiuti e monopolio nel commercio e nelle imposizioni di forniture" [[c]ement, drugs, rackets, transportation, waste management, commercial monopolies and specified suppliers] (Saviano 214). The modern Camorra has been able to turn the extortion racket into a service which its clients welcome as a way to dominate over their business competitors. In fact, given the economic power of the clans, "[p]agare un mensile al clan ... può significare anche ricevere protezione economica con le banche, camion in orario, agenti commerciali rispettati" [[y]our monthly payments fund clan operations, but they also earn you economic protection with the banks, punctual deliveries, and respect for your sales representatives] (215). Thus, the Camorra extends its power above and beyond simple traditional criminal activities, beyond property speculation and, like metastases from a cancerous growth, invades and monopolises all business areas, blurring the line between legal and 
illegal, between business and crime:

oltre al cemento, le navi dei consorzi distribuivano armi ai paesi mediorientali con embargo. Questo secondo livello di commercio permetteva di abbattere i costi del livello legale. I clan Casalesi guadagnavano in ogni passaggio dell'economia dell'edilizia. Fornendo cemento, fornendo ditte in subappalto per la costruzione e ricevendo una tangente sui grossi affari. Tangente che risultava essere il punto di partenza, poiché senza versarla, le loro ditte economiche ed efficienti non avrebbero lavorato, e nessun'altra ditta avrebbe potuto farlo senza danno alcuno e a buon mercato [their ships carried not only cement, but also distributed arms to Middle Eastern countries under embargo. This second level of commerce allowed them to beat out the legal prices. The Casalesi clans made money at every step of the way; they supplied cement and subcontractors, receiving bribes on big deals. Bribes were really just the beginning, since their efficient and economical companies would not work without them, and no other company could do the work for a good price and without being punished] (Saviano 214).

The most successful capitalists are those who can satisfy the demands of the market at the lowest price. Likewise, while the guns lie quiet, the Camorra earns its staggering profits by reducing the price of the services it offers and inflicting huge external costs on third parties (whether human or non-human) who have no voice and therefore no power. This is true whether the business is waste disposal or building: "stakeholders" offer cheaper prices because they bypass safe disposal practices for dangerous waste whereas illegal builders can build cheaper because they forgo authorisations, have access to capital and to cheaper materials and to a cheaper workforce. 


\section{Power and Death, Statistics and Narrative}

Antonio Scurati notices that, in Gomorra, Saviano positions himself as an observer of events that he may or may not have witnessed but might have learnt through police reports, newspapers and documents. Through this narrative technique, Scurati argues, Saviano personally guarantees for the truthfulness of his narration ("L'epica è rediviva e lotta insieme a noil"). More importantly, framing impersonal reports as narrative imbues them with a humanity which reaches the heart and mind of the reader and can leave none indifferent. One instance where Saviano becomes the subject of his own narration is when he relates his time as a construction worker (231). This experience provides a starting point to highlight the atrocious conditions which workers are exposed to in the Campanian construction yards:

[1]a velocità di costruzioni, la necessità di risparmiare su ogni tipo di sicurezza e su ogni rispetto d'orario. Turni disumani nove-dodici ore al giorno compreso sabato e domenica. Cento euro a settimana la paga con lo straordinario notturno e domenicale di cinquanta euro ogni dieci ore. I più giovani se ne fanno anche quindici. Magari tirando coca [ $\mathrm{t}] \mathrm{he}$ speed of construction, the need to save on every form of safety and on every sort of schedule. Inhuman shifts, nine, twelve hours a day, Saturdays and Sundays included. A hundred euros a week, plus 50 more for every ten hours of Sunday or evening overtime. The younger ones even do fifteen hours, maybe by snorting cocaine] (Saviano 237-238).

Exceedingly long working hours and lack of basic safety practices, all in the name of cutting costs and increasing profit, provide the preconditions for tragedy. Indeed, in the "system", profit acquires such a consuming preeminence that human life itself becomes disposable, and death a neglected externality. Workplace deaths, Saviano reports, are often disguised as driving accidents, while casualties are abandoned to their fate. This results in the dehumanisation of workers, who realise that their team mates might suddenly become their 
executioners if something were to happen to them: "[c]hi ti è a fianco potrebbe essere il tuo boia, $\mathrm{o}$ tu il suo. Non ti farà soffrire, ma sarà colui che ti lascerà crepare da solo su un marciapiede o ti darà fuoco in un'auto" [[t]he person next to you could be your executioner, or you his. He won't make you suffer, but he'll leave you to die alone on the sidewalk or burn you in a car] (Saviano 238). As previously noted, INAIL estimates thousands of casualties in construction yards yearly. However, this is likely to be an underestimate: accidents in illegal building yards often go unreported because sending a casualty to a hospital would cause a police investigation to be launched.

Joseph Stalin is reported to have said that, "A single death is a tragedy; a million deaths is a statistic", highlighting the fact that statistics lack the emotive strength which anecdotes often possess. One of these single deaths, that of Francesco Iacomino, inspires one of Gomorra's angriest and most poignant paragraphs. Iacomino was a thirty-three year-old building worker left to die after falling from scaffolding because everyone in the building yard ran away after the accident: "avevano lasciato il corpo a metà strada, ancora vivo, mentre sputava sangue dai polmoni" [they left him lying in the street, still alive, spitting blood from his lungs] (Saviano 232). It is the emotional power which the personal tragedy of Iacomino's death generates that precipitates Saviano's realisation that the power of the word could be used to contrast the power of the Camorra and his subsequent determination to write Gomorra. Gomorra draws its narrative impact from turning statistics into faces, giving names to anonymous reports,

fare i nomi, a uno a uno, indicare i visi, spogliare i corpi dei reati e renderli elementi dell'architettura dell'autorità ... inseguire come porci da tartufo le dinamiche del reale, l'affermazione dei poteri, senza metafore, senza mediazioni, con la sola lama della scrittura [a place where it was still possible to reflect without shame on the possibility of the word. The possibility of writing about the mechanisms of power, beyond the stories and details. To reflect on whether it is still possible to name names, one by one, to point out the 
faces, strip the bodies of their crimes, and reveal them as elements of the architecture of authority. To reflect on whether it is still possible to sniff out, like truffle pigs, the dynamics of the real, the affirmation of powers, without metaphors, without mediation, with nothing but the cutting edge of the word] (Saviano 233).

Through this power, Gomorra not only challenges the Neapolitan "systems" but also their manifestations in each of its readers through suggesting that every citizen, every reader, every voter, every consumer can choose not to submit to the Camorra.

Saviano writes that the goal of every Camorrista is to "[e]ssere il centro di ogni azione, il centro del potere. Usare tutto come mezzo e se stessi come fine" [ $[\mathrm{t}] \mathrm{o}$ be the center of every action, the center of power. To use everything as a means and themselves as an end] (Saviano 127). Similarly, Inner Party member O'Brien argues in Nineteen Eighty-four that "[p]ower is not a means; it is an end ... The object of power is power" (Orwell 276). As readers and as citizens we stand at the junction between two great forces: the enlightening potential of writing and the Machiavellian might of virtually unlimited capital unrestricted by law and ethics, where profit is a means to power, and power the only, selfreferential, end.

\subsubsection{The Materiality of Cement}

In Gomorra, language and cement intersect: on the one hand, the Camorra uses the language of architecture to assert its domination, and, on the other hand, Saviano uses the language of literature to convey the reality of cement. In "La terra dei fuochi", the author evokes synaesthetic disgust by overwhelming the reader with toxic sensory inputs and likewise, when talking about cement, Saviano binds his narrative to the material dimension:

[c]ome qualcuno che guardando Vermeer pensasse a chi ha mescolato i colori, tirato la tela coi legni, assemblato gli orecchini di perle, piuttosto che contemplare il ritratto. Una vera perversione. Non 
riesco proprio a scordarmi come funziona il ciclo del cemento quando vedo una rampa di scale, e non mi distrae da come si mettono in torre le impalcature il vedere una verticale di finestre [like someone in front of a Vermeer painting who, instead of contemplating the portrait, thinks about who mixed the colors, stretched the canvas, and made the pearl earrings. A real perversion. When I see a flight of stairs, I simply cannot forget how the cement cycle works, and a wall of windows doesn't keep me from thinking how the scaffolding was put up] (Saviano 234-235).

Through this "oblique" point of view which penetrates aesthetics while remaining firmly rooted in materiality, he recreates the physical and oppressive slow violence of the Camorra's cement in the reader's mind through his trademark "overloaded" narrative (see section 3.1.2). Undistracted by theorising, Saviano narrates the visible, the auditory, the tactile, the olfactory:

[c]redo che in Qatar 1'odore di petrolio e benzina rimandi a sensazioni e sapori che sanno di residenze immense, occhiali da sole e limousine. Lo stesso odore acido del carbonfossile, a Minsk, credo rimandi a facce scure, fughe di gas, e città affumicate mentre in Belgio rimanda all'odore d'aglio degli italiani e alla cipolla dei maghrebini. Lo stesso accade col cemento per l'Italia, per il mezzogiorno. Il cemento. Petrolio del sud. Tutto nasce dal cemento. Non esiste impero economico nato nel mezzogiorno che non veda il passaggio nelle costruzioni [I believe that in Qatar the smell of petroleum and gas evokes sensations and flavors of mansions, sunglasses, and limousines. The same acid smell of fossil fuel in Minsk evokes dark faces, gas leaks, and smoking cities, whereas in Belgium it calls up the garlic Italians use and the onions of the North Africans. The same thing happens with cement in the south of Italy. Cement. The petroleum of the south. Cement gives birth to everything. Every economic empire that arises in the south passes through the construction business] (Saviano 235). 
By purposely saturating his narrative with smells and sights, and at the same time revealing the hidden significance of these sensory inputs, Saviano reminds readers of the indissoluble, primeval link between business, Camorra and cement in Italy.

\section{Delusions of Grandeur}

Francis Ford Coppola's 1972 film The Godfather, stars Marlon Brando as Vito Corleone, the elderly and charismatic leader of a powerful Italo-American Mafia family. The popularity of The Godfather introduced the Mafia to an international audience, so much so that organised crime bosses are understood in folklore as being as ruthless, but as honourable and as charismatic, as Vito Corleone. Saviano's Gomorra dispels this outdated understanding of organised crime on at least two grounds: first, the nature of the Neapolitan Camorra is profoundly different from that of traditional American and Sicilian Mafias. And second, modern organised crime has abandoned any pretensions to honour and charisma and embraced the pragmatic ways of business. On the contrary, Saviano writes, "[n]on è il cinema a scrutare il mondo criminale per raccoglierne i comportamenti più interessanti. Accade esattamente il contrario" [[i]t's not the movie world that scans the criminal world for the most interesting behavior. The exact opposite is true] (272-273). In an effort to acquire a charisma they are devoid of, criminals ape their Hollywoodian counterparts, "gli occhiali scuri, i gessati, le parole ieratiche" [dark glasses, pin-striped suits, and solemn speech], identifying so much with fictional criminals so as to imitate "le scelte tecniche come l'impugnatura della pistola e il modo di sparare" [technical choices such as the way you handle or shoot a gun] (274). The assimilation of Hollywoodian tropes like clothing, terms and gestures constitute only the surface of the influence that American cinema exerts upon power-hungry criminals eager to display their aggression and status over peers and competitors.

In particular, because of its physical qualities, cement represents a privileged pathway through which the Camorra asserts its power, its vanity and its hierarchy but, most importantly, its anarcho-capitalist credo. The Neapolitan 
countryside, Saviano writes, is littered with villas whose architectural excesses are directly proportional to the power wielded by their owners:

[1]e ville più imponenti dei costruttori e dei proprietari terrieri tracciano il modello per i villini degli impiegati e commercianti. Se le prime troneggiano su quattro colonnati dorici di cemento armato, le seconde ne avranno due e le colonne saranno alte la metà. Il gioco all'imitazione fa sì che il territorio si dissemini di agglomerati di ville che gareggiano in imponenza, complessità e inviolabilità in una ricerca di stranezze e singolarità [[t]he most imposing villas, belonging to contractors and landowners, provide the inspiration for office workers' and the shopkeepers' houses. If the former is enthroned with four Doric columns in reinforced concrete, the latter will be adorned with two columns half their size. This imitation game has filled the area with villas competing to be the most impressive, complicated, and impregnable, mansions striving for eccentricity and uniqueness] (266).

If the villas of the top executives provide a template for the cottages of the middle managers, the mansions of the bosses rise unequalled among the rest. Walter Schiavone, brother of notorious boss Francesco Schiavone, had a replica of Tony Montana's estate in the 1983 film Scarface built in Casal di Principe:

[1]a villa appariva imponente, luminosa, la facciata incuteva la stessa soggezione che si prova dinanzi a un monumento. Le colonne sorreggevano due piani con timpani di diversa grandezza organizzati in struttura verticale decrescente, con al centro un semicerchio mozzato. L'entrata era un delirio architettonico, due enormi scalinate si arrampicavano come due ali di marmo al primo piano che si affacciava a balconata sul salone sottostante. L'atrio era identico a quello di Tony Montana. C'era anche il ballatoio con un'entrata centrale allo studio, lo stesso dove si conclude tra piogge di proiettili Scarface [the villa was stately and luminous, and the monumental 
facade awe-inspiring. Columns supported a double pediment with a cropped semicircle in the center. The front hall was an architectural delirium: two enormous staircases, like marble wings, soaring up to the second-floor balcony, which looked onto the large hall below. Just like Tony Montana's. There was even a study off the balcony, just as in the final scene of Scarface, which ends in a torrent of bullets] (Saviano 268).

As he penetrates Walter Schiavone's deserted Hollywoodian villa, he contrasts its past opulence with the details of the boss' arrest. Many Camorristi, like "samurai liberisti" [samurai liberalists], aspire to a violent death (Saviano 129). Perhaps, Walter Schiavone fantasised about dying heroically like Tony Montana-boisterous, impervious to pain, facing dozens of foes, holding his rifle in his hands-but reality turned out to be rather more prosaic. Walter Schiavone was, Saviano reports, arrested in his own Hollywoodian home "mentre tentava di scavalcare il muro [di cinta]. Lo stesso che aveva fatto costruire per rendere impenetrabile la sua villa gli impedì di scappare con agilità. Acciuffato come un ladruncolo che sgambetta cercando appigli su una parete liscia" [as he tried to scale the [surrounding] wall. The same wall he had built to make his villa impregnable now prevented his quick escape. Nabbed like a petty thief flailing about in search of a hold on a smooth wall] (271). A pathetic end for a Tony Montana-would-be and a multimillionaire boss.

Saviano highlights a strong link between power, vanity and downfall through his collection of stories of notorious gangsters. Indeed, Walter Schiavone's humiliating capture is echoed in the death of Immacolata Capone. Immacolata began her career as a "dama di compagnia" [lad[y] in waiting] of Anna Mazza, one of the most powerful women of the Camorra, but soon distinguished herself thanks to her authoritativeness and her flair for business. (Saviano 160). Immacolata came to power when Anna Mazza's clan, the Moccia, was experiencing a crisis: "Immacolata Capone fu l'imprenditrice capace di riportare le ditte dei Moccia a conquistare nuovamente la leadership nel campo dell'edilizia. A sua disposizione vi era la ditta MOTRER, una delle imprese 
più importanti nel campo del movimento terra del mezzogiorno italiano" [Immacolata Capone led the Moccia family companies back to the top of the building trade. In this she had the cooperation of MOTRER, one of the most important names in earthmoving in southern Italy]. However, as with many Camorra stories, Immacolata's rise to power was interrupted violently when she was "uccisa nel marzo 2004 a Sant'Antimo ... Immacolata entrò in una polleria, ma non fece in tempo a rifugiarsi dietro al bancone. La raggiunsero e posarono la canna della pistola dietro la nuca. Due colpi secchi" [killed in March 2004 in Sant'Antimo, her companion's town ... She went into a poultry shop, but the killers got to her before she could take cover behind the counter. Two shots in the nape of the neck] (162). This episode bears striking similarities with Simona Vinci's Candida, also a businesswoman murdered (ironically) in a butcher's shop. Their names match (the names Immacolata and Candida both mean "spotless") but, most importantly, both women belong to powerful Camorra families and are involved in the building industry. It is therefore likely that Vinci used Immacolata as a template for her Candida. However, whereas Vinci focuses on Candida's death, Saviano's readers obtains a more intimate point of view on Immacolata's life and her need to build a Hollywoodian outward image projecting assertiveness and aggression. Immacolata, writes Saviano, travelled with two women bodyguards who followed her in a fluorescent yellow Smart car:

[u]na aveva una maglietta dello stesso colore dell'auto, mentre la donna al volante aveva la montatura degli occhiali da sole gialla. Un giallo che non poteva essere stato scelto per caso, né tantomeno indossato per una coincidenza. Era uno dei tocchi di professionalità. La stessa tonalità di giallo della tuta da motociclista che Uma Thurman indossa in Kill Bill di Quentin Tarantino, un film dove per la prima volta donne sono protagoniste criminali di prim'ordine [[t]he driver had on yellow sunglasses and the other a bright yellow T-shirt. A yellow that could not have been chosen by chance, a combination that could not have been a mere coincidence. A professional touch. 
The same yellow as Uma Thurman's motorcycle outfit in Kill Bill, the Quentin Tarantino film in which for the first time women are first-rate criminal stars] (161).

By wearing The Bride's shocking yellow attire, Immacolata and her female bodyguards enact their fantasies of revenge against their enemies. The references to Kill Bill would have been especially poignant for Immacolata, whose husband, Giorgio Salierno, had been murdered a few months before her death. The American action film characters which Walter Schiavone and Immacolata Capone emulate are criminal anti-heroes who resort to extreme violence to obtain wealth, power and revenge. For the aberrant personalities of the Camorra, Saviano comments, "[i]l cinema, soprattutto quello americano, non è visto come il territorio lontano dove l'aberrazione accade, non come il luogo dove l'impossibile si realizza, ma anzi come la vicinanza più prossima" [[movies, especially American movies, are not distant lands where aberrations occur or the impossible happens, but places very close to home] (275). But, ironically, the slow violence that environmental criminals commit is more real than the fictional fast violence of their Hollywood idols.

In addition to narrating the material nature of cement, in Gomorra, Saviano identifies the connections between language and matter where the word becomes cement and cement is the word of criminal power: he perceives the semantic power of cement and the Camorra's attempt to intimidate civil society through the physical display of its power. However, Gomorra's author, immersed as he is in the reality of the Camorra's empire, refuses to engage in a feigned objectivity: he is not as interested in telling the truth as in empowering his readers through his sensuous and ironic narrative which deconstructs the language of power, revealing the pathetic side of the Camorra's architecture of aggression. The Bride and Tony Montana are superhuman action characters who challenge both human laws and physical laws in their quest for power and revenge. Although criminal minds may be able to evade the rule of law for a limited time, Gomorra reveals how reality crushes their inflated egomania under a wall that is too high to be climbed and under a few grams of lead travelling at 
supersonic speed. In so doing, Saviano reveals the undeniable human weakness of even the most powerful boss, and thus foils the image-building efforts of the new Camorra, which seeks to find recruits by selling glamorous dreams of power and domination.

\section{Alchemies of Waste and Cement}

Saviano presents the cycles of cement and waste as complementary dimensions of the Camorra's power: whereas toxic waste is invisible, widespread and penetrating, cement is apparent, solid, immovable. As a consequence, the builder and the waste dealer operate under two seemingly opposed paradigms: " $[u]$ n costruttore vede lo spazio vuoto come qualcosa da riempire, cerca di mettere il pieno nel vuoto; gli stakeholder pensano invece a come trovare il vuoto nel pieno" [[a] builder sees empty space as something to be filled annd tries to occuppy the void; a stakeholder looks for empty space in what is already full] (Saviano 320). And yet, the two realities are profoundly interdependent in the Camorra's business plan and, like an alchemist transmutes base metals into gold, the Camorra turns waste into cement, and cement into gold. Indeed, one of the most profitable ways to dispose of dangerous waste is to mix it with cement: "lo smaltimento occultato nel cemento è divenuta la forza che permette alle imprese di presentarsi alle gare d'appalto con prezzi da manodopera cinese. Ora garage, pareti e pianerottoli hanno nel loro petto i veleni" [[c]ompanies connected to the clans use cement to hide waste, which is what allows them to come in with bids as low as if they were using Chinese labor. Now garages, walls, and stair landings are permeated by poison] (236-237). This strategy allows the waste dealers to earn money for disposal while at the same time providing unethical builders with cheap construction materials through which they can undercut their opponents' prices. Waste and cement turn into the gold of public and private contracts while homes, roads, schools and aqueducts-but ultimately bodies-become repositories of toxic waste.

Not only does the Camorra build with waste: it builds upon it. In the "Land of Fires", the Camorra profits even on saturated landfills: 
[n]on lontano dai fuochi, c'erano una serie di villette poggiate tutte su una enorme $x$ di cemento armato. Erano case adagiate su discariche chiuse. Discariche abusive che - dopo esser state utilizzate sino all'orlo, dopo aver bruciato tutto ciò che poteva essere bruciato - si erano esaurite. Colme sino a esplodere. I clan erano riusciti a riconvertirle in terreni edificabili ... E così avevano tirato su graziosi agglomerati di villette. Il terreno però non dava affidabilità, avrebbero potuto esserci smottamenti, improvvise voragini, e così maglie di cemento armato strutturate come resistenti $x$ di rinforzo rendevano sicure le abitazioni. Villette vendute a basso prezzo, seppure tutti sapevano che si reggevano su tonnellate di rifiuti. Impiegati, pensionati, operai, di fronte alla possibilità di avere una villa non andavano a guardare nella bocca del terreno su cui posavano i pilastri delle loro case [[n]ot far from the fires was a series of houses, each one sitting on an enormous $X$ of reinforced concrete. Homes resting on closed landfills and unauthorized dumps, their potential exhausted now that they'd been filled to the point of exploding and everything combustible had been burned. Yet the clans managed to reconvert them to building zones ... And so they built charming clusters of small villas. The terrain was unstable, however; landslides could occur and chasms suddenly open, so a fretwork of reinforced concrete propped up the dwellings, securing them. The houses were affordable; everyone knew they were standing on tons of trash. But given the chance to own their own home, office clerks, factory workers, and retirees don't look a gift horse in the mouth] (327-328).

As uncanny as these homes appear, they offer valuable insight into the relationship between the ideology of perpetual growth and the global ecosystem, as well as into the denial of its actors: blinded by the short-term prospect of achieving easy material success, individuals and nations ignore the consequences of creating and inhabiting a toxic space. 
The prefix eco- found in terms such as "ecology" and "ecosystem" derives from the Greek oîkos, meaning home or household. Because the current form of capitalism attributes no value to (and therefore corrodes) natural processes which sustain life, several ecological indicators show a rapid degradation of systems which support life as we know it. Pollution is rapidly accumulating in the atmosphere, the hydrosphere and on the surface of the planet, that is, above, below and around us. A recent survey of pollution in Europe found extreme levels of contamination in all marine habitats, while another expedition found pollutants as far as the Amudsen Sea around Antarctica (Pham et al.; Barnes, Walters, and Gonçalves). The Northern Pacific is home to the so-called Great Garbage Patch, an enormous area where the North Pacific gyre concentrates micro- and macro-plastics, pesticides and chemical sludge, including mercury, lead and dioxins (Rios et al.). Anthropogenic ozone-destroying chemicals and greenhouse gases have been diffusing in the atmosphere, and litter desecrates even Mount Everest's lofty heights. Stacy Alaimo writes in her Bodily Natures about the porosity of bodies and about the delusion of the elsewhere. The toxins which consumerist lifestyles necessarily produce cannot be confined elsewhere because, in this deeply interconnected world, there is no elsewhere at all. These pretty Hollywoodian cottages, walls stuffed with toxins and floating on a lake of burnt waste, represent a fitting metaphor for a world dominated by a global growth-fetishing economy and its necessary extension: the Camorra's extreme laissez-faire capitalism.

\subsection{Conclusion}

The Ecomafia reports and other sources denounce extremely pressing issues such as Southern Italy's wildfires which consume thousands of square kilometres of Mediterranean maquis every year, or illegal building which devours some of the most beautifully diverse ecosystems in Italy. The authorities have reported limited success in extirpating environmental crime and citizen activism undoubtedly has a role to play in limiting loss of ecosystems due to 
the often gratuitous expansion of artificial spaces. Future trends of expanding population and consumption also determine increasing pressures on ecosystems, necessitating stronger legal frameworks and environmental protection. However, activists would do well to avoid despair: there have indeed been victories for conservation in the last half-century which have taken place largely away from the public eye. Some may be emotionally attached to particular ecosystems and worried about their increasing anthropisation, but the reality is that forested areas have expanded dramatically since the 1960s, occupying land previously employed in pre-industrial rural practices. This said, the themes of property speculation and illegal construction have held a dominant position within contemporary Italian environmental narrative and cinema. There are multiple reasons for this thematic preference. First, cement and deforestation modify the landscape more conspicuously than other forms of ecological damage, do so very rapidly and in a way that is difficult to deny. And second, shelter is a basic human need and housing is the primary interface between humans and the landscape, contributing to turning it into a focus for humanists.

The three literary works of twenty-first century Italian environmental narrative discussed in this chapter provide different perspectives on the dynamics of land use change, including the cycle of cement, and its causes. Among the three, Fuoco! particularly stands out in that it is directed at a young readership. Whereas an adult reader may find its approach to environmental crime and wildfires naïve and perhaps trite, its structure, its themes and its narrative mechanisms are peculiarly suited to engage with teenagers. In Fuoco!, De Cataldo uses themes such as infatuation, wicked criminals, helpless fathers and resourceful teenagers to introduce the issues of wildfires, Camorra, and media misrepresentation. These themes are engineered to "seduce" teenagers into the story and provide them with tools to face the challenge of understanding and accessing the world of the adults without overburdening the narration. Probably due to the author's fame, Fuoco! has been one of the best-selling VerdeNero books. Gomorra has been an even bigger literary success, selling millions of copies in Italy and abroad. Gomorra has probably done more 
than any other literary work to arouse public interest in the phenomenon of the Camorra and to change readers' views on it. The forcefulness of Gomorra's narrative comes from Saviano the character/narrator being steeped in the maelstrom of action and humanity that Saviano the author describes. His skillful blend of non-fictional content with autofiction, materiality and irony calls attention to the uncanny mechanisms through which the Camorra creates its own deviant version of capitalism which consumes everything in its path. However, the more the reader understands about Gomorra, the easier it becomes to draw parallels between organised crime, the Italian bourgeoisie and global capitalist dynamics. In turn, Rovina borrows the literary structure of Classical tragedy to show that property speculation is a no-win scenario which poisons all those which come into contact with it and turns both actors and witnesses into victims. In addition, Vinci illustrates in Rovina the close connection between denial and downfall. 


\section{Chapter 5}

\section{Translocality}

This chapter continues my exploration of environmental narratives that grapple with the consequences of ecological abuse but expands its scope from the local to the translocal and to the universal-both in terms of place and of time. Translocal is used here in opposition to "global": whereas the term globality is associated with the homogenisation of world cultures under the influence of modern capitalism, the term translocality highlights the fact that movements of people, information and goods happen in a network of local realities that are as interconnected as they are diverse. Specifically, I will be looking at two dystopian science fiction novels: Laura Pugno's Sirene (2007) and Alessandra Montrucchio's E poi la sete (2010). Both these novels are concerned with a relatively near future where humans must live with the effects of a severely compromised global biosphere. Through the analysis of these two texts, I show how readers can explore the translocal implications of frontier ethics, nihilism and cynicism through the literary representations of radically degraded places. But before I delve into the textual analysis itself, I want to reflect again on how literary writing can encourage conversations about the major existential threats that menacingly linger at the threshold of contemporary society's awareness. 


\subsection{Transcending Political Frames}

In its New Italian Epic, Wu Ming call for a literature that helps humanity transcend its current limits (Wu Ming, New Italian Epic 60). Similarly, Timothy Morton argues in Hyperobjects that meaningful art in an era of hyperobjects cannot limit itself to encouraging intellectual understanding but has to guide humanity on a path of continuous self-transcendence:

Reasoning on and on is a symptom of how people are still not ready to go through an affective experience that would existentially and politically bind them to hyperobjects, to care for them. We need art that does not make people think ... but rather that walks them through an inner space that is hard to traverse (184).

Rational knowledge necessitates separation from the object matter but the viscosity of hyperobjects makes abstraction impossible and threatens the positivist mindset that subsumes reality to reason. This reluctance to grow past an attachment to the delusion that reason (and reason alone) can provide answers to humanity's wicked problems becomes itself problematic when reason is applied as a means to push away painful emotive experiences, to progress on a path that we know harmful. At this point, we have to ask ourselves whether denial has taken over the intellective faculties humanity prides itself in. Conversely, art that evokes hyperobjects can convey meaning beyond reason, engage with readers' dysfunctional aspects, and provide tools that enable its users to embrace the more-than-human. Moreover, a type of art that engages with more-than-human realities may be (at least for the moment) the only way to sincerely grapple with the power of hyperobjects: narrative, painting, music and sculpture are privileged channels to express and to make sense of the sublime, the divine, the mysterious. This type of art is necessarily uncanny and corrosive because it erodes the readers' comfortable hypocrisy, revealing the lameness of their self-perception. Protecting the status quo falls within the scope of propaganda. By contrast, the art of the hyperobject should introduce individuals to an irreversible emotive and intimate transformational process 
of acceptance and mourning, demolishing superstitious anthropocentrism and speciesism.

Among the arts, narrative must play a major role in constructing a mythos underlining the importance of the living world. George Marshall, founder of the Climate Outreach Information Network, notes in his book Don't Even Think About It: Why our Brains Are Wired to Ignore Climate Change that "[p]eople may hold information in the form of data and figures, but their beliefs about it are held entirely in the form of stories". Stories are not facts but, unlike facts, they enable humans to make sense of the world. Stories need not be truthful: the most important element for a story's memorability is whether it is narratively satisfying (Marshall 105-106). Marshall is not specifically talking about fiction, but about how individuals and institutions should frame a discourse about caring for the living world. However, literary narrative certainly holds a privileged position among the daily narratives through which humans explain the world to themselves and to others. Literary narratives are highly prized for their power to generate insight and to make new perspectives available to readers. By bringing to life the suffering that scientific descriptions are unable to convey, literary narrative enables readers to contemplate scenarios of extreme environmental disruption and their moral consequences.

In addition to stimulating reflection on humanity's long-term role within the biosphere, narrative offers the opportunity to involve readers who are normally unconcerned with the effects of human activity on the living world. Environmental communicators and activists striving to raise awareness of the necessity to create a sustainable economic paradigm have framed the issue in terms of environment. However, it is very easy for the general public to dismiss environmental concerns as long as they are "reported by environmental correspondents in the media in special environmental reports, covered by environmental policy that was discusses in environmental speeches at environmental conferences" (Marshall 128). This framing contributes to segregating a conversation about the kind of long term future humanity wants for itself in the closed (and rather powerless) rooms of environmental NGOs. 
The marginalisation of the discourse of humanity's impact on the planetary biosphere has been fostered by corporate advocates interested in depicting green activists as a minority but also (ironically) by green groups who have unwittingly framed a universal challenge into a partisan issue. Conversely, it is possible, through literary narrative, to provide original points of view that could grant insights about aspects of reality normally inaccessible to sensory or rational investigation and independent of political convictions.

\subsection{Uncanny Hyperobjects: Sirene}

Sirene was Laura Pugno's début novel, published in 2007. It was a finalist for the Premio Bergamo 2008, won the Premio Libro del Mare 2008 and the Premio Dedalus in 2009. Prior to Sirene, Pugno published a collection of short stories titled Sleepwalking, as well as poetry and translations.

Sirene is a deeply metaphorical novel heavily influenced by mangas, including Rumiko Takahashi's Mermaid Saga (1984-1994) and Satoshi Kon's Kaikisen (2006) (Pugno, Sirene 147). Pugno defines Sirene as a "romanzo di ricerca" [research novel] whose function is to create estrangement in the reader. This process of estrangement, Pugno adds, allows the writer to pose deep questions about our society without becoming didascalic (Biancofiore 1-2). In our conversation, Pugno explained that she wrote Sirene because she wished to approach through literature themes that our society still holds as taboo and specifically the ideas of species' borders and "untroubled" anthropocentrism. Pugno argues that our era is still dominated by anthropocentrism. However, she adds, "non riusciamo più a goderci l'antropocentrismo beatamente, e questo significa che c'è un riconoscimento della dignità e di capacità di sofferenza di ciò che non è umano" [we are now unable to enjoy a blissful anthropocentrism, and this means that we now recognise the dignity and capability to suffer of that which is not human] (Appendix B "Intervista a Laura Pugno"). Sirene's two main fictional premises are the discovery of a mysterious marine species that is as mesmerising as it is terrifying and the emergence of a deadly pandemic 
(Pugno, Sirene 3,11 ). The action mostly takes place in a submarine resort called Underwater off the waters of Nuova Baja California, sheltering the rich and powerful from the plague which is destroying humanity and from the desperate masses residing in what is left of humanity's civilisation: "i Territori" [the Territories] $(4,11)$. The complex is a corporatist technocracy ruled by the yakuza, a powerful Japanese criminal syndicate, and its population is a multiracial melting pot, although the ethnically Japanese tend to sit higher up the social ladder $(24,93)$. Sirene's science fiction dystopia happens during an unspecified, but uncomfortably proximate future where the failures of science are more glaring than its successes and the proximity of the end does nothing to soften humanity's cruelty.

\subsubsection{Imagining an Uncannily Imminent Future}

Sirene projects readers into an imminent future whose recognisable traits are the more terrifying because they assert a need to become familiar with the monstrous. This blend of dreadful and intimate recalls Freud's definition of the Unheimlich: "that species of the frightening that goes back to what was once well known and had long been familiar" and thus, the terrifying aspects that unexpectedly emerge from the Heimlich (Freud 124). 11 As explained before, the concept of "perturbante" [uncanny] is fundamental in Wu Ming's codification of NIE. According to Wu Ming, literary works which supersede the artificial barrier between fiction and non-fiction indissolubly blend reality and imagination, dreadful and familiar, shaking the foundations of the reader's world-view (Wu Ming, New Italian Epic 110-114). Based on Freud's definition, roboticist Masahiro Mori advanced the controversial "uncanny valley" hypothesis. The hypothesis holds that the human affinity towards objects does not simply follow a monotonically increasing function whereby the more an object bears human characteristics, the more it inspires agreeableness. Instead, Mori argues,

${ }^{1}$ The Oxford dictionary translates the German adjective Heimlich as "secret", but its root Heim means "home" and the suffix -lich corresponds to the English adjective-forming suffix "-like", hence its usage in this section ("Heimlich"). 
there exists a deep valley just before perfect resemblance where superficially human-like objects cause revulsion instead of attraction. However, as the similarity increases further towards perfection, the object's agreeableness rises steeply again. The feelings of attraction and revulsion are compounded where the object is perceived as moving. This is why dolls are agreeable, a corpse or a prosthetic hand are uncanny, but a zombie and a myoelectric hand are uncannier (Mori, MacDorman, and Kageki 99). Sirene's cruel representation of an immediate, apocalyptic future feels uncomfortable to the reader because Pugno skilfully portrays a society whose evils are all too familiar, demolishing utopian presumptions of the future as an upgrade of the present. In turn, Pugno's uncanny mermaids, whose anthropomorphism blends with monstrosity, force readers to question the assumption that there is a definite line to be drawn between human and non-human.

\section{The Mermaid: A Heimlich Monster}

Punctuated equilibrium is a theory of evolutionary biology advanced by Stephen J. Gould and Niles Eldredge, who claimed that evolution is "a story of homeostatic equilibria, disturbed only 'rarely' (i.e., rather often in the fullness of time) by rapid and episodic events of speciation" (84). Perhaps even more interestingly, recent research has resurrected Richard Goldschmidt's reviled theory of the "hopeful monster": evolutionary scientists have observed that small genomic modifications could cause radical mutations in in-vitro bacterial cultures. Whereas most mutations would lead to death, individuals sporting favourable modifications would rapidly out-compete their siblings and propagate (Chouard). Similarly, in a New York Times article, Olivia Judson argues that evolution in macrofauna could happen along a similar route. For instance, a single gene sequence determines the absence of feathers in the head and neck of birds, as is occasionally observed in chickens. This same mutation conferred bald proto-vultures an evolutionary advantage over their feathery siblings because it prevented them from becoming soiled when they ate from carcasses ("The Monster Is Back, and It's Hopeful"). Thus, evolution alternates 
periods of stability with times of rapid change when environmental conditions change or when successful mutants appear. But survival is not sufficient: even though hopeful monsters may possess favourable characteristics, they still walk a fine line between evolutionary fitness and death, and whereas their newly evolved characteristics may confer an edge over their siblings, they cannot afford to be so radically different as to be unable to mate. Evolution generates hopeful monsters, but only Heimlich monsters can pass on their genes to their offspring.

But biology is not the only home of hybrids, monsters and mutants: they live first and foremost in folklore and myths. Mythology provides countless examples of hybridisation - the most terrifying of which are perhaps blends of humans and animals: from werewolves to sphynxes, from centaurs to harpies and minotaurs. Among them, mermaids have been commonly represented in Western folklore as alluring women with fish-like lower bodies, instilling a mixture of sexual attraction and bestial repulsion in onlookers. Mermaids appear in folklore worldwide, with instances of myths including mermaid-like creatures dating back as early as $2000 \mathrm{BC}$ in Babylonia, where the the legendary sage Adapa was depicted as a fish-bodied man. In the manga-inspired Sirene, Pugno imagines mermaids that syncretise characteristics from Japanese myth, modern mangas and the Afrobrazilian pantheon. In Japanese mythology, the Ningyo [human fish] is an ominous creature whose flesh grants long life to those who eat it. Similarly, in Sirene, the discovery of the mermaid species closely predates the outbreak of black cancer, and their flesh is a prized luxury food for those who can afford it (Pugno, Sirene 6). At the same time, a new religion has spread among the populace, who worship mermaids as the physical incarnation of the sea-goddess Iemanjá $(35,41,42,44)$.2Pugno's mermaids blend human and animal features, providing a most striking example of uncanniness. The creatures, Pugno writes, were discovered at the bottom of the ocean when humanity started to colonise its depths. Mermaids are strange beings that can breathe in water as well as in air but at the same time are viviparous, giving

\footnotetext{
${ }^{2}$ Alternatively called Lasiren in Haiti, Iemanjá is the Afrobrazilian orixá of the ocean, the patron of fishermen and survivors of shipwrecks, and the universal feminine principle of creation, often represented as a mermaid.
} 
birth to live offspring-a biology only seen in nature in some amphibian species. Pugno describes them as resembling beautiful women, but at the same time, as radically inhuman: mermaids "erano donne, prive di parola, prive di gambe" [they were women, without speech, without legs]. Just like the manga mermaids of Rumiko Takahashi's Mermaid Saga, they possess "un'unica massa elastica verdeazzurra o azzurro vivo che scendeva sulla schiena, che ondeggiava nell'acqua come le trecce della piú splendida delle adolescenti" [a single, elastic blue-green or azure mass, which waved in the water like the braids of the most gorgeous teenager] instead of hair on their heads. Their bust is "grande e pesante con i capezzoli verdecupo, durissimi" [big and heavy with dark green, hard nipples]. But the attractiveness of the mermaids' manga-like anthropomorphic traits mixes uncomfortably with menacing animal features. Their eyes are "vuoti, spenti" [empty, dull], protected by "membrane nittitanti delle palpebre come pezzi di plastica sporca" [nictitating membranes like pieces of dirty plastic] (6). Mermaids possess razor-sharp teeth and a muscular tail "capace di spezzare in due la schiena di un uomo" [able to snap a man's back] $(57,6)$. Mermaids, Pugno writes, attract their mates through a call whose apparent animal dullness belies its power: "le sirene non cantavano per l'orecchio umano. A volte emettevano un verso stridulo di gabbiano o di foca, ma il loro canto vero era un richiamo ultrasonico che faceva impazzire i cani, e forse, per quanto impercettibile all'udito, anche gli uomini" [mermaids did not sing for the human ear. Sometimes they emitted a strident cry like a seagull or a seal, but their real song was an ultrasonic call which drove to madness dogs and perhaps—-though it was inaudible-humans] (5). In the wild, Pugno's mermaids mate with their male counterparts, who are mute animals similar to small dugongs whose sole role is to impregnate the females:

La monta era frontale ... Di solito docili come vacche, le femmine di sirena si rivelavano stupendamente feroci alla fine della monta. Non appena cessato l'estro che le manteneva narcotizzate e placide, alla mercé dei maschi, le femmine li avrebbero uccisi e in parte divorati [The mount was frontal ... Usually as meek as cows, the mermaid 
females became stupendously savage at the end of the covering. As soon as the oestrus that kept them drugged and placid, at the mercy of the males, ended, the females would kill and partially devour them] (Pugno, Sirene 4-5).

Sexual cannibalism, an adaptive strategy common to insects and arachnids where the female kills and consumes the male during or after mating, compounds the dread that mermaids inspire.

Given their charm and their deadliness, Pugno's mermaids seem to share characteristics with the sirens of Greek mythology, who lured seafarers to certain death through their irresistible songs. ${ }^{3}$ The lure of Pugno's mermaids is as ultrasound-based as it is pheromone-based, and it works as potently on humans as it works on the male of its species. As Samuel, the human main character of the novel, approaches a mermaid with the intention of copulating with her,

Samuel sentí un'erezione quasi automatica. Forse era l'odore della sirena, o cosí dicevano le voci sugli yakuza ossessionati da quelle creature. Non solo l'umore della pelle, non solo la carne e il latte di sirena, ma anche l'odore era afrodisiaco [Samuel felt an almost automatic erection. Perhaps it was the smell of the mermaid, or so said the rumours about the yakuza obsessed with those creatures. Not only the humour of the skin, not only the flesh and the milk of the mermaid, but also the smell was an aphrodisiac] (Pugno, Sirene 19).

Women, too, fall for the lure of the mermaids when exposed to their irresistible ultrasonic and chemical calls. In a bid to break the will of a cultist who worships mermaids, Samuel forces her to enter a pool where one is kept. Despite her initial resistance, "[d]avanti alla sirena prigioniera Ivy aveva perso le sue

\footnotetext{
${ }^{3}$ It is to be noted, though, that the Greek imagined sirens as women with bird features, thus more similar to harpies than to the modern conception of the mermaid. Specifically, Homer portrays sirens as mantic creatures who attract their victims through the promise of sharing their secrets, and not through sexual allure. However, in Italian, the word "sirena" indicates both the Greek bird-like sirens and the later fish-like mermaids.
} 
inibizioni, leccando e succhiando ogni centimetro di quel grande corpo. Aveva profanato la dea" [facing the captive mermaid, Ivy lost her inhibitions, licking and sucking every centimetre of that huge body. She had profaned the goddess] (Pugno, Sirene 38). Pugno engineered her mermaid species to reveal the bestial side of humans who can no more resist the fatal lure of mermaids than a moth can resist circling candlelight. After the catch, mermaid hunters "affondavano in quella carne fresca e calda con ogni parte del corpo, la bocca, i denti, la lingua, il sesso. Come drogati. Samuel ne aveva visti parecchi degradarsi a quel modo, anche grandi yakuza. Gli facevano pietà" [sunk in that cool and warm flesh every part of their body: mouth, teeth, tongue, sex. Like junkies. Samuel saw many of them degrading themselves in that way, even great yakuzas. He pitied them] (52). Sirene goes beyond exploring humanity's (horrifyingly familiar) reaction to the discovery of the beautiful mermaid species: paradoxically, the mermaids' superficially human characteristics highlight their uncanniness, whereas their animal ultrasonic and chemical calls reveal the primeval human drives that lie beneath a thin veneer of civilisation.

Pugno investigates the idea of species' border to its extremes as Sirene ventures deeper into the "uncanny valley". What could be uncannier than a mermaid? The answer is, a human-mermaid hybrid. In Sirene, Samuel unexpectedly impregnates the mermaid he copulated with, generating a hybrid with human-like eyelids, lips and vocal apparatus (Pugno, Sirene 32, 56). Eventually, Mia, as Samuel revealingly decides to call his half-mermaid daughter, learns to speak her father's name:

Mia guaí di nuovo, piú forte. La lingua tremava, batteva contro i denti, il palato si contraeva.

Samuel le prese il muso tra le mani. Qualcosa le vibrava nella gola.

Shhh-

Sssh-

$S-a-a$

$m-u$.

$S-a-m-u-u$. 


\section{Samuel}

[Mia yelped again, louder. The tongue shook, knocked against the teeth, the palate contracted. Samuel took her face between his hands. Something vibrated in her throat] (Pugno, Sirene 119).

The juxtaposition of, on the one hand, Mia's unexpected ability to speak and the description of her animality ("muso" [face] is an Italian a word exclusively associated with animals), and on the other hand, the humans' uncontrollable instinctivity further erodes the perceived barrier that lies between humanity and preconceptions of animality, encouraging a reflection about whether "human" and "animal" are really antonyms or whether humanity is a simple subset of animality, as well as questioning the validity of the "nature versus culture" dichotomy.

\section{Dread, Violence, Dominion, Impermanence}

Freud defines the uncanny as the emergence of the dreadful within the familiar. In the article The Ecophobia Hypothesis, Simon C. Estok argues that "a large part of what ecophobia is all about is an irrational fear (sometimes, of course, leading to a contempt or hatred) of the agency (real or imagined) of nature. A large part of what misogyny is all about is a fear of women's agency" (Gaard, Estok, and Oppermann 74). Mermaids are liminal creatures which sit at the intersection between the human and the non-human, between being women and animal, and between the dreadful and the Heimlich. In Sirene, their sudden appearance has profound effects on humanity because it exposes the irreconcileable contradictions within anthropocentrism. On the one hand, the Mermaid Liberation Front begins to worship them. On the other hand, their uncanny human-likeness threatens the anthropocentric foudations of the yakuza's power, which relegates them to the roles of sexual objects and source of luxury food.

Samuel, Sirene's main character, occupies an uncomfortable position in this setting of power, death and exploitation. Although he had been trained to become part of the yakuza's elite, he was discarded and, instead, assigned to 
work in mermaid slaughterhouses (Pugno, Sirene 16). Samuel lives his life at the periphery of the yakuza's power: as in other works analysed here, Sirene's readers observe facts through the "oblique gaze" of an individual who is at the same time a victim and an accomplice of oppression $(11,16)$. Samuel was living a life of quiet desperation since the death of his partner Sadako, but the unexpected birth of Mia pushes him over the edge, eventually allowing him to shatter his own anthropocentrism. This, in spite of his weaknesses, makes him willing to trade his life for his daughter's freedom, thus investing his death with significance, "un fatto non triviale durante un'apocalissi" [not a trivial fact during an apocalypse] (Appendix B] "Intervista a Laura Pugno").

Sirene is set at a time of unprecedented tragedy, and Samuel's life is saturated with grief. His job forces him to distance himself from the suffering of the mermaids: he often repeats to himself that they are not human, implying that mermaids are unworthy of a humane treatment (Pugno, Sirene 25, 31). His denial is a form of defense necessary to preserve his social status and his occupation, but Mia's birth makes it untenable. This realisation is the beginning of the end for Samuel's anthropocentrism, but he is a profoundly contradictory character who battles between awareness and denial throughout the novel and who often acts for obscure reasons.

Samuel asserts again and again the ownership of his daughter, first in his decision to call her "Mia", meaning "mine" in Italian (Pugno, Sirene 66). The second way Samuel claims ownership of Mia is through replicating Sadako's tattoos on Mia's skin. Sadako's body was completely covered in irezumi, traditional Japanese tattos which decorate the bodies of yakuza members (64). Pugno uses the same expression for Sadako and for Mia: both are "carta di riso" [rice paper], implying that their bodies are mere vehicles for the creativity of their (male) tattooers (95-96). The denial of agency is compounded by the fact that tattoos, as Sadako notes, are "una lingua incapace di mentire" [a language which cannot lie], directly relaying a message from tattooer to observer through the skin (48). Thirdly, Samuel exerts his dominance over his daughter in a third, more odious way, which even Mia's humanness and Samuel's contempt for the 
yakuzas who debase themselves with mermaids fail to prevent: rape (120). But why? The rape scene happens in the confused moments after Samuel realises that Mia is able to articulate human speech:

la scena a cui aveva assistito non significava niente. I cacatoa facevano di meglio. Ricordò gli occhi della mezzo albina, la sensazione deliziosa della monta. Somigliava a Mia, aveva un corpo identico, ma non era umana. Mi è andato il cervello in pappa, pensò Samuel, e poi non riuscí piú a pensare [the scene he witnessed did not mean anything. Cockatoos could do better. He remembered the eyes of the half-albino mermaid, the delightful sensation of the mount. She looked like Mia, she had an identical body, but she was not human. My brain has turned into mush, Samuel thought, and he could not manage to think further] (Pugno, Sirene 120).

It is true that some social animals recognise members of their own group through specific calls, but Mia had unmistakeably spoken human speech (Antunes et al.; Colombelli-Négrel et al.; Kendrick). Mia's voice brings about the undeniable realisation that mermaids are humanlike-a source of unbearable grief for Samuel, who spent his life butchering them. Denial, minimisation and deflection are textbook signs of stress, as is the subsequent violence. Mia is more human than Samuel is willing to admit, and her humanity threatens Samuel's worldview, where mermaids are food and sexual objects. In a state of stress and dread, Samuel rapes her in an attempt to dehumanise her and reestablish the comfortable status quo of anthropocentric domination that Mia's existence has upset.

And yet, delusions do not last. In Sirene, there is an oft-repeated formula: "[1]a mente è vapore che si alza da una ciotola di riso" [the mind is vapour rising from a bowl of rice] (Pugno, Sirene 65, 139, 144). Pugno presumably adapted the quote from the words of Japanese Zen master Dōgen (1200-1253) who wrote the following verses during the harvest moon of 1249 , in a poem accompanying a self-portrait: 
The mountain filled with leafless trees

Crisp and clear on this autumn night;

The full moon floating gently above the cluster of roofs,

Having nothing to depend on,

And not clinging to any place;

Free, like steam rising from a full bowl of rice,

Effortless, as a fish swimming and splashing back and forth,

Like drifting clouds or flowing water (Heine and Dōgen 129).

Dōgen's poem is a celebration of peace, freedom and impermanence: like moonlight, the "symbol of the universal manifestation of the compassion and wisdom of Buddha-nature", the liberated Mind is peaceful, free, boundless, and luminous (Heine and Dōgen 37). Just as the Moon runs unimpeded its course across the sky, attempts to clamp down on nature, tame it, and dominate it must fail. The mind is like vapour rising from a full bowl of rice: it cannot be constricted or preserved-and so, in Sirene, fate unravels regardless of humanity's attempt to control it. Mermaids, Samuel reflects, "ci succederanno sulla Terra. Non le abbiamo addomesticate, non ancora. Le teniamo prigioniere, mangiamo la loro carne. Ma non siamo riusciti ad addomesticarle" [will succeed us on Earth. We have not domesticated them yet. We keep them caged, we eat their flesh. But we have not managed to domesticate them] (Pugno, Sirene 13). Mia is half-human but she is not domesticated, in stark contrast with Sadako, whose bond with the yakuza lasts until death. Like Mia, Sadako lived a tragic life full of violence and abuse and yet her attachment to her irezumi signifies her dependency on the system that kept her enslaved $(63-65,48)$. On the other hand, whereas Mia is able to actively interact with humans through speech, she does not need them and in fact, it appears as if she embraced names (and thus culture) as no more than a survival strategy that confounds her human predators allowing her to regain her freedom. When Mia returns to the ocean, her mind becomes "tabula rasa", obliterating names, culture and grief more effectively than any technological "memory cleansing" could do for Samuel $(145,14)$. The marks of domination fade away, in one way or the other: whereas the black 
cancer destroys Sadako's irezumi and reveals the spotless "derma bianco" [white derm] before death, the vast blackness of the oceans hides the mark of humanity on Mia's skin (131-132). The story of life, Pugno seems to say in Sirene, is the only story worth telling, but it is also a story no one can control.

\section{Underwater: Language, Technology, Tyranny}

Power drives human ambition. Most of Pugno's Sirene is set in a complex called Underwater, a dystopic society governed by organised crime with ruthless efficiency, and the power of life and death over its employees. The syndicate governing Underwater is the yakuza, a umbrella term for Japanese criminal organisations which originated during the Edo period in the 17th century, notorious for their iconic rituals and whose members display intricate full-body tattoos. Although they pursue criminal activities, they are largely tolerated in Japanese society, have headquarters and are registered as corporations. However, they extensively engage in international arms, drugs and human trafficking as well as protection money, blackmail, extortion, and fraud (Kaplan and Dubro). Underwater is a society mired in tyranny and cruelty. While undoubtedly dreadful, the anxiety that its description evokes signifies its proximity with our experience. How so?

In his review of Sirene, the Italian writer and critic Tiziano Scarpa notices how Pugno pushes the limits of the Italian language, utilising loan words from English and Japanese as well as catachresis to define the new reality of Underwater. The frequent use of loan words, of foreign personal names and of invented geographical locations thwarts any effort to detect similarities between Underwater and any existing society. This narrative strategy turns Underwater into the quintessential place, the city that could be any city. Loan words are relatively common in current Italian, and Pugno uses some of them, such as "dreadlock", "sushi" and "blackout" (Sirene 4, 33, 116). However, she also introduces loan words which have no currency in Italian, even when an appropriate native word or phrase would be available. In Sirene, loan words are mostly used in the context of mermaid veterinary ("batch", "data-entry", 
"floating bed", "pet", "scubalight", "shot"), but also medicine ("facemask", "memory cleansing", "scrub") and society ("freeter", from Japanese) (43, $94,135,31,51,15,76,14,125,24)$. In so doing, Pugno highlights that, just as jargon deforms everyday language, new realities wildly intrude into our familiar everyday. In addition, the use of loan words shows how technology and language reflect each other: loan words, like innovations, are exotic (and uncanny), respectively in the ecology of society and language.

Because of their exoticism, neologisms and loan words enter a language without the baggage of cultural references and associations which indigenous words possess. In Becoming Animal, David Abram attributes modernity's destructiveness to the fact that the symbolism of writing has provided a vantage point which has enabled Homo scribens to distance him or herself from material reality, appropriate it, and manage it as if from above and beyond (Abram 281). Politicians, CEOs and generals use dehumanising euphemisms in an attempt to hide the crude reality behind their utterances: in this form of Newspeak, civilian deaths become "collateral damage"; people losing their jobs, "redundancies"; the living world, "natural capital". The Israeli military referred to the 2014 Gaza campaign as "mowing the lawn" (Vallely). This strategy works because it stops readers from forming mental images of the destruction involved, thus defusing the emotive charge of the expressions. Sirene's mongrel language reflects a reality which not only refuses to investigate the moral consequences of technology, but actively tries to sanitise them through language.

Conversely, Pugno employs catachresis to indicate an existing technology whose usage has been adapted in the current situation: the obsolete Italian word "biacca" [ceruse] defines the ointment that protects from the cancer-causing radiation of the Sun:

Spalmatevi la biacca, o il cancro nero vi divorerà.

Come uno scherzo crudele, il vero nome del prodotto era SST, Safe Self Tan. Un autoabbronzante di ultima generazione, dalla sfumatura miele o cioccolato, pronto in tubetto per la vostra pelle. I suoi insoliti effetti collaterali - protezione integrale della pelle dalle 
degenerazioni tumorali, anche se per un brevissimo periodo - erano stati scoperti solo al dilagare dell'epidemia

[Rub in the ceruse, or else the black cancer will devour you. Like a cruel joke, the real name of the product was SST, Safe Self Tan.

A latest-generation self-tan lotion, available in honey or chocolate shades, in a tube, ready to rub into your skin. Its unusual collateral effects-total protection from the tumorous degeneration, although for a very short time-were discovered only after the plague broke out] (Pugno, Sirene 75).

But, like the use of catachresis, the serendipitous discovery of the ceruse's protective properties is the exception to the rule: Underwater's advanced but imperfect technology seems to be more geared towards oppressing humans than towards protecting them.

In Sirene, technology undoubtedly assists the yakuza in dominating humanity as well as non-human species, but Pugno is not technophobic. In her interview, she argues that "la scienza non ha per me valore negativo, e allo stesso tempo, non va neanche divinizzata ... Al contempo però, bisognerebbe saper evitare gli abusi di tecnologie di cui non abbiamo completo controllo" [science does not have a negative value for me but, at the same time, it should not be worshipped ... At the same time, though, excesses of technologies we do not fully control should be avoided] (Appendix B "Intervista a Laura Pugno"). Just as Underwater's language teems with introduced words that it did not have the time to assimilate, its society relies on innovations whose moral implications have not been fully appreciated yet.

Since Charles Darwin published his Origin of Species in 1859, humans have been made aware that they share common ancestors with every other living being. However, human exceptionalism permeates and defines the current cultural paradigm to this day. The pernicious philosophy which places humans apart from nature and construes them as above the living world is a suicidal belief that encourages the destruction of the biological systems which enable humanity to thrive. In her novel, Pugno forces the reader to investigate the foggy 
borders between humanity and animality but she also suggests that culture and intelligence are no more than an adaptation to the specific conditions that humans face. Mia's uncanny, hybrid nature embodies the overcoming of the species' border, whereas her call and the oblivion of the sea are mortal blows to anthropocentrism. In Becoming Animal, Abram argues that the living world is the source of all creativity and that, through the written word, humanity risks appropriating and uprooting local knowledge from its living substrate (281-284). Indeed, there is no substitute to receiving first-hand the insights of wilderness: however, Abram adds, "[b]ooks have enabled us to partake of stories from vastly different places, ingesting insights originally rooted in other traditions and other eras" (284). Some stories, like those of mermaids, sing a non-human poetry which is almost impossible to perceive but that can demolish the foundations of human exceptionalism through empathy, enable us to experience reality from uncanny points of view, and remind those who will listen about the vastness of possibility - though they live in different places, times, or forms.

\subsubsection{Black Gods: Sirene's Hyperobjects}

In our conversation, Pugno specified that Sirene does not push an ecological agenda. However, the references to ecology in her work are clear and plentiful. In Sirene, humanity is dying because the atmospheric ozone layer has been destroyed (Pugno, Sirene 11). The causes of the depletion are never explained, but the ozone hole (like global warming) quintessentially represents the destructive capacity of industrial civilisation. As early as the 1970s, scientists theorised that halogenated hydrocarbons, artificial molecules containing bromine and chlorine, could erode the stratospheric ozone layer which protects the Earth from most of the carcinogenic ultraviolet radiation from the Sun. However, they assumed that the reduction in ozone concentration would be relatively uniform across the atmosphere and it was only in the mid-1980s that "astounded" scientists detected a continent-sized "ozone hole" above Antarctica (James Gleick qtd. in Zehr 612-613). While Silent Spring showed how industrial 
biocides disrupted local ecologies, the ozone hole demonstrated that human activity could rupture an entire planetary system and potentially jeopardize life on Earth as we know it. The choice of what is essentially an industrial accident of global proportions as a narrative engine suggests that Sirene has ethical and ecological implications.

\section{Viscosity, Interobjectivity, Nonlocality}

Specifically, reading Sirene through the framework of Morton's hyperobjects reveals how anthropocentric behaviour puts humanity on a collision course with powerful hyperobjects. In Sirene, the hyperobject-Sun bathes humans in deadly radiation after the ozone layer has ceased to protect the Earth. How does Sirene's black Sun illuminate the flaws in humanity's current relationship with the biosphere? As Morton writes, hyperobjects reveal the universal properties of viscosity, interobjectivity and nonlocality. Viscosity reveals the uncanniness of matter. As Morton discovers, hyperobjects

are all over me. They are me. I feel like Neo in The Matrix, lifting to his face in horrified wonder his hand coated in the mirrorlike substance into which the doorknob has dissolved, as his virtual body begins to disintegrate ... the mirror itself has become part of my flesh. Or rather, I have become part of the mirror's flesh, reflecting hyperobjects everywhere (28).

Sunlight provides a straightforward example of viscosity as most life on Earth depends, directly or indirectly, on photosynthesis and thus sunlight is, quite literally, a structural part of life and matter themselves. Photosynthesis allows photoautotrophs to synthesise sugar out of inorganic compounds such as water and carbon dioxide and form the foundation of the food chain. Thus, plant, animal, human and even inanimate bodies contain the Sun, they are the Sun. When, in Sirene, the life-giving Sun becomes the death-giver, the whole biosphere mutates. Plants thrive under its rays: "il sole che uccide gli uomini sembrava gonfiarle di vita meravigliosa" [the sun that killed humans seemed 
to fill them with wonderful life] (Pugno, Sirene 22-23). Whereas life is resilient and adaptable, Sirene intimates that humanity is fragile. The radiation of the black Sun permeates human bodies, causing a deadly disease called "cancro nero" [black cancer], a form of melanoma which causes the skin to be covered with black spots and then fall off before killing the victim (23). As the plague spreads, the conditions which favoured humanity's ascent cease to exist and, like the skins of the black cancer victims, cities develop ever-expanding dead black spots, where society crumbles:

La mappa della città era piena di deserto, una pelle di leopardo coperta di chiazze nere. Le aree sequestrate. Gli ospedali. I campi di detenzione temporanea, che durava fino al momento della morte.

A Underwater, il cibo cominciava a scarseggiare per tutti, ma non per gli yakuza.

Tutto stava ritornando selvaggio

[The map of the city was filled with desert, a leopard skin covered with black spots. The confiscated areas. The hospitals. The camps for temporary detention, which lasted until the moment of death. In Underwater, food was running out for everyone, but not for the yakuza. Everything was returning to wilderness] (Pugno, Sirene 13).

Although one hundred and fifty million kilometres physically separate the Sun from the Earth, sunlight is interwoven into every single living cell. Pugno imagines a world where the Sun has become a black god of death whose rays poison humanity instead of nurturing it. The viscosity of Pugno's Sun reminds the reader of the delicate balance which sustains humanity, and of the interdependence of life.

In addition to viscosity, hyperobjects reveal interobjectivity, the emergent properties of the interaction between two or more objects. The electric wiring of a house, Morton explains, is an example of an interobjective system:

lightbulbs, a microwave oven, wire, fuses, three computers, solar panels, and plugs are distributed so that energy flows among 
them as evenly and as equally as possible. If they were arranged differently-if the circuitry were put in series rather than in parallel—then they would perform very differently: some items would not operate at all, and some would be at a much higher risk of bursting (Morton 82 ).

Likewise, human life is the result of a particular arrangement within an interobjective system, existing as an emergent property of innumerable conditions, of which we understand but a small fraction: once again, Sirene demonstrates humanity's fragility by imagining a scenario where one of these conditions ceases to exist.

An interobjective system exists between Sun, Earth, photons, atmospheric ozone layer, and genetic material: one of the relations which make life on Earth possible. The Sun emits a wide spectrum of radiation, some of which is energetic enough to penetrate cell walls and damage DNA. Fortunately, stratospheric ozone absorbs the most destructive radiation. Without this thin protective layer, "the Sun's intense UV radiation would sterilize the Earth's surface" (Newman). The thickness of the stratospheric ozone layer is measured in Dobsons, a measure of roughly equivalent to 0.01 millimetres at sea-level pressure and at $0^{\circ} \mathrm{C}$ (Schwartz and Warneck 1391). Normal ozone concentrations average about 300 Dobsons-roughly 3 millimetres-whereas the so-called ozone hole over Antarctica measures below 220 Dobsons.

In Sirene, the stratospheric ozone layer ceases to offer protection from the Sun's radiation: "qualcosa era cambiato nell'atmosfera, negli strati di protezione che separavano la Terra dalla stella del suo sistema, e ora il sole sembrava voler divorare l'umanità come un dio maligno. Un dio azteco che chiedeva sacrifici" [something had changed in the atmosphere, in the protective layers that separated the Earth from the star of its system, and now it seemed as if the Sun wanted to devour humanity like a malignant god. An Aztec god demanding sacrifices] (Pugno, Sirene 11, 10). Like an inept electrician tampering with a barely understood electric system, Sirene's humanity has caused its own demise. However, for Pugno, exposing fragility of humanity is also a way to 
celebrate the resilience and adaptability of life. As the black sun radiates death on humanity, life fills the ecological niches that humankind cannot hold any more: Samuel reflects, "[l]e sirene smetteranno di vivere in fondo al mare e ci succederanno sulla Terra" [mermaids will cease to live at the bottom of the sea and will succeed us on Earth] (13). For all its technological prowess, Underwater cannot avoid its grim fate because human society can never be abstracted from the biosphere. Wherever the fragile balance which sustains it fails, humanity disappears.

After viscosity and interobjectivity, the third property that hyperobjects expose is nonlocality. Morton explains that "[n]uclear radiation is not visible to humans. The nuclear accidents at Chernobyl and Fukushima bathed beings thousands of miles away in unseen alpha, beta, and gamma particles, as radioactive specks floated in air currents across Europe and the Pacific. Days, weeks, months, or years later, some humans die of radiation sickness. Strange mutagenic flowers grow" (38). Humans experience reality through the limited window which their senses allow them to perceive, whereas "[h]yperobjects seem to inhabit a Humean causal system in which association, correlation, and probability are the only things we have to go on, for now" (398). Likewise, in Sirene, the unspoken cause of the destruction of the ozone layer exposes the Earth to invisible - and yet deadly-ultraviolet radiation. Just as Morton's hyperobjects are withdrawn from sensoriality, the cause of the ozone depletion in Sirene is unknowable, and ozone and ultraviolet radiation are invisible to the naked eye. Despite their undetectability, hyperobjects never fail to express themselves-albeit skewedly. Morton suggests that, "[i]n some sense, cancer is the physical body's expression of radioactive materials" (54). Likewise, black cancer is, in Pugno's novel, the physical body's expression of the industrial violence that humans perpetrate on the biosphere. The anthropocentric disease that afflicts the mind of the yakuza manifests itself in the form of disease which threatens to kill the body of humanity.

Is humanity thus incurably sick? As David Abram notes in the afterword of Material Ecocriticism, the Western cultural failure to perceive the air as a living 
and life-giving medium turns it into "the perfect dump site for the unwanted by-products of our industries, for the noxious brew of chemicals exhaled from the stacks of our factories and power plants" (Iovino and Oppermann 302). But even though the gases may be out of sight and out of mind, the nonlocality of hyperobjects guarantees their agency. Similarly, the failure of Sirene's humanity to become aware of the depletion of the ozone layer and of the mermaids' suffering brings about death and destruction. Towards the end of Sirene, Samuel reflects that perhaps it was true that "il cancro nero era il giorno del giudizio sulla Terra. L'epidemia sarebbe cessata solo quando l'umanità avesse restituito le sirene all'oceano, venerandole, mettendosi al loro servizio" [the black cancer was the Judgement Day on Earth. The epidemic would stop only when humanity returned the mermaids to the ocean, worshipping them and serving them] (Pugno, Sirene 132). Perhaps the black cancer is Judgement Day for Underwater, but there is no sense of justice in the destruction of humanity, only the enormous suffering of those waiting for death under the murderous Sun, and the personal tragedy of Sadako's black cancer. Just or not, it is important to recognise that Underwater's fictional ruin tells readers something about humanity's real opportunities. As Morton argues,

[g]uardianship, care- to curate is to care for. We are the curators of a gigantic museum of non-art in which we have found ourselves, a spontaneous museum of hyperobjects ... The attempt to care for hyperobjects and for their distant future guardians will strikingly change how humans think about themselves and their relationships with nonhumans (121).

Sirene's mermaids embody the biosphere, whereas the black cancer is the consequence of humanity's destructive anthropocentrism. With her novel, Pugno brings to our attention the subtle connections between anthropocentrism, ecological destruction and human suffering by depicting a world devastated by black cancer and industrialism-thus hinting at the possibility that a different attitude to life could be the way forward. Worship and guardianship are different ways that lead to an increased appreciation of the fragile conditions 
that make life possible, illustrating a new humanistic teleology which does away with materialism and may allow humanity to prosper during the Anthropocene and beyond.

\section{Hypocrisy, Weakness, Lameness}

In Hyperobjects, Morton argues that the interaction between hyperobjects and humanity reveals hypocrisy, weakness and lameness. What does Pugno's black Sun tell us about these qualities in the era of hyperobjects? Hyperobjects doom humanity's supremacism, cannot be ignored and pose wicked problems which possess no rational solution. Sirene describes a humanity which, despite its technical advancements, is powerless to save itself. There is no cure for the black cancer and the only fragile safeguard against the Sun's carcinogenic radiation is the serendipitous discovery of the protective properties of a self-tanning lotion (Pugno, Sirene 75). Underwater's science is obsessed with black cancer, but is as powerless as the zealots of the Mermaid Liberation Front who claim that the black cancer will stop through wearing mermaid costumes and offering oranges to the sea goddess. However, Sirene suggests that, had humanity worshipped - cared for-the biosphere, the ozone layer would still protect the Earth, and the tragedy of the black cancer would not have happened. Pugno's tortured mermaids are a visible metaphor for humanity's invisible crimes, perpetrated in the name of nihilism: Underwater is doomed because power and rationality can find no reason to preserve it. Hypocrisy is utilitarianism rationalising its powerlessness to protect humankind. A hypocrite performs a cost-benefit analysis instead of running to save a child about to be run over by a truck: too late, the child dies (Morton 134-135). Likewise, twenty years of international high-level cost-benefit analyses and conferences on global warming have delivered exactly nothing: anthropogenic carbon emissions keep rising following a beautifully geometrical curve. There is a lesson here for the reader: if we allow rationality and self-interest to dictate our relationship with the cosmos, we are denying a great part of ourselves, and a fundamental survival tool. In Sirene, Samuel is a deeply flawed hero who often acts irrationally, following 
instinct rather than reason: he may be foolhardy and violent, but a hypocrite he is not. He does not know why he risks his life to mount the captive half-albino mermaid who conceives Mia, why he smuggles Mia away from the yakuza's breeding vats, or why he covers Mia's skin with tattoos. No premeditation compels him to rape Mia but, at the same time, no self-interested calculation convinces him to sacrifice his life to secure Mia's freedom: the single act which redeems him-and perhaps humanity.

Weakness is the second characteristic that arises when confronting hyperobjects. As Morton argues, the futurality of hyperobjects forces humanity to interact with beings so withdrawn that they can hardly be imagined. However, imagination enables empathy and foresight, which in turn make it possible to bear pain today in order to prevent a greater loss tomorrow. In the 1970s, the ozone hole hyperobject manifested itself and revealed humanity's weakness, forcing it to choose between profit for halogenated hydrocarbon producers and the preservation of the protective ozone layer. Ratified in 1987 despite resistance from industry, the Montreal Protocol on Substances that Deplete the Ozone Layer was an example of successful international cooperation that determined the phasing out of the production of ozone-depleting substances such as chlorofluorocarbons. NASA's "expected future" projection indicates that, thanks to the Montreal Protocol, the Antarctic ozone hole will be almost closed by 2060. However, a very different future would be expected in the absence of regulation: NASA's nightmarish "avoided future" projection. In this scenario, peak summer UV irradiation in the Southern hemisphere would almost triple by 2060: from current 9 (very high) to 25, which would be intense enough to cause sunburn in five minutes, with deleterious effects on animals, plants and on skin cancer rates (see figure 5.1.) (Douglass, Newman, and Solomon 46; Carlowicz and Lindsey). NASA's supercomputers use algorithms which describe physical laws to produce a symbolic representation of the likely outcomes of human choices. The wriggly lines and the globe smudged green, purple and orange tell us a story, and the reason why we find them terrifying is that we cannot avoid imagining life under the conditions described. From this point of view, scientific 

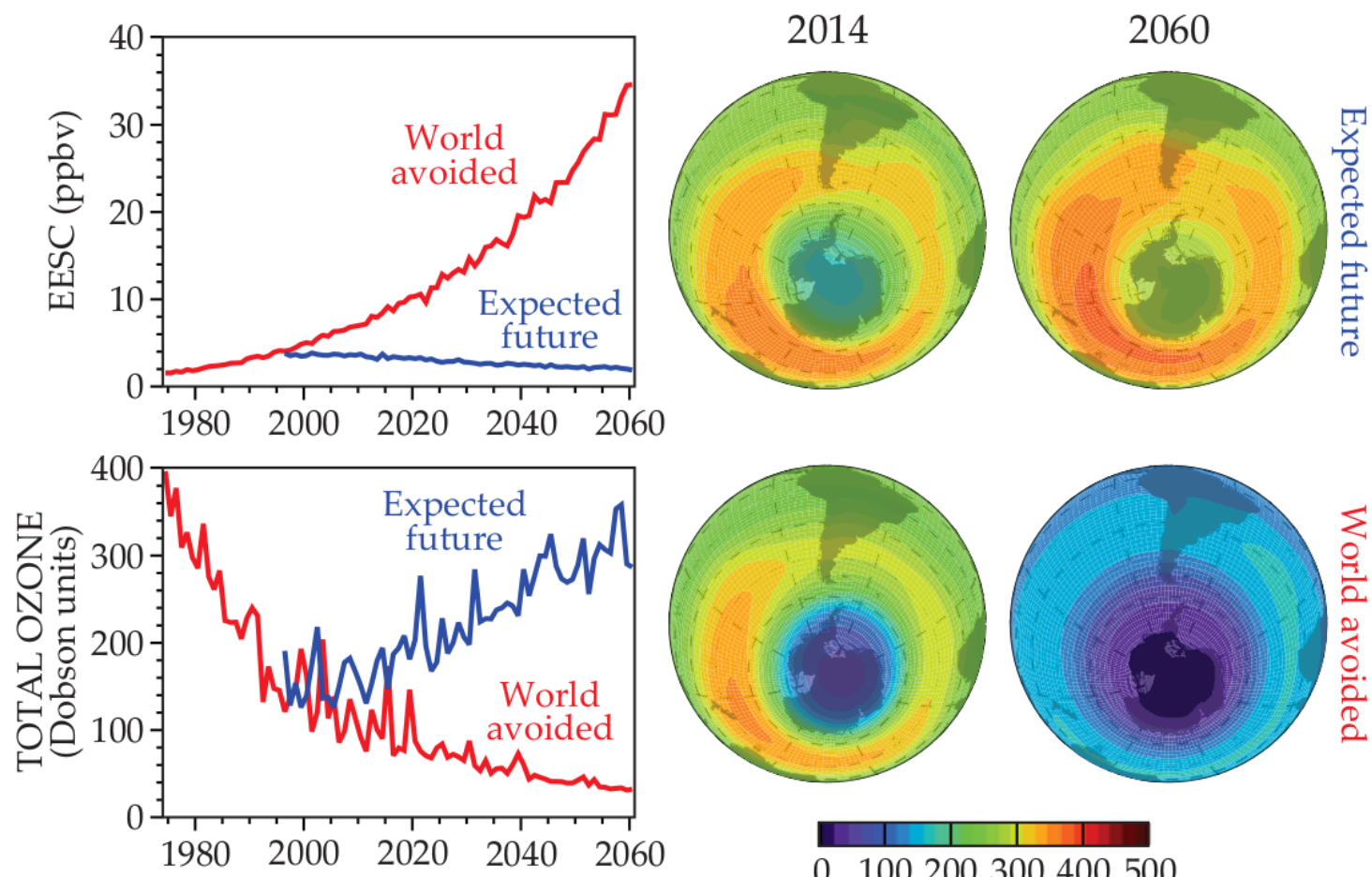

Figure 5.1: "Simulations of the Antarctic ozone hole contrast the 'expected future' (blue lines at left and top images at right) resulting from curtailing chlorofluorocarbons and a 'world avoided' scenario (red lines and bottom images) in which CFC use increases annually by $3 \%$. In the top left, the equivalent effective stratospheric chlorine (EESC) accounts for the influence of chlorine and the moredestructive bromine, both products of anthropogenic gases. The plotted EESC, in parts per billion by volume, is the average over $75^{\circ}-90^{\circ} \mathrm{S}$ at $20 \mathrm{~km}$. The bottom left plots the October ozone column density averaged over the same region. By 2014 the EESC in the 'world avoided' is almost twice that in the 'expected future,' and total ozone is about 80 Dobson units less. By 2060 the EESC is 17 times as high, Antarctic total ozone is 260 DU less, and large ozone depletions cover the entire globe" (Reproduced with permission from Douglass, Newman, and Solomon 47. Copyright 2014, American Institute of Physics.). 
discourse is similar to narrative because both narrative and scientific modelling begin with a "what if" question. However, whereas computer models attempt to describe a physical reality, narrative attempts to portray a human reality. It is true that mermaids will not surface from the depths of the ocean any time soon, but it is necessary to remember that Pugno's mermaids are metaphors: similarly, NASA's ozone models do not predict that the skies will turn green and orange. Although narrative may lack the precision of science, its immediacy allows readers to extrapolate current trends into the future and provides a vantage point which reveals the hyperobjects' futural gap. Witnessing the chain of causes and effects allows humans to overcome the hyperobject-induced weakness and makes it possible for humanity to care for the unseen and the unimaginable.

The era of hyperobjects is an era of lameness as well as of hypocrisy and weakness. Lameness (in Morton's sense of the word) is a particularly conspicuous theme in Sirene: as the mermaids encounter humanity, hybrid Mia is born, subverting the very concept of humanness and of species border, and questioning the validity of anthropocentric claims. However, hybridisation is not limited to the sexual sphere. In Sirene, the viscous, mutagenic solar radiation which bathes Earth penetrates human cells and metamorphoses them into deadly cancerous growths, turning healthy men and women into agonising bodies and civilisation into a shadow of its former self: "l'essere umano era destinato a sparire. Altre creature, suboceaniche, avrebbero dominato la Terra" [the human being was destined to disappear. Other suboceanic creatures would dominate the Earth] (Pugno, Sirene 10). Samuel's perfect happiness with Sadako vanishes as she becomes sick and dies. Underwater, the city "che doveva espandersi fino a coprire la Terra" [that was supposed to expand to cover the Earth] is in agony, its hubristic ambition thwarted and frustrated (22). Lameness is an intrinsic property of reality but humanity finds it easier to imagine eternity rather than painfully observing that everything is bound to change beyond recognition, making humanity prone to becoming entangled in delusion. In Sirene, Pugno depicts a humanity that has mutated so profoundly under the emanations of the hyperobjects that it cannot recognise itself. Therefore, it 
dissociates: on the one hand the yakuza, stuck in an anthropocentric past and grasping at power through denial, and on the other the Mermaid Liberation Front, idealistically embracing a posthuman future. Pugno's novel reminds readers that humanity exists in a primordial soup of objects and cause-and-effect relationships from which it cannot abstract itself.

Sirene provides an uncanny portrait of a humanity grappling with powerful hyperobjects, and whose nihilistic anthropocentrism spells its doom. The backdrop of a humanity which desperately grasps at the source of its own destruction contrasts with Samuel's realisation about the limits of human agency - or rather, contrasts with the fact that human agency must interact with a multitude of other agencies. The era of hyperobjects challenges humanity to review its anthropocentric stance and its exceptionalism, forcing it to realise that only an ignorant version of humanism concerns itself with humans exclusively, abstracting them from the wider context in which they are immersed. In fact, humans are required to become the caretakers of the cosmos because their flourishing depends on a wondrous transdimensional and interobjective system that rationality can hardly begin to grasp. Otherwise, humanity may find itself permeated in hyperobjects far less benevolent than the beautiful (though uncanny) mermaids.

\subsection{A Climate of Fear: E poi la sete}

Alessandra Montrucchio is a Torinese author and a translator. She writes a fortnightly column for La Stampa-: "Cattive ragazze" [Bad Girls]. In addition, she authored titles such as Cardiofitness (1999), Macchie rosse (2001), Fuoco, vento, alcol (2006) and E poi la sete (2010). E poi la sete is notable for being one of first novels written by an Italian author (and one of the few written so far in Italian) where global warming takes a central role in the narrative. Other examples of Italian narrative where global warming influences the plot include Tommaso Pincio's Cinacittà (2008), set in a future Rome beleaguered by high temperatures, and Antonio Scurati's La seconda mezzanotte (2011), set in a Venice rebuilt by the 
Chinese after a flood destroyed it. However, in E poi la sete, the effects of global warming are portrayed as more extreme and more central to the narration than in Pincio's and Scurati's novels. Because of this reason, because of the limits imposed by the format of the thesis, and because of Montrucchio's overtly political authorial intention, I have chosen to prioritise the analysis of E poi la sete, leaving Pincio's and Scurati's novels for future analysis.

\subsubsection{Literary Writing: The How and the Why}

Science indicates that global warming likely is and will be the cause of a host of potentially apocalyptic events: extreme weather, droughts, floods, sea level rise, loss of ice sheets and an accelerated rate of extinction. Unchecked global warming is going to reshape major physical and human features of the Earth: sea level rise alone threatens the displacement of up to 187 million people in the 21th century, the Artic is likely to be ice-free in summer within the next two or three decades, and over the longer period, the enormous Antarctic Thwaites glacier is set to collapse (Nicholls et al. 172; National Snow and Ice Data Center; Joughin, Smith, and Medley). But notwithstanding the scientific warnings of dramatic changes that global warming brings about, and the need for narratives that address the issue, as late as 2005, Robert Macfarlane was lamenting that global warming

still exists principally as what Ballard has called "invisible literature": that is, the data buried in "company reports, specialist journals, technical manuals, newsletters, market research reports, internal memoranda". It exists as paper trail, as data stream. It also exists, of course, as journalism, as conversation, and as behaviour. But it does not yet, with a few exceptions, exist as art ("The burning question").

As Barbara Kingsolver points out, the relative scarcity of titles related to global warming could be caused by the fact that "translating scientific ideas from physics and mathematics and biology into vernacular English is difficult enough, and then translating it into fiction so that it's all there unobtrusively is extremely 
challenging" (Lichtman and Kingsolver). However, this "translation" is not and should not be literal, as scientific and literary discourse endeavour to answer fundamentally different questions about the universe. Thus, notwithstanding the difficulties, authors have begun to spotlight the "invisible literature" of global warming, and grasp the narrative possibilities that its reality offers, creating alternative realities that reveal truths about readers and the world they inhabit.

Montrucchio explains her decision to write her novel in a brief "Postilla" [Apostille] which follows the conclusion of the novel. There, she writes that " $E$ poi la sete è un romanzo, e come tale racconta una storia non-vera, non-accaduta. Ma i problemi su cui si basa sono veri eccome. Accadono ogni giorno, ed è per questo che ho voluto affrontarli" [E poi la sete is a novel and, as such, it tells a story which is not true and which has not happened. But the problems upon which it is based are very real. They happen every day, and this is why I have decided to address them]. She continues: "1.200.000.000 di persone non dispongono del minimo vitale d'acqua quotidiano ... e circa altrettante muoiono ogni anno di disidratazione o malattie trasmesse da acqua infetta" [1.2 billion people cannot access the daily minimum quantity of water ... and about the same number die every year from dehydration or sickness transmitted through infected water] (Montrucchio, E poi la sete ch. Postilla). Montrucchio here makes two factual claims outside of the narrative, and factual claims, unlike narrative claims, invite empirical verification. It is hard to trace the source of Montrucchio's assertions but the 2014 report "Progress on drinking water and sanitation", the World Health Organisation (WHO) states that "[m]ore than 700 million people still lack ready access to improved sources of drinking water ... More than one third of the global population - some 2.5 billion people - do not use an improved sanitation" (6). In the report "Safer water, better health", the WHO estimates that more than 3.5 million people (of which more than 3 million are children between 0 and 14 years of age) die every year of diseases related to water, sanitation and hygiene (Prüss-Üstün et al. 12). Thus, there is no denying that lack of access to clean water sources is a serious problem for millions of people in less developed countries. However, official figures do not 
seem compatible with the claim of the author that more than one billion people die each year of waterborne diseases. Yet, the factual accuracy of E poi la sete's Postilla is of secondary importance in the greater economy of a novel, simply because it defines the author's ethical motivation rather than being an attempt to mislead readers. From this perspective, numbers make little difference: our ideals are hardly ever the result of calculation, but of our world-view. On the one hand, for a humanist, the loss of even a single life represents an incalculable loss. On the other hand, as the outstanding success of the reactionary campaign to discredit climate science shows, no amount of facts and data can convince the ideologues of free market fundamentalism, ready to place humanity at existential risk in their blind pursuit for profit. Barbara Kingsolver reminds us of the authorial challenge to translate scientific ideas into the vernacular and into collective consciousness. In his Treatise on Human Nature (1739), David Hume states that "the distinction of vice and virtue is not founded merely on the relations of objects, nor is perceived by reason" (246). If we accept that the goal of the sciences is to use reason to understand the natural world, then it is impossible to ascribe to it intrinsic ethical goals: scientific knowledge is, in itself, ethically neutral, therefore indifferent to the plight of humanity or even life. Conversely, I believe that literature ought to be a space where philosophical and ethical issues come at the forefront, aiming to explore not simply how the universe works but why should we care.

\subsubsection{Envisioning Hyperobjects: Climate Fiction}

Climate fiction (or, cli-fi) is sometimes considered a subgenre of science fiction, but differences are notable. Classic science fiction à la Star Wars or Star Trek often portrays a humankind which has found a way to escape the Earth's gravitational field and is intent on replicating its petty imperialistic tendencies on a galactic scale. The attitude which would have us believe that "the truth is out there", that humanity's manifest destiny is space-faring has interesting similarities with the phenomenon that Morton defines as "meta syndrome": 
"Anything you can do, I can do meta." Isn't this the maxim of modernity? For two hundred years, performing intelligence has been about saying something like "I am smarter than you to the extent that I can see around mere objects, or through your 'naïve' attitude." Being right in philosophy has most often been a case of going meta (146).

Modernity is all about going meta: evading the gravitational field of objects in a quest for the mastery of ever-bigger, more complex realities. Except that it is impossible. Astronauts are the first to recognise that briefly abandoning the Earth caused them to feel even more poignantly aware of their being earthbound. Similarly, meta-analysis is unable to bridge the rift that separates perception from existence. Viscosity prevents humanity from escaping the hyperobjects' field of attraction: modernist fantasies of escapism to space or in the realm of metaphysics are unable to provide answers in the coming Era of Hyperobjects.

Climate fiction is a literary genre that "describes a dystopian present, as opposed to a dystopian future, and it isn't non-fiction or even science fiction: clifi is about literary fiction" ( $(\mathrm{Haq})$. Therefore, cli-fi adopts a different approach to science fiction. Like storm chasers closely following tornadoes, cli-fi consigns the reader to the eye of the hyperobject instead of attempting to provide an external point of view. This certainly applies to E poi la sete. While Montrucchio's novel is set in a dystopian future, she tells an all-too-familiar story of thirst (for power and for water) in a way that makes it clear she is referring to current events: global warming and access to water. E poi la sete narrates of two people's attempt to survive the chaos and anarchy that ensue from a coup d'état in a society where people live in different sectors according to class, and where access to drinking water is a privilege rather than a right: "Alphadel apparteneva ai ricchi, a chi comprava e sceglieva l'acqua; erano i poveri a non scegliere, a bere l'acqua pubblica o riceverne una bottiglia all'ospizio di carità - erano loro a morire." [Alphadel belonged to the rich, to those who bought and chose water. It was the poor who did not choose, who drank public water or received a bottle from the charity hospice-it was they who died] (Montrucchio, E poi la sete ch. Ieri. Tarda mattinata). Montrucchio heavily relies on the senses to convey the chaos and 
the violence that beset her dystopia. On the one hand, threatening noises whose source cannot be clearly located create an ambience of fear and uncertainty:

[s]coppi di urla, gemiti, anche il pianto di un neonato. Trapestii, stridi come se venissero spostati dei mobili pesanti. Ansimi, qualcuno che si picchiava o soffocava o faceva sesso, magari. Porte che sbattevano, passi irregolari nei cortili a fianco, in strada. Un richiamo, poi silenzio. In lontananza un vocio, così costantemente in sottofondo da essere diventato impercettibile. Una specie di tuono, di quando in quando. Crepitii di fiamme, detonazioni, altre urla e una volta, una soltanto, il ronzio di un grosso veicolo [bursts of screaming, groans, even the cry of an infant. Rummagings, screeches as if heavy furniture was being moved. Gasps, someone was struggling or suffocating or maybe having sex. Slamming doors, irregular steps in the nearby yards, on the street. A call, then silence. In the distance, a murmur so constantly in the background that it became imperceptible. A kind of thunderclap, now and again. The crackling of fires, detonations, more screaming and once, once only, the whirr of a large vehicle] (Montrucchio, E poi la sete ch. Domani. Sera)

On the other hand, the word "puzza" [stench] is repeated almost obsessively thoughout the novel. Foul odors create an oppressive atmosphere in E poi la sete: "c'era un tanfo difficile da sopportare. Umanità che non si lavava da settimane, vestiti luridi. I bambini puzzavano di vomito e merda, gli adulti di ascelle e alito guasto, molte donne di marcio: mestruazioni" [there was a stench that was hard to bear. Humans who had not cleaned themselves for weeks, filthy clothes. Children stank of vomit and shit, adults of armpits and foul breath, many women of rot: menstruation] (Montrucchio, E poi la sete ch. Domani. Mattina). Cli-fi's dirt, death, blood and shit contrast the idealised future envisioned in classic science fiction where handsome and heroic humans (and improbably anthropomorphic aliens) inhabit shining artificial structures located in space. Modernism inherited its mind over matter ethos from the Christian and Cartesian dualistic contempt for the so-called res extensa. However, abstraction 
from hyperobjects is an impossible proposition as humanity is completely and irretrievably immersed in them, permeated by them, hybridised with them. Thus, instead of futilely attempting to escape hyperobjects, cli-fi explores them thoroughly.

Montrucchio's novel describes the grim suffering of people betrayed by their predecessors and whereas the scenario she describes feels at time unrealistic, she is not the only one to imagine a bleak future unless greenhouse emissions are substantially and presently curbed. In his The Weather Makers (2010), Tim Flannery hopes that a "significant decarbonising" of grids and transportation will happen no later than 2050. Otherwise, he argues, the consequent climactic shift will likely be too great for civilisation to bear. Flannery envisions two scenarios: in the first, "humans are thrust into a protracted Dark Ages far more mordant than any that has gone before, for the most destructive weapons ever devised will still exist, while the means to regulate their use, and to make peace, will have been swept away". In the second, humans would have established "an Orwellian-style world government with its own currency, army and control over every person and every inch of our planet" in order to survive (Flannery 291). E poi la sete is set in what Flannery defines as a "Dark Ages" scenario, where no strong leadership can establish a (no matter how tyrannical) world order. Montrucchio foresees a future of strife: il "mondo era in guerra" [the world was at war] (Montrucchio, E poi la sete ch. Domani. Notte). China and Siberia fight to control the Ganges' water and a reference is made to a past "guerra dell'acqua" [water war] (ch. Ieri. Tarda mattinata, ch. Ieri. Dopo pranzo). The second difference is one of internal stability: Flannery's "Earth Commission for Thermostatic Control" would need to last for centuries in order to let the Earth's systems regain their balance, but Montrucchio's dictatorship is corrupted, and soon overturned (Flannery 291, 292). Both Montrucchio and Flannery predict that a switch to renewable and nuclear energy will eventually be inevitable. Indeed, the city of E poi la sete seems to have abandoned (it is unclear whether through compulsion or will) the production of energy through the combustion of fossil fuels, and instead relies on wind farms, solar power and imported 
nuclear energy (Montrucchio, E poi la sete ch. Tra un anno). Both Flannery and Montrucchio help us, in different ways, to visualise possible outcomes for the collective course of action we are taking now.

\section{The Tempo of Hyperobjects: Phasedness and Temporal Undulation}

Climate fiction highlights how humans interact with the hyperobject global warming. I have already explored how Pugno's Sirene exposes the viscosity, the interobjectivity, and the translocality of hyperobjects, and how her depiction of the hyperobjects that lies at the boundary of human experience reveals the weakness, hypocrisy, and lameness of the human condition. However, two more characteristics define hyperobjects: phasedness and temporal undulation.

Hyperobjects are phased: "they occupy a high-dimensional phase space that makes them impossible to see as a whole on a regular three-dimensional humanscale basis" (Morton 70). Humanity's constrained field of vision perceives them like the inhabitants of Flatland would perceive a solid figure moving through their universe: a dot suddenly appears out of nowhere, a shape emerges and enlarges, mutates unpredictably, and finally vanishes, only partially and unsatisfactorily fathomable in hindsight through abstraction and metaphor. This quality of hyperobjects directly links the contemporary context with the fictional time of E poi la sete, because today's humanity traumatically experiences the inklings of global warming, whereas Montrucchio attempts to outline its full form. Although fictional, the events she presents can help readers to understand the risks currently facing humanity because of its profligate abuse of the Earth's natural resources. Montrucchio's dystopia bases its narrative on the same elements that Tim Flannery calls "tipping points ... for Earth's climate: a slowing or collapse of the Gulf Stream; the demise of the Amazon rainforests; and the release of gas hydrates from the sea floor" (Flannery 190). Montrucchio inserts within the narration snippets of a fictional history book, which she uses to narrate how global warming led to the collapse of civilisation in 2088, identifying exactly the same triggers as Flannery: “l'interruzione della Corrente del Golfo ... il tracollo delle foreste pluviali ... il rilascio di metano dal fondale 
marino" [the interruption of the Gulf Stream ... the demise of the rainforests ... the release of methane from the sea floor]. However, she imagines that the three triggers Flannery identifies trip almost synchronously in 2088 (Montrucchio, E poi la sete ch. Domani. Ancora pomeriggio). In the "Postilla" Montrucchio expresses her worry at the prospect that the world may warm "dai 14 gradi centigradi di oggi ai 20 del 2100" [from the current 14 degrees centigrade to the 20 of 2100]: an extreme scenario which Mark Lynas describes in his non-fiction book Six Degrees (2007) (ch. Postilla). Montrucchio's novel is a dystopic ucronia which endeavours to imagine human life in an arid, cruel future Earth whose apocalyptic harshness is the direct result of the current political unwillingness to consider the consequences of unchecked growth.

In addition to phasedness, Morton argues, hyperobjects exhibit temporal undulation: they "envelop us, yet they are so massively distributed in time that they seem to taper off, like a long street stretched into the distance" (Morton 55). It is interesting to note that "tempo" means both "time" and "weather" in Italian: E poi la sete reveals the mutations that global warming forces upon the twin meanings of this word. The timescales of global warming are so terrifyingly vast as to feel like eternity from a human point of view, a concept well-exposed in Chris Stenner's, Arvid Uibel's and Heidi Wittlinger's short film Das Rad (2003), which depicts human civilisation rising and falling like a tsunami from the geological point of view of two animated rocks. "Carbon is forever", is the title of a Nature report in which Ken Caldeira explains that " $50 \%$ of a $\mathrm{CO}_{2}$ increase will be removed from the atmosphere within 30 years, and a further $30 \%$ will be removed within a few centuries. The remaining $20 \%$ may stay in the atmosphere for many thousands of years". In addition, long-term climate modelling shows that, "whether we emit a lot or a little bit of $\mathrm{CO}_{2}$, temperatures will quickly rise and plateau, dropping by only about $1^{\circ} \mathrm{C}$ over 12,000 years" (Inman). The carbon that our cars, aeroplanes and power stations release now will heat the atmosphere tens of thousands of years from now, an unimaginably vast expanse of time. In fact, humans can easily theorise infinity, but find it problematic to visualise the "very large finitude" that hyperobjects occupy (Morton 60). Whereas 
the monotonic emptiness of eternity can be easily visualised, the dense finitude of hyperobjects can be only imagined with the help of narrative, which can phase readers to an uncannily vast future whose humanity feels familiar but whose inhumanity feels estranging and terrifying. Narrative prevents us from dismissing the future as an infinite void and replaces emptiness with a vast finitude populated with stories: storytelling turns time into something present, real, threatening.

In E poi la sete, although there are several references to the year 2088, the year when the climatic catastrophe called "la Caduta" [the Fall] took place, there is no indication as to the time when the action takes place: it could be decades or centuries after it (Montrucchio, E poi la sete ch. Domani. Ancora pomeriggio; ch. Dopodomani. Sera). Indeed, time in E poi la sete has a circular and self-referential property: its characters are lost in the never-ending present of the very large finitude of the post-Fall era, defined by the temporal undulations of the global warming hyperobject. E poi la sete is a tragic tale where everything changes so that everything can stay the same: the bloody revolution that many hoped might reinstate democracy is revealed to have been an orchestrated power grab. The novel opens with one corporation controlling the city's water supply and ends with its competitor doing the same:

Ecco chi c'è dietro la rivolta in nome della Democrazia popolare diretta. Non 1'Mra [Movimento rivoluzionario autonomo], non io. E non c'è né ci sarà mai una Democrazia popolare diretta ... La caduta, come nel 2088. Allora era crollato un mondo, adesso non crollava niente, ed era questo il male

[Here is who is behind the revolution in the name of Popular Direct Democracy. Not the AMR [Autonomous Revolutionary Movement], not me. And there is no Popular Direct Democracy, nor will there ever be ... The Fall, like in 2088. Back then, a world collapsed, now nothing did, and this is the trouble] (Montrucchio, E poi la sete ch. Fra tre giorni. Mezzogiorno). 
As opposed to the linear understanding of time of Judaism and Christianity, where time begins and ends with a divine act, endless return is a conception of time which was prevalent in the West until the advent of Christianity and is, even now, widespread in Eastern philosophies in the concepts of rebirth and karma. Millenarism is only possible when time is perceived as linear but, like denial and techno-faith, platitudes about the "end of the world" and "saving the planet" are flawed discourses, a failure of the imagination, a lazy cop-out:

narratives of doom about the "end of the world" are ... part of the problem, not part of the solution. By postponing doom into some hypothetical future, these narratives inoculate us against the very real object that has intruded into ecological, social, and psychic space. As we shall see, the hyperobject spells doom now, not at some future date (Morton 103-104).

As contemporary society enters the gravitational field of the hyperobject, it can either pretend it is not there, or it can embrace its time-bending power, realising that it was there all along.

But "tempo" also means weather and, as global warming warps time, it also warps weather. In representing the extremes of global warming, climate fiction higlights one of the key lessons that global warming teaches us: "what we took to be a reliable world was actually just a habitual pattern" (Morton 102). The stable Holocenic climate has enabled humans to develop agrarian societies, because agriculture relies on foreseeable weather patterns, but sedentism would not have been possible during the (relatively) rapid climatic changes that characterised the Pleistocene. As the climate lost its threatening quality, it slipped momentarily to the background. Fast forward to the twenty-first century, human activities are modifying the atmospheric chemistry with a speed and to a degree unseen in hundreds of thousands, and perhaps millions of years-increasing global temperatures and triggering extreme weather events. The weather has ceased to be part of the background that nurtured human activities and has forced its way into the foreground of humanity's awareness. As Morton notes, this change in focus has brought about a painful realisation: 
if the background can suddenly become foreground, then neither exists. He writes: "the strange effect of dragging weather phenomena into the foreground as part of our awareness of global warming has been the gradual realization that there is no foreground" (104). In E poi la sete, drinking water has become rare and precious as an endless drought grips the unnamed European country where the events take place (Montrucchio, E poi la sete 9). When thirst forces humanity to notice its environment, it ceases to be that which surrounds us-the unnoticed, reliable background of human activity - and becomes the foreground, that which cannot be ignored because it threatens us. E poi la sete narrates the far future but, more poignantly, it tells about the author's epiphany:

ogni mattina consumo sei litri d'acqua. Quattro bottiglie.

Non innaffio il giardino.

Mi lavo solo i denti.

Scoprire che un gesto simile richiede tanta acqua farebbe riflettere anche se il pianeta avesse risorse idriche illimitate. Ma non le ha. [every morning I consume six litres of water. Four bottles. I do not water the garden. I only brush my teeth. Finding out that this action requires so much water would make one reflect even if the planet had unlimited water resources. But it does not have them] (Montrucchio, E poi la sete ch. Postilla).

A story about a people suffering due to the lack of water invites readers to become aware of their own water footprint, but dignity is not only about water. Montrucchio contrasts our current condition with that of the wretched characters of the novel, again bringing the issue of the ethical use of resources to the foreground. Just before dying, a character dreams of,

grattacieli, automobili a benzina che rombavano su strade d'asfalto, un telefono in ogni abitazione, donne e uomini biondi che si sorridevano dal fondo degli occhi chiari, abiti di cotone e di lana e di seta, abiti diversi per ogni stagione, quattro stagioni, erba e alberi a costeggiare le vie e perfino - sì, aveva osato sognare questo 
- perfino fontane. Gente che beveva ovunque, acqua ovunque, senza parsimonia, senza leggi per impedirne lo spreco, bambini che si spruzzavano e innamorati che facevano l'amore sotto la doccia e padri di famiglia che annaffiavano il prato [skyscrapers, petrolpowered cars that roared on paved roads, a telephone in each home, blond men and women who smiled from the depths of their pale eyes, cotton and woollen and silken clothes, different clothes for each season, four seasons, grass and trees skirting the streets and even-yes, he dared to dream this-even fountains. People drinking everywhere, water everywhere, without thrift, without laws to prevent its waste, children who sprayed each other and lovers who made love under the shower, and fathers who watered the lawn] (Montrucchio, E poi la sete ch. Dopodomani. Notte fonda).

By foregrounding what was in the background, Montrucchio invites the reader to reflect on the concept of "normality". What is normal for the inhabitants of a developed country today is far from normal for the great majority of humanity: peace, safety, comfort and clean water are invaluable assets that are too often taken for granted. As happens in the Rubin's vase illusion, when foreground and background can easily exchange their position, then these two terms lose their meaning completely: is it a vase or are these two faces? Or both? Or neither? Hyperobjects show us that there is no background or foreground, there is no landscape or environment, no world. "What is left if we aren't the world? Intimacy. We have lost the world but gained a soul-the entities that coexist with us obtrude on our awareness with greater and greater urgency", Morton argues (108). Unlike the millenaristic "end of the world", this is an expansive epiphany that forces the reader into an uncanny intimacy with those who suffer, negating the convenient concept of "away" which underpins much of modernity: pollutants remain with us for millennia until geological processes lock them into rocks, the hyperdimensional nature of hyperobjects means that they will penetrate and hybridise every nook and cranny of civilisation and of humanity: "there is no 'away' in the time of hyperobjects" (112). But if there is no away, 
there is no other that bears the consequences of human recklessness and we are playing a dangerous Prisoner's Dilemma with ourselves.

\subsection{Conclusion}

Global warming offers a stark choice of mitigation, adaptation and suffering: whatever is not mitigated, has to be adapted to, and when adaptation fails, suffering remains. The proportion of each of these elements will be defined by humanity's ability to recognise the consequences of its actions, and act with vision. Whereas schizophrenic compartmentalisation fuels denial, an ability to embrace other points of view is the most precious resource in constructing a just, resilient and harmonious society. Sirene and E poi la sete exemplify how literary writing forces readers to reflect on the role of present society and offers ways to understand the challenges of the Anthropocene. A cynic would argue that these texts are merely fiction, and that fiction does little to change the world. We would do better to ignore such cynical voices. Whereas the era of hyperobjects is a time of inextricable hypocrisy, cynicism is an attempt to rationalise one's hypocrisy and thus it "is the worst hypocrisy: hypocrisy squared, since cynicism is hypocritical about its hypocrisy" (Morton 148). Reading fiction that makes us reflect about our role within the world is a small act of defiance against the dominating paradigm of frontier ethics. Cynical reactionaries "hold that incremental change is a bad thing [but] postponing ethical and political decisions into an idealized future, the critique of incrementalism leaves the world just as it is, while maintaining a smug distance toward it": a comfortable but dangerous proposition in an era of hyperobjects (156). Likewise, it is irrelevant to argue that E poi la sete's predictions of global climate catastrophe sound garish and overstated, or that the ecology of Pugno's mermaids is surreal: escapism feeds on hyperbole, but the narrative of hyperobjects reveals that there is nowhere to escape to, and they lead readers back to reality. Ultimately, it is not the aim of these works to predict the future, but somehow to remind readers that there will be a tomorrow, that we will be there in one way or the other, and that its 
shape is determined by the choices we make today. Most importantly, narrative's "oblique gaze" enables readers to appreciate the higher reality of hyperobjects, allowing them to imagine their dark side, the vast belly of the hyperobject that is about to swallow humanity. Literary writing may be accused of being wrong about the shapes that inhabit the foggy regions of the far future, but only because it dared to imagine them. Far worse would be imagining the hyperobject as an infinite void, or letting cynicism prevent us from imagining at all. 


\section{Chapter 6}

\section{Conclusions}

\subsection{Reviewing Premises and Findings}

As I wrote this thesis, I have met fellow concerned humanists and I have been privileged to have access to the insights of thinkers who provide the critical frameworks that I proposed in my "Literature Review" (section 2.3). I am much indebted to those who have developed the literary current of ecocriticism, and, specifically, the frameworks of "material ecocriticism", "slow violence" and "hyperobjects". Ecocriticism's hybrid approach invalidates any perceived dichotomy between scientific and humanistic thought: matter and text inform each other, flow into each other, reveal contiguous, complementary and cybernetic realities.

But so what? Knowledge without power only produces hopelessness: as significant these insights may be within academia, how do they assert the legitimacy of the Humanities at this critical stage of humanity's evolutionary path? The intuition upon which I base my research is that frontier ethics, materialism, utilitarianism and consumerism are cultural artefacts and, as such, can only be understood and challenged by questioning their cultural supremacy: no technology can uphold ecological justice, or raise awareness of the preciousness of life. So, how can literary writing - the softest of powers-challenge established world-views? Before the above question can 
be answered, it needs to be refined: "literary writing" is an extremely broad concept, which includes anything ever written with the intention of contributing to the human corpus of literature. Thus, in discussing the "Rationale for the Selection of Works" (section 2.2), I identified a small number of parameters that have allowed me to limit my primary literature to a manageable number of texts and, at the same time, to generalise my findings to similar literature. Without specifically rehashing the rationale of my choice, these parameters (relevancy, recency and activism) have been partly moulded after Wu Ming's "New Italian Epic" - a "nebula" of literary texts with similar characteristics, including the rejection of cynical detachment, the adoption of an "oblique gaze" and dissimulated linguistic experimentation. In Wu Ming's intention, New Italian Epic aggregates literary works that subtly challenge the reader, exposing the uncanny aspects of apparently familiar realities. Having restricted my corpus to seven literary texts, I endeavoured to discover how these works question-and perhaps weaken-the world-view that has manufactured the greatest existential challenge that humanity has ever faced. Here lies the true originality of my research: to try and understand - through textual analysis and (where possible) through personal interviews with the authors-not only what the literary texts say but also how they interact with readers. I have shown that ecological issues that are perceived as distant and abstract, such as chemical pollution, land use change and even global warming become more accessible and emotively charged when readers can attach faces to numbers. For example, while reading Ecomafia reports can appeal specialists and experts, experiencing a virtual toxic tour through the "Land of Fires" allows reading citizens to grasp the mechanisms, the size and the consequences of the criminal system that has created it. Similarly, navigating the Niger delta with Tamerlano in Delta Blues exposes readers to the reality of the "resource curse" that destroys the livelihood of millions and vividly introduces concepts related to the framework of "slow violence". And likewise, Sirene's merciless critique of anthropocentrism highlights the flaws of the social paradigm we are immersed in for a readership that is probably unaware of academic debates about hyperobjects, ecocriticism 
and post-humanism.

The conclusions I have reached through the analysis of these texts are as follows: first, I have found that narrative is emotively compelling. By approaching issues from unusual points of view, literary writing enables readers to participate in the characters' hopes, grief, frustrations and rejoicing, eroding the emotional distance between them and narrated events. Second, I have found that narrative makes strangeness accessible. Narrative popularises issues, cuts through governmental and corporative propaganda, paints human faces over anonymous statistics, thus reminding readers about the suffering that spreadsheets cannot fathom. In addition, narrative humanises the formal language of official reports and translates it into a language which its target readers can assimilate more easily. Third - and perhaps most important-I was able to show that narrative is empowering, because it implicitly introduces interpretive frameworks that allow readers to understand complex ecological issues and review unquestioned cultural stances such as frontier ethics, materialism and anthropocentrism. Timothy Morton suggests that "philosophies ... have consequences" (159). Thus, because the causes of the current ecological crisis are to be found in how humanity relates with the other, challenging harmful philosophies that place humans above and beyond other life-forms also challenges the behaviours that these world-views spawn.

\subsection{Looking Forward: Future Directions}

As this journey ends, I find myself midway to another destination, as I realise that each answer I have found leads to multiple new questions: how do Italian science fiction authors imagine the Earth and humanity in the present and in subsequent centuries, and how does their visions compare with the scenarios that social science and climate science offer? What do the accounts of people who have spent extensive periods of time deep in the wilderness tell us about our urbanite lifestyles and about a different way to imagine the living world? How do authorial sensitivities compare with the major challenges that scientists 
identify as the ecological concerns of the Anthropocene? The last question is particularly interesting. In the "Beyond the boundary" chart (figure 1.1), Rockström et al. show that three out of nine planetary boundaries have been crossed: nitrogen flow, biodiversity loss and climate change. Ocean acidity, phosphorous flow and freshwater consumption represent additional causes of future concern. Very little of this is present in Italian literary writing. In fact, during my search for texts which would satisfy the parameters of relevancy, recency and activism, I have noticed that most works focus on chemical pollution and land use change, whereas works which confront climate change, biodiversity loss or ocean acidification-let alone relatively esoteric topics such as nitrogen flow-are few and far between. It is only understandable that authors would prefer to deal with visible and local concerns and shy away from subjects that, because of their own abstract (or, nonlocal) nature, resist visualisation.

However, this is hardly a justification: in fact, who would want a literature of the banal? Literary writing has often courageously confronted the unseen and I would argue that signifying the ineffable is its ultimate goal. Moreover, as I mention in section 5, English and American literature offer a whole genre based on narrating climate change-authors of climate fiction novels have been able to convey very well the human side of global warming. What are the reasons for the notable absence of an Italian literature of the Anthropocene apart from a handful of titles? There is probably no straightforward or satisfactory answer to this question, but my interview with Laura Pugno offers some food for thought:

viviamo un momento in cui il mercato italiano affronta una fase di contrazione e impoverimento, e tutti gli scrittori (consciamente o inconsciamente, esplicitamente o implicitamente) devono fare i conti con questo fenomeno di riduzione delle risorse. Di conseguenza è sempre più difficile confrontarsi con temi che siano potenzialmente difficili o poco appetibili per il lettore. La pressione degli editori porta, magari inconsciamente, gli autori a produrre romanzi contrassegnati da una grande riconoscibilità, spesso declinata in 
senso regionale o locale, e da una volontà di offrire rassicurazione al lettore [we live at a time when the Italian market is experiencing a phase of contraction and impoverishment. All writers (consciously or subconsciously, explicitly or implicitly) must deal with this phenomenon of resource cutback. Consequently, it is harder and harder to confront themes that are potentially difficult or unappealing to readers. The publishers' pressure pushes (perhaps subconsciously) authors to produce immediately recognisable novels that are often rooted in a specific regional or local context and that reassure the reader](Appendix B/Intervista a Laura Pugno")

Pugno warns us of a negative synergy of authorial self-censorship and a conservative publishing market: a combination hardly conducive to facing the uncomfortable fears that creep into our unconscious as we enter the Anthropocene. However, it is also true that risk-aversion breeds banality, and banality breeds disaffection. Series such as VerdeNero and writers such as Alessandra Montrucchio, Tommaso Pincio, Laura Pugno, Roberto Saviano and Antonio Scurati challenge the literary status quo that would rather lull us into an uneasy sleep than let readers and, by extension, society face the Anthropocene.

Even more importantly, through my research I have come to the conclusion that a humanistic approach to understanding the ecological challenges of the Anthropocene would be extremely well-suited for the classroom. In my discussion I have emphasised the benefits of exploring ecology though literature, but vicariously experiencing scenarios of environmental degradation would be especially effective if it could be used within a supportive environment such as a classroom, where discussion and exchange of ideas follows individual reading. Joint environmental and literary studies programmes could be developed using stories able to capture the attention of younger readers as a basis of discussion to introduce topics related to environmental ethics, such as the value of nature and the role of humanity within it. Approaching ecological issues through literature would allow students to deeply experience how ecology and humanity are one and the same, and would provide them with the intellectual 
and emotive tools to learn the importance of caring for what sustains us. In particular, the Millennial Generation that constitutes the bulk of university students as I write is profoundly invested in understanding the Anthropocene in all its facets and their interest in the subject matter is bound to grow: they are the ones who are going to see first-hand either the rapid decarbonisation of the world economy or the global climate breakdown. I am hardly a pioneer: Professor Stephanie LeMenager of the University of Oregon teaches climate change through literature in her course "Cultures of Climate Change", using "films, poetry, photography, essays and a heavy dose of the mushrooming subgenre of speculative fiction known as climate fiction, or cli-fi" to teach postgraduate students "not only about the unfolding crisis but also about adaptations and survival strategies" (Pérez-Peña). There is nothing preventing other universities to embrace this multidisciplinary approach and even extend it to undergraduates. There is nothing but inertia that prevents Italianists from approaching the same themes through the great wealth of imagery that Italian literature provides.

I have often imagined myself as an anatomist. But instead of dissecting organisms to understand the secrets of life, I have dissected narratives to learn about the secrets of making people care about the living world. Specifically, in this thesis I have demonstrated that a number of Italian authors are willing to engage with their readership on a deeper level than mere commercial entertainment. Their works invite readers to take an active role in challenging the dominant social paradigm that would have citizens as passive and ethically inactive consumers. Indeed, as my examples have shown, the act of reading environmental narrative is in itself a subversive act that contributes to corrode the anthropocentric paradigm. Thus, I hope that my readers are now convinced that literary writing allows us to "imagine ways out" exactly because its emotive approach counteracts the cynical reductionism of frontier ethics. 
Appendices 



\section{Appendix A}

\section{Intervista a Jadel Andreetto, Kai Zen}

13 November 2013

Perché avete deciso di scrivere riguardo le conseguenze sociali e ecologiche dell'estrazione del petrolio? Perché il delta del Niger?

Credo l'idea in principio sia venuta a me. Ci siamo trovati con VerdeNero a Milano nell'ufficio del nostro agente. Alberto [Ibba] aveva letto La strategia dell'ariete ed era interessato ad una storia di fantapolitica. Innanzitutto ci ha spiegato cos'era VerdeNero, anche se lo sapevamo già, perché avevamo letto qualcosa, poi ci ha proposto di scrivere un romanzo econoir di fantascienza ambientato in Italia e incentrato sulle fonti rinnovabili. Contemporanteamente, avevo letto un paio di reportage sull'internazionale e avevo letto Nigeria, risorse di chi?. Credo anche che avessimo visto il documentario di Avgeropoulos [Delta, Oil's Dirty Business]. Noi poi non siamo particolarmente interessati a raccontare storie ambientate in Italia, o comunque che abbiano a che fare strettamente con l'Italia, e non trovavamo una chiave di lettura che ci convincesse. Tuttavia, avendo seguito da tempo le questioni del MEND e del delta del Niger, ci ronzava un po' in testa l'idea di un romanzo ambientato in Nigeria.

Dopodiché abbiamo iniziato a spulciare il catalogo di VerdeNero e ci siamo imbattuti in Vite spericolate di Patrick Fogli. La domanda che stava alla base di questo romanzo era, "Cosa succede quando il colpevole non è una persona fisica 
ma una giuridica? Cosa succede quando il colpevole è una multinazionale?" In seguito, durante un incontro dei Kai Zen, da questa domanda, ci siamo trovati a chiederci, "Cosa succede quando, alla fine del giallo, scopro che l'assassino sono io?" Perché in effetti l'ENI in Nigeria sta causando morti, malattie, una piccola apocalisse. Ma l'ENI sono io, l'ENI è una società a partecipazione statale. Cerchiamo di dare una risposta, o almeno cerchiamo altre domande, perché le risposte non le abbiamo.

Da quel momento abbiamo condiviso i materiali ma non avevamo ancora una storia in mano. Siamo però arrivati alla conclusione che quello che stava succedendo non era altro che una forma di colonialismo, anche se il termine più adatto sarebbe neo-colonialismo. E da lì mi è venuto in mente che era un po' di tempo che volevo fare una cover, e ho realizzato che la storia che volevamo scrivere era stata già scritta molto meglio di quello che avremmo mai potuto fare: Cuore di tenebra. Noi abbiamo attualizzato quello che Joseph Conrad aveva scritto. Non siamo certo i primi a fare una cover di Cuore di tenebra. Prima di noi, Apocalypse Now ma anche Aguirre furore di Dio [di Werner Herzog]. Quindi abbiamo deciso di rileggere Cuore di tenebra e di guardarci questi due film.

In Delta blues abbiamo messo insieme diversi registri narrativi e spinto sull'acceleratore dell'avventura per dare ritmo. Il rischio più grosso che stavamo correndo era quello di essere didascalici, di tenere una lezione morale, e infatti abbiamo deciso di dare diversi punti di vista $-\mathrm{i}$ due principali sono quelli di Klein e quello di Tamerlano. Come ne La strategia dell'ariete volevamo evitare di dipingere i personaggi in bianco e nero. In Delta blues, tutti i personaggi sono sul crinale, che non è una scelta facile.

In realtà, questo riflette una contraddizione che tutti viviamo perché come società siamo dipendenti dagli idrocarburi. Quello che volevamo dire non è che dobbiamo rinunciare dall'oggi al domani a queste cose perché là stiamo ammazzando della gente. È chiaro che questo è impossibile. Il rischio per noi era cadere preda del romanzo a tesi, ma le cose sono complesse e ci piace citare Camus quando dice che la coerenza porta ai campi di concentramento. Insomma, un po' di incoerenza ogni tanto non fa male, per cui ci siamo voluti mantenere 
un po' sul crinale. Il messaggio che abbiamo cercato di far passare è che abbiamo bisogno di consapevolezza, cioè sapere che ogni volta che accendo il gas, che compro qualcosa di plastica, o che faccio il pieno alla macchina, o che prendo un aereo, qualcuno dall'altra parte del mondo soffre. Come scrittore, io non posso fare altro, non è che posso andare a combattere insieme ai ribelli del MEND, anche perché nemmeno loro sono proprio trasparenti, molti fanno parte di organizzazioni pseudomafiose, contrabbandieri, narcotrafficanti. Il bon savage non ci convince per nulla, non ci ha mai convinto.

\section{Cosa ha ispirato i fatti e gli eventi che descrivete in Delta blues?}

In Delta blues, alcune cose che sembrano prese da Apocalypse Now sono prese da Cuore di tenebra, alcune cose che sembrano prese da Cuore di tenebra sono prese da Aguirre, alcune cose che sembrano prese da tutte le cose in realtà sono prese da Corto Maltese. Ci siamo divertiti a mettere in scena attraverso il Tamerlano di [Christopher] Marlowe i momenti suoi più intimi, però ci sono anche frasi che mettiamo in bocca a Tamerlano che sono di Corto Maltese, perché Tamerlano è in parte una specie di Corto Maltese, anche se Corto Maltese non avrebbe mai fatto l'agente segreto. Klein è stato chiamato Klein per Kurtz, ma in realtà è stato Conrad a chiamare Kurtz per Klein, perché Conrad conosceva un certo capitano Klein a cui si è ispirato per il personaggio di Kurtz. Nina, la figlia di Klein, è il nome della figlia di Almayer in Almayer's Folly, la prima novella di Conrad. Insomma, Delta blues è pieno di rimandi letterari, come la scelta rispetto a Tamerlano di non chiamare mai nessuno per nome, tranne la figlia di Klein e Marguerite, perché Marguerite era il personaggio che ci serviva per avere uno sguardo più umano. Klein è un genio, ma è pazzo, mentre la coscienza di Tamerlano non corrisponde con quella che potrebbe essere del lettore. Marguerite era lo sguardo che abbiamo avuto noi Kai Zen nel guardare i documentari, cioè la curiositò di andare a vedere, di infilarsi nei casini pur di raccontare questa storia. La nostra scelta di chiamare la società di estrazione petrolifera "Ente" invece di “ENI" è stata una scelta dettata dalla necessità di ripararci da eventuali ripercussioni legali.

In Delta blues, Zainab impersona la voce autorevole della scienza, che fornisce 
a Martin Klein (e al lettore) informazioni riguardanti la situazione ambientale nel delta del Niger. Nella novella, queste informazioni cementano i sospetti di Martin Klein e lo convincono a combattere contro l'Ente. Qual'è il ruolo della scienza nella letteratura? In che modo queste due aree dello scibile umano interagiscono? Qual'è il ruolo della letteratura nel superare la mancanza di consapevolezza verso le conseguenze del consumismo e della dipendenza dai combustibili fossili?

Questo romanzo è stato pensato in quattro, poi scritto da me e da Guglielmo, ma è stato Guglielmo ad ideare il personaggio di Zainab. Guglielmo si è documentato a lungo per poterla scrivere, anche se è chiaro che non potevamo metterle in bocca troppa roba perché sarebbe diventato noioso. L'idea alla base del personaggio era di inserire un personaggio che potesse spiegare la situazione senza appesantire il romanzo, quindi abbiamo scelto un personaggio secondario: se l'avesse fatto Klein sarebbe stato noiosissimo, oltre a non rientrare nella sua psicologia.

Zainab è un pò la controparte di Marguerite. Marguerite è un po' lo sguardo dell'europeo che guarda queste cose con una certa coscienza, Zainab è invece lo sguardo interno su quello che succede, che ci si aspetta dovrebbe essere molto più appassionato, e invece è distaccato e cinico perché vive lì dentro, mentre Marguerite è più appassionata perché vede la situazione da fuori e forse si sente in colpa.

Poi, Delta blues affronta la questione dell'altro, che è una questione noi Kai Zen sentiamo molto dato che due di noi sono di Bolzano. Sia Martin Klein sia Tamerlano appartengono a terre di confine. Ivo Andric̀, il vero nome di Tamerlano, è quello di uno scrittore bosniaco-croato che ha scritto il libro Il ponte sulla Drina, la storia di un ponte che unisce due paesi, uno cristiano e uno musulmano. Martin Klein è di Merano, anch'essa terra di confine tra l'Italia e l'Austria. Dicevo, a Bolzano esiste un monumento fascista che riporta la scritta "Siamo venuti qui a civilizzare i barbari con le arti e con la lingua", che ha fatto pensare alla questione dell'alterità. Mettere dei personaggi provenienti da terre in cui il confronto con l'altro (per esempio Slovenia e Alto Adige) è palese ci 
permette di rappresentare il confronto che avviene nella vita di tutti i giorni in modo nascosto. Noi come cittadini del mondo sviluppato non abbiamo percezione di ciò che stiamo facendo all'altro, in questo caso la Nigeria, quando compiamo quotidianamente azioni a prima vista insignificanti come accendere il gas o fare il pieno alla macchina, perché non abbiamo alcuna consapevolezza della catena che sta dietro a queste azioni. Ma il problema è che l'altro sono io, perché nella maggior parte del mondo la gente vive in quelle condizioni e non è un caso che in Delta blues ci sia una citazione da Cronache anarchiche che dice che "nella maggior parte del mondo, l'uomo non ha altro che fame, un fucile e forse una religione". Questa è una riflessione che mi è venuta perché due anni prima di scrivere Delta blues ho fatto un reportage da una favela in Argentina, che mi ha dato per la prima volta in vita mia la nozione che l'altro fossi io. Quella che ho visitato è stata una favela in cui vivono trentamila persone in condizioni allucinanti, in cui la vita non vale nulla, e ho avuto l'impressione di essere io quello fuori posto, perché la maggior parte del mondo è così e siamo noi quelli fuori posto. Ecco, in questo senso forse l'unica cosa che siamo forse parzialmente riusciti a fare in Delta blues è stato fornire un punto di vista altro, quello di Zainab, perché gli altri inevitabilmente sono punti di vista nostri.

Anche Klein che, se vuoi, passa dall'altra parte, comunque, come in Cuore di tenebra, è l'uomo bianco con gli adoratori neri intorno anche se le cose sono molto cambiate. Non so se hai notato che in Cuore di tenebra il negro non parla mai, non ha coscienza, è una specie di oggetto. Quando abbiamo scoperto chi sono alcuni dei capi del MEND, al di là della loro immagine coreografica, in realtà sono scienziati, ingegneri, architetti. Anche qui c'è un ribaltamento delle aspettative: il neo-colonialismo ha a che fare con il neo-colonizzato che non è più tanto disposto a farsi colonizzare, vuoi per ideale o per interesse. Il negro di Delta blues è molto diverso da quello di Cuore di tenebra: abbiamo voluto evitare il cliché del bon savage ma anche raccontare che le cose sono complesse.

\section{Dove ponete Delta blues all'interno del New Italian Epic?}

Diciamo che il lavoro fatto da Roberto [Bui] sia interessante, soprattutto per un pubblico non italiano, per aiutare a capire cosa sta succedendo. Credo che 
abbia sistematizzato qualcosa che non è sistematico, cioè il New Italian Epic è un movimento spontaneo, non è organizzato, ed è già morto come lo stesso Roberto dice. Identifichiamo Delta blues all'interno del New Italian Epic perché alcuni parametri corrispondono al tipo di lavoro che abbiamo fatto fin qua. Delta blues si inserisce in una gruppo recente di opere che guardano al colonialismo italiano, all'Africa italiana, si veda L'ottava vibrazione di Lucarelli, Timira di Wu Ming 2, e anche Camilleri sta guardando in quella direzione. Noi siamo gli unici che l'hanno fatto sull'Africa contemporanea e l'Italia contemporanea, me è curioso che ad un certo punto si inizi a farsi le medesime domande, e forse sarebbe interessante fare un lavoro simile al New Italian Epic in questa direzione. Tornando a Delta blues, però se mi chiedi se questa sia una scelta che abbiamo fatto, la risposta è no, ci siamo mossi spontaneamente in una certa direzione.

Nella mia tesi voglio mostrare come la narrativa possa essere utilizzata per creare consapevolezza riguardo a temi ambientali e porre domande di natura etica riguardo il nostro modello di progresso. I testi letterari sarebbero usati come casi studio per innescare una discussione su quale modello di sviluppo sia il più desiderabile e su concetti di etica ambientale. Vuoi commentare? Trovi che utilizzare testi letterari in questo modo sia possibile o desiderabile?

Come al solito ti dò due punti di vista. Da una parte sì, altrimenti non l'avrei fatto, cioè nel senso che contribuisce alla consapevolezza, non a cambiare le cose perché poi i numeri sono quello che sono rispetto a chi ti legge. Però il sapere che fai parte di una compagnia statale che fa quello che fa a me non va tanto bene, e scrivendo Delta blues l'ho scoperto ulteriormente e ha contribuito in me a cambiare alcune abitudini quotidiane. Credo che questo la letteratura possa farlo, e molto più che la saggistica. Abbiamo scelto un registro avventuroso proprio per poter veicolare senza troppo nozionismo e senza troppa pesantezza un messaggio, poi c'è [alla fine di Delta blues] una bibliografia che consente al lettore di approfondire. D'altro canto mi chiedo anche quanto non stiamo predicando ai convertiti, nel senso che chi compra il VerdeNero di Kai Zen o di Wu Ming è fondamentalmente già d'accordo con noi. È possibile che queste cose non le sappiano o le sappiano vagamente e vogliano approfondirle attraverso la 
lettura dei nostri libri. Se un libro del genere lo scrivesse Fabio Volo, allora forse sposterebbe qualcosina in più, anche se poi dubito che ci sarebbero cambiamenti radicali. Per esempio secondo me hai fatto bene ad inserire nei testi che studi quello di [Licia] Troisi, perché lei ha accettato questa sfida ed è stata in grado di riprodurre quello che il suo pubblico di riferimento vuole, inserendo nella sua opera un po' di pensiero etico. Poi io non so se lei si è limitata a fare il compitino a casa o se si è messa a studiare quanto abbiamo studiato noi, ma questo non è importante. 


\section{Appendix B}

\section{Intervista a Laura Pugno}

18 November 2013

\section{Perché hai deciso, in Sirene, di parlare della fine dei tempi?}

In realtà non ho deciso di "parlare della fine dei tempi", e non ho scritto Sirene, il mio primo romanzo, per fare in sé opera di ecologismo militante. Nella mia opera, tra il piano della militanza (parola su cui bisogna intendersi e che meriterebbe molte riflessioni) e quello della scrittura (e anche qui ...), è senz'altro dominante il secondo - il che non significa cedere all'estetismo, ma nemmeno all'arte, diciamo, didattica. Significa piuttosto mantenersi in equilibrio su una corda tesa. Ciononostante sono, come cittadina prima che come scrittrice, sensibile a temi che sono temi del mio tempo. Credo che gli scrittori siano un po' come dei radar rispetto al proprio tempo, che intercettano tematiche che in qualche modo sono nell'aria. Il romanzo di ricerca - fatto per fare letteratura e non semplicemente per rispondere a una domanda commerciale - si avvicina ai temi che in una determinata epoca sono tabù quando si avvicina la possibilità di un loro superamento. Se guardiamo la storia del romanzo contemporaneo [moderno], un romanzo come Jude l'oscuro [Jude the Obscure] di Thomas Hardy è il prodotto di un momento in cui l'idea di scegliere il proprio destino intellettuale è in contrasto con un ordine sociale precostituito, con ceti o classi rigide, e l'idea di scegliere il proprio destino 
sentimentale emerge in maniera eversiva in una società la cui struttura sociale è basata sul matrimonio come contratto irreversibile. (Il tema dell'amore romantico che sarà di tutto il romanzo ottocentesco). Allo stesso modo, oggi l'idea del confine di specie appare diversa dal modo in cui poteva apparire trent'anni fa, perché parliamo di cellule staminali, perché emergono questioni su cosa sia umano e cosa non lo sia, cosicché non riusciamo più a godere di un antropocentrismo tranquillo. Così, nonostante io non corrisponda all'identikit classico dell'ecologista militante, sono sensibile a questi che sono i temi di oggi, visto che oggi dobbiamo continuamente confrontarci con l'idea di apocalissi nei mass media, nella letteratura, e nella nostra quotidianità. Ci sarebbe da chiedersi semmai perché non ci siano più scrittori che si occupano di queste tematiche. In realtà, probabilmente ho una qualche predisposizione a trattare tematiche estreme, e anche a descrivere paesaggi estremi. Per esempio, in Quando verrai, che tocca temi come l'adolescenza e la morte in un contesto molto meno futuribile di quello di Sirene, il delta del Po è incendiato dai rifiuti tossici. Anche se non sono una scienziata e non ho una formazione scientifica, vedo filtrati nella mia opera e nella mia immaginazione gli scenari apocalittici che la scienza oggi come oggi ci porta. Questo mio interesse per la scienza, che si estende alle possibili affinità tra la fisica quantistica e la poesia, potrebbe essere dovuto al fatto che la mia formazione culturale è avvenuta non solo in Italia ma in Europa (soprattutto Gran Bretagna ma anche Francia, Belgio e Spagna). In realtà non credo di corrispondere molto al classico profilo del letterato/a italiano/a. Forse l'apparente mancanza di sensibilità scientifica ed ecologica nella letteratura italiana riguardo ai temi ambientali è causata dalla separazione - che si dà nella nostra società prima ancora che nella letteratura - tra cultura letteraria o umanistica e cultura scientifica. Le due cose raramente si incrociano e ancora più raramente riescono a stabilire un dialogo fruttuoso, dato che molte volte gli umanisti tendono ancora, nonostante tutto, a guardare gli scienziati dall'alto al basso e chi pratica le discipline scientifiche è oggi meno dotato di cultura umanistica di un tempo. Per questo, l'Italia rimane un'anomalia rispetto ad altri contesti come la Francia o l'Inghilterra, dove le due culture si interfacciano 
maggiormente e si produce una maggiore ibridazione nell'immaginario degli scrittori. Va anche detto che viviamo un momento in cui il mercato italiano affronta una fase di contrazione e impoverimento, e tutti gli scrittori (consciamente o inconsciamente, esplicitamente o implicitamente) devono fare i conti con questo fenomeno di riduzione delle risorse. Di conseguenza è sempre più difficile confrontarsi con temi che siano potenzialmente difficili o poco appetibili per il lettore. La pressione degli editori porta, magari inconsciamente, gli autori a produrre romanzi contrassegnati da una grande riconoscibilità, spesso declinata in senso regionale o locale, e da una volontà di offrire rassicurazione al lettore. Al contrario, un romanzo che tratti il tema del riscaldamento globale porta tutto tranne che tranquillità al lettore. Un romanzo di questo genere comporta, per lo scrittore o la scrittrice, un rischio elevato. Fare la neoavanguardia in un contesto di boom economico è molto più facile, perché si tratta di un momento di opportunità crescenti in una società ancora incline a riconoscere il valore della letterarietà. In questo momento, la letterarietà non è merce tanto pregiata, e la comunicazione sull'oggetto-libro in Italia tende a concentrarsi sull'autore come personaggio. Sono quasi banalità oggi, ma vent'anni fa nelle Università si parlava della morte dell'autore. Nel frattempo, l'autore ha fatto di tutto tranne che morire ed al contrario è diventato il principale criterio di vendibilità di un libro.

\section{Quanto ti ritrovi nel concetto di New Italian Epic?}

Secondo me la letteratura è sempre su un crinale, dove da una parte c'è l'estetica e dall'altra l'etica. Non può permettersi di cadere né da un lato né dall'altro, quindi non può diventare puro divertissement ma nemmeno farsi portabandiera della rivoluzione. Il che non vuol dire che la letteratura non sia politica, perché lo è, profondamente, come qualsiasi atto umano. Non credo allo stare disimpegnatamente, passivamente, al mondo; non credo a questa versione del postmoderno che sostiene che la storia sia già stata scritta. Questa è una visione che viene quotidianamente smentita dai fatti. Il mondo è prima di tutto un fatto fisico e biologico, esistono il corpo, il deterioramento del corpo, l'invecchiamento, la morte. Esiste il ciclo della vita a livello non solo 
individuale, ma planetario. D'altra parte, se è vero che ogni scrittore/scrittrice è portatore di un'ideologia, di convinzioni, di una sua moralità, di una sua etica, questo non significa che i suoi personaggi debbano diventare burattini di quell'etica, altrimenti si finirebbero col creare solo opere molto meccaniche. Del resto è un classico della cattiva letteratura... L'etica è un concetto che lo scrittore adopera su di sé e sul mondo; però non credo vi sia una completa coincidenza tra l'etica dell'autore e l'opera, anche perché spero che la mia opera sia migliore di me. Abbiamo sempre una visione del mondo che filtra le nostre percezioni, ed è impossibile essere filtri neutri ma quello che "filtra" nella scrittura non è così automatico... L'aspetto estetico e quello etico della scrittura sono indissolubilmente intrecciati, come la spirale del DNA, e questo è vero anche per ideologie intollerabili: come nel caso di [D.W.] Griffith, un grandissimo regista e, allo stesso tempo, un sostenitore dello schiavismo. Senza dubbio è un cammino ricco di insidie, ma devo dire che l'immagine del crinale mi aiuta. In un certo senso è anche troppo facile oggi ritrovarsi a credere che la letteratura sia disimpegno e che non debba essere militante, e qui con militanza intendo avere un concetto dell'umano. La letteratura è una forma di telepatia: entrare nella testa delle persone può in qualche modo contribuire a cambiarle, a livello molto profondo. Trovo che il rapporto tra questi due livelli dell'opera sia molto, molto complesso: le opere che continuiamo a leggere sono quelle che riteniamo eticamente accettabili ed esteticamente belle, altrimenti tendiamo a rimuoverle. Fondamentalmente non è possibile liberarsi di questa tensione e fare esclusivamente dell'opera il vessillo dell'idea come Aristotele credeva che il corpo femminile fosse solo il veicolo della materia. Può essere provocatorio affermare la necessità di un'etica della letteratura in un epoca in cui la tendenza va in senso contrario, così come la tendenza dell'arte per l'arte è nata in un epoca in cui si riteneva che l'arte dovesse avere fini ideali o morali.

In Sirene affronti il tema della natura umana e più specificamente del rapporto dell'umano con l'altro, sia in termini sessuali sia di specie. Qual'è secondo te il ruolo della letteratura nel superamento di queste barriere?

Sono molto affascinata dalla paleoantropologia, ho letto diverse cose sullo 
argomento e anche scritto una pièce teatrale. Nel folklore umano, l'umanità non è mai sola: ci sono fate, streghe, mostri, semidèi. Abbiamo sempre a che fare con un Altro che non è umano e il nostro passato ci informa che anche in termini evolutivi è stato così. Abbiamo convissuto con diversi ominidi, altre specie umane leggermente diverse - con cui a quanto pare, secondo gli ultimi studi, ci siamo anche incrociati - il che dimostra che l'evoluzione è tutt'altro che un procedere lineare da una forma scimmiesca ad una forma perfetta. E' una storia molto più complessa. Dato che quando queste interazioni sono avvenute eravamo già esseri in grado di produrre cultura, da qualche parte c'è probabilmente una sorta di relitto mnestico con cui dobbiamo fare i conti, quindi l'Altro è da sempre la domanda che ci portiamo dietro, non importa se animale o umano. La nostra umanità si forma nell'educazione e nell'ambiente e l'essere umano che non viene esposto in tenera età alla compagnia di esseri umani non solo non si socializza, ma non sviluppa le proprie potenzialità di essere umano. Non impara a parlare. Dov'è allora la sua umanità? La cultura è qualcosa in cui veniamo immersi e che ci forma a livello profondo, quindi l'Altro è un problema inevitabile e ineliminabile, ma è vero che negli ultimi venti o trent'anni c'è stata una certa sensibilizzazione culturale anche in Italia su dove esattamente siano i confini dell'umano, se siano fissi o se si spostino di epoca in epoca, e che cosa includano e cosa lascino fuori. Ritorniamo al tema dell'antropocentrismo tranquillo: in realtà continuiamo a essere antropocentrici, però non riusciamo più a goderci l'antropocentrismo beatamente, e questo significa che c'è un riconoscimento della dignità e di capacità di sofferenza di ciò che non è umano. Non so quanto la letteratura sia stata forza trainante in questo processo di sensibilizzazione. Mi pare che questo tipo di immaginazione sia stata suscitata non solo da immagini ma anche da scritti, ma non necessariamente da quelli che noi rubricheremmo come scritti letterari: mi pare che sia stata più la divulgazione scientifica a fare questo, e che la letteratura abbia forse più ricevuto che generato i segnali del cambiamento del tempo. È poi vero che molte volte questa distinzione è sottile. Ci sono opere che da scientifiche vengono in seguito assunte nel corpus letterario a prescindere dall'intenzione originale dell'autore, in cui scienza e 
letteratura sono piani parzialmente sovrapposti. Però torniamo a dire che in Italia esiste una dicotomia tra discorso scientifico e discorso letterario. Questo mi dà l'opportunità di introdurre il tema del fantastico e del genere, problematiche che io trovo piuttosto noiose e, a dirla tutta, in fondo in fondo estranee alla mia opera. Io sono del tutto disinteressata al genere salvo come strumento di analisi. Quello che faccio rientra nella letteratura tout court, la letteratura bianca se il bianco è l'assenza di colore. Poi se vogliamo perimetrare questa letteratura al suo interno è un conto, ma pare che i confini dell'immaginario ultimamente siano così ristretti che qualsiasi cosa sfori di un po' dal territorio del realismo duro e puro diventa un oggetto-letterario non-identificato che deve essere rapidamente ricondotto nella propria nicchia. Per me scrivere in modalità realistica o fantastica è la stessa cosa: non percepisco un cambio di passo, fa tutto parte dello stesso insieme.

In Sirene, la Yakuza tenta continuamente di dominare la natura attraverso la scienza. Qual'è il ruolo della scienza nella letteratura? Come interagiscono e qual'è il ruolo della letteratura nel rendere evidente la mancanza di consapevolezza riguardo gli effetti dannosi dell'antropocentrismo?

Dal punto di vista morale, la risposta è quella che ti ho dato prima, e cioè che la letteratura non è necessariamente investita di una mission ecologica o ecologista. In Sirene anche questi contenuti concorrono a creare l'opera ma mi staccherei dall'immediata militanza per rientrare nel concetto del letterario contemporaneo, cioè del libro che appartiene al proprio tempo. Per quanto riguarda il rapporto tra scienza e letteratura all'interno del romanzo non vorrei dare della scienza un'immagine negativa. Non credo assolutamente che la scienza sia solo sopraffazione del vivente. La Yakuza usa la scienza come uno strumento ma, per esempio, anche Samuel, il protagonista, utilizza le proprie conoscenze tecniche - la conoscenza approfondita della strumentazione manuale delle vasche - per salvare la sirena mezzoumana e così investire di significato la propria morte, un fatto non triviale durante un'apocalissi. In circostanze disperate, la forma di conoscenza di cui dispone gli permette, se non di salvare se stesso, di salvare comunque qualcosa. Quindi la scienza non 
ha per me valore negativo, e allo stesso tempo, non va neanche divinizzata. Tra l'altro io ho anche molto timore di certe ondate di pensiero anti-razionalistico o anti-scientifico. Al contempo, però, bisognerebbe saper evitare gli abusi di tecnologie di cui non abbiamo completo controllo. (Più facile a dirsi che a farsi). Resta valido il principio di Hume: una prescrizione normativa non può essere fatta discendere da un set di frasi descrittive. Da tempo, inoltre, la scienza ha iniziato a somigliare sempre di più alla letteratura: le certezze fisse della meccanica newtoniana sono diventate probabilità, qualsiasi cosa voglia dire. Il positivismo ormai è un ricordo e la fisica quantistica dipinge un mondo completamente diverso da quello che ci appariva un tempo. Certo, rimane la domanda di come sia possibile tradurre il pensiero matematico in linguaggio letterario, ma è indubbio che scienza e letteratura siano oggi molto più vicine di una volta. Questa rivoluzione ha rimesso in discussione la nostra stessa capacità di immaginare.

\section{Qual'è invece il ruolo della morte in Sirene?}

Ho scritto Sirene a trentacinque anni, prima di attraversare quella linea d'ombra che consiste nella perdita di qualcuno che ti è caro. Quindi la mia visione della morte ai tempi di Sirene era quella di un'immortale, che non ha mai sperimentato il lutto di persona. (Vedi la serie Gilgames nella mia ultima raccolta di poesia ad oggi, La mente paesaggio). Sirene, che è un libro in cui la morte è onnipresente, non è un libro del lutto. Ed è anche un libro d'esordio, che ai miei occhi oggi ha forte il contrassegno della giovinezza, di ciò che è avvenuto prima dei trentacinque anni. Però allo stesso tempo è vero che la morte è presente, in modi diversi, in tutti i libri che ho scritto e forse non può non esserci perché è da sempre uno degli ingredienti fondamentali della letteratura. La letteratura è quanto di meglio possediamo per avvicinarci, sempre asintoticamente, a quel tipo di conoscenza che non possiamo altrimenti trasmettere. La conoscenza della morte, per esempio, finché non la sperimentiamo nella carne di qualcun altro prima che nella nostra. La letteratura e l'arte riescono a trasmettere quella dimensione umana di cui tutti noi facciamo esperienza e che altrimenti non è condivisibile. Andando a chiudere, dobbiamo forse interrogarci sul 
fatto che siamo l'animale simbolico. Quale sia la funzione di questo uso della simbologia non lo sappiamo, ma sappiamo che serve a qualcosa e forse non è tanto importante sapere, quanto continuare a utilizzare questa capacità. 


\section{Appendix C}

\section{Intervista a Wu Ming 2}

26 November 2013

\section{Perché avete deciso di scrivere per VerdeNero?}

In realtà, è stato l'editore [Alberto Ibba] a contattarci direttamente poiché aveva letto altri nostri articoli e scritti di denuncia rispetto a crimini contro l'ambiente e credo anche il romanzo cui Previsioni del tempo è una specie di sequel di Guerra agli umani. VerdeNero ci ha proposto di scrivere riguardo alle ecomafie e in particolare a noi interessava la questione dei rifiuti anche perché Wu Ming 3 era di Napoli e aveva un legame particolare con la questione dei rifiuti e perché di questa questione me ne ero occupato anche in Guerra agli umani, che descriveva anche traffici di ditte del Nord Italia che sversano nel Sud materiali nocivi. A noi ha sempre interessato, da un punto di vista letterario, l'idea di partire da un documento e trasformarlo in una narrazione, quindi così come abbiamo fatto nei nostri romanzi più classici che sono romanzi storici, c'è sempre un archivio di partenza, non c'è mai una storia o una trama completamente inventata ma è sempre la letteratura e la narrativa, più in generale, che operano una trasformazione su un archivio. Questo ci sembrava una proposta che andava nella stessa direzione: Edizioni Ambiente ci proponeva di fornirci anche dei materiali di studio sulla questione dei rifiuti che noi avremmo potuto consultare, di mettere in fondo al libro riferimenti a ricerche di 
Legambiente e di altre realtà sulla questione dei rifiuti, e quindi ci sembrava che fosse nelle nostre corde questa rielaborazione narrativa di un dato non fittizio. Però non avevamo mai provato a lavorare con un archivio contemporaneo e specifico di un certo settore, in precedenza era sempre stata un'operazione fatta sulla storia e volevamo invece sperimentare lo stesso tipo di atteggiamento su un documento, un archivio. L'elaborazione del libro è certamente stata meno stringente sui documenti di partenza di quanto non facciamo con i nostri romanzi storici che veramente diventano rielaborazioni narrative dell'archivio che mettiamo insieme in anni di ricerca, invece lì la lettura dei documenti è stata propedeutica, però poi non c'è stato, diciamo, un tenere di fianco i documenti: nel momento in cui si scriveva il testo, i documenti sono stati messi da parte e poi si è scelto di andare a pescare quell'altro testo che apparteneva alla storia del collettivo, e cioè Guerra agli umani e di svilupparne una specie di sequel.

In realtà poi, dopo una discussione collettiva, alla stesura di Previsioni del tempo hanno collaborato in maniera pressoché autonoma Wu Ming 3 e Wu Ming 5, salvo poi farci leggere delle parti di ciò che stavano facendo, ed è poi stato riletto ed editato collettivamente. Previsioni del tempo è stato uno di quei progetti non a ranghi completi del collettivo Wu Ming ma nemmeno un progetto solista. Il testo è stato firmato Wu Ming perché quando facciamo una cosa che, pur non essendo a ranghi completi, non è nemmeno un progetto individuale, pare ridondante elencare singolarmente i vari autori. Tra l'altro mi interessava anche vedere come altri avrebbero trattato i personaggi che avevo messo sulla pagina, quindi ho deciso di non partecipare personalmente alla stesura. Poi, la dimensione del testo che ci veniva richiesto non era paragonabile all'impegno sui romanzi storici che richiedono tre o quattro anni di ricerche e di stesura, e quindi ci è sembrato fosse meglio lavorare a ranghi ristretti, anche perché gli altri tre del collettivo avevano fatto e seguito progetti solisti e laterali, mentre $\mathrm{Wu}$ Ming 3 e Wu Ming 5 erano rimasti senza un progetto specifico per le mani.

\section{Situeresti Previsioni del tempo alla periferia, al centro, completamente al di fuori della nebulosa del New Italian Epic?}

Da un lato, sicuramente Previsioni del tempo ha alcune caratteristiche della 
nebulosa che abbiamo chiamato New Italian Epic, per esempio quelle che riguardano lo sguardo obliquo, essendo un racconto che affronta la tematica dei rifiuti attraverso lo sguardo di questo ragazzo che ha da un lato competenze perfettamente legali per fare un lavoro di "stoccaggio" dei rifiuti, solo che lo fa al servizio della malavita organizzata. Ci sembrava che, al tempo, questa fosse una prospettiva particolare, anche tenendo in considerazione che Previsioni del tempo è stato scritto prima di Gomorra. Poi, Previsioni del tempo risponde a quell'aspetto di responsabilità etica da parte del narratore, che in qualche modo si contamina, si sporca le mani e si impegna con il materiale che sta raccontando dove, in qualche modo, il raccontare è prendere posizione consapevole. Quindi, nonostante ci siano episodi rocamboleschi e buffi, non c'è distacco rispetto alla materia che viene raccontata. C'è un po' anche l'aspetto transmediale in quanto, nonostante il medium sia lo stesso di Guerra agli umani, l'editore e il progetto sono differenti e si riprendono personaggi di Guerra agli umani per farli confluire all'interno di Previsioni del tempo. Quindi non collocherei questo testo al centro della nebulosa del New Italian Epic anche perché, dal punto di vista del respiro epico, Previsioni del tempo non è un romanzo ma una novella. Infatti avevamo dei dubbi riguardo alla sua pubblicazione con Einaudi perché ci sembrava che all'interno di VerdeNero avesse una sua collocazione, mentre la pubblicazione con Einaudi insistesse più sulla veste di romanzo che per noi non aveva, era più un racconto lungo. Forse la dimensione etica era meno forte, meno sentita, anche per lo sviluppo della storia stessa e però in Previsioni del tempo esiste quest'idea del narrare come mezzo per porre delle questioni, per interessare e coinvolgere i lettori. Il fatto che, nell'edizione di Edizioni Ambiente in fondo fossero indicati materiali e ricerche sui rifiuti era un invito al lettore per andare oltre, che è un'altra delle caratteristiche tipiche che si riscontra nei titoli di coda dei nostri romanzi storici.

Tutti i personaggi di Previsioni del tempo sembrano soffire di disturbi mentali e nevrosi. Qual'è la relazione tra malattia mentale, criminalità e degradazione del territorio?

Il collegamento è più tra la degenerazione mentale e il meccanismo del 
capitale. Tra le righe, Previsioni del tempo cerca di passare l'idea che in fondo il capitalismo perfetto diviene mafia, cioè che l'impresa capitalistica criminale è per certi aspetti l'impresa capitalista perfetta, in cui non ci sono sindacati né una controparte dei lavoratori, tutto trova il suo posto senza particolari problemi etici e in fondo tutto può avvenire dietro le quinte del denaro che fa da grande sipario. Però i contraltari di questo capitalismo perfetto sono, nel libro, la devastazione ambientale, perché conservazione e rispetto dell'ambiente naturale e dispiegamento del capitalismo ci sembrano due cose che non possono andare d'accordo e nel dispiegarsi perfetto e mafioso del capitale, questo si verifica. Dall'altra parte anche salute mentale e dispiegamento totale del capitalismo ci sembrano due cose incompatibili. In un sistema capitalistico perfettamente dispiegato, lo sfruttamento dell'uomo sull'uomo anche non evidente o diretto è comunque talmente elevato che è inevitabile che tutti coloro che partecipano a quell'impresa siano persone con dei disturbi di natura neurologica. Quindi il collegamento esiste nel senso che sono entrambe conseguenze di questo capitalismo perfetto pur non essendo in rapporto diretto tra di loro ma, piuttosto, ciò che provoca la devastazione ambientale provoca anche la devastazione mentale e quindi queste due cose vanno di pari passo e finiscono per essere aspetti dello stesso problema.

Nella mia tesi voglio mostrare come la narrativa possa essere utilizzata per creare consapevolezza riguardo a temi ambientali e porre domande di natura etica riguardo il nostro modello di progresso. I testi letterari sarebbero usati come casi studio per innescare una discussione su quale modello di sviluppo sia il più desiderabile e su concetti di etica ambientale. Vuoi commentare? Trovi che utilizzare testi letterari in questo modo sia possibile o desiderabile?

Io credo molto nella possibilità della narrativa di essere uno strumento di consapevolezza e di presa di coscienza, quindi sicuramente penso di sì. Ovviamente, dire questo è dire ancora troppo poco, cioè significa da un lato non condannare la narrativa come strumento di pura e semplice manipolazione e nascondimento della realtà ma io credo che la narrativa possa essere anche uno strumento per dire cose che i dati puri non riescono a dire, far parlare i fatti in 
un certo modo e, di conseguenza, mettere in ordine gli avvenimenti in modo che acquisiscano un certo significato. Narrare è sempre mettere in ordine e questo mettere in ordine è dare un significato agli eventi, quindi ovviamente dare un significato agli eventi permette di leggerli e interpretarli e quindi, secondo noi, aumenta la consapevolezza.

Tuttavia credo che questo non basi e debba essere accompagnato da alcuni accorgimenti senza i quali anche la narrativa mossa da buone intenzioni, che rischiano anche di essere un aggravante, può essere manipolatoria. Credo che un narratore si debba sempre interrogare sugli effetti della necessaria attività di selezione che il narrare comporta: il narratore sceglie di raccontare alcune cose, altre di non raccontarle e di raccontarne altre in un modo diverso. Il narratore dev'essere consapevole del fatto che, tra i suoi contenuti, non ci sono solo fatti ma anche le emozioni e l'emotività del lettore, quindi la narrazione è a rischio di manipolazione.

Quali sono dunque gli accorgimenti che un narratore deve adottare? Da un lato deve cercare di costruire con i pezzi che uno mette dentro la narrazione delle strutture fatte come con i mattoncini del Lego, cioè delle strutture nelle quali il lettore veda qual'è il principio di composizione, cioè come sono state realizzate. Queste sono narrazioni che, senza per forza portarti nel backstage, dichiarano molto bene il punto di vista dal quale vengono raccontate. In narrativa, l'onestà intellettuale non è l'equidistanza o la neutralità come forse potrebbe essere nel giornalismo, anche se non so se potrebbe esserlo nemmeno lì.

Nel nostro mestiere di narratori, credo che l'onestà intellettuale stia nel dichiarare il punto di vista, far vedere molto chiaramente il punto di vista dal quale si sta raccontando perché raccontare non si può fare senza un punto di vista: è esattamente guardare le cose con una certa prospettiva, una certa angolatura. Se io dichiaro questa prospettiva, allora anche una narrazione necessariamente parziale può diventare utile per tutti. In politica, la narrazione femminista è una narrazione che acquista un punto di vista molto preciso ma, proprio perché lo dichiara, diventa una narrazione che non è utile soltanto a chi quel punto di vista lo condivide ma che diventa utile per tutti, anche per chi 
ha uno sguardo fisicamente ed inevitabilmente maschile sul mondo, proprio perché descrive quello che pensa l'altra metà del cielo. Quello che ha fatto la stagione dell'operaismo, cioè il guardare le problematiche dal punto di vista di una determinata classe sociale. Fare il contrario sarebbe disonesto, è l'operazione che fa [Giampaolo] Pansa nel Sangue dei vinti, il presentare una narrazione totalmente di parte e parziale come onesta ed equanime.

Quindi narrazione come struttura che il lettore stesso sarà in grado di smontare, non come un bel monumento ben tornito che non mostra le sue crepe ma come una costruzione che mostri i propri punti di sutura. Questo è possibile anche farlo fuori dalla narrazione stessa e io credo sempre di più che romanzi e racconti che abbiano come obiettivo aumentare la consapevolezza del lettore debbano accompagnarsi a materiali collaterali che siano presentati come parte di tutta l'esperienza di lettura, materiali che aiutino il lettore a capire quali sono le modalità di costruzione della storia che ha sentito raccontare per mettere in dubbio le proprie modalità di rappresentazione, quelle con cui finora ha visto il mondo. Questo lo fanno nei nostri ultimi romanzi storici i titoli di coda in cui, capitolo per capitolo, si rivendicano le fonti utilizzate, informazioni sulle origini dell'episodio, eccetera.

Allo stesso modo, dichiariamo dove abbiamo colmato buchi con una nostra invenzione perché la narrativa è un metodo di indagine dalla realtà che ogni tanto ha bisogno, per capire meglio il senso di una vicenda, di inventarne dei pezzi. Se questo viene segnalato, credo sia uno strumento di ricerca interessante. Nei nostri ultimi romanzi solisti, Point Lenana e Timira, ci sono trenta o quaranta pagine di titoli di coda che non sono né un modo per far vedere quanto uno abbia studiato e quanto sia stato bravo né sono delle vere e proprie note ma è un corredo che si fornisce al lettore per invitarlo ad esplorare l'universo narrativo che l'autore ha esplorato e per farsene un'idea.

Questo mi ricorda quello che scrive Paul Veyne, un filosofo francese, in un libro che si chiama I greci hanno creduto nei loro miti dove racconta dello storico Étienne Pasquier che, a metà del '600 ['500], correda per la prima volta una ricerca storica di note a pié di pagina. I suoi contemporanei non comprendono 
la funzione di tali note e sostengono che le note sono inutili perché convinti che l'unica misura di autorità di un testo siano il tempo stesso e la fama, e che le note siano scorciatoie per forzare il giudizio dei lettori. Questo perché a quei tempi ancora ci si aspettava da un'opera storica quello che oggi ci si aspetta da un romanzo. Ma quando gli storici iniziarono ad operare all'interno di un ambiente accademico e a rivolgersi ad altri accademici che possono andare a controllare le fonti e gli archivi, allora divenne pratica comune inserire note.

Io credo che, con il romanzo, siamo arrivati ad un momento simile cioè esiste un cambiamento nel pubblico che ora, tramite internet, è in grado di controllare e accedere ad archivi digitali in modo prima impensabile. Da qui, l'esigenza di dare al lettore la possibilità di partecipare alla ricerca effettuata dall'autore. Quindi tornando al punto precedente, una narrazione che voglia aumentare la consapevolezza deve fare i conti con questo cambiamento del lettore e degli strumenti che il lettore ha a disposizione, utilizzare e vivere questo cambiamento, altrimenti non sta al passo con i tempi e con i lettori.

\section{Hai qualcosa da aggiungere a questa intervista?}

Si potrebbe aggiungere che di Previsioni del tempo è stata fatta anche una piccola versione teatrale da parte della Compagnia Fantasma che l'hanno reinterpretata in chiave di dialogo teatrale e musicale. Inoltre, Previsioni del tempo è stata la prima occasione in cui noi abbiamo scritto su commissione. Questo è interessante perché spesso lo scrivere su commissione viene visto come una limitazione della creatività dell'autore e derubricato a "fare marchette". Però in questo caso la commissione non è stata fatta a caso perché Edizioni Ambiente ha scelto autori che, in qualche modo, avevano questa tematica nel loro carniere e che la potevano tirare fuori non in maniera impacciata o posticcia e, d'altra parte, per quanto avessimo delle perplessità iniziali, è stato un modo per capire che, a volte, la commissione può essere l'occasione per affrontare una tematica rispetto alla quale non ti eri occupato a fondo. Lavorare per Edizioni Ambiente è stato interessante perché, alla fine, è stato un modo per ragionare sulla creatività applicata alla narrazione in un settore piuttosto specifico. 


\section{Acknowledgments}

I extend boundless gratitude to all living beings: without their concerted efforts, this thesis would have been impossible.

Here, I can name but a few individuals who spring to mind. Myself, for a journey of thousand miles begins with a single step. My parents, for their imperfect but unconditional love. My brother. My dharma teachers and friends. Victoria University of Wellington, for funding my ideas. My thesis supervisors, Dr. Sally Hill and Dr. Claudia Bernardi, for their patience and their insight. My friend Shun Cheung, for being there. My friend Dr. Steeve Mercier, for encouraging me to start this project. The riroriro's song, the tui's chatter, and the $k a k a$ 's exclamations. The fern's fractally folded fiddlehead. Those who have crossed my path, and those who did not. My enemies.

You all made this possible. Thank you. 


\section{Works Cited}

Abram, David. Becoming Animal: An Earthly Cosmology. Vintage Books, 2011. Web. Vintage Series.

Ackerman, Frank, et al. "Did the Stern Review underestimate US and global climate damages?" Energy Policy 37.7 (2009): 2717-2721. Web.

Adebayo, A. and A. S. Dada. "An Evaluation of the causes of oil pipeline incidents In Oil and Gas Industries in Niger Delta Region of Nigeria." Journal of Engineering and Applied Sciences 3.3 (2008): 279-281. Print.

Aitken, Christopher, Ralph Chapman, and John McClure. "Climate change, powerlessness and the commons dilemma: Assessing New Zealanders' preparedness to act." Global Environmental Change 21.2 (2011): 752-760. Web. Ajugwo, Anslem O. "Negative effects of gas flaring: The Nigerian Experience." Journal of Environment Pollution and Human Health 1.1 (2013): 6-8. Web.

Alaimo, Stacy. Bodily Natures: Science, Environment, and the Material Self. Indiana University Press, 2010. Print.

Alcott, Blake. "Impact Caps: Why Population, Affluence and Technology Strategies Should Be Abandoned." Journal of Cleaner Production 18.6 (Apr. 2010): 552-560. Web.

—_."Jevons' paradox." Ecological economics 54.1 (2005): 9-21. Print.

Alighieri, Dante. The Divine Comedy: Inferno: Text and Commentary. Trans. Charles S. Singleton. 2 vols. Princeton University Press, 1977. Web. Bollingen series. Alighieri, Dante and Ettore Zolesi. La Divina Commedia. Inferno. Armando Editore, 2002. Web. 
Amnesty International. Nigeria: Petroleum, Pollution and Poverty in the Niger Delta. Ed. Amnesty International. Amnesty International, 2009. Web. 08 June 2009. Andreetto, Jadel. "Personal interview." Bologna. 13 November 2013. Print. "Anthropocentric." Oxford English Dictionary. 2013. Web. 18 Sept. 2013.

Antunes, Ricardo, et al. "Individually distinctive acoustic features in sperm whale codas." Animal Behaviour 81.4 (2011): 723-730. Print.

Archer, David. "Irreversible Does Not Mean Unstoppable." realclimate.org. 01 Feb. 2009. Web.

Asante, Kwadwo Ansong, et al. "Multi-trace element levels and arsenic speciation in urine of e-waste recycling workers from Agbogbloshie, Accra in Ghana." Science of the Total Environment 424 (27 Feb. 2012): 63-73. Print.

Ashton, Paul W. From the Brink: Experiences of the Void from a Depth Psychology Perspective. Karnac, 2007. Web.

Augé, Marc. Non-places: Introduction to an Anthropology of Supermodernity. Verso, 1995. Web Cultural Studies.

Avgeropoulos, Yorgos, dir. Delta, Oil's Dirty Business. 2007. Small Planet Productions, 2007. Film.

Barnes, David K. A., Adam Walters, and Leandra Gonçalves. "Macroplastics at sea around Antarctica." Marine Environmental Research 70.2 (2010): 250-252. Print.

Baroni, Luciana, et al. "Evaluating the environmental impact of various dietary patterns combined with different food production systems." European Journal of Clinical Nutrition 61.2 (2006): 279-286. Print.

Barron, Patrick and Anna Re. Italian Environmental Literature: An Anthology. Italica Press, 2003. Print.

Bass, Steve. "Planetary boundaries: Keep off the grass." Nature (10 Sept. 2009): 113-114. Web. 16 Jan. 2013.

Batson, C. Daniel, et al. "Empathy, attitudes, and action: Can feeling for a member of a stigmatized group motivate one to help the group?" Personality and Social Psychology Bulletin 28.12 (2002): 1656-1666. Print. 
Beetz, Becky. "Deutsche Bank: Sustainable solar market expected in 2014." PV Magazine. 26 Feb. 2013. Web. 04 Mar. 2013.

Belfiore, E.S. Tragic Pleasures: Aristotle on Plot and Emotion. Princeton University Press, 1992. Print.

Benayoun, Robert. "The King is Naked." The New Wave: Critical Landmarks. Ed. Peter Graham. 1968. Print.

Bennett, H. Stanley, et al. "President's Science Advisory Committee (PSAC):

Pesticides report, 15 May 1963." JFK Library. Washington D.C.15 Apr. 1963.

Web. 06 Mar. 2013.

Bennett, Jane. Vibrant Matter: A Political Ecology of Things. Duke University Press, 2009. Web. a John Hope Franklin Center Book.

Berns, Gregory S., et al. "Short- and long-term effects of a novel on connectivity in the brain." Brain connectivity (2013). Print.

Biancofiore, Angela. “Intervista a Laura Pugno." Montpellier. Print.

Bigaroni, Marino, ed. Compilatio assisiensis. 1975. Web.

Bolelli, Lorella. "Giù le mani dal verde d'Emilia." Il Resto del Carlino (18 Sept. 2007). Web. 27 Nov. 2012.

Boscolo, Claudia. "The idea of epic and New Italian Epic." Journal of Romance Studies 10 (1 2010): 19-35. Print.

Breuer, Joseph and Sigmund Freud. Studies On Hysteria. Basic Books, 2009. Print. Brown, Simon. "The new deficit model." Nature: Nanotechnology 4.10 (2009): 609_ 611. Print.

Buell, Lawrence. "Ecocriticism: some emerging trends." Qui Parle: Critical Humanities and Social Sciences 19.2 (2011): 87-115. Print.

Bullard, Robert D. Unequal Protection: Environmental Justice and Communities of Color. Random House (NY), 1994. Print.

BusinessGreen. "Windfarms break energy record in Spain." the Guardian 04 Jan. 2013. Web 04 Mar. 2013.

Calabria, Esmeralda and Andrea D’Ambrosio, dir. Biùtiful cauntri. 2008. Indipendenti Regionali, 2008. Film. 
Calvino, Italo. Difficult Loves. Trans. William Weaver. London: Secker \& Warburg, 1983. Print. Trans. of La speculazione edilizia.

—.Invisible Cities. Trans. William Weaver. London: Random House Group, 1997. Print.

—.La speculazione edilizia. Torino: Einaudi, 1978. Print.

—.La speculazione edilizia. Mondadori, 2013. Web.

- Le città invisibili. Einaudi, 1972. Print.

-.Le cosmicomiche. Einaudi, 1965. Print.

-.Marcovaldo: Ovvero, le stagioni in città. Einaudi, 1980. Print.

Carlowicz, Michael and Rebecca Lindsey. "The World We Avoided by Protecting the Ozone Layer." 13 May 2009. Web.

Carroll, Joseph. Literary Darwinism: Evolution, Human Nature, and Literature. Routledge, 05 Feb. 2004. Print.

Carson, Rachel. Silent spring. 40th anniversary ed. Boston: Houghton Mifflin, 2002. Print.

Cederna, Antonio. I vandali in casa. Laterza, 2007. Print. I Robinson.

- _."Parco Nazionale d'Abruzzo: Una crosta edilizia sta ricoprendo una delle zone più suggestive d'Europa. L'hanno svenduto al peggiore offerente." Il Giorno (28 Apr. 1965). Web.

Celati, Gianni. Narratori delle pianure. Feltrinelli Editore, 1988. Print.

-Quattro novelle sulle apparenze. Feltrinelli Editore, 2002. Print.

—.Verso la foce. Feltrinelli Editore, 1992. Print.

Chiesi, Roberto. "Pasolini ambientalista." Pasolini.net (Sept. 2005). Web. 15 Mar. 2013.

Chouard, Tanguy. "Revenge of the hopeful monster." Nature 463.7283 (2010): 864-867. Print.

Claudianus. In Rufinum. Trans. Maurice Platnauer. Loeb Classical Library, 1922. Print.

CNN Money. "Fortune Global 500." 2013. Web.

Cohen, Stanley. States of Denial: Knowing about Atrocities and Suffering. Polity Cambridge, 2001. Print. 
Colombelli-Négrel, Diane, et al. "Embryonic learning of vocal passwords in superb fairy-wrens reveals intruder cuckoo nestlings." Current Biology 22.22 (2012): 2155-2160. Print.

Conrad, Joseph. Cuore di tenebra. Fidenza (PR): Mattioli 1885, 2007. Print.

- Heart of Darkness. Planet eBook, 1902. Web.

- - Heart of Darkness; The Secret Sharer. Signet Classic, 1997. Web. Signet Classics Series.

Conti, Laura. Una lepre con la faccia di bambina. Editori Riuniti, 1978. Print.

Coppola, Francis F., dir. Apocalypse Now Redux. 1979. Zoetrope Studios. Film.

Coppola, Francis F., dir. The Godfather. 1972. Paramount Pictures. Film.

Corpo Forestale dello Stato. Incendi boschivi 2008. Corpo Forestale dello Stato, 2009. Web,

-.Incendi boschivi 2009. Corpo Forestale dello Stato, 2010. Web.

-.Incendi boschivi 2010. Corpo Forestale dello Stato, 2011. Web.

-.Incendi boschivi 2010 - Tabelle e mappe regionali. Corpo Forestale dello Stato, 2010. Web.

—.Incendi boschivi 2011. Corpo Forestale dello Stato, 2012. Web.

-.Incendi boschivi 2012. Corpo Forestale dello Stato, 2013. Web.

Corsale, Ivana, dir. Campania In-Felix. 2011. BUR. Film.

Creative Commons. "Attribution-NonCommercial-ShareAlike 3.0 Unported." 2013. Web.

Crutzen, Paul J. "Albedo enhancement by stratospheric sulfur injections: A contribution to resolve a policy dilemma?" Climatic change 77.3 (2006): 211220. Print.

Cutforth, Nancy B. "The effect of group bibliotherapy in reducing the anxieties of children in grades one, two and three." PhD. ProQuest Dissertations \& Theses Full Text, 1980. Print.

De Cataldo, Giancarlo. Fuoco! Edizioni Ambiente, 2007. Print.

-.Nelle mani giuste. Einaudi, 2010. Print. Super ET.

-.Romanzo criminale. Einaudi, 2010. Print. 
De Luca, Stefano. "Il movimento ecologista." inStoria - rivista online di storia \& informazione. instoria.it. May 2007. Web. 04 Mar. 2013.

De Palma, Brian, dir. Scarface. 1983. Martin Bregman. Film.

De Sica, Vittorio, dir. Il tetto. 1955. Titanus. FLV.

Del Porto, Dario. "Si pente Iovine, superboss di Gomorra." la Repubblica (22 May 2014). Web.

Della Seta, Roberto. La Difesa dell'ambiente in Italia: Storia e cultura del movimento ecologista. FrancoAngeli, 2000. Print.

Dick, Philip K. The Man in the High Castle. Penguin Books Limited, 2012. Web

Doley, Rebekah. "Pyromania Fact or Fiction?" British journal of criminology 43.4 (2003): 797-807. Print.

“Doubt Is Our Product Memo." Web.

Douglass, Anne R., Paul A. Newman, and Susan Solomon. "The Antarctic ozone hole: An update." Phys. Today 67.7 (June 2014): 42-48. Web.

Duckworth, Angela L. and Martin E. P. Seligman. "Self-discipline outdoes IQ in predicting academic performance of adolescents." Psychological science 16.12 (2005): 939-944. Print.

Easterlin, Nancy. “Cognitive Ecocriticism: Human Wayfinding, Sociality, and Literary Interpretation." Introduction to Cognitive Cultural Studies. 2010. 257274. Print.

Eco, Umberto. "On some functions of literature." Trans. Martin McLaughlin. The Yale Review 92 (4 2004): 1-13. Web. 25 Mar. 2013.

"Ecomafia." Dizionario Treccani. 2013. Web. 10 July 2013.

Engwegbara, Basil. “Toxic Colonialism.” The Tech 121 (16 06 Apr. 2001): 7. Web. 10 July 2013.

Eni's Board of Directors. "Relazione sul governo societario e gli assetti proprietari." (2010): 45. Web

"Epica." Dizionario Treccani. 2013. Web 10 July 2013.

European Commission. “European Waste Catalogue." (03 May 2000). Web

Eurostat. "Land covered by artificial." 25 Oct. 2013. Web.

—_."Population density." 24 June 2014. Web. 
Evangelisti, Valerio. “Literary Opera. Evangelisti e Lucarelli sul New Italian Epic." 06 May 2008. Web.

Falcucci, Alessandra, Luigi Maiorano, and Luigi Boitani. "Changes in landuse/land-cover patterns in Italy and their implications for biodiversity conservation." Landscape Ecology 22 (4 2007): 617-631. Print.

Feshbach, Norma D. "Studies of Empathic Behavior in Children." Progress in experimental personality research. Vol. 8. Academic Press, 1978. Print.

Flannery, Tim. The Weather Makers: The History \& Future Impact of Climate Change. Text Publishing Company, 2010. Print.

Fournier, Valérie. "Escaping from the economy: The politics of degrowth." International Journal of Sociology and Social Policy 28 (11/12 24 Sept. 2008): 528545. Web. 28 Feb. 2013.

Fraschini, Paola. "Un tema scottante: Intervista a Giancarlo De Cataldo." Puntosostenibile: La newsletter di Edizioni Ambiente 11 (Nov. 2007). Web.

Frazer, James G. Il ramo d'oro: Studio sulla magia e sulla religione. Newton Compton, 2006. Print.

Freud, Sigmund. The Uncanny. Penguin, 2003. Print. Trans. of Das Unheimliche. 1919.

Frynas, Jedrzej G. "Legal change in Africa: Evidence from oil-related litigation in Nigeria." Journal of African Law 43.2 (1999): 121-150. Print.

"Furor on Memo At World Bank." New York Times (1992). Web.

Gaard, Greta, Simon C. Estok, and Serpil Oppermann, eds. International

Perspectives in Feminist Ecocriticism. Taylor and Francis, 07 June 2013. Print. Routledge Interdisciplinary Perspectives on Literature.

Galbraith, John K. Economics, Peace and Laughter. New American Library, 1981. Web. Meridian books.

Gardiner, Stephen M. “A perfect moral storm: Climate change, intergenerational ethics and the problem of moral corruption." Environmental Values (2006): 397-413. Print.

Geller, Howard. Energy Revolution: Policies for a Sustainable Future. Island Press, 2002. Print. 
Geller, Jeffrey L., Melissa McDermeit, and Julie-Marie Brown. "Pyromania? What does it mean?" Abstract. Journal of forensic sciences 42 (1997): 1052-1057. Print.

Genna, Giuseppe. Grande Madre Rossa. Mondadori, 2004. Print.

Geraci, Angela. "Fermiamo il cemento: uccide la nostra felicità." City. 26 Oct. 2007. Web, 27 Nov. 2012.

Gitz, Vincent and Philippe Ciais. "Future expansion of agriculture and pasture acts to amplify atmospheric $\mathrm{CO} 2$ levels in response to fossil-fuel and land-use change emissions." Climatic Change 67.2-3 (2004): 161-184. Web.

Glotfelty, Cheryll. "What is Ecocriticism." Asle Online: The Association for the Study of Literature and Environment (1994). Print.

Gould, Niles and Stephen J. Eldredge. "Punctuated equilibria: An alternative to phyletic gradualism." 1972. Essential Readings in Evolutionary Biology (2014): 239. Print.

Graziano, Gian Vito. “Abusivismo e legalità." June 2013. Web

Gross, Linda B. "A study of the relationship between selected oral readings in sex-role oriented children's literature and the personal and social adjustment of the self-concept of children in Grades one and three." PhD. ProQuest Information \& Learning, 1978. Print.

Gruber, Nicolas and James N. Galloway. "An Earth-system perspective of the global nitrogen cycle." Nature 451 (7176 2008): 293-296. Web. 28 Feb. 2013.

Gugliotta, Agata. Nigeria, risorse di chi? Petrolio e gas nel delta del Niger. Odoya, 2008. Print.

Hakemulder, Jèmeljan. The Moral Laboratory: Experiments Examining the Effects of Reading Literature on Social Perception and Moral Self-concept. John Benjamins Publishing, 2000. Print.

Hamilton, Clive. Earthmasters: Playing God with the Climate. Allen \& Unwin, 2013. Web.

-.Requiem for a Species. Routledge, 2011. Print.

Hamilton, Clive and Tim Kasser. "Psychological adaptation to the threats and stresses of a four degree world." Four degrees and beyond (2009). Web. 
Hamner, Robert D. Joseph Conrad: Third World Perspectives. Three Continents Press, 1990. Web. Critical Perspectives Series.

Hancock, Jeff and Michael Woodworth. "An 'Eye' for an 'I': The Challenges and Opportunities for Spotting Credibility in a Digital World." Applied Issues in Investigative Interviewing, Eyewitness Memory, and Credibility Assessment. Ed. Marguerite Ternes Barry S. Cooper, Dorothee Griesel. Springer, 2013. 325-340. Print.

Hansen, James, et al. "Earth's energy imbalance: Confirmation and implications." Science 308.5727 (2005): 1431-1435. Print.

Hansen, James, et al. "Target atmospheric CO2: Where should humanity aim?" The Open Atmospheric Science Journal 2 (15 Oct. 2008): 217-231. Print.

Haq, Husna. "Climate change inspires a new literary genre: cli-fi." The Christian Science Monitor (16 Apr. 2013). Web.

Harris, Robert. Pompeii. Arrow, 2004. Web. Arrow Books.

Harvey, Brian K. "What is a Hacker?" 1985. Web.

Harvey, Fiona. “World's poorest will feel brunt of climate change, warns World Bank." the Guardian 19 June 2013. Web.

Hawthorne, Nathaniel. The Centenary Edition of the Works of Nathaniel Hawthorne. Ed. William Charvat, et al. Ohio State University Press, 1963. Print. The Centenary Edition of the Works of Nathaniel Hawthorne v. 8.

Heath, Chip and Dan Heath. Made to Stick: Why Some Ideas Survive and Others Die. Random House, 2007. Print.

"Heimlich." Oxford German-English Dictionary. 17 Dec. 2014. Web. 17 Dec. 2014. Heine, Steven and Dōgen. The Zen Poetry of Dōgen. Tuttle Publishing, 1997. Print. Hekman, Susan. The Material of Knowledge: Feminist Disclosures. Indiana University Press, 2010. Web. The Material of Knowledge. Herrigel, Eugen. “The Knightly Art of Archery.” 1936. Trans. Charles Harper Lutgard Cunningham. Japanologie (2003): 193-212. Print. Hochschild, Adam. King Leopold's Ghost: A Story of Greed, Terror, and Heroism in Colonial Africa. Houghton Mifflin Harcourt, 1999. Web. 
Holifield, Ryan. "Defining environmental justice and environmental racism." Urban Geography 22.1 (2001): 78-90. Print.

Howden, Daniel. "Shell may pull out of Niger Delta after 17 die in boat raid." The Independent (16 Jan. 2006). Web.

Huesemann, Michael and Joyce Huesemann. Techno-Fix: Why Technology Won't Save Us Or the Environment. New Society Publishers, 2011. Web.

Hume, David. A Treatise on Human Nature: Being an Attempt to Introduce the Experimental Method of Reasoning Into Moral Subjects; and Dialogues Concerning Natural Religion. Ed. T. H. Green and T.H. Grose. Longmans, Green and Company, 1874. Web. A Treatise on Human Nature: Being an Attempt to Introduce the Experimental Method of Reasoning Into Moral Subjects; and Dialogues Concerning Natural Religion 2.

Huo, Xia, et al. "Elevated blood lead levels of children in Guiyu, an electronic waste recycling town in China." Environmental Health Perspectives 115.7 (28 July 2007): 1113. Print.

Inman, Mason. "Carbon is forever." Nature Reports Climate Change 0812 (Dec. 2008): 156-158. Web.

Intergovernmental Panel on Climate Change. "Climate Change 2001: Synthesis Report." 2001. Web.

-.."Projected climate change and its impacts." IPCC Fourth Assessment Report: Climate Change 2007 (2007). Web. 05 Apr. 2013.

Iovino, Serenella. "Ecocriticism, cultural evolutionism, and ecologies of mind." Cosmo. Comparative Studies in Modernism (2013): 113-126. Print.

—_."Ecocriticism, Ecology of Mind, and Narrative Ethics: A Theoretical Ground for Ecocriticism as Educational Practice." Interdisciplinary Studies in Literature and Environment 17.4 (2010): 759. Print.

-.Ecologia letteraria: Una strategia di sopravvivenza. Edizioni Ambiente, 2006. Print.

- . "Material Ecocriticism: Matter, Text, and Posthuman Ethics." Ecology, Ethics: Recent Trends in European Ecocriticism (2013). Print. 
- . "Naples 2008, or, the Waste Land: Trash, Citizenship, and an Ethic of Narration." Neohelicon 36 (2 Sept. 2009): 335-346. Web.

-_."Quanto scommettiamo? Ecologia letteraria, educazione ambientale e 'Le cosmicomiche' di Italo Calvino." Compar(a)ison 2 (2007 2007). Print.

- . “The Wilderness of the Human Other: Italo Calvino's 'The Watcher' and a Reflection on the Future of Ecocriticism." The Future of Ecocriticism. Ed. Nevin Özkan Serpil Oppermann, Ufuk Özdağ and Scott Slovic. 2012. Print.

Iovino, Serenella and Serpil Oppermann, eds. Material Ecocriticism. Indiana University Press, 2014. Print.

Istituto nazionale di statistica. "Popolazione residente totale e popolazione residente dei centri abitati dei grandi comuni ai censimenti 1861-2001 e anno 2009 (ai confini dell'epoca)." 31 Dec. 2009. Web.

Istituto nazionale per l'assicurazione contro gli infortuni sul lavoro.

"Costruzioni: Calano le denunce ma gli infortuni restano gravi." Andamento degli infortuni sul lavoro 12 (Dec. 2011). Web.

-.Rapporto Annuale 2011: Parte quarta/statistiche: Infortuni e malattie professionali. Istituto nazionale per l'assicurazione contro gli infortuni sul lavoro, July 2012. Web.

Jackson, Tony E. "'Literary Interpretation' and cognitive literary studies." Poetics Today 24.2 (2003): 191-205. Print.

Jamieson, Dale. "Ethics and intentional climate change." Climatic Change 33.3 (1996): 323-336. Print.

Jha, Alok. "Astronomer royal calls for 'Plan B' to prevent runaway climate change." the Guardian 11 Sept. 2013. Web. 13 Sept. 2013.

Joughin, Ian, Benjamin E. Smith, and Brooke Medley. "Marine Ice Sheet Collapse Potentially Under Way for the Thwaites Glacier Basin, West Antarctica." Science 344.6185 (May 2014): 735-738. Web.

Judson, Olivia. "The Monster Is Back, and It's Hopeful." The New York Times (22 Jan. 2008). Web.

Kai Zen. Delta blues. senzablackjack, 2010. Web.

—.La strategia dell'ariete. senzablackjack, 2007. Web. 
Kaplan, David E. and A. Dubro. Yakuza: Japan's Criminal Underworld. University of California Press, 2012. Print.

Keen, Suzanne. Empathy and the Novel. Oxford; New York: Oxford University Press, 2007. Print.

Kellert, Stephen H. In the Wake of Chaos: Unpredictable Order in Dynamical Systems. University of Chicago Press, 1994. Print.

Kellstedt, Paul M., Sammy Zahran, and Arnold Vedlitz. "Personal efficacy, the information environment, and attitudes toward global warming and climate change in the United States." Risk Analysis 28.1 (2008): 113-126. Print.

Kendrick, Keith. "'Getting to know you': How do animals recognise each other and us?" Barnard's Inn Hall, Gresham College, 20 Feb. 2003. Web.

Kidd, David C. and Emanuele Castano. "Reading literary fiction improves theory of mind." Science 342.6156 (2013): 377-380. Print.

Kingsolver, Barbara. Flight Behavior. HarperCollins Canada, Limited, 2013. Web.

Kriegler, Elmar, et al. "Imprecise probability assessment of tipping points in the climate system." Proceedings of the National Academy of Sciences 106.13 (2009): 5041-5046. Web.

Krznaric, Roman. "Proposal for a revolution of human relationships." Future Ethics: Climate Change and Apocalyptic Imagination (14 Sept. 2010): 153-172. Print.

Lakoff, George. "The contemporary theory of metaphor." Metaphor and thought. Vol. 2. Cambridge, 1993. 202-251. Print.

"Lameness." Oxford English Dictionary. 2015. Web. 13 Jan. 2015.

Latour, Bruno. "Why has critique run out of steam? From matters of fact to matters of concern." Critical inquiry 30.2 (2004): 225-248. Print.

Lear, Linda J. "Rachel Carson's Silent Spring." Environmental History Review 17 (2 01 June 1993): 23-48. Web. 05 Mar. 2013.

Legambiente. "Perché un ambientalismo scientifico." Legambiente. 15 Nov. 2010. Web. 05 Mar. 2013.

—. “Rifiuti S.p.A. Radiografia dei traffici illeciti.” Web. 
Legambiente and Dipartimento Nazionale della Protezione Civile. Ecosistema incendi 2011: Monitoraggio sulle azioni dei Comuni italiani nell'applicazione della legge 353/2000 e nella mitigazione del rischio incendi boschivi. Legambiente, Sept. 2011. Print.

Legislation and Military Operations Subcommittee and Committee on Government Operations. Energy Reorganization Act of 1973: Hearings, Ninetythird Congress, First Session, on H.R. 11510. U.S. Government Printing Office, 1973. Web.

Lehr, Fran. "Bibliotherapy." Journal of Reading 1 (25 1981): 76-79. Print.

Lemish, Dafna. The Routledge International Handbook of Children, Adolescents, and Media. Taylor \& Francis, 2013. Print.

Leopardi, Giacomo. “Dialogo della Natura e di un islandese." 1918. Web.

Leopold, Aldo. Round River: A Parable. Oxford University Press, 1972. Print.

Lichtman, Flora and Barbara Kingsolver. "Climate Change Takes Flight in New Novel." npr (09 Nov. 2012). Web.

Louv, Richard. Last Child in the Woods: Saving Our Children from Nature-Deficit Disorder. Algonquin Books of Chapel Hill, 22 Mar. 2008. Print.

Lowenstein, Ludwig F. “Recent research into arson (1992-2000): Incidence, causes and associated features, predictions, comparative studies and prevention and treatment." Psychiatry, Psychology and Law 10.1 (2003): 192-198. Web. 04 Mar. 2011.

Lucarini, Loredana. Una storia ecologica. Franco Angeli, 1998. Print.

Lucas, Frank L. Tragedy in Relation to Aristotle's 'Poetics'. Hogarth Press, 1939.

Print. Hogarth lectures on literature. [no. 2].

Luntz, Frank. "The Environment: A Cleaner, Safer, Healthier America." Web.

Lupo, Salvatore. Storia della mafia: Dalle origini ai giorni nostri. Donzelli editore, 2004. Print.

Luther Blissett. Q. Wu Ming Foundation, 1999. Web.

Lynas, Mark. Six Degrees: Our Future on a Hotter Planet. Fourth Estate, 2007. Print. Macchiavelli, Loriano. Sequenze di memoria. Einaudi, 2011. Print.

Macfarlane, Robert. "The burning question." the Guardian (24 Sept. 2005). Web 
MacKay, David. Sustainable Energy - Without the Hot Air. UIT Cambridge, 2008. Web.

Magnússon, E. and W. Morris. Völsunga Saga: The Story of the Volsungs \& Niblungs, with Certain Songs from the Elder Edda. F.S. Ellis, 1870. Print.

Maller, Cecily, et al. "Healthy nature healthy people: 'Contact with nature' as an upstream health promotion intervention for populations." Health promotion international 21.1 (2006): 45-54. Print.

Margono, Belinda A., et al. "Primary forest cover loss in Indonesia over 20002012." Nature: Climate Change (2014). Web.

Marino, Giovanni. "Quando quel boss mi disse: per noi la monnezza è oro." la Repubblica (06 Jan. 2008). Web. 18 Sept. 2012.

Marshall, George. Don't Even Think about It: Why Our Brains Are Wired to Ignore Climate Change. Bloomsbury, 2014. Print.

Mattioli, Gianni and Massimo Scalia. "Prometeo è caduto a Cernobyl." Il Manifesto (Apr. 1986). Print.

McCaffery, Larry. "An interview with David Foster Wallace." Review of Contemporary Fiction 13.2 (1993): 127. Print.

McClaskey, Harris C. "Bibliotherapy with emotionally disturbed patients: An experimental study." PhD. ProQuest Information \& Learning, 1971. Print.

McCright, Aaron M. and Riley E. Dunlap. "Anti-reflexivity: The American conservative movement's success in undermining climate science and policy." Theory, Culture \& Society 27.2-3 (2010): 100-133. Print.

McKeon, Richard, ed. The Basic Works of Aristotle. Random House Publishing Group, 2009. Print.

McKibben, Bill. Eaarth: Making a Life on a Tough New Planet. Henry Holt and Company, 13 Mar. 2010. Print.

McLaughlin, Martin L. “Calvino's Visible Cities." Romance Studies 11.2 (1993): 67-82. Web.

- ."The genesis of Calvino's La speculazione edilizia." Italian Studies 48 (1 01 Jan. 1993): 71-85. Print. 
Meeker, Joseph W. The Comedy of Survival: Literary Ecology and a Play Ethic. Tucson: The University of Arizona Press, 1997. Print.

Miller, Steve. "Public understanding of science at the crossroads." Public Understanding of Science 10.1 (2001): 115-120. Web.

Ministero dell'Interno. "Archivio storico delle elezioni." Archivio storico delle elezioni - Consultazione dati (1988). Web. 07 Mar. 2013.

Mischel, Harriet N. and Walter Mischel. "The development of children's knowledge of self-control strategies." Child Development (1983): 603-619. Print.

"Modifiche alla legge sull'ordinamento penintenziario e sulla esecuzione delle misure privative e limitative della della libertà." La Gazzetta Ufficiale 241 (16 Oct. 1986). Web

Monbiot, George. "An Ounce of Hope is Worth a Ton of Despair." 16 June 2014. Web.

—."Toxic Assets." 22 Sept. 2009. Web.

Montrucchio, Alessandra. Cardiofitness. Toby Press LLC, 1999. Web.

-.E poi la sete. Marsilio, 2011. EPUB file.

-Fuoco, vento, alcol. Marsilio, 2006. Web Romanzi e racconti.

- Macchie rosse. Marsilio, 2001. Web

Mori, Masahiro, Karl F. MacDorman, and Norri Kageki. “The uncanny valley [from the field]." Robotics \& Automation Magazine, IEEE 19.2 (2012): 98-100. Print.

“Morire di rifiuti." la Repubblica (06 June 2007). Web.

Morton, Timothy. Hyperobjects: Philosophy and Ecology After the End of the World. University of Minnesota Press, 2013. Print.

Myers, Norman, et al. "Biodiversity hotspots for conservation priorities." Nature 403.6772 (2000): 853-858. Print.

National Snow and Ice Data Center. "Arctic sea ice falls to third-lowest extent; downward trend persists." 10 Apr. 2010. Web.

Nebbia, Giorgio. Il punto di vista cristiano sull'ecologia. Italia Nostra, 1972. Print.

Newman, Paul A. “Ozone Hole Watch.” 25 Sept. 2013. Web. 
Nicholls, Robert J., et al. "Sea-level rise and its possible impacts given a 'beyond $4 \mathrm{C}$ world' in the twenty-first century." Philosophical transactions of the Royal Society A: Mathematical, physical and engineering sciences 369.1934 (2011): 161181. Print.

Nixon, Rob. Slow Violence. Harvard University Press, 2011. Web.

Öhman, Arne and Susan Mineka. "The malicious serpent snakes as a protypical stimulus for an evolved module of fear." Current Directions in Psychological Science 12.1 (2003): 5-9. Print.

Oreskes, Naomi and Erik M. Conway. Merchants of Doubt: How a Handful of Scientists Obscured the Truth on Issues from Tobacco Smoke to Global Warming. Bloomsbury, 2010. Print.

Orlowski, Jeff, dir. Chasing Ice. Adapt. Mark Monroe. Perf. Svavar Jónatansson Louie Psihoyos, James Balog. 2012. Exposure. Film.

Orwell, George. Nineteen Eighty-four. Martin Secker and Warburg, 1949. David Campbell, 1992. Print.

Osservatorio Ambiente e Legalità. Ecomafia 2005: Le storie e i numeri della criminalità ambientale. Edizioni Ambiente, 2005. Print.

-.Ecomafia 2010: Le storie e i numeri della criminalità ambientale. Edizioni Ambiente, 2010. Print.

-.Ecomafia 2011: Le storie e i numeri della criminalità ambientale. Edizioni Ambiente, 2011. Print.

-.Ecomafia 2012: Le storie e i numeri della criminalità ambientale. Edizioni Ambiente, 2012. Print.

-.Ecomafia 2013: Le storie e i numeri della criminalità ambientale. Edizioni Ambiente, 2013. Print.

Pasolini, Pier Paolo. "Io so." Corriere della Sera (14 Nov. 1974). Web. 19 July 2013.

- Petrolio. Trans. Ann Goldstein. Pantheon Books, 1997. Print.

-.Romanzi e racconti: 1946-1961. Vol. 2. Ed. Walter Siti and Silvia De Laude. Mondadori, 2003. 1159-1830. Print.

Pérez-Peña, Richard. "College Classes Use Arts to Brace for Climate Change." (31 Mar. 2014). Web. 
Petrelli, Vanni. "Edilizia, è boom per lavoro nero e falsi lavoratori autonomi." 15 Sept. 2011. Web.

Pham, Christopher K., et al. "Marine litter distribution and density in European Seas, from the shelves to deep basins." PloS one 9.4 (2014): e95839. Print.

Pimentel, David and Marcia Pimentel. "Sustainability of meat-based and plantbased diets and the environment." The American Journal of Clinical Nutrition 78.3 (2003): 660S-663S. Print.

Pimm, Stuart L. and Peter H. Raven. "Biodiversity: Extinction by numbers." Nature 403 (6772 24 Jan. 2000): 843-845. Web. 28 Feb. 2013.

Pincio, Tommaso. Cinacittà: Memorie del mio delitto efferato. Giulio Einaudi editore, 2008. Print.

Plumwood, Val. "Androcentrism and anthrocentrism: Parallels and politics." Ethics and the Environment (1996): 119-152. Print.

Poe, Nathan. "Poe's Law." 10 Aug. 2005. Web.

Presentazione Fuoco! De Cataldo. By Giancarlo De Cataldo. 2007. Youtube, 2007.

Web. 18 Feb. 2013.

Prüss-Üstün, Annette, et al. Safer water, better health: Costs, benefits and sustainability of interventions to protect and promote health. World Health

Organization, 2008. Web.

Pugno, Laura. "Personal interview." Rome. 18 November 2013. Print.

-.Sirene. Einaudi, 2007. Print.

Randall, Rosemary. "Loss and climate change: The cost of parallel narratives." Ecopsychology 1.3 (2009): 118-129. Print.

Raven, Peter H., ed. Nature and Human Society: The Quest for a Sustainable World. National Academies Press, 1997. Print.

Raworth, Kate. "A safe and just space for humanity." Can We Live within the Doughnut? (13 Jan. 2012): 1-24. Web. 04 Feb. 2013.

Richardson, Alan and Francis F Steen. "Literature and the cognitive revolution: An introduction." Poetics Today 23.1 (2002): 1-8. Print. 
Rios, Lorena M., et al. "Quantitation of persistent organic pollutants adsorbed on plastic debris from the Northern Pacific Gyre's 'eastern garbage patch'." Journal of Environmental Monitoring 12.12 (2010): 2226-2236. Print.

"Risky toughness." The Economist (18 Sept. 2008). Web

Rittel, Horst W.J. and Melvin M. Webber. "Dilemmas in a general theory of planning." Policy sciences 4.2 (1973): 155-169. Print.

Robock, Alan. "20 reasons why geoengineering may be a bad idea." Bulletin of the Atomic Scientists (2008). Print.

Robock, Alan, et al. "Benefits, risks, and costs of stratospheric geoengineering." Geophysical Research Letters 36.19 (2009). Web.

Rockström, Johan, et al. "A safe operating space for humanity, Planetary Boundaries." Nature 461 (7263 23 Aug. 2009): 472-475. Web. 04 Sept. 2012.

Roney, J. Matthew. “Wind Surpasses Nuclear in China." 19 Jan. 2013. Web. 05 Mar. 2013.

Rowe, David E. and Robert J. Schulmann. Einstein on Politics: His Private Thoughts And Public Stands on Nationalism, Zionism, War, Peace, and The Bomb. Princeton University Press, 2007. Print.

“Ruin." Oxford English Dictionary. 10 July 2014. Web. 10 July 2014.

Sageman, Marc. Understanding Terror Networks. University of Pennsylvania Press, Inc., 2004. Web.

Sala, Osvaldo E., et al. "Global biodiversity scenarios for the year 2100." Science 287.5459 (2000): 1770-1774. Print.

Salter, Stephen. Pseudo-random Spray Release to Measure World-wide Transfer Functions of Cloud Albedo Control. Vol. 12. 02 May 2010. 12203. Print.

Saro-Wiwa, Ken. A Month and a Day: A Detention Diary. Ed. W. Boyd. Penguin Books, 1996. Web.

—. "Without Walls: The Hanged Man - Nigeria's Shame." Channel 4.

Satolli, Anna. "A tutto cemento: Intervista a Simona Vinci." puntosostenibile. Puntosostenibile 10 (Oct. 2007). Web. 27 Nov. 2012.

Satolli, Anna and Simona Vinci. “Morire di cemento." Puntosostenibile (2007).

Web. 
Saviano, Roberto. Gomorra: Viaggio nell'impero economico e nel sogno di dominio della camorra. Mondadori, 2006. Print.

Scalia, Massimo. "Audizione del collaboratore di giustizia Carmine Schiavone." Commissione parlamentare d'inchiesta sul ciclo dei rifiuti e sulle attività ad esso connesse. Print.

Scheff, Thomas J. Catharsis in Healing, Ritual, and Drama. University of California Press, 1979. Print.

Schneider, François, Giorgos Kallis, and Joan Martinez-Alier. “Crisis or opportunity? Economic degrowth for social equity and ecological sustainability. Introduction to this special issue." Journal of Cleaner Production 18 (6 Mar. 2010): 511-518. Web. 28 Feb. 2013.

Schwartz, S. E. and P. Warneck. "Units for use in atmospheric chemistry (IUPAC Recommendations 1995)." Pure and Applied Chemistry 67.8-9 (Jan. 1995). Web.

Sciascia, Leonardo. Il giorno della civetta. Adelphi, 2011. Print.

Scurati, Antonio. La seconda mezzanotte. Bompiani, 2012. Print.

—_.."L'epica è rediviva e lotta insieme a noi: Tuttolibri." La Stampa 07 Feb. 2009. Print.

"Se l'autore entra nelle tenebre dell'ecomafia." il Giorno (2008): 34. Web.

Sears, Paul B. "Ecology ${ }^{-}$a subversive subject." BioScience 14.7 (1964): 11-13. Print.

Senior, Kathryn and Alfredo Mazza. "In Italia il 'triangolo della morte' è collegato alla crisi dei rifiuti." The Lancet Oncology 5 (2004). Print.

Skeem, Jennifer L., et al. "Psychopathic personality bridging the gap between scientific evidence and public policy." Psychological Science in the Public Interest 12.3 (2011): 95-162. Print.

Skrimshire, Stefan, ed. Future Ethics: Climate Change and Apocalyptic Imagination. 1st ed. Continuum, 2010. Print.

Snyder, Peter K., et al. "Analyzing the effects of complete tropical forest removal on the regional climate using a detailed three-dimensional energy budget: An application to Africa." Journal of Geophysical Research: Atmospheres 109.D21 (2004): 19. Web 
Solomon, Susan. Climate Change 2007: The Physical Science Basis: Working Group I Contribution to the Fourth Assessment Report of the IPCC. Cambridge University Press, 10 Aug. 2007. Print.

Sorrell, Steve. "Jevons' Paradox revisited: The evidence for backfire from improved energy efficiency." Energy Policy 37.4 (2009): 1456-1469. Print.

SOS Impresa. "Sos Impresa: 'Mafia Spa è la prima banca d'Italia'." 2012. Web.

Stafford, Emma. "Personification in Greek Religious Thought and Practice." $A$

Companion to Greek Religion. Ed. Daniel Ogden. Vol. 60. Wiley. com, 2008. 71. Print.

Stenner, Chris, Arvid Uibel, and Heidi Wittlinger, dir. Das Rad. 2003. Film Academy Baden-Württemberg. Film.

Stern, Nicholas. "The economics of climate change: the Stern review: Executive Summary (short)." The National Archives (2007). Web.

Steve Connor, Chris Green. "Climate scientists: it's time for 'Plan B'." The Independent (02 Feb. 2009). Web.

Stevens, William K. "If climate changes, it may change quickly." The New York Times (1998). Web. 12 Apr. 2013.

Stewart, Heather and Larry Elliott. "Nicholas Stern: 'I got it wrong on climate change - it's far, far worse'." the Guardian (26 Jan. 2013). Web.

Stoll-Kleemann, Susanne, Tim O'Riordan, and Carlo C. Jaeger. "The psychology of denial concerning climate mitigation measures: Evidence from Swiss focus groups." Global Environmental Change 11.2 (2001): 107-117. Web.

Suetonius. De Vita XII Caesarum. Trans. J. C. Rolfe. Loeb Classical Library, 1913. Print.

Tarantino, Quentin, dir. Kill Bill Volume 1. 2003. A Band Apart. Film.

Tavarelli, Gianluca Maria, dir. Paolo Borsellino. Adapt. Giancarlo De Cataldo, Leonardo Fasoli, and Mimmo Rafele. 2004. Taodue. Film.

The World Bank. "What We Do." 2012. Web.

Thoreau, Henry D. Walden. Houghton, Mifflin and company, 1882. Print.

Riverside Aldine series v. 1.

“To hack." Oxford English Dictionary. 2013. Web. 25 Sept. 2013. 
Tognazzi, Ricky, dir. Il caso Enzo Tortora - Dove eravamo rimasti? Adapt. Simona Izzo, Giancarlo De Cataldo, and Monica Zapelli. 2012. Fulvio Lucisano et al. Film.

Toschi, Paolo. Le origini del teatro italiano. Bollati Boringhieri, 1999. Web.

Trabace, Rossella. "Altro che piromani isolati. Puglia bruciata dal crimine:

Giancarlo de Cataldo presenta Fuoco!, storia di ecomafia per le Edizioni Ambiente." il Corriere del Mezzogiorno (11 Nov. 2007). Web.

Transcrime. "Mafia investments." 2013. Web.

Trenberth, Kevin E. and Aiguo Dai. "Effects of Mount Pinatubo volcanic eruption on the hydrological cycle as an analog of geoengineering." Geophysical Research Letters 34.15 (2007). Web.

Troisi, Licia and Paolo Barbieri. I dannati di Malva. Edizioni Ambiente, 2011. Print.

Tronko, Mykola D., et al. "A cohort study of thyroid cancer and other thyroid diseases after the Chornobyl accident: Thyroid cancer in Ukraine detected during first screening." Journal of the National Cancer Institute 98.13 (2006): 897-903. Print.

United Nations. "World Population Prospects, the 2012 Revision." 2013. Web.

United Nations Development Programme. "Niger Delta Human Development Report." Abuja: United Nations Development Programme (2006). Print.

Vallely, Paul. "Israel's mowing of Gaza's lawn is an unjust war." The Independent (10 Aug. 2014). Print.

Van Koppen, Kris and William T. Markham. Protecting Nature: Organizations and Networks in Europe and the USA. Edward Elgar Publishing, 2008. Print.

VandenBos, Gary R. and American Psychological Association. A.P.A. Dictionary of Psychology. American Psychological Association, 2007. Print.

Verderame, Michael. "The shape of ecocriticism to come." New Directions in Ecocriticism (Sept. 2010). Web.

Vinci, Simona. Come prima delle madri. Einaudi, 2003. Print. Einaudi Tascabili.

—.Dei bambini non si sa niente. Einaudi, 2009. Print. Einaudi tascabili.

—.In tutti i sensi come l'amore. Einaudi, 1999. Print. Einaudi Tascabili. 
-.Rovina. Edizioni Ambiente, 2007. Print.

Vitalis, Ordericus. Historia Ecclesiastica. c. 1142. Trans. Thomas Forester. 13 vols. Bohn, 1856. Web.

Vitousek, Peter M., et al. "Human alteration of the global nitrogen cycle: Sources and consequences." Ecological Applications 7 (3 01 July 1997): 737-750. Web. 28 Feb. 2013.

Walsh, Bryan. "Barbara Kingsolver on Flight Behavior and why climate change is part of her story." TIME Entertainment (2012). Web.

Washington, Haydn. Climate Change Denial: Heads in the Sand. Routledge, 2013. Print.

—_."The wilderness knot." PhD. University of Western Sydney, 2006. Print. Wiggins, Arthur W. The Joy of Physics. Prometheus Books, 2011. Print. Worden, James William. Grief Counseling and Grief Therapy: A Handbook for the Mental Health Practitioner. Springer Publishing Company, 2009. Print.

World Health Organisation and UNICEF. Progress on drinking water and sanitation - 2014 update. World Health Organisation, 2014. Web.

Wu Ming. 54. Wu Ming Foundation, 2002. Web.

_.."Faremo la nostra parte." Giap 4.8 (15 July 2003). Web.

- Manituana. Wu Ming Foundation, 2007. Print.

-.New Italian Epic: Letteratura, sguardo obliquo, ritorno al futuro. Einaudi, 2009. Print.

—_."Perché abbiamo rinviato l'uscita del romanzo di WM2." Giap 5.2 (18 Jan. 2004). Web.

- Previsioni del tempo. In collab. with Wu Ming. Wu Ming Foundation, 2008. Web. 11 Sept. 2012.

—. "The Perfect Storm, or rather, The Monster Interview." 14 Apr. 2007. Web. Wu Ming 1. "I posteri e il nucleare: la nostra etica puzza." 04 Oct. 2003. Web.

—. "Premessa alla versione 2.0 di New Italian Epic." Carmilla Online. Sept. 2008. Web. 01 Oct. 2012.

- Ti chiamerò Russell: romanzo totale 2002. Bacchilega Editore, 2002. Print. Collana La narrativa. 
- We're Going to Have to Be the Parents: The New Italian Epic. Ed. and trans. Wu Ming 1. 2008. Web.

Wu Ming 1 and Wu Ming 3. "Recensione di Gomorra. Viaggio nell'impero economico e nel sogno di dominio della Camorra." Giap (21 May 2006). Web. 02 Apr. 2013.

Wu Ming 2. Guerra agli umani. Wu Ming Foundation, 2004. Web.

—. "Personal interview." Bologna. 26 November 2013. Print.

Wu Ming 5. Havana glam. Wu Ming Foundation, 2003. Web.

—.."Non c'è un modo 'giusto' di produrre oggetti inutili: Limite, gioia, esperienza urbana." Giap (June 2004). Web.

WWF Italia. "La storia dei condoni in Italia." il Corriere della Sera (25 Sept. 2003). Web.

York, Richard. "Do alternative energy sources displace fossil fuels?" Nature: Climate Change 2.6 (2012): 441-443. Print.

Zehr, Stephen C. "Accounting for the Ozone Hole." The Sociological Quarterly 35.4 (1994): 603-619. Print.

Zunshine, Lisa. Why We Read Fiction: Theory of Mind and the Novel. Ohio State University Press, 2006. Print. 